Universidade de Brasília

Instituto de Ciências Exatas

Departamento de Matemática

Programa de Mestrado Profissional

em Matemática em Rede Nacional

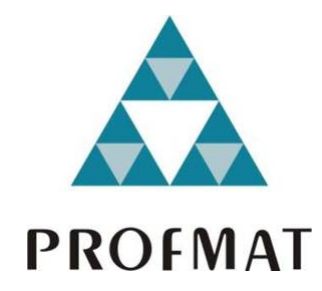

Análise da prova da primeira fase da OBMEP
como subsídio para orientar a prática docente

Regiane Quezia Gomes da Costa

Brasília

2015 

Regiane Quezia Gomes da Costa

\title{
Análise da prova da primeira fase da OBMEP como subsídio para orientar a prática docente
}

\author{
Dissertação apresentada ao Departamento \\ de Matemática da Universidade de Brasí- \\ lia, como parte dos requisitos do "Programa" \\ de Mestrado Profissional em Matemática em \\ Rede Nacional - PROFMAT, para obtenção \\ do grau de Mestre.
}

Universidade de Brasília - UnB

Departamento de Matemática - MAT

PROFMAT - SBM

Orientador: Prof. Dr. Mauro Luiz Rabelo

Brasília

2015 
Costa, Regiane Quezia Gomes da

Análise da prova da primeira fase da OBMEP como subsídio para orientar a prática docente / Regiane Quezia Gomes da Costa; orientador Mauro Luiz Rabelo. - Brasília, 2015. $212 \mathrm{p}$.

Dissertação (Mestrado - Mestrado Profissional em Matemática) - Universidade de Brasília, 2015.

1. Avaliação. 2. Distratores. 3. Engenharia de Itens. 4. Análise do Erro. 5. OBMEP. I. Rabelo, Mauro Luiz, orient. II. Título. 


\title{
Análise da prova da primeira fase da OBMEP como subsídio para orientar a prática docente
}

\author{
por \\ Regiane Quezia Gomes da Costa*
}

Dissertação apresentada ao Departamento de Matemática da Universidade de Brasília, como parte dos requisitos do "Programa" de Mestrado Profissional em Matemática em Rede Nacional - PROFMAT, para obtenção do grau de

\section{MESTRE}

Brasília, 30 de junho de 2015

Comissão Examinadora:

Prof. Dr. Mauro Luiz Rabelo - MAT/UnB (Orientador)

Prof. Dr. Kellcio Oliveira Araújo - MAT/UnB (Membro)

Prof. Dra. Erondina Barbosa da Silva - SEEDF (Membro)

* O autor foi bolsista CAPES durante a elaboração desta dissertação. 

Este trabalho é dedicado a Jesus Cristo, a meu amado filho Luís Antônio - presente de Deus e ao meu amado esposo Edson Alves, pelo inestimável carinho e apoio. 



\section{Agradecimentos}

Agradeço a Deus por me cobrir de bençãos e me ensinar a não perder as esperanças. Agradeço a minha mãe Geralda do Rosário, que me ensinou o valor do trabalho e da honestidade, e ao meu pai de coração, João Gualberto, por exigir e não me deixar desistir.

Agradeço a meus irmãos Agnaldo, Elias e Jorge por me ensinarem o valor de uma boa companhia. E desejo que Deus diminua nossas distâncias.

Agradeço a todos que contribuíram de forma atuante neste momento privilegiado de aprendizagem: João Gualberto, Euzébio, Cácio Fabrício, Ana Paula, Ronald, coordenadores da OBMEP, Maria Terezinha, gestores, professores, coordenadores da OBMEP nas escolas e alunos das escolas pesquisadas.

Agradeço a todos os professores do Departamento de Matemática da UnB que contribuíram para minha formação de docente. Agradeço aos professores: Dr. Kellcio Oliveira Araújo e Dra. Erondina Barbosa da Silva, que gentilmente aceitaram o convite para participar da banca e, em especial, ao meu orientador, Professor Dr. Mauro Luiz Rabelo, que marcou e edificou minha vida, pelo conhecimento científico e pelo exemplo de docência.

Agradecimento especial: à doce Ana Paula Vilarinho, pelo incentivo e parceria neste estudo; à guerreira Rosana de Andrade, pela amizade fiel; ao caro Kleber Xavier, pela companhia nos momentos de estudo e a todos os colegas do PROFMAT.

Agradeço, por fim, ao meu amado esposo Edson Alves, que foi o melhor pai, nos momentos que me ausentei como mãe. E ao meu filho Luís Antônio, por me esperar com o abraço mais carinhoso do mundo.

\section{Agradecimentos Institucionais}

CEBRASPE - Centro Brasileiro de Pesquisa em Avaliação e Seleção e de Promoção de Eventos

CAPES - Coordenação de Aperfeiçoamento de Pessoal de Nível Superior.

IMPA - Instituto Nacional de Matemática Pura e Aplicada.

UNB - Universidade de Brasília.

EAPE - Escola de Aperfeiçoamento dos Profissionais da Educação do DF.

SE - Secretaria de Estado de Educação do DF. 

"Quem conheceu a alegria da compreensão conquistou um amigo infalível para a vida. O pensar é para o homem, o que é o ar para os pássaros. Não toma como exemplo a cotovia quando podes ser uma águia." 



\section{Resumo}

A Olimpíada Brasileira de Matemática das Escolas Públicas (OBMEP) é uma avaliação de larga escala oferecida anualmente desde 2005 aos estudantes do ensino básico, que tem como objetivo descobrir novos talentos matemáticos e contribuir para a melhoria do ensino da matemática nessa etapa da escolaridade. Este projeto governamental inclui ações e programas que contribuem muito para o aprendizado da Matemática, principalmente para os alunos premiados. Este estudo vem contribuir para a ampliação dos objetivos deste certame, com a análise da construção do instrumento de avaliação da primeira fase do nível dois da OBMEP de 2014. O questionamento que motivou o estudo aqui apresentado foi: este instrumento de larga escala pode ser usado como subsídio de uma aprendizagem significativa? E a resposta foi investigada à luz dos pressupostos teóricos relacionados a avaliação da aprendizagem e análise do erro, a partir de uma amostra, que compreendia os alunos de cinco escolas públicas de educação básica do Distrito Federal, com o objetivo de fazer um estudo do comportamento das marcações dos estudantes. A metodologia utilizada no trabalho englobou análise de dados e conteúdo. Realizou-se uma análise dos itens da prova, a partir de resultados oriundos da aplicação da Teoria Clássica dos Testes e também das técnicas recomendadas pela Engenharia de Construção de Itens. Foi inferida e categorizada a natureza dos erros apresentados pelo grupo de estudantes pesquisado, diante da escolha dos distratores de cada questão objetiva da prova, de forma a dar suporte para uma tomada de atitude dos professores frente aos obstáculos da aprendizagem apresentados na realização das situações-problema propostas.

Palavras-chaves: Avaliação. Distratores. Engenharia de Itens. Análise do Erro. OBMEP. 



\section{Abstract}

The Brazilian Mathematical Olympiad of Public Schools - BMOPS is a large-scale government evaluation offered annually since 2005 for Students of primary education, which aims to discover young mathematical talents and contributes to the quality of education. This government project includes actions and programs in order to improve mathematical learning, especially for the awarded students. Also, this study contributes to enlarge the objectives of this evaluation process, with one analysis of the assessment's construction as the instrument of the first phase of BMOPS of 2014, in the second level. The main question that underwrote this study was: Can this large-scale's instrument be used as a subsidy for a significant learning? The answer was investigated according to theoretical assumptions related in the assessment for apprenticeship and Analysis Error, with a sample including students of five schools from Federal District, with the purpose of making one study behavior on the markings of these students. The methodology used has encompassed analysis of data and contents. One Analysis of the test items was done as well according to the Classical Theory of Tests - CTT and the techniques recommended by the Engineering Items construction. The nature of the errors of the researched students was inferred and categorized, based on the choices of the distractors presented in every question in the written test, in order to give teachers support to one decision in a problem-situation and overcome the obstacles into the learning process.

Key-words: Assessment for learning. Distractors. Engineering Items. Analysis of Error. OBMEP. 



\section{Lista de ilustrações}

Figura 1 - AGI de item bom e de item ruim, respectivamente (RODRIGUES,

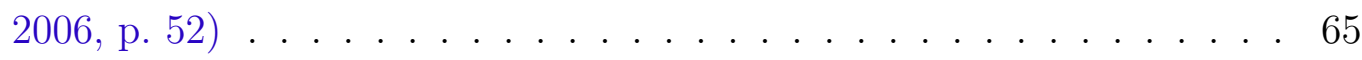

Figura 2 - AGI de item com discriminação ruim e de item difícil, respectivamente (RODRIGUES, 2006, p. 52) . . . . . . . . . . . . 66

Figura 3 - Exemplo de item convencional . . . . . . . . . . . . . 67

Figura 4 - Exemplo de item discursivo . . . . . . . . . . . . . . 70

Figura 5 - Exemplo de item de resposta curta aberta - 2a Fase da OBMEP . . . . 71

Figura 6 - Estrutura Básica do Item (adaptado de (RABELO, 2013)) . . . . . . . 73

Figura 7 - Item com exemplificação no texto-base . . . . . . . . . . . . . . 74

Figura 8 - Exemplo de item de múltipla escolha de complementação simples. . . . 75

Figura 9 - Exemplo de item de pergunta direta. . . . . . . . . . . . . . . 75

Figura 10 - Exemplo de item de múltipla escolha de interpretação. . . . . . . . . . 76

Figura 11 - Item de múltipla escolha de resposta múltipla . . . . . . . . . . . . . . 79

Figura 12 - Solução apresentada pelo aluno E2A18. . . . . . . . . . . . . . . . . 123

Figura 13 - Solução apresentada pelo aluno E1A11. . . . . . . . . . . . . . . . . . . 125

Figura 14 - Solução apresentada pelo aluno E1A15 . . . . . . . . . . . . . . . . . 127

Figura 15 - Solução apresentada pelo aluno E2A11. . . . . . . . . . . . . . . . 127

Figura 16 - Solução da questão proposta pelo aluno E1A12. . . . . . . . . . . . . . 128

Figura 17 - Visualização da solução da alternativa A . . . . . . . . . . . . . . . . . 136

Figura 18 - Visualização da solução da alternativa D . . . . . . . . . . . . . . . 136

Figura 19 - Solução apresentada pelo aluno E1A15 . . . . . . . . . . . . . . . . . 139

Figura 20 - Solução apresentada pelo aluno E2A10 . . . . . . . . . . . . . . . . . 147

Figura 21 - Solução apresentada pelo aluno E1A10 . . . . . . . . . . . . . . . . 153 



\section{Lista de tabelas}

Tabela 1 - Objetivo geral . . . . . . . . . . . . . . . . 26

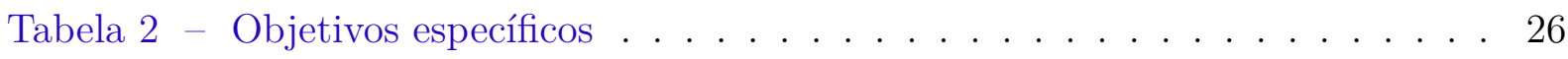

Tabela 3 - Distribuição dos itens da OBM (OBM, 2014a). . . . . . . . . . . 35

Tabela 4 - Inscrições na OBMEP na primeira e segunda fase e premiados por ano. 37

Tabela 5 - Classificação dos itens de acordo com o poder de discriminação na TCT (RABELO, 2013, p. 136), com adaptações. . . . . . . . . . . . . 63

Tabela 6 - Questionamentos de verificação de itens (RABELO, 2013, p. 217) . . . 81

Tabela 7 - Taxonomia de Borasi para os Usos de Erros . . . . . . . . . . . . . . 99

Tabela 8 - Análise de escore bruto dos candidatos . . . . . . . . . . . . . . . 114

Tabela 9 - Análise Geral da Prova da OBMEP-2014 a partir da TCT na amostra 114

Tabela 10 - Distribuição dos itens em relação ao parâmetro dificuldade, segundo a TCT. . . . . . . . . . . . . . . . . . . . . 115

Tabela 11 - Distribuição dos itens em relação a discriminação, pela TCT. . . . . . 115

Tabela 12 - Coeficientes bisseriais das alternativas de cada item. . . . . . . . . . 116

Tabela 13 - Porcentagem de marcação nas alternativas de cada item . . . . . . . . 116

Tabela 14 - Erro diante à construção de conhecimento em uma situação didática de Matemática, segundo Bodin (1997) _ . . . . . . . . . . . . 164

Tabela 15 - Erros de acordo com um modelo embasado nos mecanismos do processamento de informação, segundo Radatz (1979) . . . . . . . . . . . 165

Tabela 16 - As causas dos erros, segundo Casey (CLEMENTS, 1980 apud CURY,

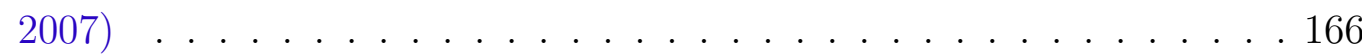





\section{Sumário}

Introdução $\ldots \ldots \ldots \ldots \ldots \ldots \ldots \ldots \ldots \ldots \ldots$

I FUNDAMENTAÇÃO TEÓRICA

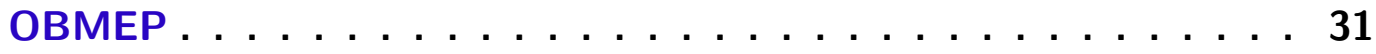

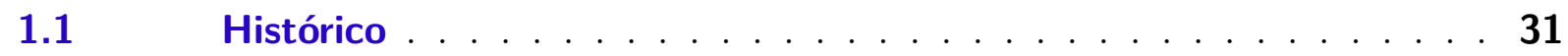

1.2 Olimpíada Internacional de Matemática . . . . . . . . . . . . 32

1.3 Olimpíada Brasileira de Matemática . . . . . . . . . . . . . . . 34

1.4 Olimpíada Brasileira de Matemática das Escola Públicas . . . . . . 36

1.5 Contribuições da OBMEP . . . . . . . . . . . . . 40

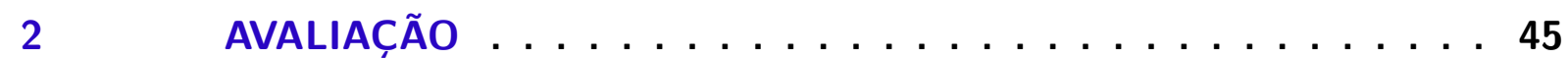

2.1 Avaliação a Serviço da Aprendizagem Matemática . . . . . . . . 45

2.2 Rompendo os Conceitos Avaliativos . . . . . . . . . . . . 46

$2.3 \quad$ Avaliação e Educação Matemática . . . . . . . . . . . . 51

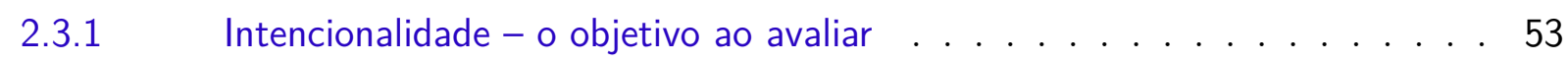

2.3.2 O conteúdo - o objeto de avaliação . . . . . . . . . . . . . 53

2.3.3 Forma - os procedimentos/instrumentos de avaliação . . . . . . . . . . 54

$2.4 \quad$ Um Instrumento para a Aprendizagem . . . . . . . . . . 55

3 INSTRUMENTO AVALIATIVO E A PSICOMETRIA . . . . . . 59

$3.1 \quad$ Teoria de $\operatorname{Resposta~ao~Item~\ldots ~.~.~.~.~.~.~.~.~.~.~.~.~.~} 59$

3.2 Teoria Clássica dos Testes . . . . . . . . . . . . . 60

$3.3 \quad$ Análise Gráfica dos Itens . . . . . . . . . . . . . . . . 64

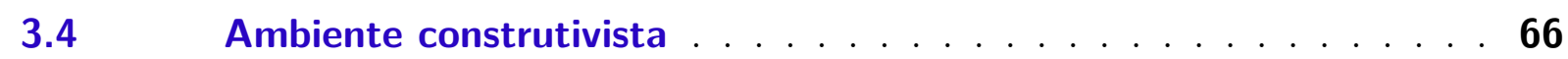

4 ENGENHARIA DE ITENS $\ldots \ldots \ldots \ldots \ldots$

$4.1 \quad$ Conceitos básicos de elaboração de itens . . . . . . . . . 69

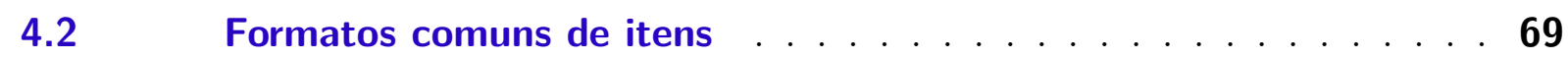

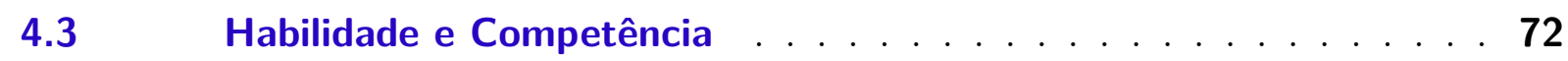

$4.4 \quad$ Estrutura básica de um item de múltipla escolha $\ldots \ldots \ldots 73$

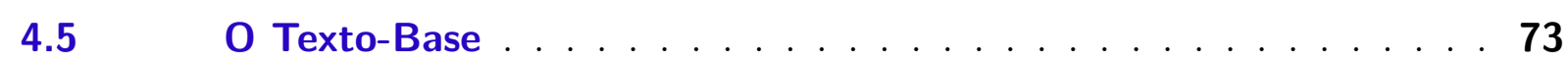

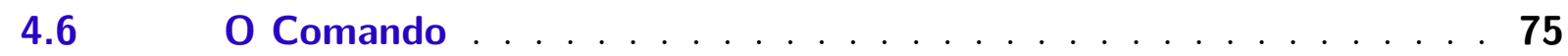

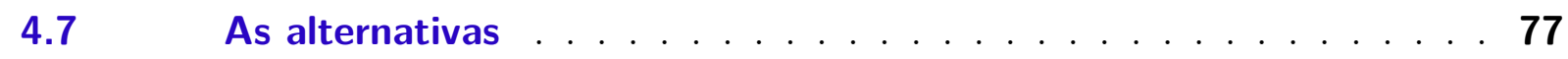

4.8 O Correto Uso da Língua Portuguesa na Avaliação para a Aprendizagem ..................... 78 


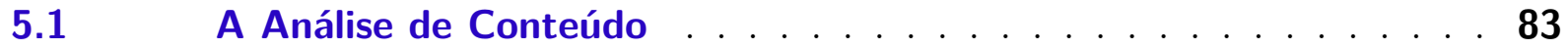

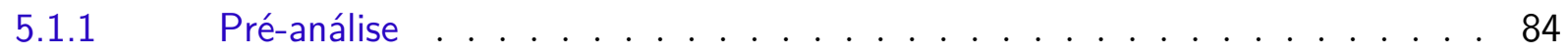

$5.1 .2 \quad$ A Exploração do Material . . . . . . . . . . . . . . . . . . . . . 84

5.1.3 Tratamento dos Resultados Obtidos e Interpretação . . . . . . . . . . . . . 85

5.1.3.1 Categorização . . . . . . . . . . . . . . . . . . 85

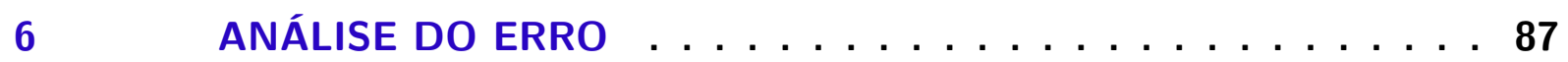

6.1 Errar: Uma Ação para a Aprendizagem Significativa . . . . . . 87

6.2 Erro: Bases Históricas . . . . . . . . . . . . . . . . . 90

$6.3 \quad$ O Erro e o Ambiente Construtivista . . . . . . . . . . . 92

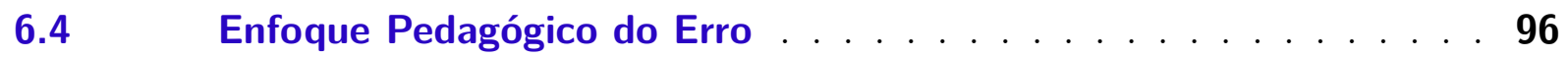

$6.5 \quad$ Erro e a Avaliação de Larga Escala . . . . . . . . . . . . . 100

II $\quad$ ANÁLISE E DISCUSSÃO 103

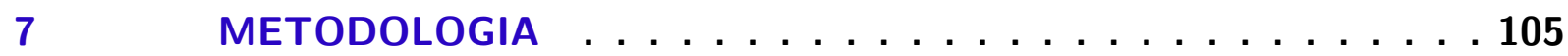

7.1 Coleta de dados - estudo quantitativo . . . . . . . . . 105

7.2 Coleta de dados - estudo qualitativo $\ldots \ldots \ldots 107$

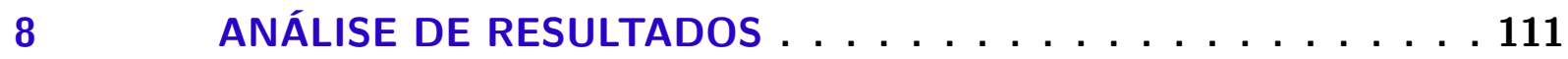

$8.1 \quad$ Análise Geral do Instrumento . . . . . . . . . . . . . . 111

8.2 Análise Geral da OBMEP-2014, nível 2, primeira fase . . . . . . 111

8.2 .1 Matriz de Referência . . . . . . . . . . . . . . . . . 111

8.2.2 Análise global dos itens . . . . . . . . . . . . . . . . . . 112

8.2 .3 As alternativas . . . . . . . . . . . . . . . . . . . 112

8.2.4 Análise quantitativa - TCT . . . . . . . . . . . . . . . . . 113

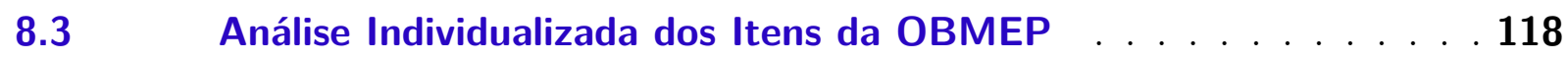

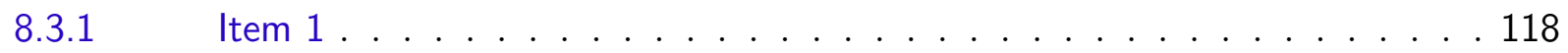

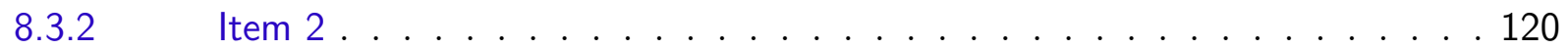

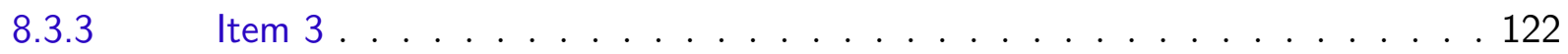

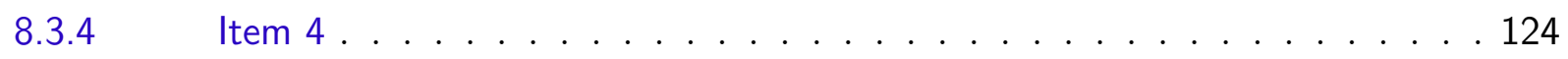

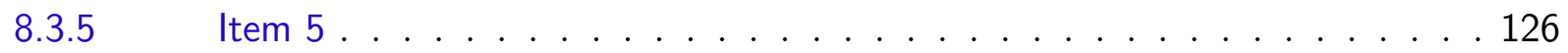

$8.3 .6 \quad$ Item $6 \ldots \ldots \ldots \ldots$

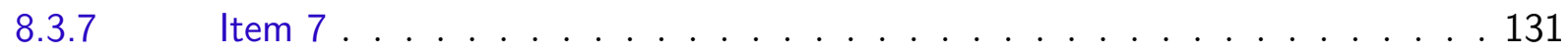

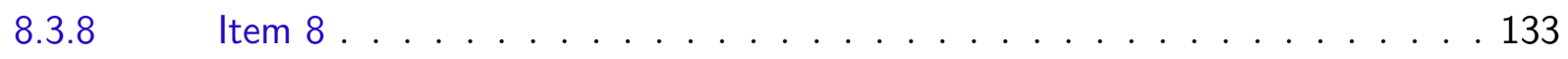

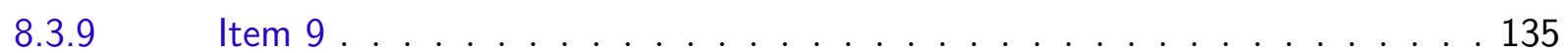

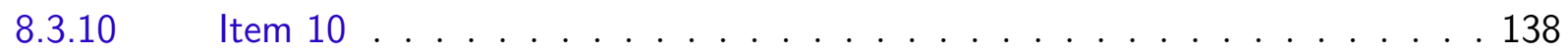

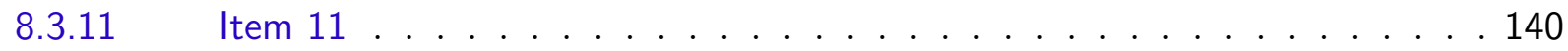

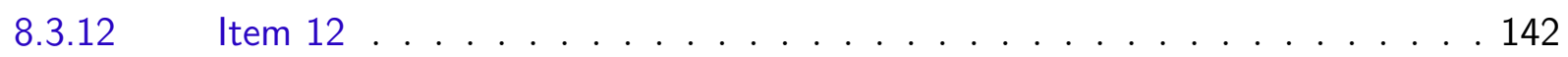


8.3.13 Item $13 \ldots \ldots \ldots \ldots \ldots \ldots$

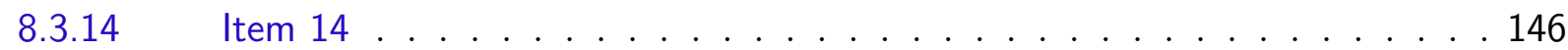

$8.3 .15 \quad$ Item $15 \ldots \ldots \ldots \ldots \ldots$

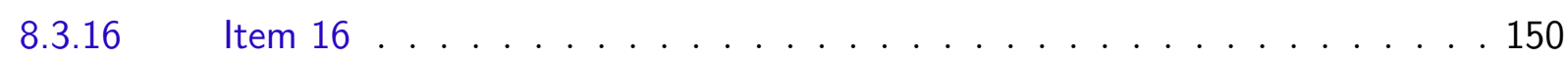

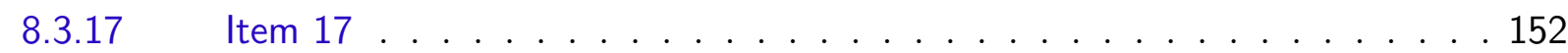

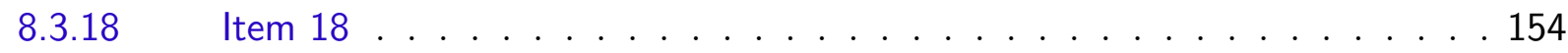

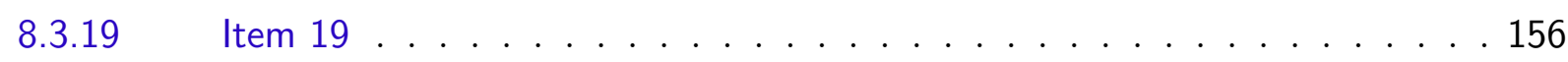

$8.3 .20 \quad$ Item $20 \ldots \ldots \ldots \ldots$

Considerações Finais . . . . . . . . . . . . . . . . . . . . . 161

Referências . . . . . . . . . . . . . . . 169

$\begin{array}{ll}\text { APÊNDICES } & 173\end{array}$

APÊNDICE A - TERMO DE CONSENTIMENTO . . . . . . . 175

APÊNDICE B - REQUERIMENTO CEBRASPE . . . . . . . . . . 177

APÊNDICE C - ATIVIDADE EXTRA . . . . . . . . . 179

APÊNDICE D - QUESTIONÁRIO DE ENTREVISTA . . . . . . . . 183

ANEXOS

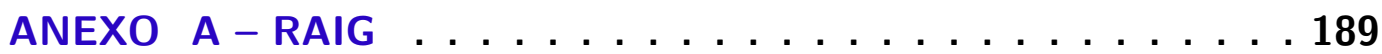

ANEXO B - PROVA OBMEP $2014 \ldots \ldots \ldots$

ANEXO C - SOLUÇÃO DA PROVA DA OBMEP $2014 \ldots 199$

ANEXO D - RESPOSTAS AO QUESTIONÁRIO (APÊNDICE D) . 207

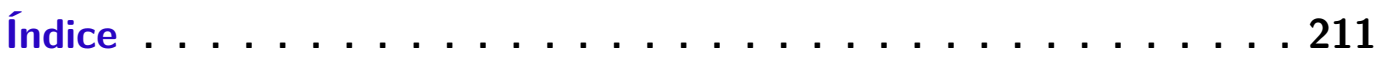





\section{Introdução}

Sabemos que pensar matematicamente exige, desde cedo, um esforço de abstração e formalização que demanda, por sua vez, desvincular o pensamento de propósitos e intenções imediatas. Ensinar Matemática é fazer ao aluno um convite à abstração ${ }^{1}$. Esse convite, no entanto, parece que só pode ser aceito ou compreendido se o professor adotar uma metodologia que possibilite mediações progressivas entre os significados matemáticos e aqueles que o aluno domina.

Em uma pedagogia centrada na figura do professor, cabe ao docente a tarefa de ensinar ou orquestrar em uma sala de aula todos os elementos envolvidos na aprendizagem. Um dos elementos que envolve enorme discussão é a verificação da aprendizagem por meio de um instrumento que revele, com maior fidedignidade possível, o que o aluno realmente aprendeu, ou seja, uma avaliação que carrega em si um retrato do quadro de aprendizagem que demonstre os conceitos aprendidos ou não.

É nesse sentido que a avaliação da aprendizagem escolar está sendo entendida, como processo, como prática que busca respostas sobre como se dão os processos com ela envolvidos. Nesta perspectiva, o que se busca com a avaliação da aprendizagem escolar é interrogar o que é diretamente observável, percorrer caminhos, compreender processos, seguir vestígios e, com isso, inferir sobre o que não é diretamente observável, ou seja - investigar. Por este motivo, adota-se a perspectiva de avaliação da aprendizagem escolar como prática de investigação (BURIASCO; FERREIRA; CIANI, 2009, pg. 73).

E, mais ainda, como esse instrumento pode ser utilizado como propósito de ressignificar a aprendizagem tanto para o professor quanto para o aluno? Se tomarmos numa visão macro, como os instrumentos estão sendo utilizados pelos os órgãos governamentais de forma a revelar a atual situação da aprendizagem em Matemática?

Esses questionamentos instigam a investigação tanto das avaliações em larga escala quanto da avaliação em sala de aula, para entender como elas podem revelar e construir para o aluno um significado para as atividades que ele realiza. Que no caso deste estudo visa a construção de instrumento na esfera macro de ensino que pode ser aplicada de forma a contribuir para um ambiente construtivista de aprendizagem de Matemática na sala de aula, de forma que o professor seja agente de significação do instrumento como um todo para o educando.

A avaliação da qualidade do trabalho ou do desempenho do aluno requer que o professor possua concepção de qualidade apropriada à tarefa e

1 Abstração, para Piaget, é a internalização da ação. O conceito de abstração é amplo e tem diversas interpretações dadas por outros autores. 
seja capaz de julgar de acordo com essa concepção. O aluno, por sua vez, precisa ter concepção de qualidade similar à do professor, ser capaz de monitorar continuamente a qualidade do que está sendo produzido durante o próprio ato de produção e ter repertório de encaminhamentos ou estratégias aos quais possa recorrer. Isso significa que ele tem de ser capaz de julgar a qualidade da sua produção e de regular o que está fazendo enquanto o faz (VILLAS-BOAS, 2006, p. 81).

Assim, com um instrumento bem elaborado pelo Estado aplicado ao estudante e com relatórios de desempenho bem redigidos, na linguagem em que os docentes compreendem, o professor torna-se uma investigador dos resultados apresentados e pode tomar posturas que reordene sua prática pedagógica. Para reorientar sua prática, sugere-se a análise dos erros cometidos pelos estudantes como forma de investigação dos problemas relacionados ao ensino e aprendizagem escolar de Matemática.

Os erros produzidos no processo de aprendizagem de Matemática devem ser encarados como indicadores da atuação dos processos subjacentes à construção de um conceito e das variáveis que influenciam externamente esses processos, sobretudo aquelas ligadas ao processo de ensino e aprendizagem.

Para entender os erros mais frequentes é necessário investigar a natureza e a produção de conceitos de um dado campo de investigação, no caso a Matemática, explicitando as principais dificuldades associadas à construção dos mesmos.

O erro auxilia na aquisição consciente e elaborada de uma conduta ou de uma habilidade, bem como contribui para avançar um passo à frente na aprendizagem e no desenvolvimento. Assim, ele serve como ponto de partida para novas investigações que levarão o indivíduo a buscar soluções que satisfarão não apenas a situação proposta, mas também como resposta a outras proposições. Desse modo, o erro se constitui importante instrumento de intervenção didática, pois, a partir dele, o docente tem a possibilidade de observar e valorizar a diversidade na sala de aula e, consequentemente, escolher a conduta a ser utilizada no ensino de determinado conteúdo.

Como se espera analisar o erro, por quê não prevê-los com antecedência antes da aplicação de um teste escrito? E, assim, ao se construir o instrumento, de larga escala ou de sala de aula, o elaborador se coloca em sintonia com a prática de aprendizagem do estudante. Desse modo, pode-se aplicar na construção dos itens que comporão a prova escrita conceitos que justifiquem a aplicação do próprio instrumento, de forma a se ter uma avaliação formativa. Cabe resgatar o que Villas Boas nos diz sobre a avaliação como prática de investigação:

Assim, do levantamento dos verbetes acima apresentados e brevemente discutidos, constituímos o que aqui entenderemos por "avaliação como prática de investigação": um processo de buscar conhecer ou, pelo menos, obter esclarecimentos, informes sobre o desconhecido por meio de um conjunto de ações previamente projetadas e/ou planejadas, processo no 
qual se procura seguir rastros, vestígios, esquadrinhar, ir à pista do que é observável, conhecido (VILLAS-BOAS, 2006, p. 82).

Assim, um estudo que perpassa um instrumento de larga escala e seu significado para o estudante, merece relevância na perspectiva de todos os agentes que estão presentes no processo. Desde os idealizadores, os elaboradores e professores até o principal ator, o aluno. O aluno que pode ressignificar os conceitos aprendidos, superar obstáculos na aprendizagem, destacar-se no meio acadêmico e/ou, até mesmo, romper paradigmas sociais.

\begin{abstract}
Acredita-se que uma prova escrita, na perspectiva da avaliação como prática de investigação, deve conter questões que possibilitem ao estudante trabalhar do seu próprio "jeito" com as informações do enunciado na busca não somente de resolver a questão, mas também de produzir conhecimento matemático a partir dela, de proporcionar resoluções a partir das quais o professor possa investigar as maneiras pelas quais os sujeitos interpretam o enunciado, elaboram estratégias e utilizam procedimentos para resolver uma questão, que, em muitos casos, são resultantes de processos sistemáticos, tanto sintáticos como semânticos, os quais eles próprios constroem (SANTOS, 2007 apud BURIASCO; FERREIRA; CIANI, 2009, pg. 80).
\end{abstract}

Após estudos realizados na disciplina Avaliação Educacional do Mestrado Profissional em Matemática, na qual, a partir de análises de avaliações de larga escala e da "engenharia de construção itens" (RABELO, 2013, p. 177), constatou-se a importância de se praticar uma metodologia de avaliação em Matemática diferente da que tradicionalmente encontramos nas escolas e que seja mobilizadora do desenvolvimento de habilidades e competências dos estudantes.

Com isso, surgiu a intenção de levar aos docentes de Matemática um pouco dessa formação, que pode contribuir para a discussão sobre a intencionalidade de se avaliar para a aprendizagem dos estudantes, em contraponto à tradicional avaliação das aprendizagens. Estes novos paradigmas levaram a uma reformulação da minha própria prática docente, corroborada com a visão de Esteban, acerca da postura investigativa do professor face a avaliação da aprendizagem escolar.

\footnotetext{
Assumir a avaliação da aprendizagem escolar como prática de investigação implica colocar-se em uma postura de investigação, o que exige, por parte do professor, o reconhecimento da existência de uma multiplicidade de caminhos percorridos pelos estudantes, a admissão de que, tal como eles, está em constante processo de elaboração de conhecimento. Sob esta perspectiva, a avaliação é então realizada como uma prática que possibilita ao professor a busca de desvelar o processo de aprendizagem dos estudantes, bem como acompanhar e participar dele (ESTEBAN, 2003 apud BURIASCO; FERREIRA; CIANI, 2009, pg. 82).
}

Como ponto de partida, escolhi fazer uma análise da prova de primeira fase da Olimpíada Brasileira de Matemática das Escolas Públicas (OBMEP), bem como das res- 
postas que os alunos de oitavo e nono anos do ensino fundamental apresentaram durante a realização do exame. Será realizado um estudo de caso, que pode pontuar e contribuir para uma nova visão do professor e dos elaboradores a respeito da relevância que um instrumento, elaborado a partir de objetivos ligados ao alvo da aprendizagem - o aluno, pode ter na aprendizagem Matemática em todo o território nacional.

O objetivo é fazer uma análise de conteúdo dos itens da prova no que diz respeito às técnicas recomendadas pela metodologia de construção de itens e categorizar a natureza dos erros apresentados pelo grupo de estudantes pesquisado, conforme objetivo geral, objetivos específicos e procedimentos metodológicos utilizados para a coleta de dados da pesquisa, apresentados na Tabelas 1 e 2.

Tabela 1 - Objetivo geral

\section{Objetivo Geral}

Analisar os itens e as respostas dos estudantes do $8^{\circ}$ e $9^{\circ}$ ano do ensino fundamental às provas da OBMEP como meio para oferecer subsídios para a prática docente de professores de Matemática.

Tabela 2 - Objetivos específicos

\begin{tabular}{|c|c|}
\hline Objetivos Específicos & Procedimentos \\
\hline $\begin{array}{l}\text { Investigar em que medida os itens das provas da OB- } \\
\text { MEP, nível 2, aplicadas no ano } 2014 \text { respeitam as reco- } \\
\text { mendações da técnica denominada Engenharia de Cons- } \\
\text { trução de Itens para uma avaliação de larga escala. }\end{array}$ & $\begin{array}{l}\text { Análise detalhada de cada item e do instrumento como } \\
\text { um todo, a partir da matriz de referência e da proposta } \\
\text { de solução dos itens pela OBMEP à luz da Engenharia } \\
\text { de Construção de Itens. } \\
\text { Verificar a intencionalidade na elaboração dos distrato- } \\
\text { res na prova da primeira fase da OBMEP. }\end{array}$ \\
\hline $\begin{array}{l}\text { Determinar os índices a partir da TCT para análise dos } \\
\text { itens da OBMEP no grupo analisado. }\end{array}$ & $\begin{array}{l}\text { A partir das folhas de respostas dos alunos preenchidas } \\
\text { quando da aplicação da OBMEP nas escolas investiga- } \\
\text { das, determinar a dificuldade, o índice de discriminação } \\
\text { e a análise gráfica do item (AGI) da prova analisada, } \\
\text { além dos percentuais de marcação e dos coeficientes bis- } \\
\text { seriais por alternativa de cada item. }\end{array}$ \\
\hline $\begin{array}{l}\text { Categorizar os erros cometidos pelo grupo de alunos que } \\
\text { respondeu às provas da OBMEP nas escolas pesquisa- } \\
\text { das. }\end{array}$ & $\begin{array}{l}\text { Categorizar as inferências de erros, cometidos pelo } \\
\text { grupo pesquisado, a partir da análise dos distratores } \\
\text { de cada item da prova comparando-se com o referencial } \\
\text { teórico sobre análise do erro. }\end{array}$ \\
\hline $\begin{array}{l}\text { Evidenciar formas de tratamento de erro para os profes- } \\
\text { sores de Matemática a partir das análises das respostas } \\
\text { dos estudantes do grupo em estudo. }\end{array}$ & $\begin{array}{l}\text { Após a categorização dos erros inferidos a a partir das } \\
\text { alternativas apresentadas em cada item, reforçar as for- } \\
\text { mas de tratamento ao erro de acordo com o referencial } \\
\text { teórico sobre análise do erro. }\end{array}$ \\
\hline $\begin{array}{l}\text { Provocar um questionamento em relação a elaboração } \\
\text { de um instrumento de avaliação que contribua para uma } \\
\text { aprendizagem significativa. }\end{array}$ & $\begin{array}{l}\text { Apresentar o feedback dos resultados apresentados no } \\
\text { estudo às escolas pesquisadas. } \\
\text { Incentivar uma tomada de postura do docente frente a } \\
\text { investigação dos erros apresentados pelo estudante di- } \\
\text { ante de um instrumento avaliativo. }\end{array}$ \\
\hline
\end{tabular}

Para conseguir atingir os propósitos anteriormentes explicitados, dividiu-se este trabalho em duas partes. Na primeira, apresentam-se os referenciais teóricos que fundamentam esta investigação. São eles:

\section{Olimpíada Brasileira de Matemática das Escolas Públicas (OBMEP): apresen-}

ta-se um breve histórico sobre as olimpíadas da Matemática, desde as competições antigas até as olimpíadas modernas, comentando-se sobre as ideias de seus regulamentos e a relevância destes eventos para a produção cientifica e para a sociedade. 
Avaliação: revela o caráter formativo de avaliações e denota a importância do estudo de avaliações nos três níveis educacionais, concentrando-se numa perspectiva de investigação realizada pelo professor.

Instrumento Avaliativo e a Psicometria: apresenta-se a importância dos estudos psicométricos da avaliação com o apoio da TCT e da TRI.

Engenharia de Itens: estabelece critérios para a boa prática construção de itens em uma avaliação de larga escala a partir dos estudo de Rabelo.

Análise de conteúdo: apresentam-se conceitos de uma pesquisa embasada na análise de conteúdo como forma de investigação documental de forma a embasar este estudo.

Análise do Erro: uma ação para a aprendizagem significativa: estabelece como deve ser o tratamento dos erros para uma aprendizagem Matemática significativa, apresentando as concepções de tratamento de erros. E além disso, traz a categorização e o tratamento de erros por diversos autores.

Na segunda parte, intitulada "Análise e Discussão", são apresentados os capítulos que qualificam este estudo:

Metodologia: esclarecimento acerca das escolhas metodológicas e do caminho percorrido nessa investigação.

Análise de resultados: estudo do instrumento avaliativo da OBMEP agregado ao grupo de estudo. Esta análise foi divida em duas seções: a Análise Geral do Instrumento e a Análise Individualizada de Itens da OBMEP.

Considerações Finais: considerações sobre a investigação realizada. 



\section{Parte I}

Fundamentação Teórica 



\section{OBMEP}

\subsection{Histórico}

A Olimpíada Brasileira de Matemática das Escolas Públicas - OBMEP, além de uma olimpíada de conhecimentos em Matemática, é uma avaliação de larga escala e uma política pública, mundialmente reconhecida, segundo Maranhão. De acordo com a mesma autora, é considerada

uma das maiores iniciativas governamentais voltadas ao processo de ensino aprendizagem em Matemática, visando melhorar a motivação, o interesse e o desempenho dos alunos das escolas públicas brasileiras com cobertura em quase todo território nacional (MARANHãO, 2011, p. 13).

Em busca de características do projeto da OBMEP é necessário um breve histórico deste tipo de competições, de forma a entender o formato do projeto que hoje está em sua $11^{\mathrm{a}}$ edição.

A realização de Olimpíadas de Matemática no mundo datam do século XIX. No entanto, no século XVI, com características bem diferentes, já havia duelos matemáticos, que eram famosos desafios nos quais importantes matemáticos empenhavam sua reputação, dinheiro e, até mesmo, suas cátedras em universidades italianas. Nessa época, segundo Bellos (2011), grande parte dos matemáticos estavam empenhados em encontrar soluções para problemas que pudessem ser apresentadas nas futuras competições de habilidade Matemática. Um matemático, cujas habilidades permitissem que detivesse uma cátedra em uma universidade, tinha reconhecimento público e uma condição econômica privilegiada. Essa situação social despertava o interesse de outros matemáticos ainda sem prestígio, que desafiavam publicamente matemáticos respeitados e experientes. Nessas competições, em geral, um conjunto de trinta problemas era proposto por ambos, vencendo aquele que resolvesse o maior número de problemas propostos pelo oponente.

Exemplo histórico da ocorrência de tais duelos é a competição entre Niccoló Tartaglia e Antonio Fiore. Eles eram chamados de coisistas, e detinham a fama de resolver equações cúbicas. O concurso público, em questão, terminou com a vitória de Tartaglia, que resolveu todos os problemas propostos por seu adversário. Tal feito incitou Girolamo Cardano a investigar o método usado por Tartaglia. Após várias investidas de Cardano, Tartaglia revelou seu método mas com o compromisso de sigilo daquele (BELLOS, 2011, p. 216).

Mas Cardano contou o método ao seu secretário Ludovico Ferrari, que o aperfeiçoou, descobrindo assim, uma maneira de resolver as equações quárticas. Cardano, em 
um dilema moral do sigilo versus a publicação da descoberta por Ferrari, publicou o método de Tartaglia, onde este último seria apenas o coinventor do método de resolução de cúbicas (BELLOS, 2011, p. 218).

O evento, citado, demonstra que haviam competições Matemáticas, com formatos e intenções diversas aos modelos contemporâneos, mas que trouxeram benefícios conceituais à Matemática. A procura por matemáticos talentosos é um objetivo presente nas diversas competições.

Segundo Maciel (2009), com inspiração nos jogos olímpicos, os quais foram influenciados pelos festivais esportivos que os gregos realizavam na antiga Élida, realizou-se em 1894, na Hungria, a primeira Olimpíada de Matemática, em homenagem a Jósef Kürschák.

Estas competições matemáticas eram chamadas "Eotvos". Devido à maneira com que foram estruturadas, é possível afirmar que essas competições são as precursoras do que hoje conhecemos como "Olimpíadas de Matemática". Em 1934, foi organizada aquela que pode ser considerada como a primeira Olimpíada de Matemática "moderna" na cidade de Leningrado (URSS) . Assim, deu-se o primeiro passo para ser disseminada a elaboração de competições matemáticas pelo resto da Europa e para todo o mundo (MACIEL, 2009).

Essas competições têm por objetivo desenvolver nos jovens o gosto e o prazer de estudar Matemática - objetivo motivacional de aprendizagem -, e também, estimular o ensino e a aprendizagem da Matemática em todos os seus níveis - objetivo político educacional.

O programa de Olimpíadas de Matemática é reconhecido em todos os países do mundo desenvolvido como eficiente instrumento para atingir o objetivo motivacional. Aproveitando o natural gosto dos jovens pelas competições, as Olimpíadas de Matemática têm conseguido estimular alunos a estudar conteúdos além do currículo escolar e, também, por outro lado, aumentar e desenvolver a competência dos professores. Entre as Olimpíadas de Matemática hoje realizadas, destacam-se a Olimpíada Internacional de Matemática (International Mathematical Olympiad - IMO) e a Olimpíada Ibero-Americana de Matemática (OIAM).

\subsection{Olimpíada Internacional de Matemática}

De acordo com IMO (2014), a primeira edição da Olimpíada Internacional de Matemática (International Mathematical Olympiad - IMO) foi realizada em 1959, com a participação de alguns países como Bulgária, Hungria, Polônia e Romênia, além das, hoje extintas, Alemanha Oriental, Tchecoslováquia e União Soviética (URSS). Com o passar do tempo, o número de países foi aumentando consideravelmente, chegando aos 101 que participaram da competição em 2014 na Africa do Sul. Em 1979, a competição realizou- 
se em Londres, onde o Brasil teve a sua primeira participação, e, desde então, compete anualmente de forma ininterrupta. Além disso, o Brasil será sede da IMO em 2017.

Nas primeiras edições da IMO, cada país podia inscrever até oito alunos na competição. Em 1982, esse número foi reduzido para quatro, sendo aumentado para seis no ano seguinte, número que permanece até hoje. Os competidores devem ter menos de 21 anos de idade, com nível de escolaridade igual ou inferior ao Ensino Médio.

A IMO é uma competição individual, não havendo delegações nacionais. A premiação é composta de medalhas de ouro, prata e bronze, além de certificados de menção honrosa. A distribuição dos prêmios é realizada de tal forma que as medalhas sejam entregues à metade dos estudantes participantes. Os certificados de menção honrosa são entregues ao estudante que, não tendo recebido qualquer tipo de medalha, tenha resolvido corretamente algum dos seis problemas propostos na competição, incentivando os competidores a procurar desenvolver soluções completas às questões propostas.

Faltando aproximadamente quatro meses para o início da competição, cada país participante sugere até seis questões à Comissão Organizadora da IMO. As questões devem abordar assuntos tratados no Ensino Médio: Geometria, Teoria dos Números, Análise Combinatória e Álgebra. A partir dessas sugestões, é formada uma lista com trinta questões.

A escolha das questões que irão compor a prova é realizada por um júri formado pelos chefes das equipes de todos os países participantes, liderado por uma comissão de quatro juízes indicados pelo país sede do evento. Há o descarte de questões com nível de dificuldade muito fácil ou muito difícil, sem o uso de pré-teste, pelos juízes. Depois de um debate, as questões são escolhidas em uma votação por maioria simples e as provas são organizadas nos idiomas oficiais da IMO: alemão, francês, inglês e russo. Se necessário, os chefes das equipes são os responsáveis pela tradução das questões para outros idiomas.

As provas têm seis questões, cada uma valendo sete pontos, fazendo com que a nota máxima obtida por um candidato seja 42 pontos. As provas são realizadas em dois dias, cada um com três questões. Cada prova tem a duração de 4 h 30 min e, tradicionalmente, a primeira questão é a mais fácil e a última, a mais difícil.

O Brasil tem tido participação expressiva nas competições da IMO (IMO, 2014). Nos últimos anos, o Brasil tem figurado entre os 35 países de melhor rendimento, conquistando, nas edições de 2009 e 2012, medalhas de ouro, além de medalhas de pratas, bronze e menções honrosas nas edições dos últimos anos. 


\subsection{Olimpíada Brasileira de Matemática}

Segundo o sítio da $\mathrm{OBM}^{1}$, no cenário nacional, em 1977, a Academia Paulista de Ciências criou a Olimpíada Paulista de Matemática. A Olimpíada Brasileira de Matemática - OBM, organizada pela Sociedade Brasileira de Matemática (SBM) e que concluiu sua $36^{\mathrm{a}}$ edição em 2014, surgiu dois anos mais tarde.

A OBM é uma competição organizada pela SBM, com a colaboração do IMPA Instituto Nacional de Matemática Pura e Aplicada, que passou por diversas mudanças em seu formato, contemplando em seus trabalhos iniciais os seguintes objetivos:

1. descobrir jovens com talento matemático excepcional, e colocá-los em contato com matemáticos profissionais e instituições de pesquisa de alto nível, propiciando condições favoráveis para a formação e o desenvolvimento de uma carreira de pesquisa;

2. selecionar os estudantes que representarão o Brasil em competições internacionais de Matemática; e

3. organizar no Brasil as diversas competições internacionais de Matemática.

Esse projeto foi ampliado e a Olimpíada Brasileira de Matemática foi realizada a partir do ano de 1998 de forma bastante diferente da que vinha sendo praticada nos anos anteriores. Isso porque passou a atingir os alunos desde a 5a. série (sexto ano) do ensino fundamental. A partir deste marco, acrescentou-se o seguinte objetivo: "interferir decisivamente na melhoria do ensino de Matemática em nosso país, estimulando alunos e professores".

Para a preparação dos alunos e para o aperfeiçoamento dos professores, a OBM distribuiu revistas e cartazes às escolas, contendo material para estudo e pesquisa, dedicados a cada faixa de escolaridade e desenvolvimento dos alunos. A realização das provas é uma conclusão dessa atividade.

A OBM é realizada anualmente em quatro níveis, de acordo com a escolaridade do aluno:

Nível 1: para alunos matriculados no $6^{\circ}$ ou $7^{\circ}$ ano do ensino fundamental na ocasião da realização da primeira fase da OBM;

Nível 2: para alunos matriculados no $8^{\circ}$ ou $9^{\circ}$ ano do ensino fundamental na ocasião da realização da primeira fase da OBM ou que, tendo concluído o ensino fundamental menos de um ano antes, não tenham ingressado no ensino médio até a data da realização da primeira fase da OBM;

1 http://www.obm.org.br/ 
Nível 3: para alunos matriculados em qualquer série do ensino médio na ocasião da realização da primeira fase da OBM ou que, tendo concluído o ensino médio menos de um ano antes, não tenham ingressado em curso de nível superior até a data de realização da primeira fase da OBM; e

Nível universitário: para alunos que ainda não tenham concluído o curso superior (normalmente estudantes universitários em nível de graduação, podendo ser estudantes de qualquer curso e qualquer período).

Para cada um dos níveis, a OBM contempla fases de acordo com o nível. Na primeira, qualquer aluno interessado poderá participar. Para participar das outras, existirá um critério de promoção.

A prova da primeira fase é de múltipla escolha, contendo de 20 a 25 questões sobre conteúdo adequado a cada um dos níveis de escolaridade. Em todas as fases, serão apresentadas nas questões situações inovadoras, porém embasadas em conteúdos tradicionais das escolas, de acordo com a Tabela 3.

Tabela 3 - Distribuição dos itens da OBM (OBM, 2014a).

\begin{tabular}{ccl}
\hline Fase & Nível & Formato da Prova \\
\hline Primeira & Todos & Uma prova de múltipla escolha com 20 a 25 questões. \\
Segunda & Todos & Uma prova mista. \\
Terceira & 1 & Uma prova discursiva com 5 problemas. \\
& 2 e 3 & $\begin{array}{l}\text { Duas provas discursivas realizadas em dois dias conse- } \\
\text { cutivos, com } 3 \text { problemas em cada dia. }\end{array}$ \\
\hline & Universitário & Uma prova discursiva com 6 problemas. \\
\hline
\end{tabular}

As provas da primeira e segunda fases da OBM são realizadas nas escolas que se cadastraram. A correção das provas também é realizada nas escolas, com o envolvimento de seus professores, de acordo com critérios determinados pela organização. Os coordenadores devem oferecer locais alternativos aos alunos que desejarem participar da Olimpíada, caso o colégio onde realizam seus estudos não venha a se inscrever. A prova da terceira fase é realizada em um local central designado pelo coordenador local e a correção é feita pelo comitê organizador da OBM.

Alunos que ganharam medalha de ouro, prata ou bronze na OBM de determinado ano estão automaticamente classificados para todas as fases da OBM do ano subsequente, inclusive se houver mudança de nível.

A pontuação final dos alunos que participaram das três fases é feita pelas Bancas Examinadoras, organizadas pelas Coordenações Regionais, as quais atribuem um ponto a cada questão da Primeira Fase, sessenta pontos para cada problema da Segunda Fase e cinquenta pontos para cada problema da Terceira Fase. Além disso, na classificação final, 
são levados em conta os pontos acumulados nas duas fases anteriores. A partir dessa classificação, a OBM premia os alunos com medalhas de ouro, prata e bronze e certificados de menção honrosa. Entre os premiados são selecionados aqueles que formarão as equipes brasileiras na Olimpíada do Cone Sul (4 estudantes, com até 16 anos); na Olimpíada Internacional de Matemática (6 estudantes do ensino médio, com até 19 anos); na Olimpíada Ibero-Americana (4 estudantes, com até 18 anos) e na Competição Internacional de Matemática (universitários). Essas competições são realizadas anualmente, sempre em um país diferente.

A OBM sempre foi dedicada a encontrar jovens talentos para a Matemática ou para Ciências Exatas e, nesse aspecto, tem cumprido sua finalidade. Existem brilhantes matemáticos e cientistas de renome mundial que tiveram origem nas Olimpíadas de Matemática. A título de exemplo, cita-se o matemático Artur Avila Cordeiro de Melo, de 35 anos, que recebeu recentemente (2014) a Medalha Fields, o mais tradicional e prestigioso prêmio da Matemática internacional (OBM, 2014b).

Artur é o primeiro pesquisador latino-americano a receber a medalha. O prêmio é outorgado pela União Internacional de Matemáticos (IMU, da sigla em inglês) a cada quatro anos a pesquisadores com menos de 40 anos, cujos trabalhos sejam considerados fundamentais para o avanço da Matemática. O prêmio foi entregue durante a cerimônia de abertura do Congresso Internacional de Matemáticos, realizado na cidade de Seul, Coreia do Sul.

A Medalha Fields foi concedida pela primeira vez em 1936. Contornando a medalha está a inscrição (em latim) "TRANSIRE SUUM PECTUS MUNDOQUE POTIRI", que significa "Superar os limites da inteligência e conquistar o universo".

Artur Avila coleciona medalhas desde 1992, quando conquistou uma medalha de bronze na OBM. Nos anos que seguiram obteve medalhas de ouro na competição nacional e uma medalha de ouro na Olimpíada Internacional de Matemática (IMO), em 1995.

\subsection{Olimpíada Brasileira de Matemática das Escola Públicas}

A primeira edição da Olimpíada de Matemática das Escolas Públicas (OBMEP) foi realizada em 2005. O Brasil foi surpreendido por uma proposta de inscrição em uma Olimpíada de Matemática que contemplava somente as escolas públicas de Educação Básica. Este foi o ponto de partida para a criação da OBMEP, cujo lema era "Somando Novos Talentos".

Assim, a principal razão para a existência da OBMEP são os alunos das escolas públicas, seus desempenhos, interesse e motivação pela Matemática. Este grupo de atores individuais é o foco principal dessa política porque está no cerne de problemas existentes e inter-relacionados: 
o baixo desempenho dos alunos em Matemática, a importância da Matemática para o desenvolvimento tecnológico do país, a baixa adesão dos profissionais a esta carreira, a necessidade de profissionais para a formação de novos alunos (BARBOSA, 2014, p. 37).

Com uma estratégia de divulgação do evento bastante eficiente, os organizadores conseguiram a participação de 10.520.831 inscritos, 30.031 escolas, contemplando 93,5\% dos municípios brasileiros. Essa adesão colocou o Brasil como recordista mundial em número de participantes em competições de Matemática, "superando o último Concours Kangourou, realizado na França, que contou com a participação de quatro milhões de competidores oriundos de vários países do mundo" (MACIEL, 2009).

A Tabela 4 lista o número de participantes e premiados nos últimos 10 anos.

Tabela 4 - Inscrições na OBMEP na primeira e segunda fase e premiados por ano.

\begin{tabular}{cccc}
\hline Ano & Primeira Fase & Segunda Fase & Premiados \\
\hline 2005 & 10.520 .831 & 457.725 & 31.109 \\
2006 & 14.181 .705 & 630.864 & 34.743 \\
2007 & 17.341 .732 & 780.333 & 33.003 \\
2008 & 18.326 .029 & 789.998 & 33.017 \\
2009 & 19.198 .710 & 841.139 & 33.011 \\
2010 & 19.665 .928 & 863.000 & 33.256 \\
2011 & 18.720 .068 & 818.566 & 33.202 \\
2012 & 19.166 .371 & 823.871 & 45.434 \\
2013 & 18.762 .859 & 954.926 & 44.835 \\
2014 & 18.192 .526 & 907.446 & 45.664 \\
\hline
\end{tabular}

Segundo Schirlo e Meza (2013), o formato da OBMEP foi construído com base em um projeto que inclui como objetivo o desenvolvimento de estratégias que possibilitem melhorar a qualidade do Ensino de Matemática na Educação Básica. Trata-se do Projeto NUMERATIZAR: "Descobrir, divulgar e aprimorar os talentos de nossa juventude é a forma mais efetiva e rápida de inclusão social".

Esse projeto, desenvolvido no estado do Ceará a partir de 2003, sob a supervisão da Universidade Federal do Ceará (UFC), foi motivado pelos resultados obtidos pela utilização da estratégia das Olimpíadas de Matemática nas escolas privadas de Fortaleza$\mathrm{CE}$, cujos alunos se destacaram em Olimpíadas de Matemática e nos principais concursos vestibulares do país (BELLOS, 2007).

Em sua primeira edição, o NUMERATIZAR organizou uma Olimpíada de Matemática na qual participaram cerca de 110.000 alunos do $6^{\circ}$ ao $8^{\circ}$ ano do Ensino Fundamental e da $1^{\mathrm{a}}$ série do Ensino Médio de escolas públicas do Ceará. Seus idealizadores o conceberam como um projeto matemático de inclusão social, caracterizado por um conjunto de atividades que tinham como objetivo validar a hipótese de que é possível 
encontrar grande número de jovens talentos em Matemática em todas as classes sociais. Segundo um dos objetivos do projeto, após identificá-los ( $1^{\text {a }}$ Fase do Projeto), era necessário motivá-los a avançar nos estudos em Matemática (2 $2^{\mathrm{a}}$ Fase do Projeto) (SCHIRLO; MEZA, 2013, p. 5).

Com amplitude maior, a Olimpíada Brasileira de Matemática das Escolas Públicas é uma realização do IMPA, com apoio da SBM, e promoção do Ministério da Ciência e Tecnologia e Inovação (MCTI) e do Ministério da Educação (MEC). Esta competição é dirigida aos alunos do $6^{\circ}$ ao $9^{\circ}$ ano do Ensino Fundamental e aos alunos do Ensino Médio das escolas públicas municipais, estaduais e federais, que concorrem a prêmios de acordo com a sua classificação nas provas. Professores, escolas e secretarias municipais de educação também concorrem a prêmios. Segundo seu regulamento, os objetivos desta competição são (IMPA; SBM, 2014a):

(a) estimular e promover o estudo da Matemática entre alunos das escolas públicas;

(b) contribuir para a melhoria da qualidade da Educação Básica;

(c) identificar jovens talentos e incentivar seu ingresso nas áreas científicas e tecnológicas;

(d) incentivar o aperfeiçoamento dos professores das escolas públicas, contribuindo para a sua valorização profissional;

(e) contribuir para a integração das escolas públicas com as universidades públicas, os institutos de pesquisa e as sociedades científicas;

(f) promover a inclusão social por meio da difusão do conhecimento.

Os alunos participantes são divididos em 3 (três) níveis, de acordo com o seu grau de escolaridade:

Nível 1: alunos matriculados no $6^{\circ}$ ou $7^{\circ}$ ano do Ensino Fundamental.

Nível 2: alunos matriculados no $8^{\circ}$ ou $9^{\circ}$ ano do Ensino Fundamental.

Nível 3: alunos matriculados em qualquer ano do Ensino Médio.

Participam das provas somente os alunos que, na data da realização das provas, estiverem regularmente matriculados nas escolas inscritas. A OBMEP realiza-se em 2 (duas) etapas:

Primeira Fase: aplicação de prova objetiva (múltipla escolha) a todos os alunos inscritos pelas escolas; 
Segunda Fase: aplicação de prova discursiva aos alunos selecionados pelas escolas, $5 \%$ (cinco por cento) dos alunos que realizaram a primeira fase e obtiveram os melhores resultados. Havendo empate, as escolas devem divulgar previamente os critérios de desempate a serem aplicados.

A Primeira Fase caracteriza-se pela aplicação de prova com questões de múltipla escolha pelos professores das escolas inscritas na OBMEP, seguindo instruções e gabaritos elaborados pela Coordenação Geral da OBMEP. As notas da Primeira Fase não são consideradas para classificação final.

A Segunda Fase da OBMEP caracteriza-se pela aplicação de prova discursiva por fiscais selecionados pela Coordenação Geral para esse fim.

A OBMEP premia alunos, professores, escolas e secretarias municipais de educação, ao alunos da seguinte forma:

i. 500 (quinhentas) medalhas de ouro;

ii. 1.500 (mil e quinhentas) medalhas de prata;

iii. 4.500 (quatro mil e quinhentas) medalhas de bronze;

iv. Até 46.200 (quarenta e seis mil e duzentos) certificados de Menção Honrosa;

v. Programa de Iniciação Científica Jr. (PIC): bolsas de Iniciação Científica Jr do CNPq concedidas aos 6.500 alunos medalhistas matriculados em escolas públicas no ano seguinte à aplicação das avaliações. Em caso de vacância de bolsas, um medalhista poderá ser substituído por um aluno que tenha recebido uma Menção Honrosa e esteja matriculado no ensino público, a critério da coordenação do PIC; $\mathrm{e}$

vi. Programa de Iniciação Científica e de Mestrado (PICME): bolsas concedidas aos medalhistas de ouro, prata ou bronze de qualquer edição da OBMEP, regularmente matriculados no ensino superior, concedidas por diversas Instituições de Ensino Superior.

Aos professores, até o limite de 1.029 (mil e vinte e nove), e às Escolas, até 495 (quatrocentos e noventa e cinco), as premiação estarão vinculadas à pontuação de seus alunos, segundo os seguintes critérios:

i. 10 (dez) pontos para cada aluno premiado com medalha de ouro;

ii. 8 (oito) pontos para cada aluno premiado com medalha de prata;

iii. 6 (seis) pontos para cada aluno premiado com medalha de bronze; 
iv. 3 (três) pontos para cada aluno premiado com menção honrosa;

v. 1 (um) ponto para cada aluno que compareceu à Segunda Fase e não obteve premiação.

A premiação dos docentes será de aparelhos eletrônicos e assinaturas de revistas do professor. E serão distribuídos desde kits esportivos até material didático à escola.

Como visto, as escolas são responsáveis pela participação de seus alunos, não havendo limite para o número de inscritos e todos devem ser estimulados a participar. As escolas são responsáveis pela organização e pela infraestrutura da aplicação das provas da Primeira Fase e também pela sua correção, de acordo com o calendário determinado pela OBMEP. As escolas são também responsáveis pela guarda do material de provas e pela manutenção do sigilo do mesmo, desde o recebimento até a correção e envio da lista de classificados, cabendo até desclassificação em caso de quebra de sigilo.

A Coordenação Geral da OBMEP, designada pela Diretoria do IMPA, tem as seguintes responsabilidades:

(a) planejamento e organização do projeto;

(b) elaboração de material didático das provas e dos gabaritos;

(c) envio dos gabaritos das provas da Primeira Fase e de material didático às escolas;

(d) processamento das informações enviadas pelas escolas com os resultados da Primeira Fase;

(e) aplicação das provas da Segunda Fase;

(f) correção das provas da Segunda Fase e indicação de todas as premiações;

(g) conservação das provas da Segunda Fase por um período de 4 (quatro) meses a contar da data da divulgação dos resultados;

(h) manutenção da página do evento na internet atualizada com informações sobre a Olimpíada;

(i) elaboração do Relatório Final dos resultados.

\subsection{Contribuições da OBMEP}

A OBMEP é uma ação política pública que nasce em um momento de grandes transformações educacionais, principalmente no que se refere à avaliação em larga escala 
e à criação do Índice de Desenvolvimento da Educação Básica (IDEB). As ações motivadas pela Olimpíada podem ser confrontadas com os resultados de avaliações educacionais.

Entre as realizações da OBMEP desde sua criação até 2014, em sua décima edição, destacam-se, segundo IMPA e SBM (2014b):

- o atendimento pelo PIC de 36 mil e 500 alunos, uma oportunidade de estudar Matemática por 1 ano, com bolsa do CNPq;

- a distribuição para as escolas de material didático de qualidade, como apostilas do PIC e Banco de Questões, também disponível em sítio específico;

- o atendimento pelo PICME de cerca de 1.321 alunos;

- a preparação de medalhistas de ouro, selecionados para participar de competições internacionais, pelo PECI - Preparação Especial para Competições Internacionais;

- a preparação de competidores, em 2012, foi criado o POTI - Polos Olímpicos de Treinamento Intensivo - em parceria com a OBM, com o objetivo ampliar o acesso dos alunos brasileiros a treinamento para competições matemáticas;

- a preparação de docentes, em 2012, foi criado o PROF, programa destinado ao aperfeiçoamento dos professores de Matemática. Este programa está em seu terceiro ano no Estado de São Paulo, em parceria com a SEED;

- a preparação de estudantes, em 2013, a OBMEP lançou o programa Clubes de Matemática, que já conta com a adesão de cerca de 3000 alunos em 389 clubes em todo o Brasil;

- o lançamento do Portal da Matemática, com aplicativos e videoaulas que cobrem todo o currículo da Matemática, do sexto ano do Ensino Fundamental ao terceiro ano do Ensino Médio; e

- a mobilização dos Coordenadores Regionais da OBMEP para a realização de atividades, como seminários com professores e cerimônias de premiação.

Em 2015, com o apoio da CAPES, foi criado o programa OBMEP nas Escolas, voltado para o professor de Matemática das escolas públicas. O programa quer estimular atividades extraclasse com o uso dos materiais da OBMEP, tais como provas e Bancos de Questões. Professores de todo o país são habilitados e preparados para desenvolver essa atividade em sua escola ou em escolas vizinhas (OBMEP, 2015).

Ressalta-se que a contribuição da OBMEP vai além de criação, ampliação e manutenção de projetos a ela vinculados. Uma contribuição que propostas dessa natureza podem agregar à qualificação do Ensino de Matemática no país é a possibilidade de oferecer 
uma formação na qual o aluno, ao concluir sua escolarização básica, esteja "alfabetizado quantitativamente".

Cidadãos quantitativamente alfabetizados precisam conhecer mais que fórmulas e equações. Eles precisam de uma predisposição de olhar o mundo através de olhos matemáticos, para ver os benefícios (e os riscos) de pensar quantitativamente acerca de assuntos habituais e para abordar problemas complexos com confiança no valor do raciocínio cuidadoso. Alfabetização quantitativa dá poder às pessoas ao oferecer-lhes ferramentas para que pensem por si próprias, para fazer perguntas inteligentes aos especialistas e para confrontar a autoridade com confiança. Estas são habilidades requeridas para prosperar no mundo moderno (OCED, 2014, p. 5).

Essas habilidades vão ao encontro dos fundamentos filosóficos da Educação Matemática Crítica, de Ole Skovsmose, que defende a necessidade do entendimento do papel da Educação Matemática em uma sociedade democrática: “(...) a alfabetização Matemática, como construto radical, tem de estar enraizada em um espírito de crítica e em um projeto de possibilidades que habilite pessoas a participarem no entendimento e na transformação da sociedade" (SKOVSMOSE, 2004, p. 95).

Esse caráter inclusivo associado à OBMEP fica explícito na análise de sua estrutura de funcionamento, com suas Coordenações Regionais preocupadas em viabilizar a participação de alunos das mais diferentes regiões do país. Além disso, a sistemática de premiação segue o que tradicionalmente é utilizado nas competições olímpicas, mas proporcionou um avanço considerável na condução das atividades.

\begin{abstract}
Além disso, é necessário ressaltar que houve movimento considerável dentro de muitas escolas no sentido de divulgar e, até mesmo, preparar seus alunos para a OBMEP. Esse movimento levou professores a procurarem oportunidades de aprofundar e qualificar seu trabalho. Nesse sentido, a discussão sobre os resultados obtidos pelos alunos nas Olimpíadas pode oferecer subsídios à reflexão sobre a qualificação do Ensino de Matemática no país (MACIEL, 2009, p. 7).
\end{abstract}

O desempenho do Brasil nas avaliações do PISA - Programa Internacional de Avaliação de Estudantes, os relatórios das secretarias de educação e os relatórios de programas de capacitação de professores indicam que há no país uma deficiência séria na qualidade do ensino de Português e Matemática, disciplinas fundamentais na formação profissional e no exercício da cidadania. Em 2012, o resultado do PISA (OCED, 2014), apresenta uma ligeira melhora em Matemática: o Brasil saiu de 386 pontos, em 2009, e foi a 391 pontos. Mesmo assim não atingiu a média desejada que é de 494 pontos, ocupando a $58^{\text {a }}$ posição mundial. E quanto ao aprendizado, na escala de 6 níveis, a maior parte dos alunos situa-se nos primeiros níveis.

Em contrapartida, em 2012, foram distribuídas 4.500 medalhas aos alunos com melhor desempenho entre 19 milhões de alunos de mais de 99\% dos municípios brasilei- 
ros. Cocal dos Alves (PI) é exemplo entre as cidades com cerca de 12 mil habitantes que receberam número expressivo de medalhas. A partir do envolvimento dos alunos premiados em atividades de estudos em grupo ou monitorias acompanhadas por professores, elevou-se o nível de aprendizagem dos alunos. Em 2011, 89\% deles sabiam o esperado em Matemática nas séries finais do ensino fundamental (QEDU, 2014). Estes dados sugerem um impacto positivo da Olimpíada contribuiu no aprendizado dos estudantes de Cocal dos Alves, embora seja necessário um estudo mais aprofundado para mensurar este possível impacto.

No que diz respeito ao contato entre o aluno premiado e o meio universitário, na OBMEP, este é promovido a partir do PIC, pois seus responsáveis são professores universitários e o Programa se desenvolve sobretudo em salas universitárias, o que traz uma convivência natural do aluno da escola pública com a universidade. Enquetes realizadas entre os medalhistas da OBMEP mostram que a vontade geral dos alunos é a de prosseguir nos estudos universitários.

Observa-se ainda que uma parcela significativa não chega à universidade por causa de suas limitações econômicas, o que tem levado a propor às agências de fomento a criação de bolsas de manutenção para atender a esses alunos. 



\section{Avaliação}

\subsection{Avaliação a Serviço da Aprendizagem Matemática}

Quando direciona-se o olhar a um aluno, e esse olhar determina a ação de trabalho para o desenvolvimento da aprendizagem do mesmo ou do grupo no qual ele está inserido, este ato intencional é uma avaliação para a aprendizagem. Sendo formal ou não, a avaliação da aprendizagem corrobora para a formação de um indivíduo. Se utilizada de forma errônea, pode causar a evasão escolar e até caracterizar os indivíduos, levando-os à exclusão pelos seus pares.

As notas altas também podem resultar em exclusão, pois os alunos, ao receberem elogios, parecem possuir padrões inalcançáveis ao grupo ao qual pertence. Em contrapartida, as notas baixas podem destruir a autoimagem dos estudantes, por se considerarem fora de um padrão esperado. Tanto uma como a outra classificação estigmatizam e podem conduzir ao bullying na escola.

Estes são resultados informais de uma avaliação classificatória no foro do aluno, que o rotulam no meio social de forma negativa, obtendo ou não resultados numéricos positivos.

Na outra face, ao verificar resultados abaixo do esperado, o professor já classifica o que pode ser ensinado e/ou como pode ensinar, determinando o que será apresentado para suas diversas turmas. Esse é o traço da avaliação informal no processo de ensinoaprendizagem.

Com a OBMEP não é diferente, com questões desafiadoras e fora do padrão livresco, seus resultados numéricos denotam um senso de "dia perdido de aula" na escola. O grupo escolar apresenta constantemente questionamentos do tipo: por que se deve parar a escola para uma atividade que revela o baixo nível de requisitos apresentados pelos alunos? Por que um gasto excessivo com reproduções de materiais os quais os alunos nem se dão o trabalho de ler?

Aqui se veem questionamentos de visões construídas na avaliação classificatória, que, informalmente, vão reger o trato nas atividades de aplicação das provas da primeira fase da Olimpíada na escola e até mesmo no uso desta atividade no âmbito escolar.

O processo de avaliação, formal ou informal, não deve ser norteador do trabalho docente se não for embasado em objetivos claros. Assim a avaliação deve estar servindo à aprendizagem almejada nos objetivos educacionais e a intencionalidade deve ser a raiz do avaliar. Dependendo do objetivo traçado, os métodos e a temporalidade de avaliação 
deverão se adaptar ao grupo de indivíduos e às suas necessidades. Logo, a avaliação deverá ser vista como produto dos objetivos.

Em contrapartida, a avaliação traz um feedback para uma reconstrução dos objetivos, ampliando-os ou até mesmo alterando-os. É uma relação biunívoca avaliação/objetivos, na qual os resultados apresentados por alunos geram modificações no processo metodológico de ensino-aprendizagem, inclusive nos próprios objetivos. E os objetivos regem o processo avaliativo em busca de resultados.

De acordo com Freitas, os objetivos orientam o caminho a seguir, contribuindo na percepção se as atividades foram cumpridas a contento. E a avaliação é a concretização do idealizado nos objetivos, permitindo a análise ideal e real. Além disso, "os objetivos, sem alguma forma de avaliação, permaneceriam sem nenhum correlato prático que permitisse verificar o estado concreto da objetivação" (FREITAS, 1995 apud VILLAS-BOAS, 2014, p. 95).

Cabe neste momento um olhar conceitual para a avaliação para o melhor entendimento dessa relação avaliação-objetivos.

\title{
2.2 Rompendo os Conceitos Avaliativos
}

A avaliação classificatória é o produto da avaliação somativa na escola. O professor australiano Royce Sadler define:

\begin{abstract}
que a avaliação somativa apresenta o balanço do desempenho do aluno ao final de um período de estudos, geralmente com o propósito de certificação (...) é empregada para medir o que foi aprendido ao final de determinado período; para promover os alunos; para assegurar que eles alcancem os padrões de desempenho estabelecidos para conclusão de cursos, para exercer certas ocupações ou para selecionar os que prosseguirão os estudos (SADLER, 1989 apud VILLAS-BOAS, 2006).
\end{abstract}

Ou seja, a avaliação classificatória é definida por mensuração nos períodos de estudos, denota a posição do estudante em face ao currículo escolar e a "medida" do seu aprendizado. Essa é utilizada por gestores educacionais ao requererem subsídios governamentais, na elaboração de históricos escolares e também na própria OBMEP, que tem o caráter classificatório competitivo.

Conceitualmente, busca-se fugir da avaliação classificatória por medir e nesta mensuração determinar o quanto foi aprendido, mas, na prática, é difícil romper com essa forma de avaliar, pois o docente traz para sua sala de aula todos os processos avaliativos que aprendeu em sua formação, e essa formação não é apenas a acadêmica, mas em toda sua vida escolar. Como romper com a prática avaliativa, se o método tradicional levou este profissional a uma vida acadêmica próspera? 
Segundo Sadler (1989 apud VILLAS-BOAS, 2006), "o que diferencia a avaliação somativa da formativa é o propósito e o efeito, e não o momento da sua realização", ou até mesmo a sua forma. Uma prova como a OBMEP é classificatória, mas se agregada a esta propósitos de construção da aprendizagem durante a sua realização, o aluno ou o professor tornam-se foco da construção de habilidades. E com esse enfoque soma-se, à classificação, um processo de formação.

A avaliação formativa, segundo Villas-Boas (2014), toma o aprendiz como sua própria referência de medida de aprendizado. É o momento onde o docente, de maneira frequente e interativa, analisa o progresso dos alunos, para identificar quais as suas habilidades e competências e o que falta construir, de forma a orientar e/ou reorientar sua ação pedagógica, levando em consideração as diferenças inerentes ao trabalho com cada aluno, até mesmo a temporalidade individual de aprendizado.

Segundo a mesma autora, com a avaliação formativa, "pode-se atingir os objetivos da aprendizagem permanente, seja elas: a promoção de desempenho de alto nível; a adoção de tratamento equânime dos resultados da avaliação dos alunos; a construção de habilidades para o aprender a aprender" (VILLAS-BOAS, 2014).

Os objetivos apontam o estado final e o estado final está em contradição com o estado real do aluno, o que deve criar motivação, gerar movimento. A avaliação é instrumento dessa superação. Aponta o estado real e serve de ponto de referência para o aluno contrapor-se ao que é esperado em termos de objetivos. Porém, esse processo deve ser assistido de forma a garantir os elementos necessários para a superação das dificuldades dos alunos [...] (FREITAS, 1995).

Nessa perspectiva formativa, o professor facilitador da aprendizagem pode ser considerado um correlacionador de feedbacks e objetivos, reconhecendo e descrevendo o desempenho desejável de seus alunos, indicando o que pode ser melhorado até que o próprio aluno assuma o papel correlacionador. O professor oferece inicialmente o caminho em busca dos objetivos até o alcance do auto-monitoramento pelo aluno, onde este é capaz de gerar informação necessária para caminhar para aprendizagem, segundo Sadler:

A avaliação formativa é a que engloba todas as atividades desenvolvidas pelos professores e seus alunos, com o intuito de fornecer informações a serem usadas como feedback para reorganizar o trabalho pedagógico.

O feedback é o elemento-chave na avaliação formativa: diz respeito à informação, ao próprio aluno, a quão bem-sucedido ele foi no desenvolvimento do seu trabalho.

Poucas habilidades físicas, intelectuais e sociais podem ser desenvolvidas satisfatoriamente falando ao aluno sobre elas. A maioria requer a prática em ambiente apoiados, que favoreça o entrelaçamento de feedbacks (SADLER, 1989 apud VILLAS-BOAS, 2014, p. 39-40). 
Para Hadji, a avaliação formativa tem como ponto forte a característica de informar aos envolvidos no processo de ensino os objetivos alcançados e potenciais de desenvolvimento em ambos os atores: professores e alunos.

\begin{abstract}
O professor será informado dos efeitos reais de seu trabalho pedagógico, poderá regular sua ação a partir disso. O aluno, que não somente saberá onde anda, mas poderá tomar consciência das dificuldades que encontra e tornar-se-á capaz, na melhor das hipóteses, de reconhecer e corrigir ele próprio seus erros (HADJI, 2001, p. 20).
\end{abstract}

De acordo com Villas-Boas (2014), para o alcance do auto-monitoramento é necessário que o aluno, motivado pelo professor:

1. saiba quais os objetivos de aprendizagem que devem ser alcançados no processo de aprendizagem;

2. seja capaz de definir o quão distante ele está desta meta;

3. se torne agente, reduzindo a distância entre o nível em que ele se encontra e a meta de aprendizado.

Um componente importante nesse processo formativo é a avaliação informal que ocorre quando o professor dá ao aluno a orientação e o suporte que ele necessita, demonstrando interesse pela aprendizagem individual; sem demonstrar preferências e usando as dificuldades como suporte de amadurecimento de conceitos.

Tratando da avaliação informal, Freitas aponta que

Professores e alunos defrontam-se na sala de aula construindo representações uns dos outros. Tais representações e juízos orientam novas percepções, traçam possibilidades, estimam desenlaces, abrem ou fecham portas e, do lado do professor, afetam o próprio envolvimento deste com os alunos, terminando por interferir positiva ou negativamente com as estratégias de ensino postas em marcha na sala de aula. É aqui que se joga o sucesso ou o fracasso do aluno - nesse plano informal e não no plano formal. De fato, quando o aluno é reprovado pela nota, no plano formal, ele já tinha sido, antes, reprovado no plano informal, no nível dos juízos de valor e das representações do professor - durante o próprio processo (FREITAS, 2002 apud VILLAS-BOAS, 2014, pg. 45).

Como citado, a avaliação informal está entrelaçada com a avaliação formal, onde esta tem como exemplos - provas, relatórios, exercícios diversos, produção de textos e outros - e é caracterizada pela documentação que serve de base para o olhar do docente. Tradicionalmente utilizada para classificar, mas são os instrumentos que constroem fontes para o julgamento do professor, que, ao pensar formativamente a aprendizagem de seu aluno, verifica o distanciamento do mesmo com o objetivo esperado e toma atitudes de 
orientação no processo pedagógico que visem a avaliação para aprendizagem, mesmo que haja um número em seu topo.

Villas-Boas (2014), em suas pesquisas, emprega a expressão "avaliação para aprendizagem" introduzindo um novo paradigma para a avaliação.

Porque a avaliação para aprendizagem contribui para a reorganização do trabalho pedagógico, ampliando a aprendizagem de professores. E, em sentido mais amplo ainda, chega-se ao desenvolvimento da escola. Essa perspectiva constrói cultura de avaliação formativa na escola (VILLASBOAS, 2014, p. 57).

Ao docente cabe a função de cuidar de todo o desenvolvimento da avaliação, que poderá incluir (BRASIL, 2000):

i. A definição dos objetivos educacionais que orientarão o trabalho pedagógico que será desenvolvido;

ii. a delimitação dos conteúdos que serão abordados e como serão abordados;

iii. o envolvimento dos alunos no processo avaliativo;

iv. a definição dos procedimento/instrumentos de avaliação;

v. a análise dos resultados e feedback dos mesmos aos alunos; e

vi. as tomadas de atitudes a partir dos resultados apresentados pelos alunos.

Essa autonomia do professor frente a avaliação é dada pela hierarquia do sistema educacional, que também dá subsídios para o processo de avaliação da aprendizagem. O docente, embora autônomo, deve basear seu trabalho no PPP - Projeto Político Pedagógico, documento construído por toda comunidade escolar que se baseia na avaliação institucional, na LDB - Lei de Diretrizes e Bases, nos PCN - Parâmetros Curriculares Nacionais e em outras diretrizes nas esferas municipais, estaduais e nacionais.

Como dito acima, as posturas de avaliar do docente no âmbito da sala de aula estão presentes na esfera educacional, que se apresenta em três níveis, segundo Freitas, que se integram com o objetivo de analisar e discutir a qualidade de ensino-aprendizagem: "avaliação em larga escala em redes de ensino; a avaliação institucional da escola; e a avaliação da aprendizagem em sala de aula" (FREITAS, 2014, p. 10).

Ressalta-se a importância desses níveis para entender que o tema avaliação abrange vários componentes. Desde o Estado e suas políticas - confrontos de resultados com outros países e declarações de metas construídas por órgãos internacionais - perpassando pela escola até chegar a sociedade e seus anseios. 
No tocante à avaliação institucional, esta tem como objetivo criar indicadores que contribuam para a reconstrução do ambiente escolar, em todos os seus níveis, desde o espaço físico e intenções pedagógicas até os seus atores, do gestor até o aluno. A avaliação institucional da escola "é um processo que envolve todos os seus atores, com vistas a negociar patamares adequados de aprimoramento, a partir dos problemas concretos vivenciados por ela" (FREITAS, 2014, p. 35).

Os resultados da escola na OBMEP podem ser utilizados neste nível de forma a eleger procedimentos e projetos que contribuam para um resultado mais significativo nas avaliações da competição, verificando o distanciamento da aprendizagem dos alunos ao que se é esperado na realização de tais avaliações e também questionando o envolvimento dos profissionais da instituição na olimpíada.

Estando um nível acima, de acordo com Freitas (2014), a avaliação externa em larga escala ou avaliação de redes visa ao levantamento de dados que contribuam a gerar informações que possam descrever a realidade educacional dos estados, municípios e, por sua vez, do país. São realizadas pelos sistemas educacionais ou de ensino, normalmente com institutos de pesquisa, órgãos governamentais ou outras entidades vinculadas à educação e ao seu funcionamento.

Para Freitas, esse tipo de avaliação "quando conduzida com metodologia adequada pode trazer importantes informações sobre o desempenho dos alunos, dados sobre os professores, condições de trabalho e funcionamento das escolas de uma rede" (FREITAS, 2014, p. 47). Como exemplo temos o SINAES, o Saeb e a Prova Brasil.

Os resultados obtidos pelo Relatório de Acertos e Informações Gerais RAIG (Anexo A) ajudam na identificação do trabalho que o professor desenvolve com seus alunos no tocante a OBMEP. Após a realização da primeira fase da OBMEP, o coordenador do evento na escola é convidado a responder a um questionário sobre os envolvidos no processo, quantificando notas dos participantes e verificando o uso dos recursos disponibilizados pelo organizador da competição destinados aos educadores.

Em 2013, 35.062 unidades escolares enviaram o RAIG com devolutivas sobre a OBMEP, representando 74,4\% das escolas cadastradas. Nesse mesmo ano, verificou-se que 48,5\% das escolas afirmam desenvolver atividades extracurriculares de Matemática. Entre estas, 21,8\% indicam a realização de gincanas e competições internas, $20,2 \%$ de grupos de estudos e 1,2\% das unidades escolares relatam a criação de Clubes de Matemática. Destaca-se ainda que, 10,9\% afirmam realizar outras atividades, desde atividade de reforço, treinamentos para OBMEP até projeto como o Superação Jovem, em parceria com o instituto Ayrton Senna (RAIG 2014).

Neste tocante, Villas Boas acrescenta que a avaliação do desempenho dos alunos em larga escala: 
Embora sejam necessárias, estas iniciativas não tem sido acompanhadas de ações que as associem adequadamente ao trabalho de toda a escola e ao trabalho conduzido pelo professor em sala de aula. Avaliar é preciso. Mas de forma que contribua com a melhoria do trabalho escolar (VILLAS-BOAS, 2014, p. 10).

\subsection{Avaliação e Educação Matemática}

A ação avaliativa para a aprendizagem é um romper de paradigmas, pois o ato de medir é muitas vezes confundido com avaliar, em que o primeiro implica determinar a extensão de uma característica pertencente a um indivíduo ou a um objeto e a segunda significa comparar uma medida com um padrão e emitir um julgamento sobre a comparação.

Como avaliar envolve um julgamento, são envolvidas também concepções intrínsecas do indivíduo: crenças, valores, princípios, teorias e/ou conceitos. Assim, pode-se confirmar que avaliar é mais amplo que apenas medir e que na prática pode-se usar instrumentos avaliativos como meios para o ato de avaliar a aprendizagem dos alunos e não apenas para medir ou quantificar. Além disso, pode-se questionar se o instrumento utilizado, de fato, revela o que o aluno apreendeu.

Os PCN pautados numa perspectiva de ensino-aprendizagem da Matemática que busca conduzir os alunos a experiência de situações que os levem a uma aprendizagem significativa e prazerosa, afirma que:

[...] para tanto, é importante que a Matemática desempenhe, equilibrada e indissociavelmente, seu papel na formação de capacidades intelectuais, na estruturação do pensamento, na agilização do raciocínio dedutivo do aluno, na sua aplicação a problemas, situações da vida cotidiana e atividades do mundo do trabalho e no apoio à construção de conhecimentos em outras áreas curriculares.

Os resultados expressos pelos instrumentos de avaliação, seja eles provas, trabalhos, postura em sala de aula, constituem indícios de competências e como tal devem ser considerados. A tarefa do avaliador constitui um permanente exercício de interpretação de sinais, de indícios, a partir dos quais manifesta juízos de valor que lhe permitem reorganizar a atividade pedagógica (BRASIL, 2000, V.3 p. 29).

Nesses apontamentos presentes nos PCN relativos à avaliação, os instrumentos avaliativos devem ser embasados na intencionalidade de desempenho de habilidades e competências que contemplem o conhecimento Matemático, com toda a sua abstração, associado a suas aplicações no cotidiano da sociedade, contribuindo pelo melhor entendimento de mundo pelo estudante.

O professor de Matemática deve manter o foco no objetivo principal do ensino, que é a aprendizagem. Deve questionar constantemente se as atividades pedagógicas propostas 
por ele, e isto inclui a avaliação, estão contribuindo para a formação do aprendiz como um todo ou apenas focadas em classificar.

Com isso, vê-se que na visão de avaliação para a aprendizagem, o professor é convidado a reconhecer a avaliação como parte do processo de ensino e aprendizagem e a repensar as sua atitudes frente aos seus métodos pedagógicos, usando o princípio de organização e reorganização do ato de ensinar, não podendo este ser reduzido a aplicações de atividades avaliativas de forma isolada e dissociada do processo.

Os PCN (BRASIL, 2000) ressalta, ainda, a necessidade de o professor manter-se atento quanto ao alcance dos objetivos pré-determinados, para que possa, se necessário, reorganizar as atividades pedagógicas a tempo de alcançar os objetivos. Infere-se com isso que avaliação da aprendizagem Matemática deve acontecer ao longo do processo de ensinoaprendizagem tendo o professor que lançar mão de diversos procedimentos/instrumentos e adaptar essa trajetória tendo como foco o aluno.

Atividades com caráter avaliativo devem auxiliar na investigação dos fatores que contribuem de forma positiva e negativa para o desenvolvimento do saber matemático, não só para auxiliar o professor em sua tarefa de ensinar, mas em esclarecer para os alunos seu desempenho diante do objetivo de aprender, devem levá-los a um auto-monitoramento das suas conquistas e revelá-los o caminho que ainda falta percorrer.

A prática avaliativa que visa à memorização de teoremas e à reprodução de técnicas de resolução de exercícios acaba por se limitar a procedimentos que não vão além de provas, tão conhecidas como classificatórias e excludentes. Professores e alunos precisam enxergar no cotidiano escolar várias possibilidades de aprendizagem. A avaliação deve ser entendida como uma atividade capaz de proporcionar oportunidades de aprender. Abrantes corrobora com este pensamento ao dizer:

\footnotetext{
Ver as tarefas de avaliação como fontes de aprendizagem implica que elas requerem atividades interessantes e significativas. Além disso, elas devem proporcionar aos alunos novas oportunidades para aprender, para melhorar e para refletir sobre seu próprio trabalho (ABRANTES, 1995, p. 15).
}

Na avaliação da aprendizagem Matemática, as atenções devem estar voltadas para todos os lados, todas as atividades desenvolvidas pelos alunos constituem-se como elementos de investigação da aprendizagem Matemática. Observar e analisar as estratégias traçadas pelos alunos quando colocados frente a uma situação-problema mostra-se como essencial no processo investigativo da avaliação. Estar atento ao plano de ação do aluno requer que o professor, em especial, considere os registros escritos desse aluno.

Para enriquecer a análise de registros escritos, o professor pode ouvir o aluno para melhor entender seu procedimento ao resolver uma situação Matemática. Essa prática 
serve tanto para orientá-lo no processo de formalização, quanto na organização da lógica de resolução. Isso se justifica pois algumas passagens na resolução de uma situação-problema não são manifestas na escrita e estas podem esclarecer informalmente o porquê do caminho utilizado.

Corroborando com essa ideia, o processo de avaliação em Matemática, segundo Buriasco, deve evidenciar, entre outras coisas:

- a interpretação dada, diante a resolução de uma questão;

- as opções feitas durante a resolução;

- os conhecimentos matemáticos utilizados;

- se utilizaram a Matemática que é vista nas aulas; e

- a forma de comunicação Matemática, comprovando sua capacidade em se expressar, oralmente ou por escrito (BURIASCO, 2002 apud BURIASCO; SOARES, 2012, p. 114).

Vasconcellos (1998) aponta três dimensões que considera essenciais para a concretização da avaliação da aprendizagem: a intencionalidade, o conteúdo e a forma. Em acordo com a perspectiva apresentada por este autor, estas dimensões serão discutidas a seguir com o intuito de orientar o desenvolvimento das práticas avaliativas que perpassam a escolha dos procedimentos/instrumentos avaliativos.

\subsubsection{Intencionalidade - o objetivo ao avaliar}

É a ação que fundamenta a ação docente ao avaliar, é o estabelecimento do que se pretende com a avaliação. O professor estará traçando a função da avaliação que poderá variar entre classificatória e/ou formativa.

Vasconcellos (1998) considera este o momento determinante da avaliação, segundo o autor a intencionalidade que o professor atribui à avaliação no seu cotidiano influirá em todo seu desenvolvimento até o resultado.

\subsubsection{O conteúdo - o objeto de avaliação}

Aqui o termo conteúdo não se refere àquele estruturado pelos itens do conhecimento do currículo, mas ao que será observado para fazer juízo de avaliação. Mas sim a delimitação do objeto de avaliação que norteará o trabalho docente ao longo do processo avaliativo.

Aquele trabalho em sala, como parte constituinte da aprendizagem, provavelmente será objeto de análise, entretanto sabe-se que durante a avaliação diversas situações poderão se apresentar levando o professor a ficar atento também a outras dimensões da 
avaliação. Podem ser incluídas no processo de verificação da aprendizagem: a postura do estudante, antes e durante as atividades avaliativas; as estratégias de resolução dos exercícios; a interação com os colegas e professor, e outras fontes informais.

Na verdade, o conteúdo avaliado é o foco que o avaliador dará sobre a situação avaliativa como um todo. São todas as características que este último julgará para dar seu veredito final.

\subsubsection{Forma - os procedimentos/instrumentos de avaliação}

Os instrumentos escolhidos para avaliação deverão adequar-se ao objetivo e ao objeto de avaliação. Se bem escolhidos e elaborados, poderão auxiliar de modo significativo na investigação, análise e regulação do processo para que a aprendizagem seja conseguida. De acordo com Vasconcellos,

O como avaliar, a qualidade do instrumento também é importante, pois a própria transformação da postura do professor pode ficar comprometida se ele se prender a instrumentos/formas de avaliar tradicionais (estando em processo de mudança, precisará de um bom instrumento que lhe ajude a perceber como está indo seu intento) (VASCONCELLOS, 1998, p. 124).

As escolhas quanto aos procedimentos/instrumentos de avaliação (como avaliar) apresenta-se aqui como último passo na elaboração e organização das práticas avaliativas, tendo em vista que definir os objetivos (intenções) e determinar o que se quer avaliar (conteúdo) constituem-se tarefas primeiras em busca de uma avaliação preocupada em subsidiar e informar acerca da aprendizagem e desenvolvimento dos alunos.

Cabe ressaltar que a mudança da avaliação com o enfoque para a aprendizagem Matemática não tem como fator determinante as práticas. "A questão principal não é a mudança de técnicas; passa por técnicas" (VASCONCELLOS, 1998, p. 41), portanto fazse necessário ater-se apenas a forma, mas na intencionalidade do instrumento investigado.

Muito se diz sobre o uso de portfólios, até mesmo virtuais, como instrumental de avaliação pois com estes se apoiam em uma documentação e uma análise do processo de aprendizagem de forma contínua em busca de uma avaliação formativa. No entanto, uma prova escrita pode ser empregada de significados no avaliar que rompe com o seu uso classificatório e pode ser usada como instrumento investigativo que leve a uma formação do educando cheia de significados. O procedimento é que qualifica o instrumento, ou seja, o uso transforma-o em uma avaliação para a aprendizagem.

A seguir serão apresentadas algumas sugestões de elaboração desse instrumento, que podem ampliar e auxiliar o professor na sua ação como avaliador. A intenção não é apresentar receitas prontas de procedimentos/instrumentos avaliativos, mas apresentar 
propostas para que o elaborador/professor as utilize ou adapte a sua prática, podendo ainda servir como ponto de partida para o surgimento de outros nortes na construção de uma avaliação educacional no nível de sala de aula, ou até mesmo de larga escala, como a OBMEP.

\title{
2.4 Um Instrumento para a Aprendizagem
}

Antes de discorrer sobre os procedimentos/instrumentos apresentados como propostas a serem utilizadas no processo de avaliação, faz-se necessário enfatizar que o trabalho pedagógico pensado para o ensino da Matemática deve ser organizado a partir de situações-problema, pois estas são consideradas ferramenta metodológica capaz de construir e mobilizar conhecimentos e ainda dar significado às atividades matemáticas desenvolvidas em sala de aula.

Nessa perspectiva, os PCN apontam a "resolução de problemas como eixo organizador do processo de ensino-aprendizagem" e, ainda, que "essa opção traz implícita a convicção de que o conhecimento matemático ganha significado quando os alunos têm situações desafiadoras para resolver e trabalham para desenvolver estratégias de resolução" (BRASIL, 2000, p. 40).

Se as situações-problema são o basilar do ensino em Matemática, estas devem ser utilizadas em qualquer instrumento avaliativo. Os procedimentos/instrumentos são as ferramentas e/ou os meios utilizados para auxiliar o processo de avaliação da aprendizagem Matemática. Portanto, faz-se necessário que se tenha certa diversidade de instrumentos para que a cada momento seja possível lançar mão de ferramentas adequadas a fim de contribuir com o sucesso da avaliação. Ao encontro disso, Correia corrobora:

\begin{abstract}
As metodologias utilizadas para acompanhar o desenvolvimento do raciocínio e aquisição de conhecimentos devem ser diversificadas e utilizadas em todos os momentos do processo educativo. A variedade de instrumentos fornecerá ao professor, ao aluno e aos pais um retrato mais próximo do que está ocorrendo em termos de raciocínio e aprendizado matemático (CORREIA, 2010a, p. 36).
\end{abstract}

No tocante aos instrumentos, não será relatado a fundo os outros tipos além da prova escrita e seu uso, mas de forma nenhuma quer se restringir ao uso apenas deste ferramental. Pretende-se apenas dar uma visão mais ampla de seu uso e ressignificar esta prática.

A prova torna-se um mecanismo equivocado quando é usada como único procedimento de avaliação, assumindo função classificatória. Isso acontece sempre que os resultados por ela fornecidos servem tão somente para atribuição de nota, sem que o aluno tenha chance de aprender o que ainda não aprendeu. Na perspectiva classificatória, a nota que resulta 
da prova é mantida. Ao contrário, na perspectiva formativa, por meio dela constata-se o que cada aluno aprendeu e o que ainda não aprendeu, para que o trabalho pedagógico seja reorganizado e a aprendizagem seja garantida (VILLAS-BOAS, 2014, p. 91).

O cuidado ao elaborar a prova poderá definir seu papel no processo de ensinoaprendizagem. Ao ser elaborada, o professor deverá cuidar para que as questões que serão respondidas pelos alunos possam, além do resultado final, lhe trazer outras informações. Estas podem esclarecer acerca do raciocínio, do domínio de conceitos matemáticos, do poder de interpretação e da leitura da linguagem matemática que o aluno detém.

Durante a elaboração de itens, pode-se escolher qualquer formato: múltipla escolha, certo ou errado, resposta fechada, resposta construída e/ou dissertativa, levando estudantes a conhecer diversos formatos de testes, os quais irão se defrontar durante a vida. Após sua realização, o professor facilitador apresenta o feedback para os alunos e pode retomar a aprendizagem com diversas abordagens. Segundo Villas Boas, cabe ao professor:

[...] usar a prova com criatividade. Por exemplo: após sua realização pelos alunos e a análise feita por ele, as provas são devolvidas para que, por meio de orientação e de novos estudos, sejam revistas as respostas que demonstram essa necessidade. O que importa não é nota, mas aprendizagem (VILLAS-BOAS, 2014, p. 92).

A prova deverá explorar os conhecimentos matemáticos dos alunos durante e após sua aplicação. Deverá levar os alunos a analisarem e discutirem seus procedimentos de resolução, possibilitando que eles tomem consciência do andamento da sua aprendizagem e busquem o auto-monitoramento.

Com esse intuito, além de avaliações realizadas em dupla e em grupo, há a proposta de avaliação pelos pares, onde após apreciação pelo docente, os colegas trocam atividades entre si, verificam as resoluções apresentadas fazendo um comparativo entre as respostas. Após essa etapa, eles apresentam de forma escrita ou verbal o seu parecer, mostrando o distanciamento entre as respostas dadas e as esperadas.

Esta avaliação por pares eleva a participação do estudante no processo de aprendizagem e faz com que este tome consciência do seu distanciamento da meta esperada, colaborando também para a construção do auto-monitoramento.

O feedback advindo de um grupo de colegas pode ser mais bem-aceito do que o individual. Esse tipo de avaliação permite a participação de alunos e aumenta a comunicação entre eles e o professor, sobre sua aprendizagem. Ao possibilitar aos alunos reconhecerem suas próprias necessidades, comunicando-as ao professor, este tem o seu trabalho facilitado e um tempo maior para auxiliar aqueles que precisam de sua atenção. (...) o professor pode dedicar-se a observar o desenvolvimento das atividades, 
refletir sobre elas e fornecer intervenções necessárias (VILLAS-BOAS, 2014, p. 49).

O registro escrito em questões discursivas ajuda muito na tarefa do professor em formar juízo de valor, pois demonstra as fragilidades na resolução das situações propostas. Estas fragilidades são entendidas como erros, assunto a ser abordado com mais detalhes no Capítulo 6. No entanto, as questões de múltipla escolha, se bem elaboradas, também podem demonstrar essas fragilidades. Nesse caso, a utilização de distratores plausíveis pode fornecer feedback de grande valia para docente e discente. O conceito de plausibilidade será explorado a seguir. 



\section{Instrumento Avaliativo e a Psicometria}

\subsection{Teoria de Resposta ao Item}

Ao apresentar uma perspectiva de avaliação da aprendizagem matemática que evoca práticas dinâmicas e significativas para o processo de ensino-aprendizagem ao longo de todo do período escolar, emerge questionamentos acerca de como estreitar a distância entre toda a teoria apresentada e a prática em sala de aula.

A terminologia Engenharia de Itens não é considerada ainda no meio científico, por ser muito moderna, mas neste estudo este termo ajuda a demonstrar a importância de se construir bons itens para ampliar o uso de avaliações escritas em avaliações formativas. Esta é a contribuição dos trabalhos de Rabelo em avaliações em larga escala. Os conceitos apresentados são embasados no modelo da Teoria de Resposta ao Item (TRI) e nos trabalhos desenvolvidos por Rabelo (RABELO, 2013).

Para justificar a construção dos itens é importante ressaltar o que vem a ser a Teoria de Resposta ao Item: um conjunto de modelos matemáticos que tem por objetivo mensurar certas habilidades ou características de uma pessoa - traços latentes - a partir das respostas dadas por ela a um conjunto de itens previamente definidos. Nesse modelo, analisa-se a probabilidade de ser dada uma determinada resposta em função de certas características do item.

Assim, quanto maior a habilidade do respondente maior será a probabilidade de ele fornecer a resposta correta. Tomando as respostas encontradas e a escala de proficiência, determina-se a habilidade do mesmo. Esta mensuração de mão dupla é decorrente de modelos matemáticos que relacionam as variáveis envolvidas nessa situação.

O modelo utilizado no ENEM, por exemplo, é o modelo logístico de 3 parâmetros, que permite que seja estimado o traço latente do candidato a partir de uma relação que fornece a probabilidade de um indivíduo acertar o item, levando em consideração:

1. a dificuldade do item,

2. a discriminação e a

3. probabilidade de acerto ao acaso.

Para se construir um item, de acordo com a TRI, é importante que se preconize duas características importantes de um item: a unidimensionalidade e a independência local. 
A unidimensionalidade é a hipótese segundo a qual há apenas uma aptidão dominante responsável pelo desempenho em um conjunto de itens de um teste (RABELO, 2013). Já a hipótese de independência local assume que - para uma dada habilidade, as respostas aos diferentes itens da prova são independentes (RABELO, 2013), ou seja, mantidas constantes as aptidões que afetam o teste, o desempenho de um indivíduo em um item não interfere no seu desempenho em outro item (RABELO, 2013). Isso não quer dizer que os itens não possam estar correlacionados, mas que cada indivíduo dá respostas independentes para cada item do teste.

O acerto ao acaso, ou chute, ocorre principalmente com os itens nos quais indivíduos de baixa aptidão não conhecem a resposta correta, mas arriscam qualquer resposta, e acabam por acertar o item. Nesse caso, quando se constrói um item deve-se considerar que a resposta correta não deve ter características de atração do respondente, pois pode levar pessoas que não detêm determinada habilidade a acertar um item, não demonstrando, assim, as habilidades reais do aluno diante da situação proposta e nem contribuindo para que o item seja discriminativo.

A discriminação é concebida como a capacidade do item de diferenciar indivíduos com diferentes habilidades. Na TRI, é definida como o poder do item para diferenciar indivíduos com magnitudes próximas da habilidade que está sendo aferida. Já a proficiência é a característica do respondente em acertar o item proposto, desde que ele mobilize as habilidades esperadas na interpretação e na resolução do item.

A partir destes apontamentos, deve se considerar que para alcançarmos uma avaliação escrita que se encontre em um ambiente construtivista, é necessário que a construção e a elaboração de itens seja bem planejada e metódica, exigindo a definição de passos de construção com rigor e metodologia própria. Para esse fim, sugere-se o uso da Engenharia de Construção de Itens, apresentada por Rabelo para a elaboração de avaliações de larga escala, mas que pode e deve ser utilizada por docentes em suas avaliações no ambiente de sala de aula.

\subsection{Teoria Clássica dos Testes}

Para que um teste avalie com amplitude pedagógica, é necessário que os itens, presentes no mesmo, contemplem as habilidades e competências a serem avaliadas; revelem os processos usados pelo educando para responder o teste e se tornem instrumentos de feedback tanto para o professor elaborador quanto para que o aluno se automonitore.

O elaborador do item tem que se preocupar com os objetivos prévios e as ações que poderá desenvolver com os resultados em mãos. Se essa função de elaborador for embasada com uma análise do instrumento de avaliação, a metodologia de avaliação escrita poderá propiciar uma avaliação formativa significativa. 
Para respaldar o trabalho pedagógico, há pressupostos teóricos de análise quantitativa que podem ajudar na construção dos itens tanto na Teoria de Resposta ao Item (TRI) quanto na Teoria Clássica dos Testes (TCT), ambas confirmam análises qualitativas dos pressupostos utilizados para responder o item. Ambas as análises, qualitativas e quantitativas, visam avaliar a validade, a fidedignidade e a objetividade dos testes. "De forma geral, ambas fornecem informações relevantes para tomada de decisão dos itens que comporão o teste definitivo, bem como sugerir ajustes na formulação de itens (CONDé, 2008, p. 33).

A TRI complementa as limitações da TCT, mas é embasada nos primeiros dados gerados nesta teoria. Antes dos dados serem calibrados na TRI, é necessário que se determine porcentagens de acerto e o coeficiente bisserial do item, para evidenciar problemas iniciais do item em estudo. Assim, alguns elementos da TCT são importantes na interpretação dos resultados de um teste e serão abordados aqui.

Como visto anteriormente, a Teoria de Resposta ao Item contribui com representações quantitativas que norteiam o entendimento da análise qualitativa do item. De forma menos específica, os procedimentos de análise da TCT também embasam estudos qualitativos, mas em relação ao teste. Esta teoria tem em sua metodologia a comparação do indivíduo ante o teste como um todo.

Segundo Fletcher (2010), a Teoria Clássica tem sua origem no modelo de escore verdadeiro e de erro apresentado pelo psicólogo britânico Charles Spearman (1863-1945), em 1904.

O modelo da TCT é embasado em dados empíricos coletados de um conjunto de itens agrupados. O teste é construído por meio da seleção de uma amostra de itens coletados de um universo que parece medir um dado construto. Essa maneira de construir instrumentos psicométricos está fundamentada na ideia de que existe, para cada construto, um conjunto indefinido de itens do qual uma amostra é extraída para construir o teste. Na TCT, os parâmetros do item e da habilidade são dependentes da amostra e do teste.

A validade na TCT consiste na verificação da hipótese de que o teste é capaz de predizer um critério externo, o qual é representado por comportamentos. Assim, a demonstração da validade é uma questão de legitimação do instrumento em relação ao erro de estimação, ou seja, é a verificação da magnitude do escore verdadeiro que é concebido como representante legítimo do traço latente (RODRIGUES, 2006, p. 52).

Em uma prova de múltipla escolha, o desempenho medido consiste das respostas corretas do examinado aos itens de prova, onde este mobiliza habilidade diante o conceito solicitado - dado construto. A resposta certa pode ser representada pelo valor 1, e, para os erros, pelo valor 0. A partir de cada item de prova, acumula-se um conjunto de respostas 
na forma de uma sequência de uns e zeros, $001101011010 \ldots$, o que corresponde ao vetor de respostas $x=\left(x_{1}, x_{2}, \ldots, x_{L}\right)$, em que $L$ é o número total de itens na prova.

A partir desta representação vetorial, destaca-se o primeiro índice numérico a ser apresentado pela TCT - o escore bruto. Fletcher aponta que o número total de acertos na prova - escore bruto, pode ser estipulado como a regra numérica a ser aplicada no ato da mensuração. Nos termos mais gerais, a escala de uma prova pode ser definida por uma fórmula de escores $X$, conforme apresentado na Equação 3.1,

$$
X_{i}=\sum_{j=1}^{L} \omega_{j} x_{i j}
$$

onde $x_{i j}=1$, quando o item $j$ for acertado pela pessoa $i$ e $x_{i j}=0$, caso contrário. E quando $\omega=1$, a fórmula proporciona o total de acertos, ou seja, o escore bruto obtido pelo estudante. Quando o valor de $\omega$ permanece constante, com peso igualitário para todos os itens, obtém-se o modelo linear da chamada Teoria Clássica de Testes.

Um parâmetro importante a ser analisado, utilizando-se a TCT, é a dificuldade dos itens $(D)$ que compõem um teste. Esta pode ser definida como a porcentagem de examinandos que respondem corretamente aos itens. Ou seja, a dificuldade de cada item é determinada pela razão entre o número de pessoas que acertaram o item e o número total de pessoas que o responderam.

Associando-se os índices gerados por essa análise às informações pedagógicas do item, podem-se obter dados que sugerem dificuldades dos alunos, em termos das competências que deveriam ter construído ou das aprendizagens esperadas.

Há uma parametrização numérica em que 0 significa que nenhum estudante acertou e 1 significa que todos os estudantes acertaram. Segundo Rabelo (RABELO, 2013, p. 133), quanto maior é o índice de dificuldade mais fácil é o item. Na vertente pedagógica, quanto mais próximo de 1 for o valor de dificuldade, maior será o domínio das competências e habilidades verificadas no item.

Pode-se utilizar a seguinte sugestão para interpretação (CONDé, 2001):

- item fácil: $D>0,70$;

- item de dificuldade média: $0,30<D \leq 0,70$;

- item difícil: $D \leq 0,30$.

De forma geral, "para fins de avaliação de larga escala, os testes devem ser compostos de itens que alcancem todo o continuum da escala, ou seja, devem ter uma amplitude que inclua itens fáceis, medianos e difíceis" (RODRIGUES, 2006, p. 50).

Outro parâmetro importante é a discriminação dos itens $I_{D}$, que se refere ao poder que um item possui para distinguir sujeitos com magnitudes de traços diferentes, do qual 
o item constitui a representação comportamental, segundo Pasquali (1997). Quanto mais próximas forem as magnitudes do traço que o item puder diferenciar, mais discriminativo ele será. Estatisticamente, esse conceito, na TCT, representa a correlação dos escores dos sujeitos no item com seus escores no teste total.

Para estabelecer este conceito, de acordo com Rabelo (2013), inicialmente deve-se dividir a mostra pesquisada em três grupos:

1. grupo superior: os $27 \%$ de maior desempenho;

2. grupo inferior: os $27 \%$ de menor desempenho;

3. grupo intermediário: os $46 \%$ restantes.

O esperado em um bom teste é que no grupo superior haja uma proporção de acertos maior que no grupo intermediário, que, por sua vez, apresente uma proporção maior de acertos que o grupo inferior, em cada item.

É recomendável que $P_{I N F}<P_{I N T}<P_{S U P}$, em que:

- $P_{S U P}$ é o percentual de acerto no grupo superior;

- $P_{I N T}$ é o percentual de acerto no grupo intermediário;e

- $P_{I N F}$ é o percentual de acerto no grupo inferior.

E quanto maior for a diferença entre $P_{S U P}$ e $P_{I N F}$, maior será o potencial de discriminação do item. Adota-se, então, como discriminação, o valor $I_{D}$, conforme a Equação 3.2.

$$
I_{D}=P_{S U P}-P_{I N F}
$$

Os valores de $I_{D}$ recomendáveis são apresentados na Tabela 5 .

Tabela 5 - Classificação dos itens de acordo com o poder de discriminação na TCT (RABELO, 2013, p. 136), com adaptações.

\begin{tabular}{cl}
\hline Valores & Classificação \\
\hline$I_{D} \geq 0,4$ & Item bom \\
$0,3 \leq I_{D}<0,4$ & Item bom, mas sujeito a aprimoramento \\
$0,2 \leq I_{D}<0,3$ & Item marginal, sujeito a reelaboração \\
$I_{D}<0,2$ & Item deficiente, que deve ser rejeitado \\
\hline
\end{tabular}

Há outras medidas da TCT semelhantes ao parâmetro de discriminação. "A principal delas é coeficiente de correlação ponto-bisserial, que varia no intervalo de -1 a 1. 
Valores próximos do zero ou negativos indicam que indivíduos com maior nota no teste como um todo estão errando o item, o que não é aceitável" (RABELO, 2013, p. 139).

O Saeb utiliza a correlação bisserial $c_{b}$. Esta é uma medida de associação entre o desempenho no item e o desempenho no teste. Sua fórmula é dada na Equação 3.3,

$$
c_{b}=\left(\frac{M_{P}-M}{\sigma}\right)\left(\frac{p}{h(p)}\right)
$$

onde $M_{p}$ é a média no teste dos sujeitos que acertam o item, $M$ é a média total do teste, $\sigma$ é o desvio-padrão do teste, $p$ é a proporção de sujeitos que acertam o item e $h(p)$ é a ordenada da curva normal no ponto de divisão dos segmentos que contêm as proporções $p$ dos casos.

Os coeficientes bisseriais $r_{b}$ podem também ser determinados para cada alternativa do item, substituindo-se em $c_{b}$ o valor de $p$ pela proporção de marcações para cada opção do item, fazendo-se uma adaptação no coeficiente ponto-bisserial. Os itens com correlações inferiores a 0,3 são considerados de baixa discriminação, segundo Rabelo.

\begin{abstract}
Por meio da TCT, os índices $p$ e $r$ orientam a tarefa de desenvolvimento do teste definitivo. $\mathrm{O} r_{b}$ calculado por alternativa de itens de múltipla escolha fornece informações preciosas, pois permite indicar um possível distrator (alternativa incorreta) atrativo para os estudantes que se desempenharam bem no teste, o que não é esperado de um item discriminativo. Esses itens podem ser descartados ou mesmo sofrerem algum ajuste pontual, com base nas informações estatísticas, de forma a serem aproveitados no teste final (CONDé, 2008, p. 33).
\end{abstract}

\title{
3.3 Análise Gráfica dos Itens
}

Segundo Rodrigues (2006), esta abordagem técnica foi desenvolvida por T. A. van Batenburg e J. A.Laros e é embasada no pressuposto de que os elabores de itens devem dominar os conceitos da ciência avaliada e seus objetivos. Estes precisam de habilidades específicas para construir um bom item de múltipla escolha.

Para que um item de múltipla escolha seja considerado bom é necessário que este tenha indiscutivelmente um única resposta correta. As alternativas devem ser carregadas de intenção na sua construção e claras no que se propõe. É importante não somente avaliar o conteúdo, mas também a dimensão de compreensão.

Os dois pressupostos válidos para essa análise são:

(a) um aluno que dá uma resposta certa em um item de múltipla escolha possui habilidades que o aluno que dá a resposta errada não alcançou ainda; e

(b) um aluno que tem mais itens certos possui uma gama de conhecimentos maiores que um aluno que acertou menos. 
Isso implica que aqueles que acertam todos os itens (o escore máximo) têm probabilidade 1 de terem marcado a alternativa correta; e aqueles que têm todos os itens errados, têm probabilidade 0 de terem marcado a alternativa correta. Acredita-se, também, que as alternativas falsas decresçam com o aumento do escore total. Até um certo escore, podese esperar que as alternativas certas e as falsas fiquem nos valores da chance de acerto ao acaso (0,25, neste caso). Depois deste escore total específico, a proporção de marcação da alternativa correta aumenta, e a proporção de marcação das alternativas falsas decresce (RODRIGUES, 2006, p. 52).

A Análise Gráfica dos Itens (AGI) dispõe de recursos visuais, em que é apresentada a relação entre o escore total e as porcentagens de respostas às alternativas verdadeiras e falsas dos itens. Essa análise permitiu identificar: bons itens; itens extremamente difíceis; itens que apresentam uma ou mais alternativas falsas e mantêm um aumento da porcentagem de respostas com o aumento do escore total (problema de discriminação); e itens cujas alternativas verdadeiras apresentam um decréscimo na porcentagem de respostas em relação ao aumento do escore total (itens ruins). O principal pressuposto dessa análise, segundo Van Batenburg e Laros (RODRIGUES, 2006, p. 68), é: "a proporção da alternativa correta deve aumentar com um aumento do escore total, e a proporção de alternativas falsas deve decrescer com um aumento do escore total".

Se a proporção de respostas para a alternativa correta aumenta rapidamente com o escore total, o item terá um alto poder discriminativo; caso contrário, será baixo.

Na Figuras 1 e 2 são apresentados exemplos de gráficos para a análise de itens.
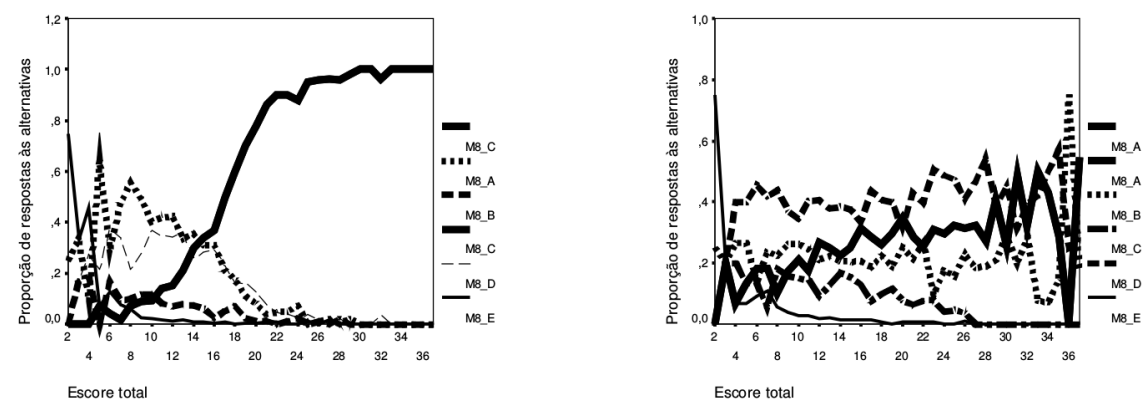

Figura 1 - AGI de item bom e de item ruim, respectivamente (RODRIGUES, 2006, p. $52)$

Tendo por base o escore total, esta análise demonstra uma tendência dos alunos ao responderem o item. Segundo Rodrigues, quando a análise revela uma dispersão nas respostas às alternativas, não significa que um item tem um problema de elaboração, mas pode indicar uma falta coletiva de habilidades diante a objetivo de aprendizagem verificado. "Assim, é importante que, em conjunto com a AGI, seja realizada uma análise pedagógica desses itens. Essas análises poderão dar indicativos do processo mental utili- 

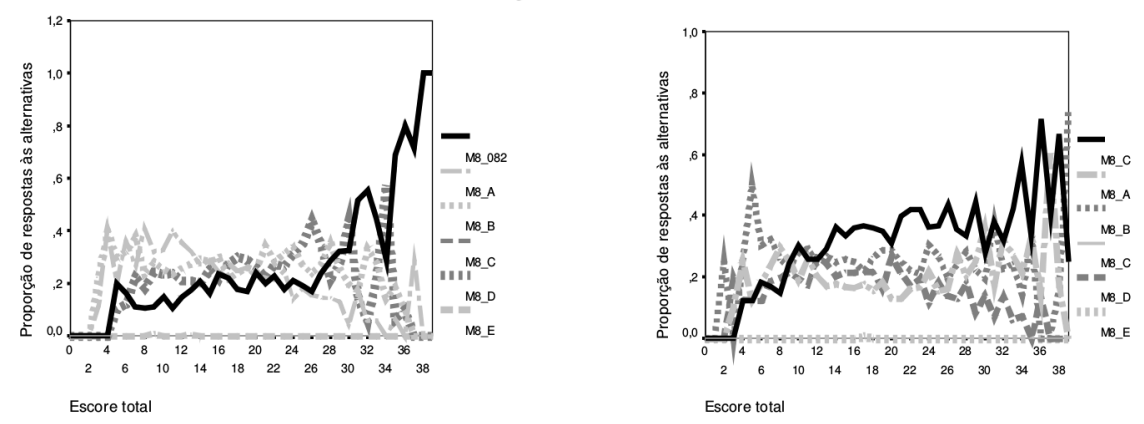

Figura 2 - AGI de item com discriminação ruim e de item difícil, respectivamente (RODRIGUES, 2006, p. 52)

zado para a solução da questão, associando-se o escore total e as respostas dos distratores" (RODRIGUES, 2006, p. 69).

A Teoria Clássica dos Testes apresenta algumas limitações como modelo estatístico: não permite comparar indivíduos que tenham respondido a testes distintos e não permite fazer o acompanhamento de um mesmo sujeito durante as várias etapas do processo de construção do conhecimento. Isso decorre do fato de que, na TCT, os resultados obtidos dependem do conjunto de itens selecionados para a construção da referida prova, tornando o resultado encontrado um caso particular.

No entanto, ela pode respaldar, de acordo com o instrumento escolhido e da amostra, inferências com relação ao estudo dos erros cometidos pelos estudantes que estão sendo investigados.

\subsection{Ambiente construtivista}

Quando se aborda o ensino de Matemática por situações-problema, torna-se primordial que se faça uso de situações mobilizadoras de competências durante a realização de testes e provas. Além de ter um traço desafiador, as questões ou itens da prova devem trazer características que contribuam para uma avaliação formativa. Devem carregar em si informações que contribuam para a clareza e o entendimento de situações fora do contexto escolar.

O estudante, ao se deparar com o teste, deve ter conhecimento técnico do conteúdo estudado e o professor deve fornecer um instrumento que seja conciso com seus objetivos de aprendizagem e que não contribua para o acerto ao acaso. Ao final do teste deve haver uma relação mais próxima possível da realidade do grupo escolar. O aluno que sabe aquilo que é avaliado no item deveria acertá-lo.

Como elaborar questões que permitam avaliar o desenvolvimento de certa habilidade, necessária para o desenvolvimento de uma competência específica, por meio dos 
conhecimentos estudados em sala de aula? Há muitas dúvidas não somente em relação a "como" avaliar mas também a o "que" avaliar.

Para responder o que se deve avaliar é necessário que o docente tenha clareza dos objetivos de aprendizagem que se deseja alcançar naquele momento específico, e, para contribuir de forma mais efetiva com a intenção ao avaliar, pode-se elaborar uma matriz de referência, como as que são utilizadas nos grandes certames: ENEM, Saeb, Prova Brasil. Assim, o docente conseguirá focar na intencionalidade do instrumento avaliativo.

A partir dos PCN e das Diretrizes Curriculares Nacionais (DCN) para o ensino médio houve debates que levaram a um modelo de criação de itens para os mais diversos instrumentos de avaliação, e a prova escrita foi a que mais ganhou com essa nova abordagem. Essa abordagem lança mão da contextualização e da interdisciplinaridade para a elaboração de questões ou itens.

Os itens convencionais, diretos e marcados apenas pela verificação de aprendizagem de conteúdos, foram perdendo seu espaço para os itens contextualizados. De acordo com Rabelo, os itens convencionais refletem "uma cobrança estritamente voltada à capacidade de se utilizar o conhecimento aprendido na reprodução de procedimentos rotineiros ou na identificação ou reconhecimento de dados e informações" (RABELO, 2013).

Mas não se pode confundir contextualização com textualização: esta última é marcada apenas pela apresentação de textos conjuntamente com a questão, que em nada contribuem para a sua realização. Apesar de deixarem o teste mais interessante, trazendo curiosidades e até mesmo gerando descontração durante a realização da prova, estes textos não desafiam nem mobilizam habilidades necessárias a resolução da situação apresentada no comando do item. A Figura 3 ilustra um item convencional.

12. A figura mostra um polígono regular de dez lados com centro O. Qual é a medida do ângulo a?
A) $15^{\circ}$
B) $18^{\circ}$
C) $20^{\circ}$
D) $30^{\circ}$
E) $36^{\circ}$

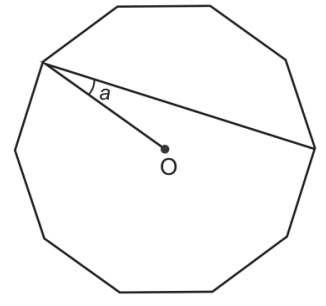

Figura 3 - Exemplo de item convencional

A contextualização vai na contramão da textualização, pois caracteriza-se pela consulta ao texto apresentado para melhor entendimento da situação-problema, pela mobilização de habilidades necessárias para resolvê-la e ainda pela oferta de dados primordiais para o processo de resolução.

A contextualização, além de cumprir o papel de possibilitar a descrição de uma 
situação-problema a ser resolvida, de modo a propiciar que a competência ou a habilidade a ser avaliada se expresse, tem o papel de motivar o estudante para resolver a atividade proposta, além de favorecer o processo de criação de itens inéditos e de testes interdisciplinares (RABELO, 2013, p. 179).

O contexto escolhido também determina a facilidade em se resolver o item. Para Rabelo, se o contexto for próximo ao cotidiano dos alunos, a contextualização se torna mais motivadora e de mais fácil entendimento para estes, mas os contextos "abstratos ou técnico-científicos, que demandam raciocínios mentais elaborados, costumam apresentar níveis de complexidade de julgamentos mais sofisticados" (RABELO, 2013, p. 179).

O uso de situações-problema contextualizadas denota um ambiente construtivista de aprendizagem, e o ineditismo dos itens apresentados também fortalece esse conceito. $\mathrm{O}$ estudante, ao enfrentar situações propostas em itens inéditos, mobiliza conhecimentos e habilidades e os aplica para confirmar competências almejadas nos objetivos. O ineditismo não é aplicado aos itens apenas para estabelecer o equilíbrio entre os concorrentes, mas também para que o estudante tenha a possibilidade de evidenciar o desenvolvimento de competências e poder manifestá-las.

Depresbiteris e Tavares, apud Rabelo, sugerem que

os ambientes construtivistas são fundamentais para o ensino e a aprendizagem, principalmente quando fornecem situações-problema desencadeadoras de um processo de pensar fomentador da dúvida, do levantamento, do comprovação de hipóteses, do pensamento inferencial, do pensamento divergente, entre outros(RABELO, 2013). 


\section{Engenharia de Itens}

é preciso ter em mente que o item é a base a partir da qual serão construídos os indicadores de qualidade que fornecerão insumos para formular ações educacionais, promover a melhoria dos processos de ensinoaprendizagem e subsidiar tomadas de decisão dos gestores em todos os níveis Se os itens não forem cuidadosamente construídos, os indicadores não serão válidos nem fidedignos e toda a análise feita a partir desses índices ficará comprometida (RABELO, 2013, p. 216).

\subsection{Conceitos básicos de elaboração de itens}

Com base nos cuidados em construir uma avaliação que revele níveis de aprendizado, é necessário que se apresente os conceitos iniciais. Como este estudo é embasado na Teoria de Resposta ao Item, o termo "questão" de prova não é utilizado, mas, sim, o termo item de prova. Esta é apenas uma questão de terminologia, pois os itens são as questões que o professores apresentam em suas listas de exercícios ou testes. É necessário fazer essa diferenciação para que não se confunda com itens de julgamento, aqueles onde se julgam a veracidade ou não da informação.

De acordo com Rabelo (2013), um item de prova

é uma situação criada para que o indivíduo dê uma resposta ou um conjunto de respostas a um estímulo apresentado, constituindo-se em uma amostra de desempenho em relação a um objeto específico previsto em uma matriz de referência,

e uma prova "é uma situação na qual se solicita a alguém que demonstre certo aspecto de seus conhecimentos ou de suas capacidades, com o objetivo de avaliar determinadas características previamente estabelecidas".

Uma avaliação escrita pode ser construída a partir de um item ou vários. É comum em um teste dissertativo, por exemplo, o elaborador apresentar um item apenas a ser respondido. Mas podem ser empregados vários itens em uma prova e estes podem apresentar vários formatos. Na próxima seção são apresentados alguns exemplos que se baseiam na forma com que o avaliado expressa sua resposta.

\subsection{Formatos comuns de itens}

Múltipla escolha: são itens nos quais o candidato ou estudante escolhe uma única resposta entre várias apresentadas, denominada chave de resposta ou gabarito, a qual 
precisa ser inequivocamente certa, enquanto as demais devem ser incorretas e plausíveis. É o modelo adotado na primeira fase da OBMEP.

Certo ou Errado: são marcados pelo julgamento do respondente. Devem ser bem claros e sua resposta é binária, respeitando o Principio do Terceiro Excluído, não havendo uma outra opção além de certo ou errado. Na construção de testes com estes itens, deve-se tomar cuidado para que não haja padrão no gabarito, pois se o estudante verifica que há uma padronização, ele obterá um resultado que não refletirá o objetivo da avaliação.

Resposta fechada: é caracterizado por ter uma resposta correta que deve ser elaborada pelo aluno, na qual ele pode completar uma ideia com uma única resposta possível. Pode ser utilizado um padrão de gabarito que possibilite essa resposta, mas não são apresentadas as opções de resposta. Como exemplo, há itens que exigem um cálculo e a resposta é colocada em um gabarito que possibilita a marcação utilizando o sistema posicional.

Dissertativo ou redação: utilizando textos, figuras ou tabelas como motivação. O elaborador leva o estudante a discorrer sobre determinado tema de forma textual. $\mathrm{O}$ elaborador pode propor tópicos a serem apresentados ou não e o avaliador, também apoiado em uma matriz de referência, busca evidências do domínio do assunto tratado, além de avaliar o uso formal da língua e a formalização das ideias. A Figura 4 traz um exemplo de item discursivo.

\section{QUESTÃO DISCURSIVA 2}

Três jovens de 19 anos de idade, moradores de rua, foram presos em flagrante, nesta quarta-feira, por terem

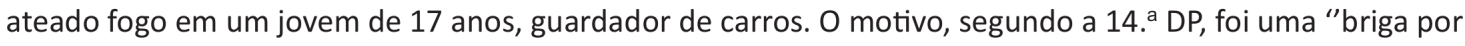
ponto". Um motorista deu "um trocado" ao menor, o que irritou os três moradores de rua, que também guardavam carros no local. O menor foi levado ao Hospital das Clínicas (HC) por PMs que passavam pelo local. Segundo o HC, ele teve queimaduras leves no ombro esquerdo, foi medicado e, em seguida, liberado. Os indiciados podem pegar de 12 a 30 anos de prisão, se ficar comprovado que a intenção era matar o menor. Caso contrário, conforme a $14 .^{a}$ DP, os três poderão pegar de um a três anos de cadeia.

Disponível em:<http://www1.folha.uol.com.br>. Acesso em: 28 jul. 2013 (adaptado).

A partir da situação narrada, elabore um texto dissertativo sobre violência urbana, apresentando:

a) análise de duas causas do tipo de violência descrita no texto; (valor: 7,0 pontos)

b) dois fatores que contribuiriam para se evitar o fato descrito na notícia. (valor: 3,0 pontos)

Figura 4 - Exemplo de item discursivo

Resposta curta aberta ou de resposta construída: estes itens se diferenciam do anterior, por possuírem mais de uma resposta possível, mas ambas corretas. Estes itens são avaliados por uma banca de corretores, que verificam se as respostas estão de acordo com a proposta do elaborador, mesmo que elas sigam passos distintos de 
resolução. É montada uma matriz de correção apresentando as respostas possíveis e requisitos a serem cumpridos. A Figura 5 exemplifica um item deste tipo.

1. Pedro constrói uma sequência de pilhas com cubinhos de tamanhos iguais. Ele começa com um único cubinho. As pilhas são construídas sempre de forma triangular, a partir da anterior, aumentando-se dois cubinhos em cada camada e colocando-se um cubinho no topo. Na figura, estão representadas as três primeiras pilhas da sequência. Observe que na primeira camada da terceira pilha há cinco cubinhos.

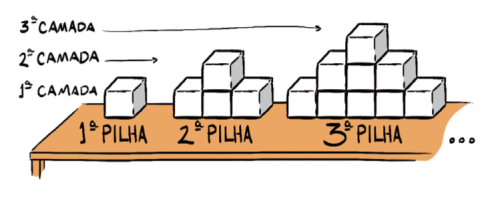

a) Quantos cubinhos deverá ter a primeira camada da quinta pilha?

b) Quantos cubinhos deverá ter a primeira camada da $2014^{\mathrm{a}}$ pilha?

c) Pedro observou que podia transformar qualquer pilha triangular em uma pilha quadrada, reorganizando os cubinhos dessa pilha. Observe na figura como ele fez isso com a quarta pilha.
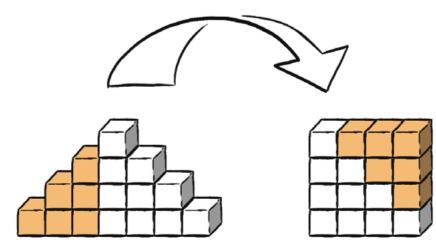

Ele usou essa ideia para calcular quantos cubinhos são necessários para construir uma pilha triangular com 99 cubinhos em sua primeira camada. Que resultado ele obteve?

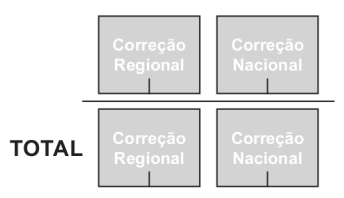

Figura 5 - Exemplo de item de resposta curta aberta - $2^{\text {a }}$ Fase da OBMEP

Em todos os formatos, o candidato/estudante deve ser informado previamente das regras de apresentação dos itens e o que se espera dele diante de cada um. É importante a verificação do tempo necessário para responder cada item. Se o itens forem dos tipos: múltipla escolha, certo ou errado ou resposta fechada, o professor deve considerar que 
um aluno com proficiência mediana leva em torno de 3 a 4 minutos para respondê-los, enquanto os outros tipos podem ser mais demorados. Então, ao construir a matriz de referência para os corretores, o elaborador pode redimensionar a questão para o tempo disponível para sua resolução.

É importante também para uma avaliação formativa que se saiba o que vem a ser a mobilização de habilidades para se articular competências, pois é um tema tratado pela abordagem construtivista da aprendizagem e também pela Engenharia de Itens. A contextualização e o ineditismo de itens se apoiam nesses conceitos.

\title{
4.3 Habilidade e Competência
}

Como o auto-monitoramento é um dos objetivos almejados pela avaliação formativa, quando os conceitos de competências e habilidades foram introduzidos, era enfatizado que o aluno aprendesse a aprender. Assim, no princípio, esses conceitos transmitiam a ideia de que o conteúdo apresentado pelo professor fosse deixado de lado para que o aluno fosse motivado a construir seu próprio aprendizado.

É um erro pensar que o professor não pode ensinar conceitos: ele deve sim apresentálos e discuti-los com seus alunos, incorporando a isso atividades que incentivem a mobilização de recursos (habilidades, conhecimentos, atitudes, processos mentais, entre outros) para o saber fazer. Rabelo apresenta a distinção entre habilidades e competências, apresentada no Enem, e acrescenta que "o estudo intenso de conteúdos" se faz necessário para articulação entre esses conceitos.

\begin{abstract}
Competências são modalidades estruturais da inteligência, isto é, ações e operações que utilizamos para estabelecer relações com e entre objetos, situações, fenômenos e pessoas que desejamos conhecer, enquanto habilidade são especificações das competências estruturais em contextos específicos, decorrem da competências adquiridas e referem-se ao plano imediato do saber fazer. Por meio das ações e operações, as habilidades aperfeiçoam-se e articulam-se, possibilitando nova reorganização das competências (RABELO, 2013, p. 187).
\end{abstract}

Perrenoud (2002 apud RABELO, 2013, p. 188) define que

competência é a capacidade do sujeito de selecionar, organizar, mobilizar e utilizar, intencionalmente, recursos (conhecimentos, saberes, habilidades, esquemas mentais, afetos, crenças, princípios, posturas, comportamentos e outros processos psicológicos ou comportamentais) e em ação para o enfrentamento de uma situação problema especifica, não apenas na dimensão técnico-especializada, mas também na dimensão sociopolítica, comunicacional e de inter-relações pessoais.

Assim, durante a construção de um item, deve-se levar em consideração a mobilização e articulação entre os diversos recursos para que se propicie uma avaliação significativa, 
de forma que o estudante verifique o quão distante ele está do que o professor espera dele ao realizar as avaliações escritas. É importante frisar que o docente pode se apoiar na sua matriz de referência de competências para elaboração de cada item e até mesmo para a elaboração dos distratores de cada item, conceito apresentado na Seção 4.7 .

\subsection{Estrutura básica de um item de múltipla escolha}

A estrutura dos itens de múltipla escolha é dividida em texto-base, enunciado ou comando e as alternativas, onde estas partes se articulam com coerência e coesão, para que as informações apresentadas levem o aluno a mobilizar os diversos recursos necessários para responder o item.

A Figura 6 apresenta visualmente a estrutura básica de um item.

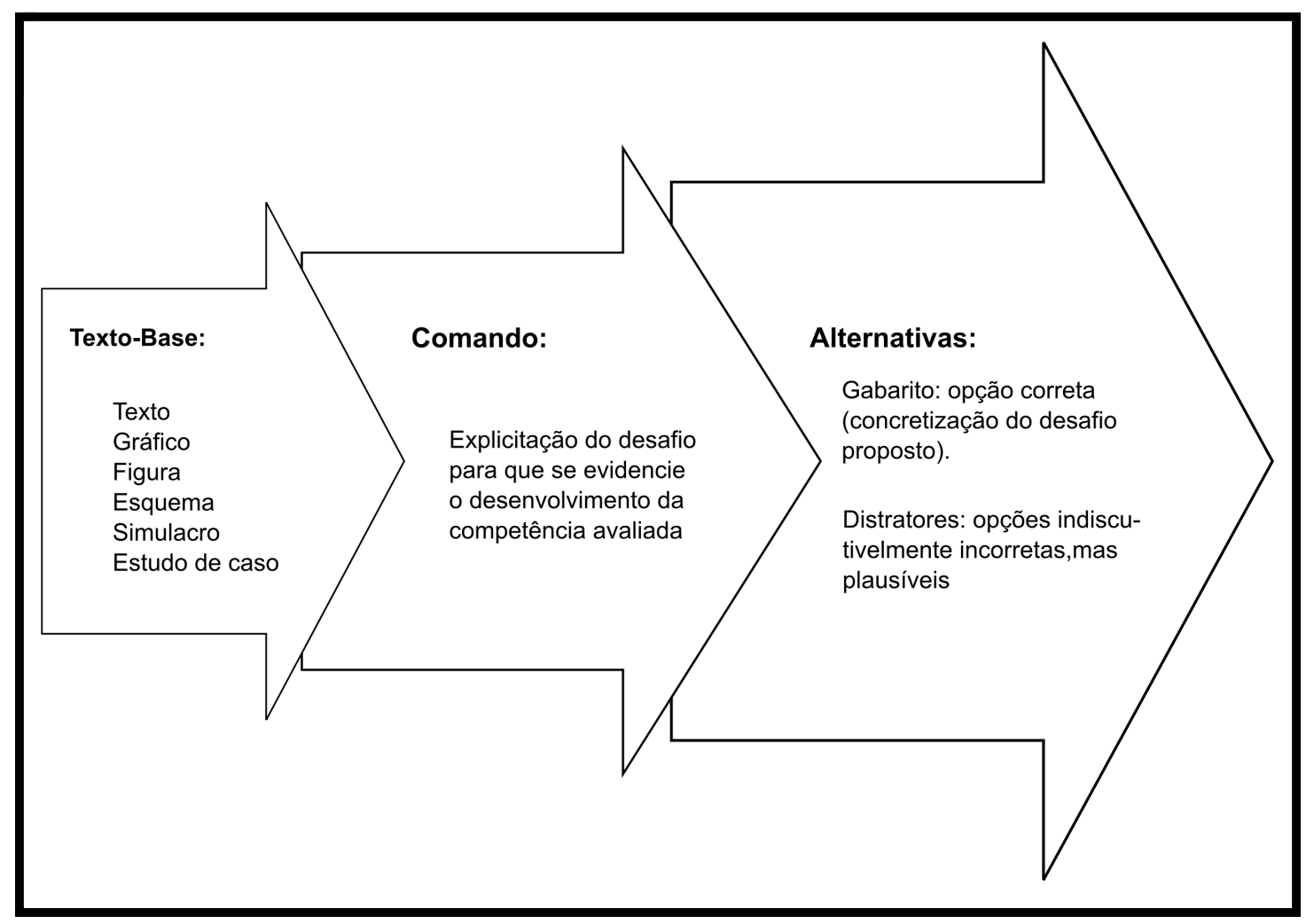

Figura 6 - Estrutura Básica do Item (adaptado de (RABELO, 2013))

\subsection{O Texto-Base}

Segundo Rabelo (2013, pg. 190), no processo de elaboração, primeiro deve-se escrever o texto-base, que também pode ser buscado em fontes externas, depois o comando e, por fim, as alternativas. Antes de serem formulados, os itens devem ser enquadrados na 
matriz de referência, contemplando a perspectiva de avaliação de uma habilidade e(ou) competência com mais ênfase.

O texto-base deve servir de contextualização, ou seja, as informações apresentadas devem ser relevantes para o respondente. Um bom teste para a relevância do texto é verificar se, ao ser excluído, o aluno tem informações suficientes para encontrar a resposta correta.

Os textos-base devem ser curtos, integrais e adequados à linguagem e ao nível dos respondentes. Quando utilizados textos que não são de autoria do elaborador, é importante buscar em fontes com reconhecimento científico, não sendo conveniente utilizar fontes duvidosas ou incompletas em seus conceitos. O texto original pode ser alterado, mas qualquer mudança no texto deve ser referenciada (RABELO, 2013).

Ainda sobre o texto-base, deve haver clareza nos fatos apresentados tanto no uso correto da Língua Portuguesa, quanto nos conceitos científicos utilizados. Este deve orientar o respondente a acessar os seus conhecimento prévios e construir novas perspectivas quanto aos conceitos apresentados. Assim, quando houver controvérsias de base cientificas, será preciso citar no texto-base a interpretação que deverá ser utilizada.

É bom conceituar e exemplificar no texto-base (dependendo da intencionalidade do item, é claro), pois uso de exemplos e conceituação tendem a tornar o item mais fácil. Se feito desta forma, deve-se observar que o conceito apresentado deve estar correto cientificamente e não levar o respondente a aplicá-lo apenas na resolução do item em questão.

A Figura 7 apresenta um item com exemplificação no texto-base.

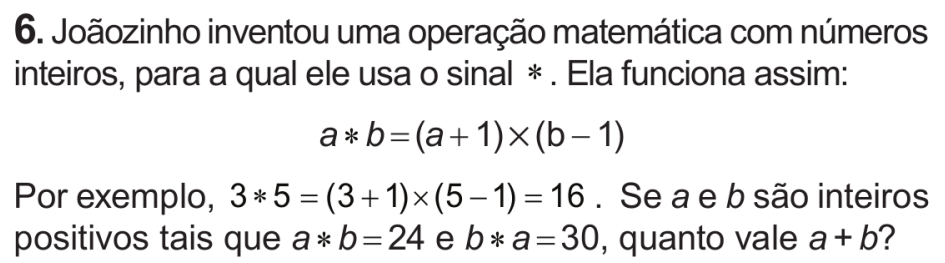
A) 11
B) 12
C) 15
D) 16
E) 18

Figura 7 - Item com exemplificação no texto-base

É bom que não se criem nomes fictícios ou jocosos, ou nomes que se refiram a pessoas públicas. Para todos os modelos citados, observar o teor político, utilização de marcas de produtos, nomes e imagens, pois podem ser utilizados para influenciar os respondentes. 


\subsection{O Comando}

O comando pode ser dado como uma afirmação incompleta, a ser continuada por uma das opções, onde o estudante deve encontrar, entre as opções oferecidas, aquela que se ajusta corretamente ao comando que deve ser completado. São chamados de itens de múltipla escolha de complementação simples. A Figura 8 exemplifica um item deste tipo.

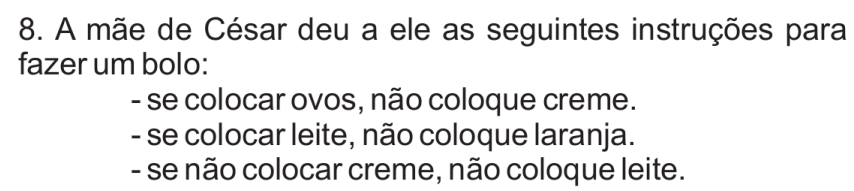

Seguindo essas instruções, César pode fazer um bolo com
A) ovos e leite, mas sem creme.
B) creme, laranja e leite, mas sem ovos.
C) ovos e creme, mas sem laranja.
D) ovos e laranja, mas sem leite e sem creme.
E) leite e laranja, mas sem creme.

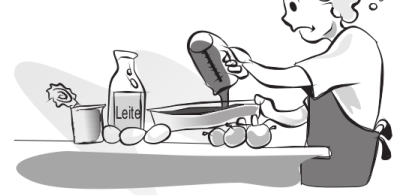

Figura 8 - Exemplo de item de múltipla escolha de complementação simples.

Para estes deve-se atentar que o enunciado é redigido de forma que as alternativas o complemente, assim todas as alternativas são trechos que completam a frase interrompida no enunciado. Desse modo, as alternativas devem ser iniciadas com letras minúsculas e terminam com ponto final, e devem obedecer a um paralelismo sintático entre si.

O comando também pode ser formulado por uma pergunta direta, em que se apresenta um único e completo problema e cada opção de resposta é uma possível solução. São chamados de itens de múltipla escolha de resposta única, e a diferença em relação ao anterior diz respeito à redação das alternativas: estas serão redigidas de forma a responder a pergunta do enunciado, de modo que iniciarão por letra maiúscula. A Figura 9 traz um item de pergunta direta.

7. Um retângulo de papelão com $45 \mathrm{~cm}$ de altura é cortado em dois pedaços, como na figura. Com esses dois pedaços é possível montar um quadrado de lado maior que $45 \mathrm{~cm}$. Qual é o comprimento da base do retângulo?
A) 65
B) 70
C) 75
D) 80
E) 85

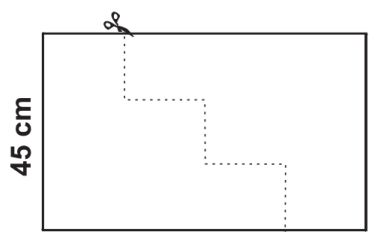

Figura 9 - Exemplo de item de pergunta direta. 
Para os itens de múltipla escolha de interpretação, estes podem ser com enunciado incompleto ou com pergunta, e a escolha deve priorizar a clareza do enunciado. Estes itens são formulados a partir de uma situação-estímulo que compõe o enunciado e o respondente organiza as ideias para solucionar o problema proposto. Este é o modelo utilizado no ENEM. A situação-estímulo pode ser utilizada para mais de um item, desde que estes sejam independentes. Em geral, é formado um banco de textos base para a situaçãoestímulo, que são incorporados ao enunciado e as ideias que aparecem nas alternativas. Deve-se atentar para que não existam itens excludentes. A Figura 10 é um exemplo de item de múltipla escolha de interpretação.

\section{QUESTÃO 172}

O Ministério da Saúde e as unidades federadas promovem frequentemente campanhas nacionais e locais de incentivo à doação voluntária de sangue, em regiőes com menor número de doadores por habitante, com o intuito de manter a regularidade de estoques nos serviços hemoterápicos. Em 2010, foram recolhidos dados sobre o número de doadores e o número de habitantes de cada região conforme o quadro seguinte.

\begin{tabular}{|c|r|c|c|}
\hline \multicolumn{4}{|c|}{ Taxa de doação de sangue, por região, em 2010 } \\
\hline Região & Doadores & $\begin{array}{c}\text { Número de } \\
\text { habitantes }\end{array}$ & $\begin{array}{c}\text { Doadores/ } \\
\text { habitantes }\end{array}$ \\
\hline Nordeste & 820959 & 53081950 & $1,5 \%$ \\
\hline Norte & 232079 & 15864454 & $1,5 \%$ \\
\hline Sudeste & 1521766 & 80364410 & $1,9 \%$ \\
\hline Centro-Oeste & 362334 & 14058094 & $2,6 \%$ \\
\hline Sul & 690391 & 27386891 & $2,5 \%$ \\
\hline Total & 3627529 & 190755799 & $1,9 \%$ \\
\hline
\end{tabular}

Os resultados obtidos permitiram que estados, municípios e o governo federal estabelecessem as regiőes prioritárias do país para a intensificação das campanhas de doação de sangue.

A campanha deveria ser intensificada nas regiões em que o percentual de doadores por habitantes fosse menor ou igual ao do país.

Disponivel em: http://bvsms.saude.gov.br. Acesso em: 2 ago. 2013 (adaptado).

As regiōes brasileiras onde foram intensificadas as campanhas na época são

A Norte, Centro-Oeste e Sul.

B) Norte, Nordeste e Sudeste.

C Nordeste, Norte e Sul.

(D) Nordeste, Sudeste e Sul.

G Centro-Oeste, Sul e Sudeste.

Figura 10 - Exemplo de item de múltipla escolha de interpretação.

Nos itens de interpretação, evite utilizar as expressões "assinale a opção correta" 
ou "é correto afirma que", pois levam a cinco problema diferentes a serem julgados, não deixam claro o desafio proposto, e podem extrapolar a habilidade a ser verificada.

É preciso também salientar que tudo que está escrito em cada afirmação é passível de julgamento, salvo se explicitado como hipótese. Muitas vezes, o elaborador relata na afirmação uma situação, mas não insere afirmações do tipo "Suponha que" ou "considere que", antes da descrição do problema. Trata-se de uma sutileza, mas que é fundamental para a clareza do item e melhor compreensão por parte do estudante.

\subsection{As alternativas}

Cabe enfatizar que as informações para resolução não devem ser encadeadas nas alternativas do item, pois as informações necessárias à resolução devem estar no texto-base ou no comando. E ainda é importante salientar que não deve ser colocada a alternativa correta com extensão ou formato diferente das demais para não haver atração, por causa da diferenciação. Se as alternativas possuírem tamanhos diferenciados elas devem ser organizadas de forma trapezoidal.

Além disso, se as alternativas forem numéricas, estas devem ser organizadas de forma crescente ou decrescente, e não devem apresentar ponto final quando não houver texto na sua composição e/ou estas não completarem um texto.

Fugir ao uso de expressões do tipo "nenhuma das anteriores" ou "todas as respostas anteriores" e, além destas expressões, alguns termos devem ser evitados, pois sua generalidade já descarta a alternativa analisada. Abaixo segue uma relação de termos a serem evitados:

somente, apenas, nunca, exclusivamente, unicamente, sempre, totalmente, todo, jamais, raramente, exclusivamente, pode ser, tudo, ninguém, nenhum, nada, algum, pode acontecer, pode haver, pouco, as vezes, qualquer, entre outros... (RABELO, 2013, p. 195).

As opções erradas, denominadas distratores, devem ser cuidadosamente construídas e analisadas, fazer parte do contexto do item e ser uma resposta possível para que o aluno que não sabe o conteúdo ou que não desenvolveu a competência que está sendo avaliada. Deve-se construir distratores plausíveis que tenham a aparência de resposta correta, mas que sejam inquestionavelmente incorretas. Se o contrário acontecer, o item possui erros, ou seja, o item não discrimina, e deverá ser reformulado ou até mesmo retirado da avaliação.

O distrator não deve ser um "peguinha", ou seja, atrair a resposta de quem sabe o conteúdo e que por um descuido fez essa escolha: deve ser a resposta possível para um caminho errado de interpretação ou uso de conceitos errôneos. Aqui os distratores se 
apoiam no conceito de discriminação do item, ou seja, alunos com proficiência igual ao superior exigida pelo item devem acertá-lo e alunos com proficiência inferior ao item devem errá-lo. "É desejável que cada distrator esteja vinculado a um nível de desenvolvimento adequado da aprendizagem e ensejar um possível raciocínio que um respondente de baixo desempenho faria para escolhê-lo como resposta"(RABELO, 2013, p. 191).

Um item elaborado com essa critério permitiria que fosse identificado, na fase de análise de desempenho, os erros mais comuns nos diversos níveis de proficiência dos estudantes e, assim, fornecer indícios sobre o processo resolução escolhido pelos respondentes. A partir deste princípio, a prova de primeira fase da OBMEP em estudo será analisada no Capítulo 8.3.

\footnotetext{
Quando planejamos e realizamos uma atividade de avaliação (sejam quais forem sua natureza e características), temos de estar conscientes de que os alunos também estão atribuindo-lhe um sentido, de que esse sentido depende, em grande parte, de como a atividade é apresentada e de como atuamos em seu desenvolvimento e de que, enfim, os resultados de avaliação dependerão tanto dos significados que eles construíram e que sejamos capazes de suscitar, como no sentido que atribuíram às atividades previas de ensino e aprendizagem e à própria atividade de avaliação (RABELO, 2013, p. 196).
}

Com relação ao gabarito final, construa a chave de respostas de tal forma que as combinações não forneçam pistas quanto a opção correta, ou seja, faça o balanceamento da quantidade de vezes que o número de cada afirmação aparece nas alternativas corretas.

\subsection{O Correto Uso da Língua Portuguesa na Avaliação para a Aprendizagem}

No momento de elaboração do item, deve-se atentar ao bom uso da Língua Portuguesa. Na elaboração do texto do item:

- utilizar a ordem direta;

- adequar a simplicidade dos vocábulos;

- atentar à correção da linguagem, clareza, precisão, impessoalidade;

- evitar o uso de adjetivos ou advérbios, pois estes destacam ideias subjetivas; e

- não usar a primeira pessoa do plural, pois não se pode incluir o elaborador no grupo de respondentes.

Para itens de múltipla escolha do tipo resposta múltipla, que consistem de 3 a 5 afirmações relacionadas com o enunciado, que devem ser avaliadas como verdadeiras ou 
falsas, deve-se, especialmente, levar em consideração que os julgamentos das afirmações devem ter o mesmo nível de complexidade. Durante a análise, os números nas alternativas devem aparecer balanceadamente e na ordem crescente e os itens excludentes não devem aparecer na mesma alternativa de resposta. Além disso, para o item de resposta múltipla, em suas alternativas, não se deve combinar informações excludentes. A Figura 11 exemplifica um item deste tipo.

\section{QUESTÃO 22}

Um dos problemas mais importantes estudados pelo cálculo diferencial e integral diz respeito à maximização e minimização de funções. Um desses problemas está relacionado à função cúbica definida por

$$
f(x)=a x^{3}+b x^{2}+c x+d,
$$

em que $a, b, c$ e $d$ são constantes reais, com $a \neq 0$.

Acerca dessa cúbica, avalie as afirmações a seguir.

I. A função $f$ possui apenas um ponto de inflexão, independentemente dos valores de $a, b, c$ e $d$.

II. Se $b^{2}-3 a c>0$, então $f$ possui um ponto de máximo local e um ponto de mínimo local.

III. Se $f$ possui um ponto de máximo local e um ponto de mínimo local, então a média aritmética das abscissas desses dois pontos extremos corresponde à abscissa do ponto de inflexão.

\section{É correto o que se afirma em}
A I, apenas.
B II, apenas.
C I e III, apenas.
D II e III, apenas.
E I, II e III.

Figura 11 - Item de múltipla escolha de resposta múltipla

Após serem elaborados, um olhar externo é fundamental, para que haja uma correção quanto a clareza dos itens e a correspondência com a intenção dos aplicadores, pois itens aparentemente perfeitos podem apresentar nuances que levem os respondentes a tomarem posturas que não correspondam à intenção do elaborador. 
É de grande relevância, também, a pré-testagem do item: o professor, ao aplicar um item em determinado grupo, pode fazer alterações nos próximos testes. Pode-se caracterizar esta atitude como uma ação da avaliação formativa para o professor avaliador/elaborador.

Os tipos de item de asserção-razão, abertos e os dissertativos são itens que requerem processos cognitivos mais elaborados, pois requerem julgamento de casualidade entre fatos.

Quanto aos tipos de itens abertos e os dissertativos, além das diretrizes apresentadas acrescenta-se que para o enunciado/comando deve se incluir todas as informações necessárias para a resolução do item e que serão objeto de avaliação: textos motivadores, informações técnicas especificas, tabelas, figura e fórmulas que sejam necessárias para a resolução da proposta apresentadas. Não é recomendável o emprego de perguntas do tipo "Que", "Quem", "Quando", "Onde", pois, possivelmente, não avaliam a mobilização de habilidades complexas para a construção da resposta.

Se possível subdividir em subitens, objetivando clareza e contribuindo para uma correção mais pontual. O avaliador deve redigir um padrão de resposta desejável se colocando no papel do avaliado, evidenciando partes essenciais que devem ser usadas processo; fazer previsão das diferentes respostas corretas e validas e estabelecer o critério de pontos (quesitos da avaliação) - considerando a indicação do valor atribuído a cada item contemplado.

O formato de um item deverá ser norteado pela intenção da avaliação: se o procedimento de resolução não nos interessa é melhor escolher as questões de múltipla escolha, caso contrário de itens abertos e os dissertativos podem esclarecer para o elaborador os caminhos corretos utilizados e, mais que isso, os obstáculos enfrentados pelos alunos.

Cada instrumento de avaliação deve ser escolhido de acordo com a intencionalidade do elaborador. No que tange à dificuldade dos itens, deve-se adequar os itens de forma que se obtenha $30 \%$ de itens fáceis, $40 \%$ de itens medianos e $30 \%$ de itens difíceis em uma prova de seleção, mas em uma avaliação de aprendizagem sugere-se que sejam $30 \%$ de itens fáceis, $50 \%$ de itens medianos e $20 \%$ de itens difíceis.

Ao finalizar a construção de um item é bom fazer uso de uma série de questionamentos que verificam rapidamente alguns dos pontos apresentados no texto de Engenharia de Itens por Rabelo. Estes se apresentam na Tabela 6. 
Tabela 6 - Questionamentos de verificação de itens (RABELO, 2013, p. 217)

\begin{tabular}{ll}
\hline$\#$ & Questionamento \\
\hline 1 & A redação do contexto é adequada? O item de fato é contextualizado? \\
2 & O tamanho do contexto é adequado ao tempo disponível para resolução? \\
3 & Os dados têm razoabilidade e são todos necessários para a resolução? \\
4 & Qual a competência ou habilidade que se deseja avaliar no item? \\
5 & O enunciado está redigido sem o uso de termos que indicam negação? \\
6 & O enunciado apresenta claramente um único problema a ser solucionado? \\
7 & O enunciado apresenta falha técnica que pode induzir ao erro? \\
8 & As opções/alternativas completam adequadamente o comando? \\
9 & As opções/alternativa apresentam estrutura semelhante? São indepen- \\
& dentes? \\
10 & Há exatamente uma opção inequivocamente correta? \\
11 & Os distratores são plausíveis? \\
12 & Os distratores são claros, sem indução ao erro? \\
13 & O item é isento de erros conceituais? \\
14 & O item é isento de informações preconceituosas e controversas? \\
15 & O item está redigido respeitando a norma padrão da língua portuguesa? \\
\hline
\end{tabular}





\section{Análise de Conteúdo}

Um conjunto de técnicas de análise de comunicação visando a obter, por procedimentos sistemáticos e objetivos de descrição do conteúdo das mensagens, indicadores. A intenção da Análise de Conteúdo é a inferência de conhecimentos relativos às condições de produção (ou, eventualmente, de recepção), inferência esta que recorre a indicadores (quantitativos ou não) (BARDIN, 2011, p. 44).

\subsection{A Análise de Conteúdo}

Como se pode perceber pela definição apresentada, a Análise de Conteúdo oscila entre os dois contrapontos que envolvem a investigação científica: o rigor da objetividade e a fecundidade da subjetividade. Esta abordagem gera elaboração de indicadores quantitativos e(ou) qualitativos que devem levar o pesquisador a uma segunda leitura da comunicação, baseando-se na dedução, na inferência. Visa revelar o que está escondido, latente, ou subentendido na mensagem, mas com a presença de processos técnicos de validação.

As análises quantitativas preocupam-se com a frequência com que surgem determinados elementos nos instrumentos de pesquisa, preocupando-se com mensuração dos dados apresentados. Por outro lado, os enfoques qualitativos voltam sua atenção para a presença ou ausência de uma característica, ou conjunto de características, nas mensagens analisadas, na busca de ultrapassar o alcance meramente descritivo das técnicas quantitativas para atingir interpretações mais profundas com base na inferência (BARDIN, 2011).

A Análise de Conteúdo visa, portanto, "ultrapassar o nível do senso comum e do subjetivismo na interpretação e alcançar uma vigilância crítica em relação à comunicação de documentos, textos literários, biografias, entrevistas ou observação" (MINAYO, 2000).

Em relação à Análise de Conteúdo, de acordo com Cury (2003, p. 7), entre "as obras que apresentam elementos para entender esse método, a de Bardin foi sem dúvida a que melhor o configurou em detalhes, especificando os conceitos, os princípios e a técnica propriamente dita".

Bardin (2011) caracteriza a Análise de Conteúdo como sendo empírica e, por esse motivo, não pode ser desenvolvida com base em um modelo exato. Contudo, para sua operacionalização, devem ser seguidas algumas regras de base, por meio das quais se parte de uma leitura flutuante para atingir um nível mais aprofundado - a inferência apoiada em dados organizados. 
Para Bardin (2011), não se trata de atravessar os significantes para atingir significados, como se faz na leitura normal, mas de, por meio dos significantes e dos significados (manipulados), buscar-se diferentes significados de natureza psicológica, sociológica, política, histórica, educacional, entre outros. Muito empregada nas Ciências Sociais, a Análise de Conteúdo vislumbra sua aplicação na Análise de Erros, ou seja, contempla os estudos da Educação Matemática, fundamentando suas produções.

O processo de explicitação, sistematização e expressão do conteúdo de mensagens, promovido pela Análise de Conteúdo, é organizado em três etapas, realizadas em conformidade com três momentos de estudo diferentes. De acordo com Bardin (2011) e Minayo (2000), essas etapas compreendem a pré-análise, a exploração do material e o tratamento dos resultados obtidos e interpretação.

\subsubsection{Pré-análise}

Fase de organização e sistematização das ideias, em que ocorre a escolha dos documentos a serem analisados, a retomada das hipóteses e dos objetivos iniciais da pesquisa em relação ao material coletado, e a elaboração de indicadores que orientarão a interpretação final.

A pré-análise pode ser decomposta em quatro etapas:

1. leitura flutuante, na qual deve haver um contato com o material de análise, deixandose invadir por impressões e orientações;

2. constituição do Corpus, que envolve a organização do material de forma a responder a critérios de exaustividade (não deixar de fora qualquer elemento), representatividade da amostra, homogeneidade entre os objetos retidos e pertinência dos documentos utilizados;

3. formulação de hipóteses e objetivos, ou de pressupostos iniciais flexíveis que permitam a emergência de hipóteses a partir de procedimentos exploratórios;

4. referenciação dos índices e elaboração dos indicadores a serem adotados na análise, e preparação do material .

\subsubsection{A Exploração do Material}

Trata-se da fase em que os dados brutos do material são codificados para se alcançar o núcleo de compreensão do texto. A codificação envolve procedimentos de recorte, contagem, classificação, desconto ou enumeração em função de regras previamente formuladas. 
Segundo Triviños (1987 apud CURY, 2003), esta etapa pode ser chamada de descrição analítica, envolve um estudo aprofundado do corpus, com procedimentos de unitarização e categorização.

A unitarização é o processo que consiste em reler o material para definir as unidades de análise, que podem ser "palavras, frases, termos ou mesmo documentos em sua forma integral" (MORAES, 1999, p. 16). Na releitura, cada unidade é codificada e, a seguir, individualizada.

\subsubsection{Tratamento dos Resultados Obtidos e Interpretação}

Nessa fase, os dados brutos são submetidos a operações estatísticas, a fim de se tornarem significativos e válidos e de evidenciarem as informações obtidas.

De posse das informações, o pesquisador infere e realiza suas interpretações de acordo com o embasamento teórico e os objetivos propostos, ou identifica novas dimensões teóricas sugeridas pela leitura do material.

Pode ser feita por meio da apresentação de tabelas ou quadros com indicação das distribuições de frequência e das percentagens, nas pesquisas de cunho quantitativo, ou com a produção de um "texto-síntese", nas pesquisas predominantemente qualitativas.

Assim, nesta etapa, busca-se atingir a "compreensão mais aprofundada do conteúdo das mensagens mediante inferência e interpretação" (MORAES, 1999, p. 24). A partir dessa compreensão, pode-se utilizar os resultados com fins teóricos ou práticos, bem como partir para novas análises com objetivos diversos.

Mas, como diz Triviños (1987 apud CURY, 2003), "não é possível que o pesquisador detenha sua atenção exclusivamente no conteúdo manifesto dos documentos. Ele deve aprofundar sua análise tratando de desvendar o conteúdo latente que eles possuem."

Cada pesquisador, ao deparar-se com um corpus, produz uma categorização que evidencia sua visão específica. Em cada etapa, a intuição do pesquisador, orientada pelos objetivos da pesquisa, já produz uma forma de interpretação, pois suas decisões não são neutras, trazem todas as suas concepções sobre o tema objeto de análise.

\subsubsection{Categorização}

Tendo destacado as unidades, o próximo passo é a categorização, que "tem por primeiro objetivo [...] fornecer, por condensação, uma representação simplificada dos dados brutos." (BARDIN, 2011, p. 119). Esse agrupamento é feito segundo critérios prévios, já decididos anteriormente, acrescidos de outros que são estabelecidos ad hoc.

De acordo com Bardin (2011), deve-se seguir o seguinte roteiro: constituição do corpus, preparação do material e etapas de análise (alinhamento e dinâmica do discurso 
para encontrar a lógica inerente à estrutura da mensagem, análise do estilo e análise dos elementos atípicos e figuras de retórica). O confronto entre as etapas de análise percorridas deve permitir a compreensão do seu significado.

De acordo com os objetivos almejados neste trabalho, pretende-se compreender como os conceitos são utilizados pelos elaboradores de itens da OBMEP e, por meio dos registro das sugestões de solução, recorrer à Análise de Conteúdo, por ser um instrumento de análise interpretativa que busca o sentido de um texto. Desse modo, a análise do texto de cada item e da solução apresentada pelo elaborador pode evidenciar como um instrumento avaliativo, na amostra pesquisada, apresenta características pedagógicas importantes para o ensino de Matemática.

Logo, a Análise de Conteúdo tem um papel fundamental: ela ajuda a "quebrar" a produção escrita dos elaboradores e as marcações dos estudantes. Assim, desconstruir e construir as informações para poder realizar inferências, estabelecendo-se conexões entre as informações encontradas e a intencionalidade do instrumento. 


\section{Análise do Erro}

[...] na avaliação classificatória, em que o foco de atenção está voltado para o acerto da resposta, não sendo utilizado como um instrumento de reflexão, o erro provavelmente não será valorizado pelo professor. Em outra concepção de avaliação, mais preocupada com a formação do aluno em termos de aprendizagens significativas e duradouras, o erro deixa de ser apenas uma resposta a ser analisada: ele passa a ser uma questão desafiadora que o aluno coloca ao professor - portanto, um elemento desencadeador de um amplo questionamento de ensino (SILVA; BURIASCO, 2005, p. 501).

\subsection{Errar: Uma Ação para a Aprendizagem Significativa}

Ao tomarmos uma avaliação construída a partir de itens de múltipla escolha, em que os distratores são plausíveis, ou seja, o elaborador dos itens fez um estudo prévio de caminhos errôneos de estudantes que não dominam aquilo que se pretende avaliar na situação-problema proposta e os expressou nas alternativas incorretas, temos uma avaliação que pode ser considerada pelo docente como instrumento de investigação dos erros, assim como ocorre em questões abertas ou dissertativas. Esta avaliação é certamente embasada pelos objetivos de aprendizagem, pois foi concebida previamente.

Cabe aqui um breve comentário sobre as opções incorretas presentes nas
questões de múltipla escolha. Quando essas opções são bem elaboradas, a
análise do erro pode revelar resultados muito interessantes em termos de
aprendizagem por parte dos estudantes. Muitas vezes, essas inferências
são mais ricas do que as conclusões que são extraídas do próprio acerto
no item. Podem, inclusive, ser feitas inferências de ações pedagógicas
que poderiam ser praticadas a partir do comportamento revelado nas
escolhas das opções incorretas pelos estudantes (RABELO, 2013, p. 141).

Não quer dizer que o elaborador conseguirá esgotar nas alternativas todas as formas possíveis de erros ou até mesmo confirmar que o aluno ao marcar o distrator cometeu o erro da forma que o elaborador apresentou nas soluções. Nesta abordagem, o resultado da análise será uma inferência do erro, pois o aluno pode ter tomado caminhos não previstos e até mesmo marcado a alternativa ao acaso. Mesmo sendo uma inferência, o professor terá um espectro de ações pedagógicas que contribuam para um refinamento das habilidades construídas.

Os itens apresentados desta forma nos levam a uma análise de intenção dos respondentes. Se tomarmos o acertos teremos em mão o processo findo de conhecimentos, ou seja, o que o aluno aprendeu e podemos dar continuidade no estudo de conteúdos novos. Mas se tomar os erros nas questões abertas, ou os distratores com marcação expressiva, 
poderemos dar continuidade ao conteúdo, mas com um leque de adaptações nos objetivos que levem os alunos a ressignificarem conceitos.

No momento de elaborar os itens de múltipla escolha, o caminho errôneo é usado na construção de distratores plausíveis. Após a resolução do item, os distratores podem ser contabilizados para obter resultados da amostra, quando houver uma marcação muito expressiva, pode-se ter um embasamento que justifique a alteração ou não dos objetivos. Da mesma forma, em itens abertos, os erros podem ser computados. Com os distratores tem-se inferências dos processos errôneos, mas nos itens abertos temos a confirmação dos erros, estes estarão expressos.

Com uma abordagem investigativa e questionadora nesse momento, o docente pode refazer sua prática, retomar e reconstruir objetivos. Este pode, também, confeccionar instrumentos de avaliação que sanem os erros ocasionados pela não conformidade com a Engenharia de Itens, e, além disso, o docente terá na mão instrumentos para inferir caminhos tomados pelos alunos e, assim, utilizar a avaliação proposta para aprendizagem. Ou seja, com uma ou outra fonte de erro, o professor revê sua postura frente a avaliação, reelaborando o instrumento ou revendo seu fazer didático - ele aprende com o erro.

\footnotetext{
Consideramos que a avaliação da aprendizagem matemática, em vez de ser tratada como uma interrupção do processo de ensino-aprendizagem, precisa ser entendida como um processo de investigação e, desse modo, é de fundamental importância que sejam considerados os processos e estratégias utilizadas pelos alunos nos seus registros escritos.

O tratamento da avaliação como prática de investigação tem, entre suas características mais relevantes, o fato de poder contribuir com o desenvolvimento dos alunos à medida que possibilita que estes compreendam seus erros e, a partir disso, busquem superá-los. Também contribui com o professor, favorecendo uma reflexão sobre seu planejamento, desenvolvimento e avaliação da sua prática pedagógica (SILVA; BURIASCO, 2005, p. 500).
}

Aproveitar os erros na aprendizagem não quer dizer que estes serão descartados na avaliação somativa, mas dar a importância devida aos processo errôneos na avaliação. Pode-se tomá-los de forma a investigar as formas de erro e saná-los a partir da tomada de consciência do erro com o feedback ao aluno, para que ele saiba o distanciamento com o conceito formal e também para que o aluno supere os obstáculos na sua aprendizagem.

A análise do erro também pode contribuir com o aluno na medida em que o professor o incentive a analisar sua própria produção. Com isso, o aluno terá a oportunidade de identificar e compreender seus erros, podendo assim geri-los, isto é, desenvolver processos de verificação e autocorreção que o ajudem a refazer o caminho (SILVA; BURIASCO, 2005, p. 501).

Essa superação pode ser dada pelo questionamento dos alunos frente a suas respostas. Borasi (1996 apud CURY, 2007, p. 15) assume que a análise de erros é uma me- 
todologia de pesquisa e de ensino, e esta análise é vista pela autora como um "trampolim para a aprendizagem".

A análise de erros é uma abordagem de pesquisa com fundamentações teóricas variadas, objetivos distintos e participação de todos os níveis de ensino nas amostras, mas também é uma metodologia de ensino, podendo ser empregada quando se detectam dificuldades na aprendizagem dos alunos e se quer explorá-las em sala de aula (CORREIA, 2010b, p. $17)$.

De acordo com Pinto (2000 apud CORREIA, 2010b), a reflexão sobre o erro é necessária no âmbito da pesquisa educacional, pois este tema abrange simultaneamente um saber científico - a Matemática -, um saber construído na prática em sala de aula e um saber avaliativo, ou seja, saberes que o docente irá construir na sua profissão. Logo, este tema deve ser aplicado na formação de professores já que pode gerar reflexões sobre o processo de aprendizagem.

Entre os conceitos acerca do erro, Barichello (2008 apud CORREIA, 2010b) considerao como uma parte de um produto final que não esteja de acordo com a Matemática que se espera que o aluno apresente, assim sendo, o erro fica caracterizado pela falta em relação à Matemática. E complementarmente pode ser entendido por falta na aplicação de um algoritmo para a tentativa de resolução de um problema, mas que na argumentação do aluno haja um processo lógico para ter ocasionado, desde a aplicação equivocada de conceitos até a má compreensão do enunciado. Para Correia (2010b), é importante observar que o erro é um processo de "indução" do raciocínio lógico matemático, um encadeamento do pensamento que conduz a uma falsa conclusão.

Para o aluno, o erro em geral permanece oculto até que alguém o aponte na resolução. Ao resolver um problema, mesmo obtendo resposta diferente daquela esperada, o aluno aplica estratégias que, por algum motivo, lhe parecem relevantes em termos do problema proposto. Ele não age arbitrariamente, mas, sim, de acordo com um conjunto de conhecimentos estabelecido em seu aparato cognitivo (CORREIA, 2010b, p. 18).

Se o professor explorar a dificuldade dos alunos e utilizar os erros como ferramentas para o aprendizado, elaborando estratégias que levem os estudantes a questionamentos sobre suas respostas, pode-se ter um embasamento sólido para o auto-monitoramento.

Para o aluno, a avaliação pode servir para regular sua aprendizagem, sendo subsídio capaz de orientá-lo para a autonomia de pensamento, para perceber suas dificuldades, analisá-las e descobrir caminhos para superá-las. Para o professor, deve contribuir para que ele possa repensar e reorientar a sua prática pedagógica, além de possibilitar-lhe entender e interferir nas estratégias utilizadas pelos alunos (SILVA; BURIASCO, 2005, p. 500). 
Tomar consciência, retomar e corrigir o próprio raciocínio são ações que expressam a autonomia discente. Mas a autonomia desenvolve-se a partir da interação do sujeito com seus próprios conceitos, com outros sujeitos e os objetos de conhecimento e não, apenas, com os apontamentos dos docentes. As ações educativas que a promovem estão associadas às bases da construção do conhecimento e do desenvolvimento cognitivo.

\subsection{Erro: Bases Históricas}

Cury (2003) apresenta que as pesquisas acerca dos erros cometidos pelos alunos em disciplinas matemáticas foram iniciadas em trabalhos desenvolvidos no início do século $\mathrm{XX}$, nos quais a concepção do erro estava de acordo com a teoria educacional vigente, ou seja, ora eram priorizados os aspectos técnicos dos erros, ora as teorias psicológicas, de ensino ou de aprendizagem. De acordo com Barichello (2008 apud CORREIA, 2010b), desde o princípio destes estudos há a ênfase na proposição de sistemas de classificação para os erros em Matemática cometidos por estudantes em diversos níveis.

Segundo o educador matemático Rico (1995 apud CORREIA, 2010b), as pesquisas sobre o erro e sua análise ao redor do mundo apresentam importantes contribuições para esta área.

De acordo com esse autor, por exemplo, na Alemanha no período entre as duas grandes guerras mundiais, com o desenvolvimento da psicologia experimental, o erro, nos trabalhos de Weiner em 1922, era utilizado para estabelecer padrões explicativos para os equívocos individuais em diferentes idades. Já nos estudos de Kiessling em 1925, o erro era determinado pela predisposição que algumas pessoas tinham em se equivocar. Já em 1931, Seseman distinguiu três tipos de erros: mecânicos, associativos e funcionais.

Rico destaca que, a partir dos anos 60, a linha de pesquisa era de investigação quanto às deficiências no cálculo aritmético, buscando descobrir causas de erros nas fases do processo de solução. Erlwanger, em 1975, e Ginsburg, em 1977, influenciaram o ensino de Matemática por meio de suas investigações sobre as estruturas básicas dos processos de ensino e aprendizagem, empregando como método de investigação as entrevistas clínicas e os estudos de casos.

Rico (1995) descreve que na Espanha, a partir de 1953, Villarejo e Fernández Huerta investigaram os erros mais frequentes na aritmética escolar e, na União Soviética, nos anos 60, dois trabalhos sobre as causas dos erros nas operações fundamentais merecem citação. Primeiramente, o de Kuzmitskaya que localiza quatro causas de erros nas operações aritméticas:

1. insuficiência de memória de curto prazo;

2. compreensão insuficiente das condições do problema; 
3. ausência de regras verbais para realização de cálculos;

4. uso incorreto das quatro operações.

Posteriormente, os estudos de Menchinskaya destacam, da mesma forma, quatro causas:

1. a realização incorreta de uma operação;

2. a compreensão conceitual insuficiente;

3. a distração, que provoca erros mecânicos;

4. a aplicação indevida das regras algorítmicas.

Nos Estados Unidos, de acordo com Rico (1995), o trabalho de Thorndike em 1917, intitulado "Psicologia da Aritmética", se caracteriza como pioneiro nos estudos acerca dos erros que ocorreram nas operações aritméticas fundamentais, enquanto Buswell conseguiu detectar um maior número de erros típicos pelo método de análise, incluindo, ao lado de exercícios escritos, observações em aula e entrevista para diagnóstico. Brueckner, em 1935, propunha alguns objetivos para o trabalho com os erros:

(a) listar as técnicas errôneas;

(b) determinar a distribuição de frequências dessas técnicas, segundo as idades dos alunos;

(c) analisar dificuldades especiais, como as encontradas na divisão e nas operações com o zero;

(d) classificar e agrupar os erros.

A linha psicométrica utilizada nessas investigações iniciais influenciou as avaliações da aprendizagem. Entre os seguidores dessa linha de pesquisa surgem os trabalhos de Tyler e Bloom, que são os autores que mais introduziram mudanças substanciais no modo de avaliar os alunos, com as ideias de que as provas devem seguir certos critérios e de que os objetivos de cada disciplina devem servir como padrões avaliativos (CORREIA, 2010b, p. 21).

Esse autor ainda lembra que, como aponta Gutierrez em 1991, com o avanço da didática da Matemática, principalmente na França e na Espanha, aumentou o interesse pela investigação dos erros cometidos pelos alunos. 


\subsection{O Erro e o Ambiente Construtivista}

De acordo com Pinto (2000 apud CORREIA, 2010b, p. 22), "a nova concepção do erro, a partir dos fundamentos psicogenéticos, é encontrada, com mais profundidade, na literatura sobre o construtivismo". À luz do construtivismo, os erros que se apresentam no processo de desenvolvimento da criança denotam a apropriação dos conhecimentos. Segundo essa autora, entre outros, os trabalhos de Macedo e La Taille, utilizam essa teoria para discutir o papel construtivo do erro da criança.

Na sua definição geral, construtivismo refere-se a um conjunto de teorias que afirmam que a evolução da inteligência é fruto da interação do sujeito com seu meio, interação na qual, por meio de um trabalho ativo de ação e reflexão, ele cria ferramentas cada vez mais complexas para conhecer o universo (CORREIA, 2010b, p. 22).

De acordo com Macedo (1994 apud CORREIA, 2010b, p. 23), para Piaget o erro é um elemento possível e até necessário que faz parte do processo no qual está se construindo um conceito, ou seja, é um erro construtivo, onde a criança é capaz de refletir sobre o mesmo.

\footnotetext{
O que se espera hoje, de acordo com essa visão, é conceber o erro como um meio de desenvolvimento. É importante que primeiro se entenda a situação que o motiva para depois procurar meios de superá-lo. Desse modo, é necessário que o professor busque conhecer e entender os erros cometidos pelos alunos nas atividades propostas, já que, “(...) quando um aluno comete um erro, ele expressa o caráter incompleto de seu conhecimento" (SILVA; BURIASCO, 2005, p. 501).
}

Teixeira (1997) cita Piaget e Vergnaud, afirmando que o primeiro diz que para haver compreensão do processo de construção do conhecimento, é necessário analisar o desenvolvimento das estruturas lógicas gerais; o segundo autor aponta que, para compreender a construção do conhecimento, não é suficiente observar o processo, mas é preciso transformá-lo. Daí, ao tomarmos a noção de erro na aprendizagem, retiramos a noção de ser uma ação fracassada, mas que carrega em si estruturas com raciocínios lógicos observáveis e que podem ser reelaborados para a aprendizagem do indivíduo em formação.

Também na abordagem piagetiana, no processo de construção das estruturas lógicas, os erros, segundo Piaget (TEIXEIRA, 1997, p. 49), são resultados de conflitos cognitivos onde os indivíduos se esforçam para se adaptarem a novos contextos.

Conflito cognitivo para Piaget é o termo usado para explicar o processo através do qual ocorrem mudanças cognitivas, ou seja, passagem de um estado de equilíbrio a outro (teoria da equilibração, através de um período de transição em que há formas contraditórias de interpretar e resolver um mesmo problema) (TEIXEIRA, 1997, p. 49). 
Segundo Piaget (1991 apud CORREIA, 2010b, p. 23), não interessa o erro, mas a ação mental; erro e acerto são detalhes nessa ação mental. Nesta perspectiva, as respostas dos indivíduos são apresentadas, ordenadas e classificadas em três níveis:

- no primeiro nível, o indivíduo não resolve e nem compreende o erro, por isso as respostas contraditórias são negadas e recalcadas; não lhe causa problema responder errado, pois não houve entendimento do problema proposto;

- no segundo nível, o da tentativa, o erro aparece como um problema a ser resolvido. São comuns a ambivalência e a dúvida; nesta situação, a interferência adulta ou de colega possibilita à criança avanço e a percepção do conflito em suas respostas;

- no terceiro nível, o erro passa a ter um sentido ao aluno, e este adquire certa autonomia na construção do conhecimento e na construção do conhecimento. Apresenta-se uma resposta satisfatória para o problema, conseguindo o aprendiz antecipar-se e corrigir-se. Neste caso, consegue-se sucesso com relativa autonomia frente às situações.

Se numa avaliação seletiva, o erro tem um papel delimitado pelos resultados, ao perder sua função controladora, ele passa a ocupar um papel relevante na aprendizagem: o erro é um conhecimento; ele mostra o caminho do acerto que já está ali implícito. Nesta dialética, o erro aparece como um divisor de águas de duas tendências fortes na educação. Se na pedagogia tradicional, centrada no professor, o relevante era saber o que se ensina na pedagogia nova a preocupação do professor é saber como as crianças aprendem (CORREIA, 2010b, p. 25).

A ação errônea é o apontamento de um problema que suscita novas soluções, ao mesmo tempo em que é uma resposta a determinada questão, onde no início se apresentava como obstáculo, mas contribui para a maturação e reestruturação de processos cognitivos mais elaborados.

Os níveis, apresentados por Piaget, possibilitam a compreensão das respostas em função da estruturação cognitiva do sujeito, favorecendo o trabalho dos erros dentro da história dos alunos. Por isso, o erro, na perspectiva infantil, difere da concepção que tem a perspectiva adulta. Para a criança, não está em jogo somente o certo ou errado, mas também a possibilidade de sua compreensão.

Para contribuir com o estudo destes níveis, Rosso acrescenta que:

No primeiro nível são erros derivados da limitação das estruturas necessárias à solução da tarefa, ficando a criança impossibilitada de compreender o que lhe é solicitado; no segundo, são erros construtivos, porque sinalizam a formação de novas estruturas; no terceiro são erros de procedimento, cometidos no emprego ou aprimoramento de conhecimentos já construídos e que podem acontecer por distração ou falta de habilidade. 


\begin{abstract}
No primeiro e segundo níveis, as dificuldades são operativas, exigindo procedimentos didático-pedagógicos mobilizadores dos processos operativos e cooperativos. Já no terceiro nível são obstáculos epistemológicos por se apoiarem em conhecimentos anteriores, devendo a ação docente promover conflitos que ponham em xeque a pertinência dessas informações (ROSSO; BERTI, 2010, p. 1010).
\end{abstract}

Com estas abordagens sustenta-se a prática docente de intervenção no processo de ensino-aprendizagem. Ao construir um instrumento avaliativo, o professor deve levar em consideração estes níveis de erro, até mesmo para construir os distratores, pois ao perceber a marcação pelo aluno, já pode identificar o nível de percepção que o estudante possui em relação ao conteúdo apresentado.

E mais ainda, no momento de correção e retomada da atividade, o professor pode intervir nestes níveis em um trabalho quase que individual para reduzir o distanciamento aos conceitos corretos. Para Taille (1997 apud CORREIA, 2010b, p. 26) "não basta o aluno ficar sabendo que errou! Ele deve ter acesso à qualidade de seu erro". Mas "tornar o erro um observável nem sempre é fácil e pede muita criatividade pedagógica por parte dos professores".

Qualquer que seja a perspectiva que o erro seja abordado na escola, é necessário distinguir os erros e utilizar condutas pedagógicas apropriadas, já existentes, na busca de superação dos mesmos. A proposta de uma análise atenciosa da produção escrita dos alunos busca levar professor e aluno a enxergarem o erro como indicador de algo que precisa ser revisto e neste momento a investigação aparece para dar conta das indagações que muito provavelmente vão aparecer durante o processo de análise. Cury destaca:

A ideia de que o erro se constitui como um conhecimento, é um saber que o aluno possui, construído de alguma forma, e é necessário elaborar intervenções didáticas que desestabilizem as certezas, levando o estudante a um questionamento sobre as suas respostas (CURY, 2007, p. 80).

Análise ou correção de um item pelo professor gera alguns questionamentos acerca do raciocínio do aluno; o que e o como pensou o aluno no momento e na situação propostos, as operações que sustentam seu raciocínio, as representações, práticas cotidianas, quais conceitos tentou utilizar e outras questões. O apanhado de respostas a estas perguntas apresenta aos estudantes quais conhecimentos demonstram ter e quais ainda estão em construção.

Nesse sentido, a suposta estratégia errônea pode ter sido elaborada com base em algum conceito equivocado que esse aluno construiu, ou por tentar propor uma estratégia que contornasse sua dificuldade na resolução, seja a dificuldade com qualquer conceito matemático. 
Na perspectiva de construção de distratores, o docente se antecipa na inferência de erros que poderão ocorrer, traça uma visão geral dos possíveis quadros que os discentes construirão e, com essa postura, já revela-se em sua prática a preocupação com o refazer dos conceitos. Demonstrará que sabe o fazer didático, e ao perceber esta postura o aluno poderá tomar seus julgamentos e confiar na orientação de seu professor.

É importante que o aluno construa suas próprias ferramentas para resolver problemas. Contudo, há erros na resolução que nascem do estabelecimento de conexões entre conceitos aprendidos ou estratégias utilizadas que não se aplicam à situação- problema proposta. São falsas generalizações, são regras que não são verdadeiras.

Para justificar os caminhos errôneos que acompanham o estudante em suas respostas, é necessário tomar os conceitos de Brousseau (TEIXEIRA, 1997, p. 50). Este autor apresenta "que os erros, em um mesmo sujeito, comparecem ligados entre si por uma fonte comum: um conhecimento antigo que foi eficiente em certas situações", sendo que estes podem ser resistentes e ressurgir várias vezes.

Com base nesta análise, Brousseau (TEIXEIRA, 1997) utiliza a ideia de obstáculo, ampliando-a para interpretar questões da didática da Matemática. O autor aponta três tipos de obstáculos: epistemológicos, didáticos e ontogenéticos.

(a) os obstáculos epistemológicos se encontram tanto no desenvolvimento histórico dos conceitos, como se repetem nos conceitos espontâneos dos alunos. São concepções constitutivas do conhecimento e inerentes a um sistema de conhecimentos. Assim, todo conhecimento é suscetível de ser um obstáculo à aquisição de novos conhecimentos, na medida em que quanto mais sedimentado, maior resistência oferecerá à ampliação do conhecimento. Não são meras dificuldades. Brousseau aponta algumas condições que permitem identificar os obstáculos epistemológicos:

i. é conhecimento e não ausência do mesmo;

ii. o conhecimento-obstáculo é eficaz para certos contextos mas para outros conduz a erros;

iii. resistente ao estabelecimento de novo conceito ou ampliação do mesmo;

iv. resiste às contradições com os quais é confrontado.

(b) Obstáculos de origem didática são aqueles que dependem da escolha de um projeto educativo, ou seja, "concepções de ensino que redundam numa transposição didática".

(c) Obstáculos de origem ontogenética são os provenientes das limitações do sujeito num dado momento de aprendizagem. Podemos citar, como exemplo, a dificuldade de entender a operação de adição nos inteiros como associação e não como acréscimo. 
Se o erro for usado como motor de ação e reflexão em situações apropriadas, fazendo o aluno evoluir, reestruturando e integrando seus conceitos anteriores com a necessidade de expansão dos mesmos, os erros serão de papel positivo na aprendizagem.

Com essa abordagem, afirma Perrin-Giorian,

a noção de obstáculo é também um meio de olhar de outro modo os erros do aluno: certos erros, recorrentes são resultado de conceitos que, mesmo quando são falsos, não são acidentes mas aquisições muitas vezes positivas (TEIXEIRA, 1997, p. 51).

\subsection{Enfoque Pedagógico do Erro}

As recentes abordagens cognitivas sobre o erro passaram a encará-lo como integrante do processo de aprendizagem. Isto não significa estabelecer uma pedagogia do erro, mas uma pedagogia que assuma a presença de obstáculos na construção do conhecimento como parte do processo.

Conhecer os erros e criar estratégias visando auxiliar os alunos a superá-los deve ser uma preocupação incluída no planejamento do professor. O professor precisa analisar os erros dos alunos e categorizá-los, para entender como o processo de aprendizagem está ocorrendo para seus ouvintes.

Assim, no momento da correção, ao verificar conclusões errôneas, o professor faz inferências das premissas utilizadas, caracterizando a natureza dos erros produzidos. A partir daí tomará decisões que retomem aprendizagem do conceito formal. "Ao levantar indícios sobre o desempenho dos alunos, o professor deve ter claro o que pretende obter e que uso fará desses indícios. Nesse sentido, a análise do erro pode ser uma pista interessante e eficaz" (BRASIL, 2000, p. 59).

Os erros apontados são de naturezas diferentes e, por isso, precisam ser tratados de forma diferenciada pelo professor. Assim, é importante que o professor identifique os diferentes tipos de erros, distinga qual a natureza de cada um deles, bem como que ações precisa realizar para explorá-los. De acordo com os PCN:

\footnotetext{
Quando o professor consegue identificar a causa do erro, ele planeja a intervenção adequada para auxiliar o aluno a avaliar o caminho percorrido. Se, por outro lado, todos os erros forem tratados da mesma maneira, assinalando-se os erros e explicando-se novamente, poderá ser útil para alguns alunos, se a explicação for suficiente para esclarecer algum tipo particular de dúvida, mas é bem provável que outros continuarão sem compreender e sem condições de reverter a situação (BRASIL, 2000, p. 59).
}

Ao tomar uma avaliação para a aprendizagem deve-se embasar em objetivos claros de aprendizagem, Bodin (1997 apud BURIASCO, 2000, p. 11), apresenta que existem 
quatro patamares onde se identifica o erro diante à construção de conhecimento em uma situação didática de Matemática:

1. erros de saber: o aprendiz não tem conhecimento matemático sobre as definições, as regras, os algoritmos, e outros;

2. erros de saber-fazer: o aprendiz não tem domínio da técnica de resolução, do algoritmo, e outros;

3. erros ligados à utilização adequada ou não dos saberes ou do saber-fazer: o aprendiz não reconhece o conceito correto para aplicar na resolução de uma situaçãoproblema;

4. erros de lógica ou de raciocínio: o aprendiz confunde hipótese e tese, encadeia mal os cálculos, não sabe lidar com os dados apresentados.

Radatz (1979 apud CURY, 2007, p. 27) propõe a seguinte classificação de erros de acordo com um modelo embasado nos mecanismos do processamento de informação:

(a) erros devido a dificuldade de linguagem: ou seja, relacionado ao formalismo simbólico;

(b) erros devido a dificuldade de obter informação espacial: relacionado à falta de capacidade de visualização de diagramas, figuras, "instruções icônicas";

(c) erros devido ao domínio deficiente de conteúdos, fatos e habilidades consideradas como pré-requisitos;

(d) erros devido a associações incorretas ou rigidez de pensamento, tanto conceitual anterior quanto no uso de uma regra a caso específico;

(e) erros devido a aplicações de regras ou estratégias irrelevantes, o uso inadequado de estratégias de solução.

Esta apresentação de categorização não implica a dissociação dos erros entre si, sendo que estes podem ocorrer de forma conjunta. O mesmo autor reforça estas associações:

...é difícil fazer uma separação entre as possíveis causas de um dado erro, porque há uma estreita interação entre as causas. O mesmo problema pode originar erros de diferentes origens e o mesmo erro pode ser proveniente de diferentes processos de solução de problemas. Uma classificação e hierarquia precisa das causas dos erros parece impossível de ser realizada (CURY, 2007, p. 28). 
Clements (1980 apud CURY, 2007, pg. 28) apresenta também os tipos de erros apontados por Newman e Casey. O primeiro propôs um modelo de sequência de passos para solucionar um problema de Matemática, em que o aluno apresenta uma só dificuldade, e que, durante o processo de solução, podem haver três causa prováveis do erro: a motivação, a desatenção e a formulação da questão em alguns destes passos. De acordo com Newman, as etapas são:

- leitura;

- compreensão;

- transformação;

- execução das habilidades necessárias ao processo;

- codificação.

Casey modificou e ampliou a classificação de Newman, tornando-a aplicável à análise de erros em problemas com mais de uma dificuldade. Para Casey, as etapas sugeridas por Newman apresentam uma rigidez e, no entanto, o aluno, ao se deparar com um item para ser solucionado, retoma ou salta passos, e nem sempre obedece uma ordem estabelecida. Este autor preconiza que a formulação é o primeiro momento de interação entre o problema a ser resolvido e o respondente, e ainda salienta que os erros que escapam a essa classificação foram agrupados em duas categorias, as quais Casey chamou de "bloco conhecido" e "bloco desconhecido".

Sua classificação para as causas dos erros é a seguinte (CURY, 2007, p. 28):

1. formulação da questão;

2. leitura;

3. compreensão;

4. seleção de estratégias;

5. seleção das habilidades requeridas;

6. manipulação das habilidades;

7. apresentação da solução.

Aqui se justifica o uso da Engenharia de construção de itens, para que a má formulação da questão não seja responsável pelos erros dos respondentes, mas que os erros que por ventura venham a ocorrer sejam intrínsecos do indivíduo. Assim, poderão ser norteadores do processo de aprendizagem dos mesmos. 
Quando se toma a análise de erros como metodologia de pesquisa, Radatz (1979 apud CURY, 2007, p. 31) apresenta uma revisão dos trabalhos feitos desde o início do século e, mesmo sem explicar o que significa cada um dos objetivos de estudo citados, considera que o interesse das pesquisas está localizado em:

(a) listar todas as técnicas potenciais de erros;

(b) determinar as distribuições de frequências destas técnicas de erros através das faixas etárias;

(c) analisar dificuldades especificas, encontradas na prática ao fazer divisões escritas e operações com zero;

(d) determinar a persistência das técnicas individuais de erros;

(e) tentar classificar e agrupar erros.

Borasi (1996 apud CURY, 2007) propõe um esquema de categorização (apresentada na Tabela 7) dos usos dos erros para o ensino, de acordo com o objetivo da aprendizagem e ação interventiva.

Tabela 7 - Taxonomia de Borasi para os Usos de Erros

\begin{tabular}{|c|c|c|c|}
\hline & $\begin{array}{l}\text { Realização de uma tarefa } \\
\text { matemática específica }\end{array}$ & $\begin{array}{l}\text { Compreensão de algum } \\
\text { conteúdo técnico- } \\
\text { matemático }\end{array}$ & $\begin{array}{l}\text { Compreensão sobre a na- } \\
\text { tureza da Matemática }\end{array}$ \\
\hline Remediação & $\begin{array}{l}\text { Análise dos erros detectados, } \\
\text { para compreender o que houve } \\
\text { de errado e corrigir, de forma a } \\
\text { realizar a tarefa com sucesso. }\end{array}$ & $\begin{array}{l}\text { Análise dos erros detecta- } \\
\text { dos, para esclarecer más } \\
\text { interpretações de um con- } \\
\text { teúdo técnico matemático. }\end{array}$ & $\begin{array}{l}\text { Análise dos erros detectados, } \\
\text { para esclarecer más interpreta- } \\
\text { ções sobre a natureza da Mate- } \\
\text { mática ou de conteúdos especí- } \\
\text { ficos. }\end{array}$ \\
\hline Descoberta & $\begin{array}{l}\text { Uso construtivo de erros no } \\
\text { processo de resolução de um } \\
\text { novo problema ou tarefa; mo- } \\
\text { nitoramento do trabalho de al- } \\
\text { guém para identificar potenci- } \\
\text { ais enganos. }\end{array}$ & $\begin{array}{l}\text { Uso construtivo de erros ao } \\
\text { aprender novos conceitos. }\end{array}$ & $\begin{array}{l}\text { Uso construtivo de erros ao } \\
\text { aprender sobre a Natureza da } \\
\text { Matemática ou de algum con- } \\
\text { ceito matemático }\end{array}$ \\
\hline Pesquisa & $\begin{array}{l}\text { Erros e resultados intrigantes } \\
\text { motivam questões que geram } \\
\text { pesquisas em novas direções e } \\
\text { servem para desenvolver novas } \\
\text { tarefas matemáticas. }\end{array}$ & $\begin{array}{l}\text { Erros e resultados intrigan- } \\
\text { tes motivam questões que } \\
\text { podem levar a novas pers- } \\
\text { pectivas sobre um conceito } \\
\text { regra ou tópico não con- } \\
\text { templado no planejamento } \\
\text { original. }\end{array}$ & $\begin{array}{l}\text { Erros e resultados intrigantes } \\
\text { motivam questões que podem } \\
\text { leva a insights e perspectivas } \\
\text { inesperadas sobre a natureza } \\
\text { da Matemática ou de algum } \\
\text { conteúdo matemático. }\end{array}$ \\
\hline
\end{tabular}

Estes apontamentos de Borasi embasam as atitudes do professor frente ao erro diante aos objetivos da aprendizagem e das atividades desempenhadas, e a autora enfatiza que as formas de utilização podem aparecer separadas ou combinadas. "Assim dependendo dos objetivos com que o erro é empregado e do nível de abstração com que é examinado, podemos transitar por essas diversas formas de se trabalhar com análise de erros" Borasi (1996 apud CURY, 2007, p. 40). 
Na verdade é necessário conceber o erro como um meio de desenvolvimento da aprendizagem: ao final da categorização, o professor toma ações fundamentadas na tipologia do erro para haver reconstrução do conhecimento. Segundo Buriasco (2000, p. 169), grande “(...) parte dos educadores matemáticos enfatiza que em lugar de ser protegido do erro, o aluno deveria ser exposto ao erro muitas vezes, ser encorajado a detectar e a demonstrar o que está errado, e por quê".

Rosso e Berti (2010, p. 1007) determinam que o erro envolve, a priori, três enfoques:

1. o enfoque epistemológico, pois o erro pressupõe concepções sobre a construção do conhecimento e a sua adaptação à realidade;

2. o enfoque psicológico, referindo-se na visão dos estudantes ao significado das atitudes envolvidas, da interpretação das correções e do valor dado ao erro e ao conhecimento matemático;

3. o enfoque pedagógico, que relaciona as ações assumidas pelo docente diante do erro e das estratégias usadas para uma aprendizagem significativa.

Partindo dos enfoques epistemológico e psicológico, a resposta errônea serve como ponto de partida para novas investigações que levarão o indivíduo a buscar soluções que satisfarão não apenas a situação proposta, mas também servirão como resposta a outras proposições.

O professor, levando em consideração o enfoque pedagógico do erro juntamente com o epistemológico e psicológico, terá maiores possibilidades de reelaborar sua prática de sala de aula, pois poderá buscar novos recursos e metodologias que têm como foco não o repasse, mas a construção do conhecimento por meio do questionamento e da autorreflexão.

Desse modo, o erro se constitui importante instrumento de intervenção didática, pois, a partir dele, o docente tem a possibilidade de observar e valorizar a diversidade na sala de aula, o diálogo e a troca de ideias e consequentemente escolher a conduta a ser utilizada no ensino de determinado conteúdo.

\subsection{Erro e a Avaliação de Larga Escala}

A análise do erro em sala de aula pode ocorrer de forma significativa ao utilizar questões abertas ou de múltipla escolha, mas, para uma avaliação de larga escala, o segundo uso é mais factível, devido ao grande número de envolvidos no estudo.

Em uma avaliação de larga escala, o uso de distratores plausíveis possibilitará um retorno ao docente da sua ação pedagógica, ao mesmo tempo em que estes podem 
constituir fonte para índices de aprendizagem nacionais, dando ao Estado um respaldo para as políticas educacionais que contribuam para uma democratização, de fato, do ensino.

E a ação, que os resultados apresentados pela análise gerarão frente aos indivíduos, em estudo, será realizada pelo docente, mas com o aparato do Estado. Com uma lente de aumento, utilizando um bom instrumento avaliativo, o Estado poderá observar o conhecimento sendo construído e intervir de acordo com os objetivos gerais da avaliação, por meio do professor.

Não se pode deixa de destacar também o papel do aluno nesta construção. Pinto (2000) aponta que o trabalho com o erro se desenvolve a partir do momento em que ele se torna observável, tanto pelo aluno quanto pelo professor, e coloca que no processo de aprendizagem o "aluno deve perceber a qualidade do erro, interagindo com ele, desequilibrando suas estruturas mentais, por meio dele, até poder superá-lo" (PINTO, 2000, p. 147).

Desse modo, a participação do aluno na análise dos erros, por meio do feedback do seu trabalho, é essencial para que a ação interventiva do professor possibilite que o aluno se coloque diante dessas ações como elemento ativo no processo de aprendizagem, atuando, reconhecendo e dando significados aos erros apresentados.

[...] de modo geral os erros devem ser vistos como um indicativo de que o aluno sabe alguma coisa, porém não totalmente ou corretamente e que, portanto, é preciso trabalhar com esses erros e não apenas ignorá-los, lembrando que, dependendo da natureza do erro e que se determina qual conduta pedagógica deve ser adotada na busca de sua superação. Essa é uma das contribuições pessoais que o professor pode fazer na busca de diminuir o fracasso escolar (BRASIL, 2001, p. 55) ${ }^{1}$.

As situações de erro também podem servir ao aluno como meio de reflexão sobre o que ele pensa de determinado assunto, para perceber que a partir delas também se pode aprender. Para que isso aconteça, é importante que, em sala de aula, o aluno seja incentivado e tenha a oportunidade de realizar tentativas, sabendo que estas, "corretas ou não", serão do mesmo modo fonte de aprendizagem.

\footnotetext{
Para que a análise do erro se torne uma alternativa didática, o professor deve conhecer e buscar compreender o erro, investigando sua natureza, tendo em vista que "(...) os erros da aprendizagem, (...)" servem positivamente de ponto de partida para o avanço, na medida em que são identificados e compreendidos, e sua compreensão é o passo fundamental para sua superação (SILVA; BURIASCO, 2005, p. 501).
}

$1 \quad$ AVA (Programa de Avaliação do Sistema Educacional do Paraná) da Secretaria de Estado de Educação que contém 30 questões que avaliaram os alunos concluintes da $4^{\mathrm{a}}$ série do Ensino Fundamental em Matemática em 2000 
Assim, é necessário que todos os envolvidos na avaliação educacional, desde o Estado até o aluno, percebam que a avaliação é uma dimensão do processo ensinoaprendizagem, uma aliada para ambos no processo de desenvolvimento.

\begin{abstract}
Em um país que só se implanta com continuidade aquilo que é fruto de política de Estado (e não de governo), não se pode dispensar os processos de avaliação feitos no âmbito do poder público. Muito menos podemos colaborar para sua desresponsabilização quanto à avaliação feitos no âmbito do poder público. Entretanto, é legítimo discordar da forma como alguns governos querem conduzir os processos avaliativos (FREITAS, 2014, p. 47).
\end{abstract}

No tocante aos instrumentos de avaliação em larga escala, a avaliação do Enem - Exame Nacional de Ensino Médio - é um exemplo de provas que sofreram alterações significativas na sua elaboração e podem ser utilizadas por professores e alunos para uma ressignificação da aprendizagem. Com distratores bem elaborados podem ser usadas para comparação dos estudantes no tempo e já trazem em si um caráter de acompanhamento de competências construídas no ensino superior, pelo Sinaes - Sistema Nacional de Avaliação da Educação Superior.

Com o intuito de contribuir na elaboração da prova de primeira fase da OBMEP, no Capítulo 8.3 será apresentado um estudo acerca da elaboração deste instrumento e sobre a aplicabilidade da análise de erro sobre os distratores no grupo analisado. A intenção não é valorizar o erro, mas dá-lhe uma nova função no processo de ensino-aprendizagem. É a preocupação com o caminho percorrido pelo aluno que, consequentemente, o levou a errar que deve estar em questão e se houve problemas na elaboração e/ou se as habilidades necessárias para responder os itens devem ainda ser exploradas pelos docentes. 
Parte II

Análise e Discussão 



\title{
7 Metodologia
}

\begin{abstract}
O que se espera de uma avaliação numa perspectiva transformadora é que os seus resultados constituam parte de um diagnóstico e que, a partir dessa análise da realidade, sejam tomadas decisões sobre o que fazer para superar os problemas constatados: perceber a necessidade do aluno e intervir na realidade para ajudar a superá-la (VASCONCELLOS, 2005, pg. 89).
\end{abstract}

Este trabalho começou a ser realizado em agosto de 2014, após a aplicação da primeira fase da OBMEP, a respeito da qual se delineou o objeto de estudo aqui apresentado. Entre as fases e níveis da Olimpíada, foi escolhido o instrumento de avaliação da primeira fase do nível 2, sendo o público alvo os alunos que cursam o oitavo e o nono ano do ensino fundamental.

A escolha da primeira fase foi motivada pela possibilidade de análise de um instrumento composto de itens de múltipla escolha, no qual os distratores, ou alternativas de respostas erradas, podem evidenciar os caminhos errôneos utilizados pelos respondentes, constituindo-se ferramenta pedagógica de grande valia para os professores que atuam nessa etapa de escolaridade. Já a motivação principal de escolha do nível, reside no fato de a pesquisadora atuar efetivamente no ensino fundamental, nesses anos em particular.

O levantamento de referencial teórico bibliográfico foi o segundo passo de elaboração deste estudo, iniciado com uma investigação sobre o regulamento, a relevância e fatos históricos relacionados à Olimpíada Brasileira de Matemática das Escolas Públicas e a importância de uma avaliação de larga escala para a aprendizagem.

Também foram realizadas reuniões e conversas informais junto aos coordenadores da OBMEP para confirmação de informações relativas ao certame e que não estavam disponíveis no sítio do evento, gerando, assim, o acesso a RAIG de 2014 e uma entrevista com o coordenador de elaboração dos itens, via correio eletrônico, que mais tarde foram cedidas para o estudo.

O levantamento de bibliografias continuou com o estudo das teorias psicométricas e estatísticas - a TRI e a TCT -, com o estudo da Engenharia de Construção de Itens e a abordagem de Análise de Conteúdo e, por fim, com a análise de erros no processo de ensino-aprendizagem.

\subsection{Coleta de dados - estudo quantitativo}

Para investigar as respostas dos estudantes, foram escolhidas cinco escolas do Distrito Federal, situadas nas seguintes Regiões Administrativas: Brasília (duas), Ceilândia, 
Recanto das Emas e São Sebastião. Nesses locais, todos os alunos realizaram a prova da OBMEP - nível 2 (Anexo B), e foram relacionados 1.658 estudantes no total.

Foi requisitado junto ao professor coordenador da OBMEP na escola, a cessão dos gabaritos dos estudantes. Estes foram mantidos na escola após a seleção dos candidatos para segunda fase e cedidos para estudo, com a responsabilidade de retorno dos mesmos a cada instituição. Para isso, foi redigido um Termo de Consentimento Livre e Esclarecido (Apêndice A), que estabelecia o objetivo do estudo e a necessidade de uso das respostas dos estudantes, e, ainda, evidenciava a responsabilidade de não se divulgar o nome das escolas nem os dados referentes aos alunos.

Em duas escolas, havia 100\% das folhas de respostas respondidas pelos estudantes, mas as folhas dos $5 \%$ escolhidos para segunda fase eram cópias escaneadas e as demais correspondiam aos originais. Para as demais escolas, os gabaritos eram referentes aos alunos não selecionados.

Os gabaritos foram numerados e separados em cinco grupos, mantendo-se sigilo quanto à identidade da escola e do estudante. A pesquisadora retornou ao material apenas para efeito de verificação de alguma divergência na digitação ou para comparar o resultado com os escores determinados pelos corretores escolares.

Os dados foram tabulados em planilha eletrônica do software EXCEL, com a seguinte discriminação: identificação numérica do aluno, sexo, ano de ensino, 20 respostas marcadas em cada item e escore bruto obtido. Caso houvesse dupla marcação ou questão em branco, no campo referente ao item foi colocado um ponto ( . ) - posteriormente foi denominada marcação em branco.

Esse arquivo citado foi convertido para uma novo arquivo intitulado BancodeDados.xls, no qual as informações referente a sexo, ano de ensino e escore bruto foram retiradas. Com contribuição de macros desenvolvida pelo CEBRASPE - Centro Brasileiro de Pesquisa em Avaliação e Seleção e de Promoção de Eventos - foram elaborados os resultados a partir da TCT. Estes resultados são apresentados em tabelas e gráficos individuais por item, no Capítulo 8, logo após o enunciado do respectivo item.

Cada uma dessas tabelas possui os seguintes dados: número da questão, gabarito do item, dificuldade, índice de discriminação do item, coeficiente bisserial do item, coeficientes bisseriais de cada alternativa e porcentagem de marcação por alternativa, inclusive da marcação em branco.

Foram também construídas as AGI de cada item, nas quais, no eixo das abscissas, foram inseridos os escores brutos alcançados pelos estudantes, enquanto no eixo das ordenadas há a porcentagem de marcação de cada alternativa de acordo com o escore de cada grupo de estudantes. As curvas presentes nas AGIs demonstram as marcações de cada alternativa pelo grupo de estudantes que responderam o teste, de acordo com as faixas 
de escores brutos totais do teste, além daquela correspondente à marcação em branco.

Estas macros foram elaboradas no EXCEL, em arquivo intitulado TCTOBMEP.xls, que possuía a planilha de banco de dados convertida agora em tabela de zeros e uns, na qual cada item certo recebia o valor 1 e cada item errado recebia o valor 0 , objetivando verificar o escore obtido e formalizar os dados quantitativos do estudo. Além disso, esta última planilha foi usada em outro arquivo intitulado GraficoTCT.xls, que possuía a macro para gerar a AGI de cada item. Ao final, as AGIs foram salvas como figuras em arquivo PDF.

A parceria realizada com o CEBRASPE ainda possibilitou a análise utilizando-se o software BILOGMG 1.0, que gerou os parâmetros segundo a TRI: a discriminação, a dificuldade do item, o acerto ao acaso e a proficiência dos estudantes, tanto na escala 0-1, quanto na escala 500-100, modelo utilizado no ENEM. Além disso, foram geradas as CCIs. Esses dados podem ser utilizados para confirmar algum apontamento, mas principalmente serão utilizados em estudos futuros.

A parceria acima foi requisitada junto à Coordenação de Avaliação e Pesquisa, por meio de documento (Apêndice B). Um profissional competente acompanhou todos os procedimentos junto com a autora deste estudo, durante 8 horas, no departamento do próprio órgão, além de orientar nas atividades externas relativas à análise dos dados.

\subsection{Coleta de dados - estudo qualitativo}

Como os itens da prova são de múltipla escolha, deve-se analisar a construção dos itens e de seus distratores com base na Engenharia de Construção de Itens (Capítulo 4) com o objetivo de haver um confronto entre a teoria apontada e o instrumento de avaliação, verificando se a elaboração do item pode interferir no desempenho do estudante durante a realização da prova. E, além disso, verificar se o instrumento, diante da amostra, pode ser utilizado como fonte de investigação com relação aos erros dos estudantes. Esses erros foram inferidos pelas marcações nas alternativas propostas pelo elaborador, de forma a nortear o trabalho pedagógico das escolas em estudo.

Para o estudo qualitativo dos distratores, após tomar a quantificação de marcações obtidas na fase de coleta de dados e resultados, descritos na seção anterior, foram inferidos e classificados os erros dos alunos.

Após a classificação dos erros em categorias segundo as propostas de Bodin, Radatz e Casey (Seção 6.4), com distribuição dos erros por classes, o próximo objetivo de trabalho era buscar as possíveis causas para os mesmos apoiados nos conhecimentos de Matemática que o aluno deveria utilizar na resolução das situações propostas. Nessa fase, foi utilizada a abordagem de Análise de Conteúdo segundo Bardin (2011) (Capítulo 5). 
Para realizar um trabalho de análise segundo esse método, Bardin (2011) assinala três etapas básicas, que podem ser subdivididas de acordo com as necessidades: préanálise, exploração do material e tratamento dos resultados.

Na primeira fase, o material é organizado, partindo-se da escolha dos documentos, da formulação de hipóteses e objetivos da análise, utilizando-se a leitura "flutuante". Escolhidos os documentos, delimita-se o corpus, que é o campo específico sobre o qual a atenção vai ser fixada.

No caso deste estudo, a escolha do documento já foi apontada anteriormente, a prova de primeira fase da OBMEP 2014, nível 2. A hipótese de estudo, ou questionamento de estudo, é se o instrumento pode ser utilizado como subsídio de uma prática de avaliação para aprendizagem a partir da análise dos distratores de cada item, ou seja, se na construção de cada item o elaborador contribui para a investigação de habilidades ou de conteúdos que precisam ser melhor trabalhados pelo professor em sala de aula.

Entre os objetivos da análise temos:

- investigar em que medida os itens das provas da OBMEP, nível 2, aplicadas no ano 2014 respeitam as recomendações da técnica denominada Engenharia Construção de Itens para uma avaliação de larga escala;

- categorizar os erros cometidos pelo grupo de alunos que respondeu às provas da OBMEP nas escolas pesquisadas;

- investigar em que medida a avaliação está coerente com o propósito estabelecido na matriz de referência e com os objetivos da OBMEP.

O corpus de estudo foram os itens e seus distratores. A fase de exploração do material envolve um estudo do corpus, com procedimentos de unitarização e categorização, onde cada item foi trabalhado individualmente de acordo com os dados quantitativos obtidos pela TCT e a Análise de Conteúdo juntamente com a análise de erros.

De acordo com essa proposta, realizou-se um estudo interpretativo, já que buscouse compreender como os conceitos são utilizados pelos alunos, e, por meio de suas marcações, desvelar o processo escolhido para realizá-lo. Por isso, recorreu-se à Análise de Conteúdo, por ser um procedimento de análise interpretativa que busca o sentido de um texto confrontando duas personagens: o elaborador e o aluno.

Já na fase de tratamento dos resultados, foi realizada a descrição dos itens, que foi feita por meio da apresentação de tabelas e gráficos com indicação das distribuições dos índices relevantes para a TCT nas pesquisas de cunho quantitativo.

Foi realizado o levantamento de possíveis tipo de erro pressupostos nos distratores, inferindo-se e interpretando-se sua natureza. Nessa etapa, a metodologia de construção 
de itens foi retomada para se fazer uma análise detalhada dos textos-base, enunciado e da elaboração de distratores, verificando se há elementos que induzam os estudantes a errar o item. Essa análise foi embasada também na verificação da proposta de solução (Anexo C) dos itens segundo a banca elaboradora do certame, na qual pode se inferir as habilidades necessárias para a correta resolução do item.

Realizar inferências foi o ponto forte para que fossem levantadas hipóteses e estabelecer conexões entre as informações encontradas. Semelhante a isso, na medida em que o professor se propõe a observar e a ouvir o que o aluno faz ao resolver um problema, ele pode realizar "inferências" em sala de aula sobre como o aluno pensou, quais são suas dificuldades, para, então, tomar decisões referentes à sua prática pedagógica.

Ao final dessas etapas, decidiu-se ainda retomar alguns itens e refazer a aplicação dos mesmos para alunos que realizaram o certame anteriormente, mas com o intuito de coletar as resoluções, a produção escrita dos alunos, já que no primeiro momento os instrumentos de análise de dados foram as folhas de respostas contendo apenas as suas marcações. Assim, a pesquisadora retornou a três das cinco escolas em questão e reaplicou os itens 3, 4, 5, 10, 14 e 17, conforme a atividade (Apêndice C), para sanar dúvidas quanto à marcação em algumas alternativas, com objetivo de verificar a plausibilidade dos mesmos. A escolha dos itens poderia ser mais ampla, pois muitos itens apresentaram alternativas sem que a pesquisadora inferisse formas de erros associadas, buscou-se os itens com alguns atrativos na formação, mas que apresentassem valores muito discrepantes dos processos de solução.

Como esta confirmação foi realizada no ano de 2015, apenas 280 listas de exercícios foram aplicadas. Todos os participantes foram informados da intenção do estudo. No geral, apenas as operações eram utilizadas como rascunho. Mesmo não possuindo justificativas bem formalizadas, a Análise do Conteúdo expresso nas resoluções dos alunos possibilitou confirmar algumas possíveis justificativas para o uso do distrator.

Analisar a produção escrita de alunos em questões de Matemática contribui, entre outras coisas, para que o professor busque entender as respostas dadas e o porquê das estratégias escolhidas. Com essa atitude investigativa, o professor pode (re)conhecer que conhecimentos os alunos já possuem e quais ainda estão em construção. 



\section{Análise de Resultados}

\subsection{Análise Geral do Instrumento}

O instrumento analisado encontra-se no Anexo B deste trabalho, e os itens serão investigados com relação à amostra em questão, não objetivando uma generalização de todos os instrumentos da OBMEP, nem deste instrumento em particular aplicado em todo o território nacional, mas no universo de 1.658 alunos e suas respectivas escolas.

A amostra não é aleatória, mas de conveniência, e muito pequena para ser representativa do universo. De acordo com a Tabela 4, o público alvo do estudo não chega a 0,1\% do total de respondentes neste certame. Apesar disso, algumas inferências acerca do comportamento da prova como um todo serão feitas, com as devidas ressalvas.

Em relação à verificação do respeito aos pressupostos da Engenharia de Itens (Capítulo 4), tem-se um resultado descritivo muito relevante, podendo ser utilizado como fundamentação para estruturação de um exame que contribua para uma seleção criteriosa e, ainda, para uma avaliação que seja coloca a serviço das aprendizagens dos estudantes.

No que diz respeito à prática pedagógica, também serão feitas inferências sobre os erros dos estudantes de forma a embasar o uso desse instrumento como referência aos docentes, nas referidas instituições. O estudo serve também como um alerta da relevância de construção de itens bem elaborados para a prática docente em Matemática no nível da sala de aula.

\subsection{Análise Geral da OBMEP-2014, nível 2, primeira fase}

\subsubsection{Matriz de Referência}

Após pesquisa nos meios virtuais, não foi encontrada uma matriz de referência para construção dos 20 itens que compõem a primeira fase da prova da OBMEP. Realizou-se um contato com os responsáveis pela elaboração do certame, que divulgaram por meio de resposta (Anexo D) a questionário de entrevista (Apêndice D), que não há um documento formalizado que aponte uma matriz de referência para elaboração das provas da OBMEP, mas respeitam-se as habilidades e competências por ano/série apresentadas nos PCN.

A metodologia de trabalho do Comitê de Provas da OBMEP é bastante diferente de outras avaliações em larga escala realizadas no Brasil. Em uma visão macro, a OBMEP segue rigorosamente os Parâmetros Curriculares Nacionais, segundo a seguinte divisão: (...) 


\begin{abstract}
Mais especificamente, no que se refere aos conteúdos específicos são consultados os Guias Curriculares dos Estados Brasileiros, atentando para não levar em consideração as diferenças regionais, mas sim o corpo de conhecimentos adequados ao exercício consciente da cidadania, correspondentes a cada faixa etária. Em outras palavras, os conhecimentos avaliados nas provas da OBMEP são os mesmos que constam nos livros didáticos aprovados pelo PNLD; entretanto as questões das provas intencionalmente não são livrescas, exigindo criatividade e inovação, com ênfase no raciocínio e na capacidade de entender e tratar situações, e não na repetição mecânica de procedimentos (Trecho retirado da resposta ao questionamento sobre a existência de uma matriz de referência, pergunta 1).
\end{abstract}

Como não foi apresentada a matriz de referência, ao analisar os itens individualmente, para se inferir as habilidades necessárias para a solução, buscou-se apoio nas habilidades e descritores sugeridas em outros certames e nos PCN. Entre os certames escolhidos, incluem-se aqueles que contemplam conceitos matemáticos em sua elaboração, tais como o Enem e a Prova Brasil, apresentados em (RABELO, 2013).

\title{
8.2.2 Análise global dos itens
}

Todos os itens são inéditos. O tempo previsto para realização da avaliação contempla os 4 minutos geralmente sugeridos em uma prova dessa natureza. Todos os itens atendem o correto uso da norma culta da Língua Portuguesa nos seus diversos quesitos.

Os 20 itens apresentados são de múltipla escolha, para os quais os comandos apresentam uma pergunta direta e, indiscutivelmente, com apenas uma única alternativa correta. Os enunciados não apresentam termos que expressam negação, apresentam um único problema a ser solucionado, não apresentando falha técnica.

Há quatro itens convencionais: 3, 9, 13 e 18. Os demais apresentam texto-base contextualizado. O item 4 apresentou uma exemplificação do processo de solução.

Os textos-base são curtos, integrais e adequados à linguagem dos respondentes. A adequação ao nível dos respondentes será discutida na análise individual dos itens, a ser apresentada no Capítulo 8.3.

Os dados apresentados no texto-base tem razoabilidade e, apenas no item 10, há um dado expresso desnecessário à resolução, os 32,5 litros. Quanto à clareza, infere-se que os itens 10 e 20 possuem textos que não são muito claros para os respondentes.

Os nomes utilizados não se referem a pessoas públicas, nem são jocosos.

\subsubsection{As alternativas}

Na sua maioria, as alternativas são organizadas na forma trapezoidal, a exceção dos itens 6 e 9, que não respeitam essa formatação. Todos as alternativas atendem ao 
correto uso da norma culta da Língua Portuguesa nos seus diversos quesitos, no entanto não apresentam o ponto final nas respostas não numéricas, ou seja não completam adequadamente o comando.

As alternativas apresentam, na sua maioria, estrutura semelhante, exceto nos itens 9, 12, 17 e 18, que não cumprem esta sugestão de elaboração. Há a presença marcante de uso de numeração consecutiva nas alternativas e uso de respostas numéricas na ordem crescente.

Quanto à plausibilidade dos distratores e à presença de fatores de atração, haverá comentários a respeito na análise individual dos itens.

Mas de uma forma geral, foi apontado que os distratores não são construídos com base na Engenharia de Itens, conforme depreende-se da resposta dada pelo coordenador a uma das questões do questionário encaminhado:

\begin{abstract}
A metodologia utilizada na OBMEP é diferente da do ENEM ou de outros testes TRI. Intencionalmente não são colocados distratores nas questões de múltipla escolha da primeira fase. O comitê de provas é atento para evitar distratores, exceto em ocasiões muito raras e especiais. Evita-se, a todo custo, canalizar o aluno a respostas que não sejam as corretas ou que sejam atraídos por interpretações não presentes nos enunciados (Trecho retirado da resposta ao questionamento sobre a construção de distratores, pergunta 6).
\end{abstract}

Esta resposta sugere que a equipe de elaboradores da OBMEP pode estar entendendo o conceito de distrator como "peguinha", e não o sentido apresentado por Rabelo (2013) na Seção 4.7 deste trabalho. A ideia de canalizar à respostas incorretas não está vinculada à plausibilidade na construção dos distratores.

Quanto ao balanceamento dos itens, de acordo com o gabarito oficial apresentado na solução da prova (Anexo C) e na Tabela 12, a distribuição de respostas por alternativa foi bem equilibrada.

\title{
8.2.4 Análise quantitativa - TCT
}

As tabelas a seguir, obtidas na análise pela TCT, apresentam um resumo quantitativo da amostra.

A Tabela 8 apresenta o número de candidatos, da amostra, que realizaram o certame distribuídos de acordo com o escore obtido por cada um. Associado a estes também o percentual de candidatos em cada faixa e a frequência absoluta acumulada. Esta organização possibilita a visualização dos $27 \%$ dos candidatos que obtiveram as maiores e as menores notas, respectivamente. 
Tabela 8 - Análise de escore bruto dos candidatos

\begin{tabular}{cccc}
\hline $\begin{array}{c}\text { Escore } \\
\text { Bruto }\end{array}$ & $\begin{array}{c}\text { Número de } \\
\text { Candidatos }\end{array}$ & $\begin{array}{c}\text { Frequência } \\
\text { Relativa }\end{array}$ & $\begin{array}{c}\text { Frequência } \\
\text { acumulada }\end{array}$ \\
\hline 20 & 0 & 0,0000 & 0,0000 \\
19 & 1 & 0,0006 & 0,0006 \\
18 & 0 & 0,0000 & 0,0006 \\
17 & 3 & 0,0018 & 0,0024 \\
16 & 3 & 0,0018 & 0,0042 \\
15 & 7 & 0,0042 & 0,0084 \\
\hline 14 & 8 & 0,0048 & 0,0132 \\
13 & 7 & 0,0042 & 0,0174 \\
\hline 12 & 7 & 0,0042 & 0,0217 \\
11 & 11 & 0,0066 & 0,0283 \\
\hline 10 & 9 & 0,0054 & 0,0337 \\
\hline & 14 & 0,0084 & 0,0422 \\
\hline 8 & 226 & 0,0157 & 0,0579 \\
\hline 7 & 112 & 0,0676 & 0,1254 \\
\hline 6 & 224 & 0,1351 & 0,2605 \\
\hline 5 & 318 & 0,1918 & 0,4523 \\
\hline 4 & 361 & 0,2177 & 0,6700 \\
\hline 3 & 278 & 0,1677 & 0,8377 \\
\hline 2 & 198 & 0,1194 & 0,9571 \\
\hline 1 & 67 & 0,0404 & 0,9975 \\
\hline 0 & 4 & 0,0024 & 1,0000 \\
\hline
\end{tabular}

Percebe-se que os $27 \%$ que obtiveram maiores notas $\left(P_{S U P}\right)$ obtiveram um escore de 5 ou mais no certame. Enquanto que os $27 \%$ com menores notas $\left(P_{I N F}\right)$ obtiveram escores menores que 4.

Tabela 9 - Análise Geral da Prova da OBMEP-2014 a partir da TCT na amostra

\begin{tabular}{cccccc}
\hline Item & $D$ & $I_{D}$ & $r_{b}$ & $P_{S U P}$ & $P_{I N T}$ \\
\hline 1 & 0,463 & 0,105 & 0,416 & 0,285 & 0,391 \\
2 & 0,214 & 0,092 & 0,411 & 0,102 & 0,195 \\
3 & 0,234 & 0,147 & 0,506 & 0,102 & 0,249 \\
4 & 0,235 & 0,117 & 0,456 & 0,124 & 0,241 \\
5 & 0,179 & 0,071 & 0,410 & 0,099 & 0,169 \\
6 & 0,270 & 0,190 & 0,547 & 0,097 & 0,287 \\
7 & 0,415 & 0,065 & 0,360 & 0,269 & 0,333 \\
8 & 0,347 & 0,101 & 0,418 & 0,207 & 0,308 \\
9 & 0,152 & 0,090 & 0,465 & 0,073 & 0,163 \\
10 & 0,185 & 0,117 & 0,311 & 0,066 & 0,183 \\
11 & 0,197 & 0,142 & 0,479 & 0,068 & 0,209 \\
12 & 0,171 & 0,108 & 0,477 & 0,073 & 0,181 \\
13 & 0,174 & 0,105 & 0,484 & 0,079 & 0,184 \\
14 & 0,162 & 0,067 & 0,451 & 0,091 & 0,159 \\
15 & 0,297 & 0,088 & 0,406 & 0,176 & 0,264 \\
16 & 0,201 & 0,040 & 0,261 & 0,119 & 0,159 \\
17 & 0,106 & 0,037 & 0,293 & 0,060 & 0,097 \\
18 & 0,124 & 0,075 & 0,291 & 0,049 & 0,124 \\
19 & 0,228 & 0,081 & 0,322 & 0,124 & 0,205 \\
20 & 0,180 & 0,035 & 0,206 & 0,108 & 0,143 \\
\hline
\end{tabular}

A Tabela 9 mostra que o item mais fácil da prova tem índice de dificuldade de $46 \%$, que trata-se de um item de dificuldade mediana. De acordo com a classificação recomendada na literatura, a prova apresentou a seguinte distribuição: nenhum item fácil; três itens medianos e dezesseis itens difíceis. Em geral, segundo Rabelo (2013), o texto deveria apresentar cerca de 30\% de itens fáceis, $40 \%$ de itens medianos e $30 \%$ de itens difíceis. A Tabela 10 mostra a distribuição dos itens de acordo com a dificuldade. 
Tabela 10 - Distribuição dos itens em relação ao parâmetro dificuldade, segundo a TCT.

\begin{tabular}{lccc}
\hline Classificação & $\begin{array}{c}\text { Intervalo de } \\
\text { dificuldade } D\end{array}$ & Itens & $\begin{array}{c}\text { Percentual de } \\
\text { itens na prova }\end{array}$ \\
\hline Muito Fácil & $D \geq 0,9$ & & $0 \%$ \\
Fácil & $0,7 \leq D<0,9$ & & $0 \%$ \\
Moderado & $0,3 \leq D<0,7$ & 1,7 e 8 & $15 \%$ \\
Difícil & $0,1 \leq D<0,3$ & 2 a 6 e 9 a 20 & $85 \%$ \\
Muito Difícil & $D<0,1$ & & $0,00 \%$ \\
\hline
\end{tabular}

Quanto à discriminação $I_{D}$ (Tabela 9), de acordo com o poder de discriminação dos itens, todos os itens deveriam ser descartados, pois apresentam índice de discriminação $I_{D}<0,2$. Um resultado alarmante, mas justificável devido a proximidade de faixa de escore entre os $27 \%$ candidatos com maiores notas e os $27 \%$ dos candidatos com menores notas, onde a distancia entre escore de 2 pontos de acordo com a Tabela 8. A Tabela 11 apresenta a distribuição dos itens de acordo com o índice de discriminação via TCT.

Tabela 11 - Distribuição dos itens em relação a discriminação, pela TCT.

\begin{tabular}{lccc}
\hline Classificação & $\begin{array}{c}\text { Intervalo de } \\
\text { discriminação } I_{D}\end{array}$ & Itens & $\begin{array}{c}\text { Percentual de } \\
\text { itens na prova }\end{array}$ \\
\hline Item deficiente & até 0,2 & 1 ao 20 & $100 \%$ \\
Item marginal & $0,2 \leq I_{D}<0,3$ & & $0 \%$ \\
$\begin{array}{l}\text { Item bom, mas sujeito a aprimora- } \\
\text { mento }\end{array}$ & $0,3 \leq I_{D}<0,4$ & $0 \%$ \\
Item bom & $I_{D} \geq 0,4$ & $0 \%$ \\
\hline
\end{tabular}

Em compensação, o coeficiente bisserial do item $r_{b}$ (Tabela 9), que se relaciona com a marcação do item certo, demonstra que quatorze itens tem características de itens bons quanto à discriminação, três itens estão sujeitos a aprimoramento e três marginais, sujeitos a reelaboração.

De acordo com a Tabela 12, percebe-se 7 itens com coeficientes bisseriais positivos em alternativas errôneas, o que será analisado na seção de estudo individual dos itens, para justificar a presença ou não de fatores de atração para as alternativas erradas de indivíduos com escore mais alto, que também pode ser verificado na Tabela 13, que evidencia presença de proporções elevadas de marcação em alternativas incorretas. 
Tabela 12 - Coeficientes bisseriais das alternativas de cada item.

\begin{tabular}{cccccccc}
\hline Item & Gabarito & $r_{b}(A)$ & $r_{b}(B)$ & $r_{b}(C)$ & $r_{b}(D)$ & $r_{b}(E)$ & $r_{b}($ Branco $)$ \\
\hline 1 & $\mathrm{~B}$ & $-0,268$ & $\mathbf{0 , 4 1 6}$ & $-0,148$ & $-0,179$ & $-0,159$ & $-0,132$ \\
2 & $\mathrm{D}$ & $-0,126$ & $-0,146$ & $-0,096$ & $\mathbf{0 , 4 1 1}$ & $-0,084$ & $-0,107$ \\
3 & $\mathrm{D}$ & $-0,154$ & $-0,174$ & $-0,086$ & $\mathbf{0 , 5 0 6}$ & $-0,144$ & $-0,138$ \\
4 & $\mathrm{~B}$ & $-0,100$ & $\mathbf{0 , 4 5 6}$ & $-0,141$ & $-0,162$ & $-0,148$ & $-0,213$ \\
5 & $\mathrm{~A}$ & $\mathbf{0 , 4 1 0}$ & $-0,085$ & $-0,022$ & $-0,117$ & $-0,213$ & $-0,075$ \\
6 & $\mathrm{D}$ & $-0,231$ & $-0,126$ & $-0,149$ & $\mathbf{0 , 5 4 7}$ & $-0,183$ & $-0,039$ \\
7 & $\mathrm{~A}$ & $\mathbf{0 , 3 6 0}$ & $-0,136$ & $-0,171$ & $-0,124$ & $-0,169$ & $-0,263$ \\
8 & $\mathrm{~A}$ & $\mathbf{0 , 4 1 8}$ & $-0,142$ & $-0,185$ & $-0,149$ & $-0,142$ & $-0,192$ \\
9 & $\mathrm{E}$ & $-0,112$ & $-0,162$ & $\mathbf{0 , 0 3 3}$ & $-0,143$ & $\mathbf{0 , 4 6 5}$ & $-0,246$ \\
10 & $\mathrm{~B}$ & $-0,139$ & $\mathbf{0 , 3 1 1}$ & $-0,095$ & $\mathbf{0 , 0 3 7}$ & $-0,132$ & $-0,120$ \\
11 & $\mathrm{C}$ & $-0,109$ & $-0,120$ & $\mathbf{0 , 4 7 9}$ & $-0,076$ & $-0,169$ & $-0,240$ \\
12 & $\mathrm{D}$ & $-0,202$ & $-0,093$ & $-0,091$ & $\mathbf{0 , 4 7 7}$ & $\mathbf{0 , 0 1 8}$ & $-0,070$ \\
13 & $\mathrm{E}$ & $-0,067$ & $-0,029$ & $-0,193$ & $-0,122$ & $\mathbf{0 , 4 8 4}$ & $-0,202$ \\
14 & $\mathrm{C}$ & $-0,185$ & $-0,072$ & $\mathbf{0 , 4 5 1}$ & $-0,141$ & $\mathbf{0 , 0 2 3}$ & $-0,245$ \\
15 & $\mathrm{C}$ & $-0,169$ & $-0,113$ & $\mathbf{0 , 4 0 6}$ & $-0,105$ & $-0,145$ & $-0,266$ \\
16 & $\mathrm{C}$ & $-0,019$ & $-0,028$ & $\mathbf{0 , 2 6 1}$ & $-0,088$ & $-0,135$ & $-0,103$ \\
17 & $\mathrm{C}$ & $-0,125$ & $-0,051$ & $\mathbf{0 , 2 9 3}$ & $\mathbf{0 , 0 8 0}$ & $-0,044$ & $-0,112$ \\
18 & $\mathrm{E}$ & $-0,149$ & $\mathbf{0 , 0 0 4}$ & $\mathbf{0 , 0 2 3}$ & $-0,069$ & $\mathbf{0 , 2 9 1}$ & $-0,106$ \\
19 & $\mathrm{~B}$ & $-0,086$ & $\mathbf{0 , 3 2 2}$ & $-0,090$ & $-0,078$ & $-0,115$ & $-0,218$ \\
20 & $\mathrm{D}$ & $-0,138$ & $\mathbf{0 , 0 0 6}$ & $\mathbf{0 , 0 0 5}$ & $\mathbf{0 , 2 0 6}$ & $-0,051$ & $-0,220$ \\
\hline
\end{tabular}

Tabela 13 - Porcentagem de marcação nas alternativas de cada item

\begin{tabular}{cccccccc}
\hline Item & Gabarito & $p(A)$ & $p(B)$ & $p(C)$ & $p(D)$ & $p(E)$ & $p($ Branco $)$ \\
\hline 1 & $\mathrm{~B}$ & 0,203 & $\mathbf{0 , 4 6 3}$ & 0,166 & 0,107 & 0,058 & 0,000 \\
2 & $\mathrm{D}$ & 0,095 & 0,185 & 0,253 & $\mathbf{0 , 2 1 4}$ & 0,245 & 0,008 \\
3 & $\mathrm{D}$ & 0,174 & 0,282 & 0,154 & $\mathbf{0 , 2 3 4}$ & 0,147 & 0,009 \\
4 & $\mathrm{~B}$ & 0,265 & $\mathbf{0 , 2 3 5}$ & 0,280 & 0,150 & 0,065 & 0,005 \\
5 & $\mathrm{~A}$ & $\mathbf{0 , 1 7 9}$ & 0,162 & 0,340 & 0,179 & 0,138 & 0,003 \\
6 & $\mathrm{D}$ & 0,207 & 0,192 & 0,202 & $\mathbf{0 , 2 7 0}$ & 0,127 & 0,002 \\
7 & $\mathrm{~A}$ & $\mathbf{0 , 4 1 5}$ & 0,094 & 0,145 & 0,098 & 0,242 & 0,006 \\
8 & $\mathrm{~A}$ & $\mathbf{0 , 3 4 7}$ & 0,195 & 0,218 & 0,128 & 0,103 & 0,008 \\
9 & $\mathrm{E}$ & 0,224 & 0,200 & 0,240 & 0,179 & $\mathbf{0 , 1 5 2}$ & 0,005 \\
10 & $\mathrm{~B}$ & 0,104 & $\mathbf{0 , 1 8 5}$ & 0,251 & 0,256 & 0,195 & 0,008 \\
11 & $\mathrm{C}$ & 0,249 & 0,255 & $\mathbf{0 , 1 9 7}$ & 0,157 & 0,134 & 0,008 \\
12 & $\mathrm{D}$ & 0,254 & 0,264 & 0,229 & $\mathbf{0 , 1 7 1}$ & 0,075 & 0,007 \\
13 & $\mathrm{E}$ & 0,160 & 0,197 & 0,259 & 0,204 & $\mathbf{0 , 1 7 4}$ & 0,006 \\
14 & $\mathrm{C}$ & 0,187 & 0,329 & $\mathbf{0 , 1 6 2}$ & 0,178 & 0,141 & 0,004 \\
15 & $\mathrm{C}$ & 0,203 & 0,151 & $\mathbf{0 , 2 9 7}$ & 0,186 & 0,159 & 0,004 \\
16 & $\mathrm{C}$ & 0,250 & 0,189 & $\mathbf{0 , 2 0 1}$ & 0,159 & 0,198 & 0,003 \\
17 & $\mathrm{C}$ & 0,467 & 0,095 & $\mathbf{0 , 1 0 6}$ & 0,142 & 0,186 & 0,005 \\
18 & $\mathrm{E}$ & 0,230 & 0,235 & 0,200 & 0,203 & $\mathbf{0 , 1 2 4}$ & 0,009 \\
19 & $\mathrm{~B}$ & 0,142 & $\mathbf{0 , 2 2 8}$ & 0,289 & 0,242 & 0,092 & 0,006 \\
20 & $\mathrm{D}$ & 0,230 & 0,218 & 0,194 & $\mathbf{0 , 1 8 0}$ & 0,175 & 0,004 \\
\hline
\end{tabular}

Esse fato, quando ocorre, segundo Rodrigues, não significa que um item tem um problema de elaboração, mas pode indicar uma falta coletiva de habilidades diante ao objetivo de aprendizagem verificado.

Assim, é importante que, em conjunto com a AGI, seja realizada uma análise pedagógica desses itens. Essas análises poderão dar indicativos do processo mental utilizado para a solução da questão, associando-se o escore total e as respostas dos distratores (RODRIGUES, 2006).

Assim se faz necessário realizar uma análise mais detalhada de cada item, utilizando dados da TCT, da AGI por item, as recomendações constantes da engenharia de itens, a Análise de Conteúdo e do erro, para realizar um retrato do item frente ao grupo 
pesquisado, o que pode contribuir para os elaboradores na confecção de novos instrumentos da OBMEP no futuro. 


\subsection{Análise Individualizada dos Itens da OBMEP}

A seguir serão apresentadas uma análise individualizada dos itens presentes na prova de primeira fase da OBMEP 2014, nível 2, de acordo com a investigação do grupo pesquisado, embasando-se na Análise de Conteúdo, na Análise do Erro, dos pressupostos da Engenharia de Construção de Itens e pela TCT.

\subsubsection{Item 1}

Paula numerou todas as casas do tabuleiro quadrado abaixo, da esquerda para a direita e de cima para baixo, começando com o número 1. A casa central recebeu o número 5. Se ela fizer o mesmo com outro tabuleiro quadrado com 49 casas, qual número será escrito em sua casa central?
A) 23
B) 25
C) 27
D) 29
E) 31

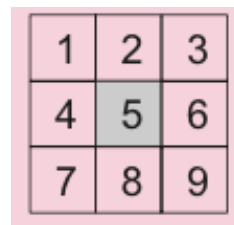

Análise do Item 1

\begin{tabular}{cccccc}
\hline Questão & Gabarito & Dificuldade & Índice D & Bisserial \\
Q1 & B & 0,463 & 0,105 & 0,416 \\
Acerto: & $27 \%$ maiores notas & Acerto: $27 \%$ menores notas \\
\multicolumn{5}{c}{0.285} \\
$r_{b}(A)$ & $r_{b}(B)$ & $r_{b}(C)$ & $r_{b}(D)$ & $r_{b}(E)$ & $r_{b}()$ \\
$-0,268$ & $\mathbf{0 , 4 1 6}$ & $-0,148$ & $-0,179$ & -0.159 & $-0,132$ \\
$p(A)$ & $p(B)$ & $p(C)$ & $p(D)$ & $p(E)$ & $p()$ \\
0,203 & $\mathbf{0 , 4 6 3}$ & 0,166 & 0,107 & 0,058 & 0,000 \\
\hline
\end{tabular}

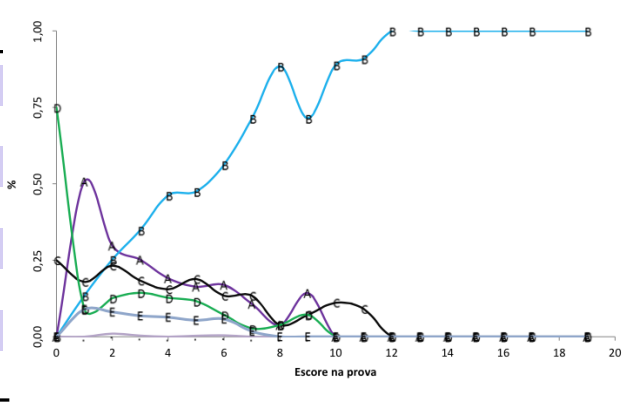

A habilidade necessária para resolver a situação proposta é a de ordenar os números naturais e escolher o termo central da sequência de números consecutivos. Pode ser interpretada, com o enfoque do tratamento de informação, como a mediana. Desta forma podem ser verificadas as habilidades relacionadas a coleta, a organização e a descrição de dados, ou seja, calcular medidas de tendência central.

Na solução apresentada pelo elaborador (Anexo C), há também, a possibilidade de interpretação e resolução da situação-problema utilizando uma expressão algébrica.

A alternativa correta discriminou bem, seu coeficiente bisserial foi de 0,416, e a AGI também denota que há uma concentração de itens errôneos entre os estudantes de proficiência menor.

No que se refere aos distratores há problemas na construção do item, pois a alternativa E teve uma marcação muito baixa. Infere-se que na escolha dos distratores não 
houve construção plausível, apenas o ordenamento de números ímpares a partir do 23.

Após realizar várias tentativas de erro, inferiu-se um erro onde o aluno construiu tabelas $3 \times 3$, e escreveu os números até 49, na mesma ordenação do exemplo. Onde apareceram 5 tabelas completas, e ao relacionar desta forma o número 23 apareceu no quadrado central da terceira tabela. Um erro relacionado a: lógica e raciocínio, segundo Bodin (1997), aplicação de regras irrelevantes, segundo Radatz (1979) e, com exceção ao erro relacionado a formulação da questão, todos os demais de acordo com Casey (CLEMENTS, 1980 apud CURY, 2007).

A alternativa E deveria ser descartada de acordo com os apontamento da Engenharia de Itens (Capítulo 4) Como esta questão não apresenta muitos obstáculos em sua resolução, a situação-problema deveria ser ampliada, pois há a dificuldade para elaborar 4 distratores plausíveis, contribuindo para a análise pedagógica dos possíveis erros e também para um instrumento de seleção com mais qualidade.

Todos os fatos acima podem ter contribuído para o nível de dificuldade - mediano, como a marcação nas últimas alternativas foram baixas, a concentração porcentual na alternativa correta aumenta proporcionalmente elevando a facilidade do item. 


\subsubsection{Item 2}

Ana Maria apertou as teclas de sua calculadora 109010 0 e o resultado 2014 apareceu no visor. Em seguida, ela limpou o visor e fez aparecer novamente 2014 com uma multiplicação de dois números naturais, mas, desta vez, apertando seis teclas em vez de sete. Nesta segunda multiplicação, qual foi o maior algarismo cuja tecla ela apertou?
A) 5
B) 6
C) 7
D) 8
E) 9

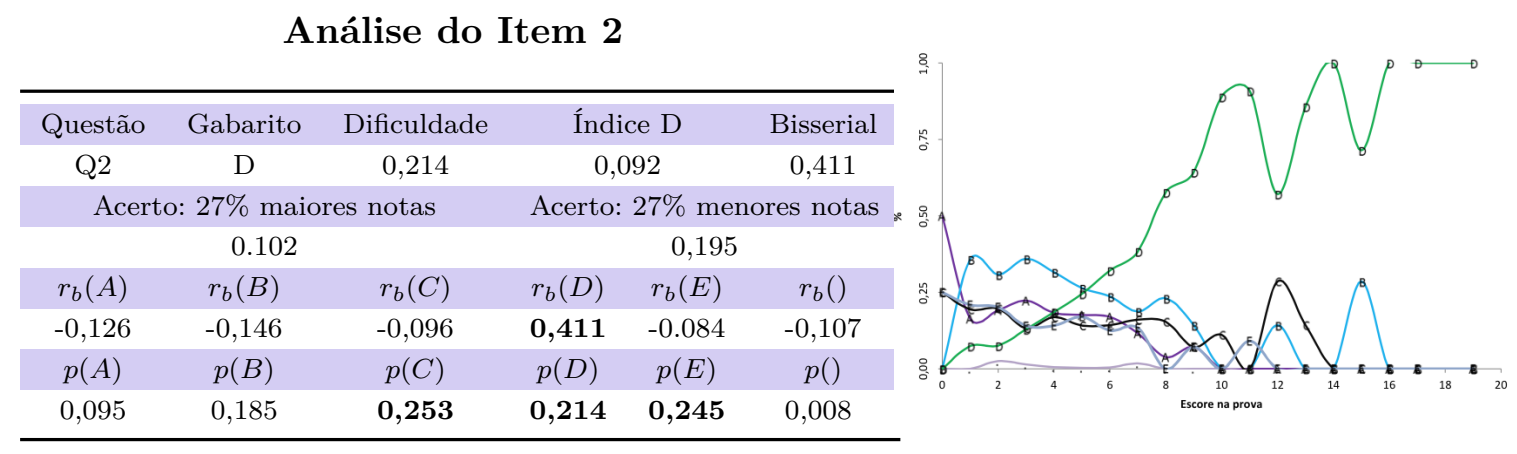

O nível de dificuldade foi de 0,214, caracterizando o item como difícil.

As habilidades exploradas no item são: resolver um problema com números naturais envolvendo diferentes significados das operações, no caso multiplicação; aplicar a decomposição de número natural em fatores primos; empregar o conceito de algarismo e valor absoluto do número.

A alternativa correta discriminou bem, seu coeficiente bisserial foi de 0,411, e a AGI também denota que há uma concentração de itens errôneos entre os estudantes de proficiência menor. No que se refere aos distratores há problemas na construção do item, pois a alternativa A teve uma marcação muito baixa: $9 \%$ dos respondentes a escolheram.

Com relação a interpretação do item, sabe-se que 2014 decomposto em fatores primos pode ser escrita unicamente, a menos da ordem dos fatores, da seguinte forma $2 \times 19 \times 53$. Assim existem somente quatro formas possíveis de se fazer aparecer 2014 na calculadora como uma multiplicação de dois números naturais, onde a última opção corresponde a situação proposta:

Usando sete teclas: $1 \times 2014=$

Usando sete teclas: $2 \times 1007=$ 
Usando sete teclas: $19 \times 106=$

Usando seis teclas: $38 \times 53=$

A partir desta solução apresentada, infere-se que:

- ao marcar a alternativa A, o aluno compreendeu o processo de resolução, conseguiu fatorar o número corretamente, escolheu a opção que era exigida entre as fatorações, mas não aplicou o conceito de valor absoluto do algarismo e escolheu na verdade o número que possui maior valor posicional na multiplicação $38 \times 53=$, que é o número 5. Em uma avaliação formativa na perspectiva de análise de erro, o distrator poderia ser descartado caso a habilidade verificada fosse a fatoração de números primos, este é um exemplo de "peguinha", pois o aluno demonstrou o conhecimento necessário para resolvê-la mas se confundiu por ver um possível resultado na sua resolução, de acordo com a Seção 4.7);

- ao marcar a alternativa $\mathrm{C}$, o aluno também fatorou corretamente, mas se confundiu na escolha da opção correta de número de teclas apertadas e na opção $2 \times 1007$, onde o maior algarismo é o sete. Analogamente pode ter ocorrido na alternativa E, mas neste item ainda tem o atrativo desta fatoração ser o exemplo dado no texto-base. O que justificaria a escolha destes distratores;

- ao marcar B, o estudante também fatorou corretamente, mas não se atentou ao número de teclas para serem acionadas e utilizou a forma $38 \times 53=$, e escolheu o número 8.

Logo as alternativas A e E poderiam ser descartadas, de acordo com Rabelo (2013), ou aconselha-se a reelaboração dos valores apresentados no texto base para diminuir o fator de atração da alternativa E. Assim o item poderia ser reelaborado na perspectiva da Engenharia de itens, o que caracteriza um item com problemas na construção para ser utilizado numa avaliação formativa que utilize análise de erros e em um certame seletivo.

A marcação da alternativa A implica, de acordo com os apontamentos acima, que erro de saber o conceito de algarismo, ver patamares de identificação de erros segundo Bodin (1997), Seção 6.4. E segundo os mecanismos de processamento de informação de Radatz (1979), é um erro devido ao domínio deficiente de conteúdos, fatos e habilidades consideradas como pré-requisito.

Para as alternativas $\mathrm{B}$ e $\mathrm{C}$, podem ser classificados quanto ao erro da seguinte forma: erros de lógica ou de raciocínio, erros devido a associações incorretas ou rigidez de pensamento e manipulação das habilidades, respectivamente segundo Bodin (1997), Radatz (1979) e Casey (CLEMENTS, 1980 apud CURY, 2007). 


\subsubsection{Item 3}

Na figura, os pontos A, B e C estão alinhados. Qual é a soma dos ângulos marcados em cinza?
A) $120^{\circ}$
B) $180^{\circ}$
C) $270^{\circ}$
D) $360^{\circ}$
E) $540^{\circ}$

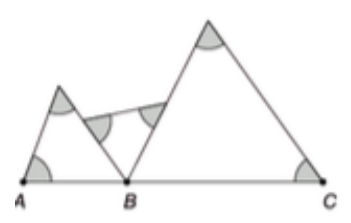

Análise do Item 3

\begin{tabular}{|c|c|c|c|c|c|}
\hline Questão & Gabarito & Dificuldade & \multicolumn{2}{|c|}{ Índice D } & Bisserial \\
\hline Q3 & $\mathrm{D}$ & 0,234 & \multicolumn{2}{|c|}{0,147} & 0,506 \\
\hline \multicolumn{3}{|c|}{ Acerto: $27 \%$ maiores notas } & \multicolumn{3}{|c|}{ Acerto: $27 \%$ menores notas } \\
\hline \multicolumn{3}{|c|}{0,102} & \multicolumn{3}{|c|}{0,249} \\
\hline$r_{b}(A)$ & $r_{b}(B)$ & $r_{b}(C)$ & $r_{b}(D)$ & $r_{b}(E)$ & $r_{b}()$ \\
\hline$-0,154$ & $-0,174$ & $-0,086$ & 0,506 & $-0,144$ & $-0,138$ \\
\hline$p(A)$ & $p(B)$ & $p(C)$ & $p(D)$ & $p(E)$ & $p()$ \\
\hline 0,174 & 0,282 & 0,154 & 0,234 & 0,147 & 0,009 \\
\hline
\end{tabular}

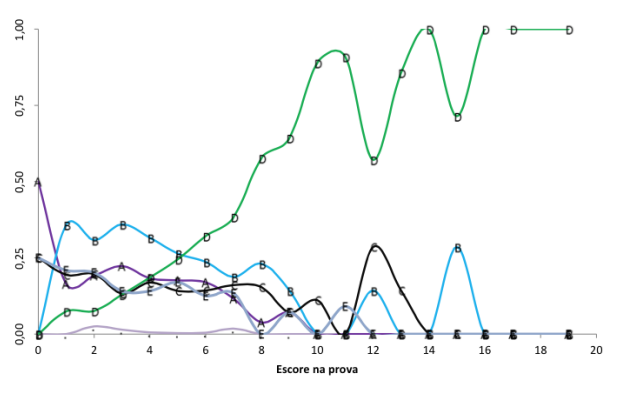

A alternativa correta discriminou bem, seu coeficiente bisserial foi de 0,506, e a AGI também denota que há uma concentração de itens errôneos entre os estudantes de proficiência menor.

Infere-se que as habilidades necessárias a resolução do item são:utilizar conhecimentos geométricos de espaço e forma na seleção de argumentos propostos como solução de problema, resolver problema utilizando a propriedade dos polígonos: soma dos seus ângulos internos e o ângulo externo de triângulos. E no tocante a plausibilidade em construir os distratores:

- em relação a alternativa A, o aluno apenas considerou que os ângulos são de 20 graus, o que não é uma abordagem plausível;

- ao marcar o item B, que o estudante conhecia a propriedade da soma dos ângulos internos de um triângulo, que é $180^{\circ}$, mas não analisou a situação proposta. Erro ligados à utilização adequada ou não dos saberes ou do saber-fazer, erros devido a associações incorretas ou rigidez de pensamento;

- ao marcar a alternativa C, poderia ter assumido erroneamente a característica dos triângulos em estudo, confundindo com a propriedades dos triângulos retângulos, e categorizando-os como triângulos retângulos erroneamente, considerou que os ângulos sobre a hipotenusa somam $90^{\circ}$, e como são três triângulos obteve como total $270^{\circ}$ (ver Figura 12); 


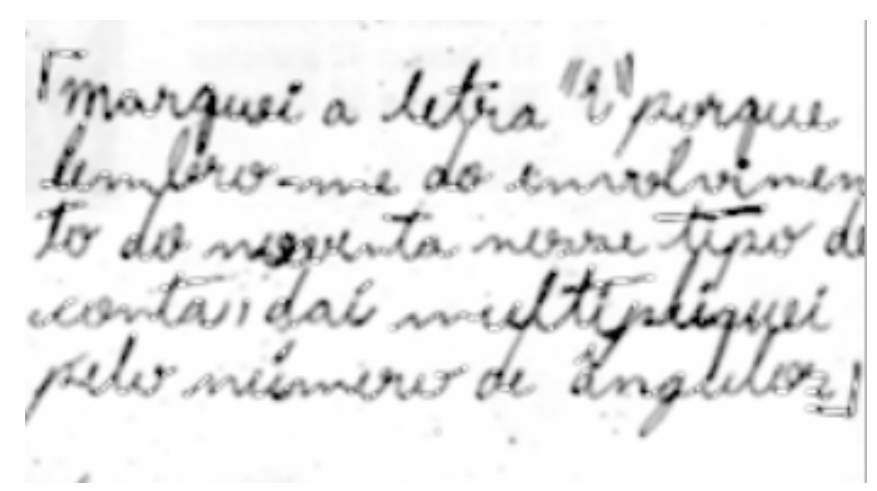

Figura 12 - Solução apresentada pelo aluno E2A18.

- já na alternativa E, poderia ter assumido que três triângulos quaisquer somam $540^{\circ}$, sem observar que nem todos os ângulos estavam destacados.

O nível de dificuldade foi de 0,234 , logo o item foi difícil. Com relação aos distratores, com exceção ao primeiro que poderia ser reelaborado de acordo com a Seção 4.7, todos os outros poderiam ser justificados e analisados no tocante ao erro para reestruturação dos conceitos.

Assim os caminhos errôneos preestabelecidos nos distratores $\mathrm{C}$ e E podem ser classificados assim: erros de saber-fazer, erros ligados à utilização adequada ou não dos saberes ou do saber-fazer, erros devido a associações incorretas ou rigidez de pensamento; erros devido a dificuldade de obter informação espacial; seleção das estratégias requeridas e manipulação das habilidades.

Sugere-se também, de acordo com Rabelo (2013), que haja uma contextualização, para que o aluno mobilize competências e habilidades para sua resolução. 


\subsubsection{Item 4}

A sequência $-6,12,-18,24,-30,36, \ldots$ é obtida a partir dos múltiplos positivos de 6, multiplicando-se os termos nas posições ímpares por -1. Observe na figura que a soma dos dois primeiros termos da sequência é igual a 6 e a soma dos três primeiros termos é igual a -12. Quantos termos consecutivos dessa sequência devemos somar a partir do primeiro, para obter 180 como resultado?
A) 30
B) 60
C) 90
D) 120
E) 180

\section{$-6+12=6$}

$-6+12-18=-12$

$-6+12-18+24=12$

Análise do Item 4

\begin{tabular}{cccccc}
\hline Questão & Gabarito & Dificuldade & Índice D & Bisserial \\
Q4 & B & 0,235 & 0,117 & 0,456 \\
Acerto: & $27 \%$ maiores notas & Acerto: $27 \%$ menores notas \\
\multicolumn{7}{c}{0,241} \\
$r_{b}(A)$ & $r_{b}(B)$ & $r_{b}(C)$ & $r_{b}(D)$ & $r_{b}(E)$ & $r_{b}()$ \\
$-0,100$ & $\mathbf{0 , 4 5 6}$ & $-0,141$ & $-0,162$ & $-0,148$ & $-0,213$ \\
$p(A)$ & $p(B)$ & $p(C)$ & $p(D)$ & $p(E)$ & $p()$ \\
$\mathbf{0 , 2 6 5}$ & $\mathbf{0 , 2 3 5}$ & $\mathbf{0 , 2 8 0}$ & 0,150 & 0,065 & 0,005 \\
\hline
\end{tabular}

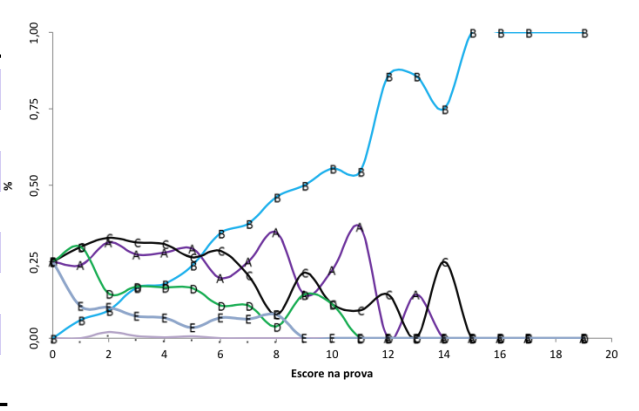

A alternativa correta discriminou bem, seu coeficiente bisserial foi de 0,456, e a AGI também denota que há uma concentração de itens errôneos entre os estudantes de proficiência menor.

No que se refere aos distratores há problemas na construção do item, pois a alternativa E que teve uma marcação muito baixa, embora apresentasse um fator de atração, pois o valor 180 está no comando do item, e sua reelaboração é indicada.

No tocante a plausibilidade em construir os distratores, vê se em relação a solução proposta pelo elaborador:

podemos organizar as somas dos termos da sequência aos pares: $(-6+12)+(-$ $18+24)+(-30+36)+(-42+48)+\ldots$ Observamos que, para cada par de termos consecutivos, arranjados como acima, a soma é 6. Assim, para obter 180 devemos somar os $180 / 6=30$ primeiros pares, ou seja, os $30 \times 2=60$ primeiros termos da sequência (Anexo C).

- que ao escolher a alternativa A, o candidato realizou a adição das parcelas até encontrar o 180, contabilizando 30 parcelas, como na solução do aluno apresentada na Figura 13; 


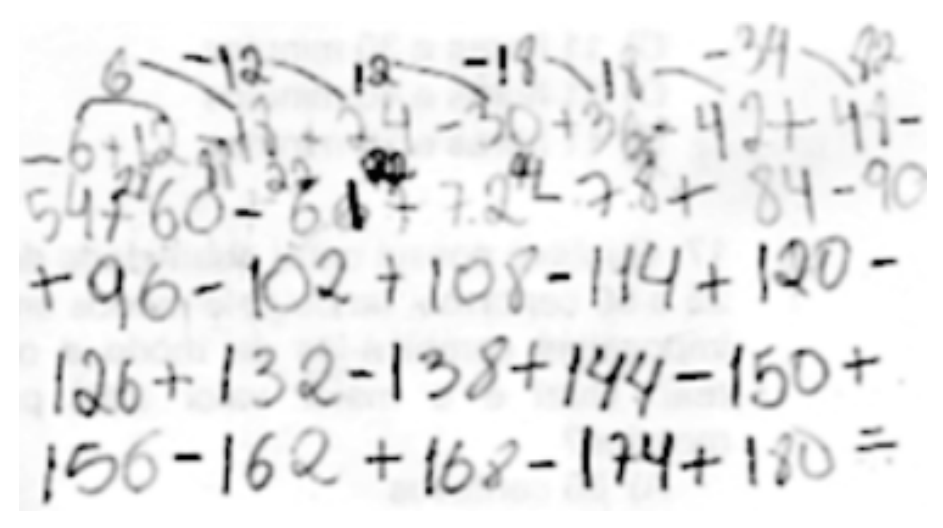

Figura 13 - Solução apresentada pelo aluno E1A11.

- que ao escolher a alternativa C, o aluno até observou que a soma de pares consecutivos deveria ser realizada e erroneamente dividiu 180 por 2 (característico do pareamento) e obteve 90;

- e nada foi inferido ao resultado 120, alternativa D.

Os erros apresentados nos distratores justificados podem ser categorizados assim: na alternativa A - erros ligados à utilização adequada ou não dos saberes ou do saber-fazer e erros de lógica ou de raciocínio; e para a alternativa C - erros de lógica ou de raciocínio e erros devido a aplicações de regras ou estratégias irrelevantes, leitura e compreensão e para a alternativa E erro de formulação da questão, conforme Seção 6.4.

O nível de dificuldade foi de 0,235, logo o item foi difícil, embora a as habilidades necessárias para resolução seriam: identificar padrões numéricos e realizar operações aritméticas com números inteiros. Talvez o exemplo dado na figura e o número desejado de parcelas não tenham contribuído para a interpretação da situação proposta. 


\subsubsection{Item 5}

Os irmãos Luiz e Lúcio compraram um terreno cercado por um muro de 340 metros. Eles construíram um muro interno para dividir o terreno em duas partes. A parte de Luiz ficou cercada por um muro de 260 metros e a de Lúcio, por um muro de 240 metros. Qual é o comprimento do muro interno?
A) $80 \mathrm{~m}$
B) $100 \mathrm{~m}$
C) $160 \mathrm{~m}$
D) $180 \mathrm{~m}$
E) $200 \mathrm{~m}$

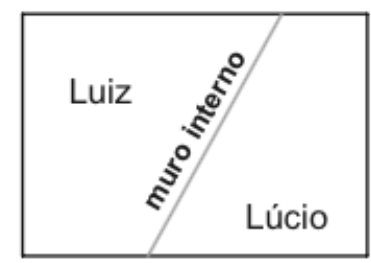

Análise do Item 5

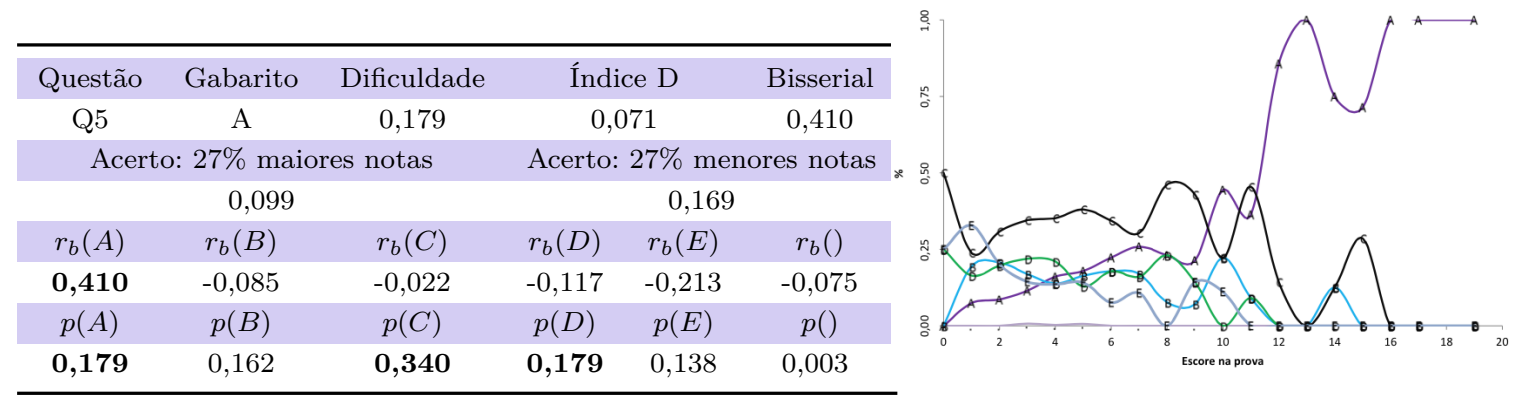

A alternativa correta apresentou o coeficiente bisserial de 0,41, e a AGI denota que há uma concentração de itens errôneos entre os estudantes de proficiência menor, mesmo com o nível de dificuldade de 0,179 houve uma boa discriminação.

As habilidades, inferidas, deste item são: resolver problema envolvendo o cálculo de perímetro de figuras planas, ou resolver situação-problema que envolva conhecimentos geométricos de grandezas e medidas, ou utilizar conhecimentos geométricos de espaço e forma na seleção de argumentos propostos como solução de problemas do cotidiano, ou ainda, resolver situação-problema cuja modelagem envolva conhecimentos algébricos.

No que se refere aos distratores, vê se em relação a solução proposta pelo elaborador:

somando as metragens dos muros de Luiz e de Lúcio, obtemos $240+260$ $=500 \mathrm{~m}$. Neste total estão computados o comprimento do muro original (de $340 \mathrm{~m}$ ) mais duas vezes o comprimento do muro interno. Logo, o comprimento do muro interno é igual a [500 - 340] / $2=80$ metros.

Podemos também resolver algebricamente: como o muro interno pertence ao cercado dos terrenos de Luiz e de Lúcio, se x é a medida do muro interno, temos:

$340+2 \mathrm{x}=240+260$ Portanto $\mathrm{x}=80 \mathrm{~m}$ (Anexo $\mathrm{C})$.

- e levando em consideração os percentuais de marcação acima da alternativa correta, 
infere-se o fator atrativo da alternativa C, pois 160 é o valor encontrado na operação 500 - 340. Traço que caracteriza um "peguinha" de acordo com a Seção 4.7, para estudantes com um escore mais elevado que poderiam estar resolvendo de forma correta e ao encontrar um valor presente nas alternativas, realiza a marcação precipitada. Fato observado AGI, onde aluno com escorre 15 realizou esta marcação, assim é considerado um distrator não plausível devido ao "peguinha";

- a marcação da alternativa B pode ser devida a diferença entre o perímetro total e o muro de Lúcio. O mesmo pode ter ocorrido aos candidatos que marcaram a letra A, que é o gabarito, com relação a diferença entre o muro total e o muro de Luiz;

- a marcação da alternativa D pode ser devida ao cálculo das diferenças entre o muro total e o de Lúcio, igual a 80 metros para o muro interno, e do muro total com o de Luiz, falam 100 metros para o muro interno. Que ao adicionar estes dois valores totaliza-se 180 metros (ver Figuras 14 e 15).

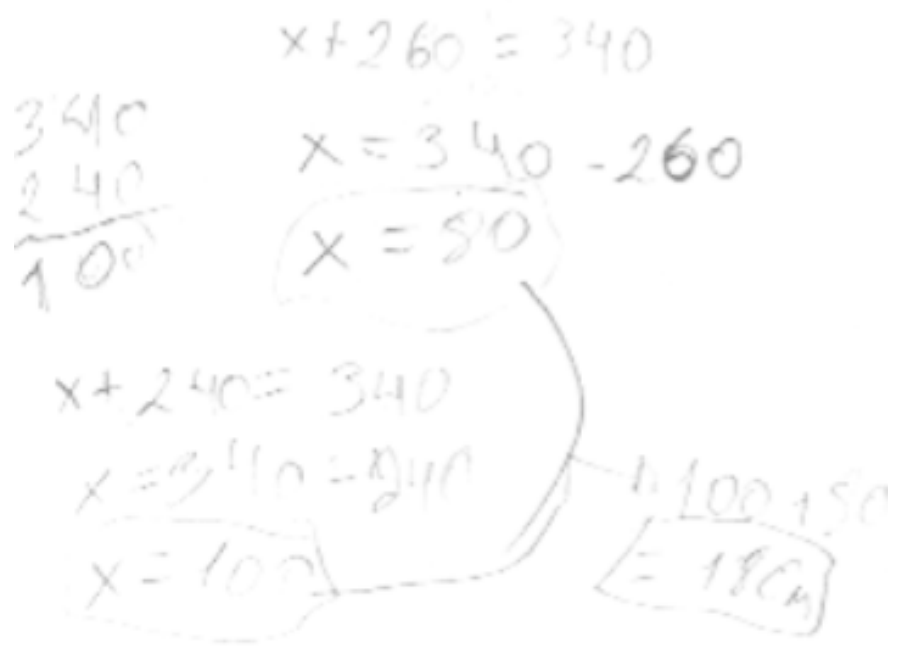

Figura 14 - Solução apresentada pelo aluno E1A15.

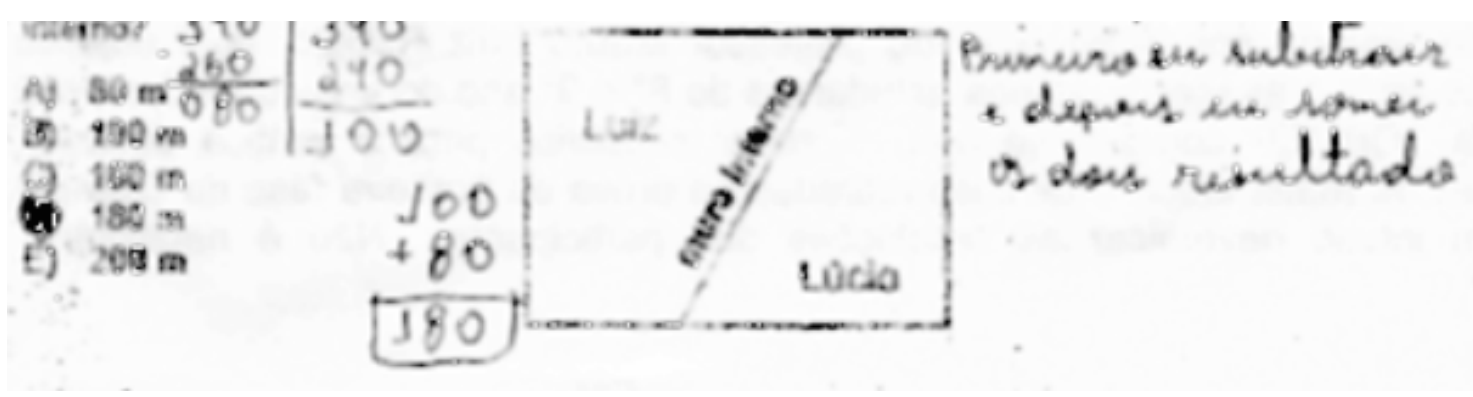

Figura 15 - Solução apresentada pelo aluno E2A11.

- no que se refere a última alternativa nada foi inferido. Embora um aluno tenha apresentado este erro durante a reaplicação do item. Como vemos na Figura 16, é 
um erro que abrange o não entendimento do problema e também de saber realizar a operação de divisão de números naturais.

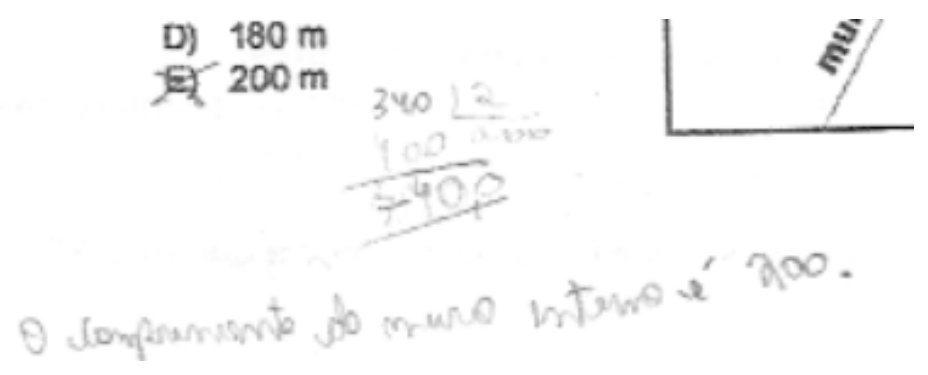

Figura 16 - Solução da questão proposta pelo aluno E1A12.

Assim, para haver maior conformidade com a Engenharia de itens (Capítulo 4), sugere-se aplicar outros valores como dados, para que alunos com baixa proficiência não acertem utilizando erros de interpretação. E a também, sugere se a retirada de alternativas que caracterizem valores encontrados em procedimentos corretos, mas obtidas no meio do percurso de resolução.

Quanto erros em análise nos distratores podem ser classificados assim, para a marcação na alternativa:

$\mathrm{B}$ - erros ligados à utilização adequada ou não dos saberes ou do saber-fazer, erros de lógica ou de raciocínio, erro devido a dificuldade de obter informação espacial, erros devido a associações incorretas e aplicações de estratégias irrelevantes;

C - erro ligado a formulação e apresentação da solução;

D - erros ligados à utilização adequada ou não dos saberes ou do saber-fazer, erro devido a dificuldade de obter informação espacial, erros devido a associações incorretas e aplicações de estratégias irrelevantes, leitura, compreensão e seleção de estratégias, de acordo com a Seção 6.4. 


\subsubsection{Item 6}

Cinco meninas não estão totalmente de acordo sobre a data da prova de Matemática.

- Andrea diz que será em agosto, dia 16, segunda- feira;

- Daniela diz que será em agosto, dia 16, terça-feira;

- Fernanda diz que será em setembro, dia 17, terça- feira;

- Patrícia diz que será em agosto, dia 17, segunda- feira;

- Tatiane diz que será em setembro, dia 17, segunda-feira.

Somente uma está certa, e as outras acertaram pelo menos uma das informações: o mês, o dia do mês ou o dia da semana. Quem está certa?
A) Andrea
B) Daniela
C) Fernanda
D) Patrícia
E) Tatiane

Análise do Item 6

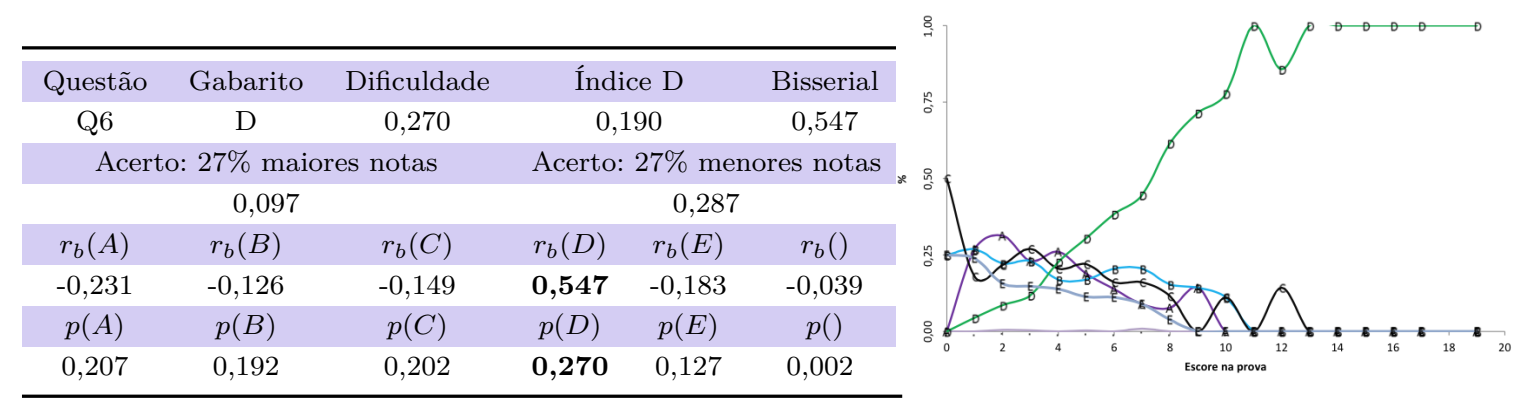

A alternativa correta discriminou bem, já que seu coeficiente bisserial foi de 0,547, o que também pode ser observado pela AGI, a qual revela que há maior proporção de escolha das alternativas erradas entre os estudantes de baixa proficiência.

O nível de dificuldade foi de 0,270, o que leva o item a ser classificado como difícil. A habilidade inferida é resolver problemas de raciocínio lógico a partir de dedução de informações de relações arbitrárias entre objetos, lugares, pessoas e/ou eventos fictícios dados.

Aqueles que escolheram alguma das alternativas erradas, seja A, B, C ou E, provavelmente desconsideraram a condição de que ao menos uma informação das outras estava correta. Assim, todas as alternativas verificam erros de lógica ou de raciocínio, segundo 
Bodin (1997), e erros devido a associações incorretas ou rigidez de pensamento, segundo Radatz (1979).

De acordo com os dados, com exceção do índice $I_{D}$, o item se comportou bem do ponto de vista psicométrico e pedagógico. 


\subsubsection{Item 7}

Rodrigo comprou três cadernos iguais em uma promoção na qual o segundo e o terceiro cadernos eram vendidos, respectivamente, com $20 \%$ e $40 \%$ de desconto sobre o preço do primeiro. No dia seguinte, terminada a promoção, Gustavo comprou três cadernos iguais aos de Rodrigo, todos sem desconto. Percentualmente, quanto Rodrigo pagou a menos que Gustavo?
A) $20 \%$
B) $22 \%$
C) $25 \%$
D) $28 \%$
E) $30 \%$

Análise do Item 7

\begin{tabular}{|c|c|c|c|c|c|}
\hline Questão & Gabarito & Dificuldade & \multicolumn{2}{|c|}{ Índice D } & Bisserial \\
\hline Q7 & A & 0,415 & \multicolumn{2}{|c|}{0,065} & 0,360 \\
\hline \multicolumn{3}{|c|}{ Acerto: $27 \%$ maiores notas } & \multicolumn{3}{|c|}{ Acerto: $27 \%$ menores notas } \\
\hline \multicolumn{3}{|c|}{0,269} & \multicolumn{3}{|c|}{0,333} \\
\hline$r_{b}(A)$ & $r_{b}(B)$ & $r_{b}(C)$ & $r_{b}(D)$ & $r_{b}(E)$ & $r_{b}()$ \\
\hline 0,360 & $-0,136$ & $-0,171$ & $-0,124$ & $-0,169$ & $-0,263$ \\
\hline$p(A)$ & $p(B)$ & $p(C)$ & $p(D)$ & $p(E)$ & $p()$ \\
\hline 0,415 & 0,094 & 0,145 & 0,098 & 0,242 & 0,006 \\
\hline
\end{tabular}

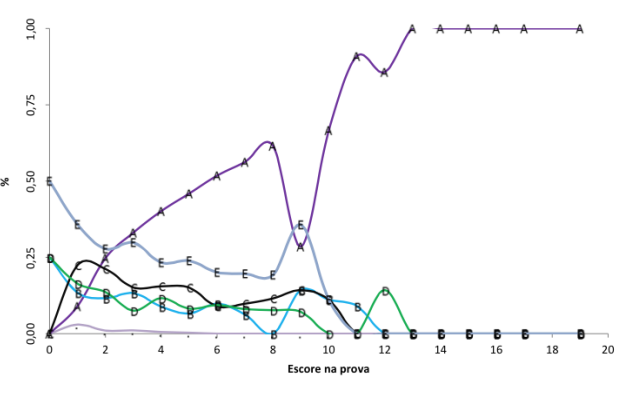

A alternativa correta discriminou bem, seu coeficiente bisserial foi de 0,360, e a AGI também denota que há maior proporção de alternativas erradas entre os estudantes de proficiência menor.

No tocante às habilidades avaliadas, infere-se, em relação à solução proposta pelo elaborador (Anexo C), que este objetivava avaliar: a resolução de situação-problema envolvendo a variação de grandezas diretamente proporcionais, e também, cuja modelagem envolva conhecimentos algébricos.

As alternativas B e D tiveram uma marcação mais baixa que as demais, provavelmente por causa do formato dos números, pois não são múltiplos de 5 ou 10. Pode ser que os alunos que marcaram ao acaso já descartam essas opções por não se assemelharem aos valores apresentados no texto-base.

O distrator E pode ser justificado por ser o valor médio entre as porcentagens de descontos, o que demonstra que houve erro na interpretação do problema, e na aprendizagem relacionada a variação de grandezas, ou seja, erros de saber - o aprendiz não tem conhecimento matemático sobre os conceitos (BODIN, 1997).

Os dados deste item também deveriam ser revistos, pois o fato de no texto-base possuir número igual ao gabarito da questão é considerado um fator de atração (Seção 
4.7), o que pode ter introduzido um viés na marcação das respostas e alunos com baixa proficiência podem ter sido beneficiados.

Nesse tipo de questionamento, com relação à comparação percentual, o item avaliaria melhor se a resposta correta não fosse igual a um dos valores apresentados no texto-base.

O nível de dificuldade de 0,415 classifica o item como mediano para os respondentes, mas o fator de atração mencionado acima pode ter contribuído para a facilidade do item. Aconselha-se rever os valores numéricos. 


\subsubsection{Item 8}

O professor Michel aplicou duas provas a seus dez alunos e divulgou as notas por meio do gráfico mostrado abaixo. Por exemplo, o aluno A obteve notas 9 e 8 nas provas 1 e 2, respectivamente; já o aluno B obteve notas 3 e 5 . Para um aluno ser aprovado, a média aritmética de suas notas deve ser igual a 6 ou maior do que 6. Quantos alunos foram aprovados?
A) 6
B) 7
C) 8
D) 9
E) 10

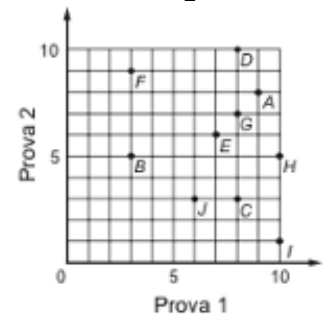

\section{Análise do Item 8}

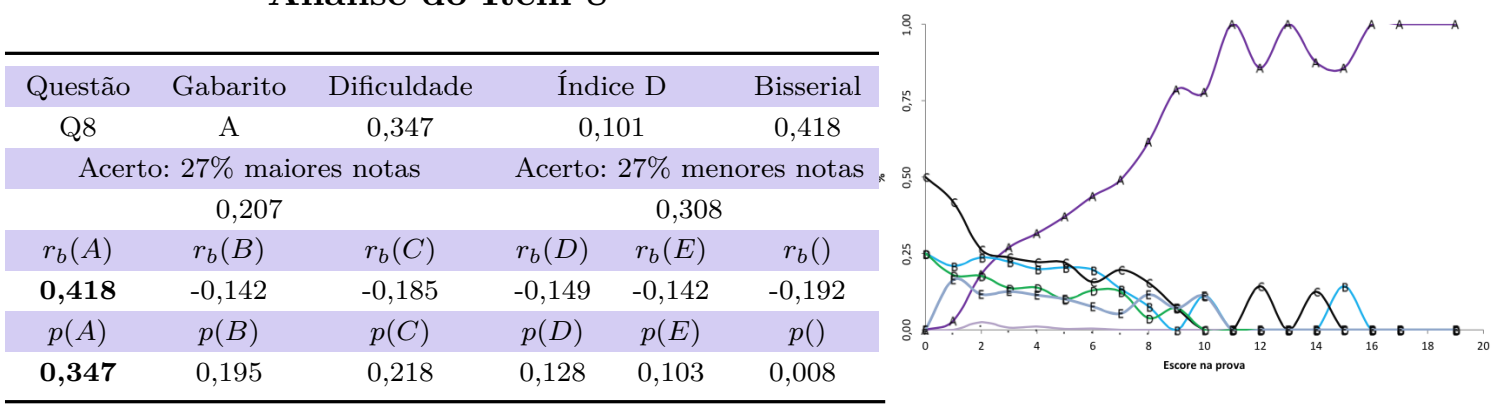

As habilidades necessárias para responder o item, em relação à solução proposta pelo elaborador (Anexo C), são: interpretar informações apresentadas por meio de coordenadas cartesianas, ou resolver situação-problema envolvendo informações apresentadas em gráficos, identificar a localização de pontos no plano cartesiano, acrescidas de uma habilidade não conexa a essas, resolver situação-problema que envolva medida de tendência central, coleta, organização e descrição de dados, o que é desaconselhável quando se pretende interpretar os erros e acertos em um item de múltipla escolha ou utilizar a teoria de resposta ao item para se fazer a análise de desempenho.

A alternativa correta discriminou bem pois seu coeficiente bisserial foi de 0,418. A AGI também denota que há maior proporção de escolha de alternativas incorretas entre os estudantes de proficiência menor.

No tocante à plausibilidade dos distratores, o processo de elaboração poderia ter escolhido distratores com maior plausibilidade, em vez de simplesmente apresentar uma sequência de números consecutivos dentre as alternativas.

Infere-se que, ao cometer o erro de saber (BODIN, 1997) no tocante à média aritmética, o aluno que marcou a opção E, apenas adicionou as duas notas, e, como a soma encontrada é maior que 6 , concluiu que todos os alunos foram aprovados. 
Para as outras alternativas incorretas, podem ser adicionadas duas características do erro cometido: erro de saber no tocante à média e erros de lógica ou de raciocínio ao selecionar de acordo com a posição no plano cartesiano, situações que não contemplam o desafio proposto, segundo Bodin (1997). Já na visão do Radatz (1979), há erros devido à dificuldade de obter informação espacial e erros devido a aplicações de regras ou estratégias irrelevantes, da seguinte forma:

- pode-se inferir que, se o aluno interpretar que quem possuir uma nota maior igual a a 6 está aprovado, este irá marcar a alternativa D;

- ao marcar $\mathrm{C}$, o aluno considerou que alunos que retiraram pelo menos uma nota maior ou igual a 6 teria sido aprovado, ou seja, pode ter destacado um quadrado de dimensões $6 \times 6$, iniciado no 0 , e todos os pontos fora da região ou no contorno seriam de alunos aprovados, considerando apenas os alunos B e J como reprovados. Esta marcação foi alta, de 21,8\%;

- ao marcar B, o aluno considerou que alunos que retiraram pelo menos uma nota maior que 6 teria sido aprovado, ou seja, pode ter destacado um quadrado de dimensões $6 \times 6$, iniciado no 0 , e todos os pontos fora da região seriam de alunos aprovados, considerando apenas os alunos B, E e J como reprovados.

Logo, o item deveria ser melhorado no tocante a aplicação de distratores plausíveis com abordagens de diferentes tipos de erro, visando a análise do erro para uma aprendizagem significativa e, ainda, por utilizar mais de uma habilidade para o mesmo item. O nível de dificuldade foi de 0,347, caracterizando-se como difícil. Aconselha-se reelaborar os distratores e abordar uma única habilidade. 


\subsubsection{Item 9}

O polígono ABCDEF é um hexágono regular. Os pontos $\mathrm{M}$ e $\mathrm{N}$ são pontos médios dos lados AF e BC, respectivamente. O hexágono ABNGHM é simétrico em relação à reta que passa por $\mathrm{M}$ e $\mathrm{N}$. Qual é a razão entre as áreas dos hexágonos ABNGHM e ABCDEF?
A) $3 / 10$
B) $4 / 11$
C) $3 / 7$
D) $7 / 15$
E) $5 / 12$

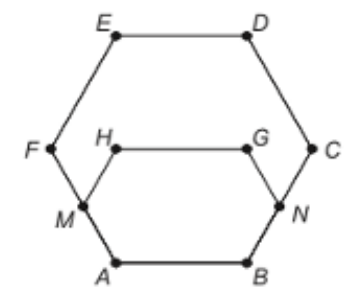

Análise do Item 9

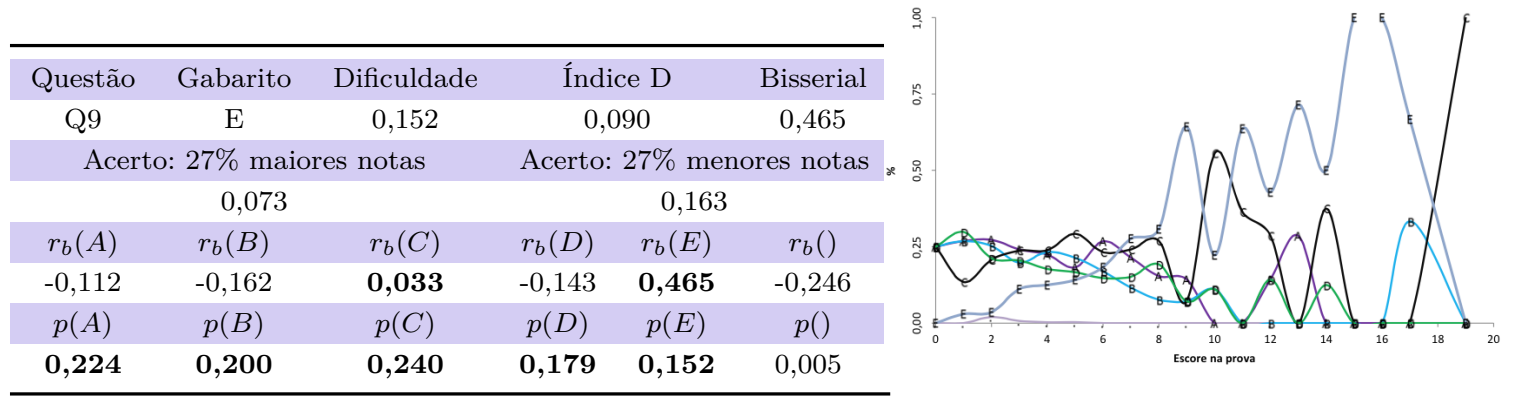

Apesar de a alternativa correta apresentar um bom coeficiente bisserial - 0,465 -, a AGI sinaliza para um comportamento ruim do item, já que há maior proporção de escolhas de alternativas erradas entre os estudantes de maior proficiência, ou até mesmo de marcações em branco.

No que se refere aos distratores, há problemas na construção do item, pois a alternativa $\mathrm{C}$ possui um fator de atração, confirmado pela porcentagem de marcação do item e do seu bisserial positivo, o que demonstra que até alunos de bom desempenho escolheram essa alternativa. Justifica-se o fator de atração devido à formatação do denominador da fração, que possui apenas um dígito, enquanto os demais possuem dois dígitos no denominador.

Como dito anteriormente na análise geral do instrumento, as alternativas desse item não são organizadas de forma trapezoidal, nem em ordenação crescente ou decrescente.

Quanto à plausibilidade dos distratores, pode-se destacar que:

- ao marcar as alternativas A ou D, o aluno pode ter realizado uma decomposição da figura, sem respeitar que decomposição deve ser realizada de forma que todas as partes possuam mesma área, das seguintes formas: 
Para a opção A: escolhendo 3 partes compreendidas pelo hexágono ABNGHM no total de 10 partes determinadas por ABCDEF.

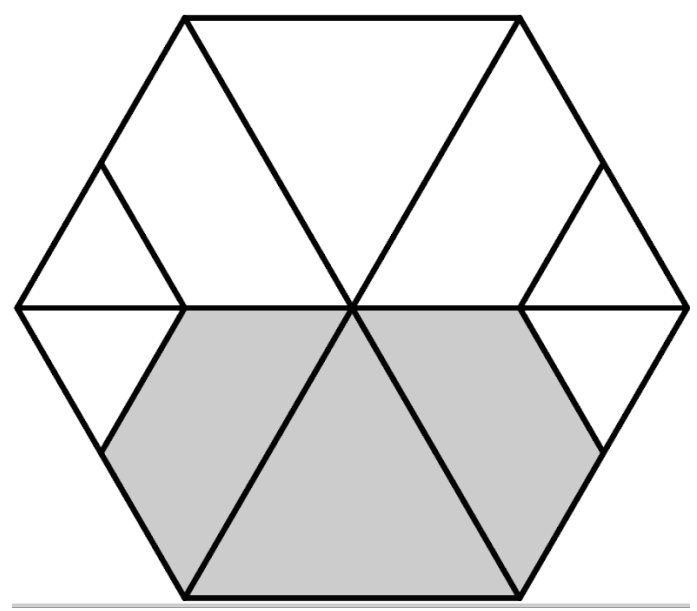

Figura 17 - Visualização da solução da alternativa A

Para a opção D: escolhendo 7 partes compreendidas pelo hexágono ABNGHM no total de 15 partes determinadas por ABCDEF.

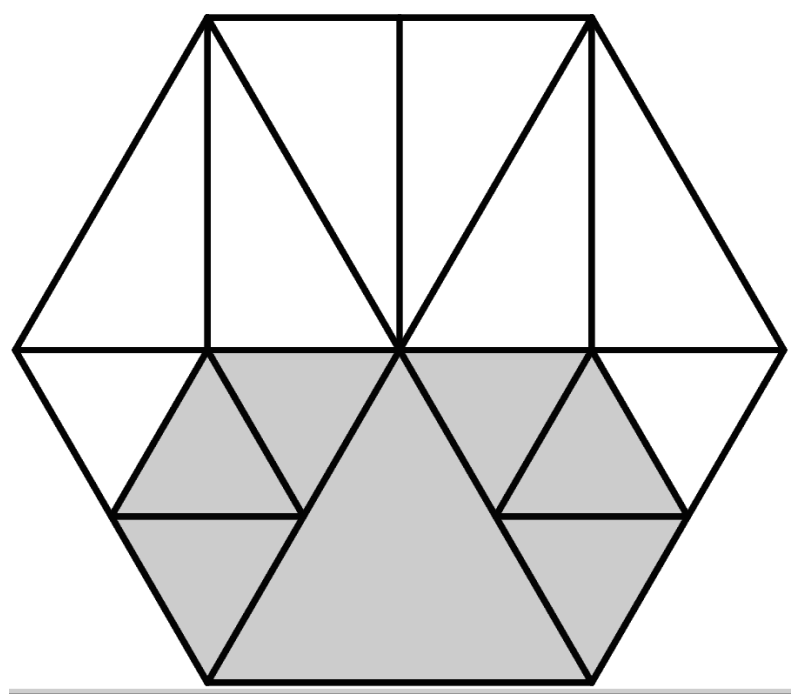

Figura 18 - Visualização da solução da alternativa D

- Nada foi inferido a respeito da alternativa B.

Vê-se em relação à solução proposta pelo elaborador, que a habilidade necessária para resolver o item é resolver problema envolvendo o cálculo de área de figura plana, reconhecer a conservação ou modificação de medidas dos lados, da área utilizando malhas triangulares.

Com relação aos erros cometidos: 
- ao marcar as alternativas $\mathrm{A}$ ou $\mathrm{D}$, infere-se que o erro cometido é relacionado à utilização adequada ou não dos saberes ou do saber-fazer, ou devido ao domínio deficiente de conteúdos, rigidez de pensamento e a aplicações de regras ou estratégias irrelevantes, segundo Bodin (1997) e Radatz (1979), respectivamente; e

- ao escolher a alternativa $\mathrm{C}$, infere-se que o erro cometido é devido à formulação da questão, segundo Casey (CLEMENTS, 1980 apud CURY, 2007).

Sugere-se reordenar e reelaborar as alternativas, e também contextualizar o item. 


\subsubsection{Item 10}

Sempre que Yurika abastece seu carro, ela enche o tanque e anota a data, a quilometragem marcada no painel e a quantidade de litros de combustível colocada. Na tabela estão os dados registrados por Yurika em dois abastecimentos consecutivos. Quantos quilômetros por litro, aproximadamente, fez o carro de Yurika nesse período?
A) 5,6
B) 9,8
C) 11,1
D) 12,9
E) 40,1

\begin{tabular}{|c|c|c|}
\hline data & $\mathrm{km}$ & litros \\
\hline$\vdots$ & $\vdots$ & $\vdots$ \\
\hline $01 / 02$ & 35723 & 32,5 \\
\hline $07 / 02$ & 36144 & 43,0 \\
\hline$\vdots$ & & $\vdots$ \\
\hline
\end{tabular}

Análise do Item 10

\begin{tabular}{cccccc}
\hline \multicolumn{1}{c}{ Questão } & Gabarito & Dificuldade & Índice $\mathrm{D}$ & Bisserial \\
\hline Q10 & $\mathrm{B}$ & 0,185 & 0,117 & 0,311 \\
Acerto: $27 \%$ maiores notas & Acerto: $27 \%$ menores notas \\
\multicolumn{7}{c}{0,066} & & & 0,183 & \\
$r_{b}(A)$ & $r_{b}(B)$ & $r_{b}(C)$ & $r_{b}(D)$ & $r_{b}(E)$ & $r_{b}()$ \\
$-0,139$ & $\mathbf{0 , 3 1 1}$ & $-0,095$ & $\mathbf{0 , 0 3 7}$ & $-0,132$ & $-0,120$ \\
$p(A)$ & $p(B)$ & $p(C)$ & $p(D)$ & $p(E)$ & $p()$ \\
0,104 & $\mathbf{0 , 1 8 5}$ & $\mathbf{0 , 2 5 1}$ & $\mathbf{0 , 2 5 6}$ & $\mathbf{0 , 1 9 5}$ & 0,008 \\
\hline
\end{tabular}

Embora o coeficiente bisserial da alternativa correta seja de 0,311, a alternativa incorreta D também apresentou bisserial positivo, evidenciando que alunos com maior proficiência também foram atraídos para este distrator. Além disso, a AGI também denota que há grande proporção de alternativas erradas entre os estudantes nas mais diversas faixas de escore, sugerindo uma má qualidade do item.

No que se refere aos distratores, infere-se que para escolher a letra A, o aluno encontrou a diferença entre os espaços percorridos e dividiu pela soma dos litros. Para a opção D, a diferença entre os espaços foi divida por 32,5, enquanto, para chegar ao valor 40,1, na alternativa E, encontrou o quociente entre as diferenças dos espaços percorridos e os litros de consumo.

Nada de plausível foi inferido em relação à alternativa $\mathrm{C}$, além de ser o valor mais próximo da diferença entre os dois consumos em litros, o que poderia justificar sua alta marcação (ver Figura 19).

A habilidade avaliada no item é resolver problema que envolva variações proporcionais, diretas ou inversas entre grandezas. Logo, os distratores exploraram a variação de acordo com essa habilidade. O nível de dificuldade foi de 0,185, sendo, assim, considerado difícil. 


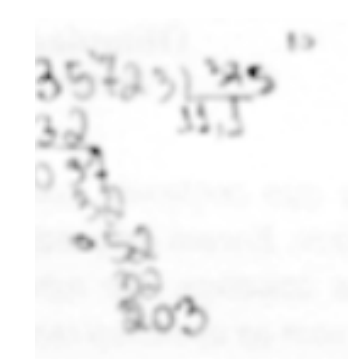

Figura 19 - Solução apresentada pelo aluno E1A15.

Como apresentado na análise geral do instrumento, o dado 32,5 é considerado irrelevante para a resolução do item. A formatação das alternativas não segue o mesmo padrão, e, de acordo com a porcentagem de marcação, verifica-se que a menor parte dos respondentes concentrou-se na alternativa $\mathrm{A}$.

Os erros associados à marcação das alternativas são ligados à utilização adequada ou não dos saberes ou do saber-fazer, segundo Bodin (1997), e erros devido a aplicações de regras ou estratégias irrelevantes, segundo Radatz (1979). No entanto, não se pode descartar que a informação a mais no texto-base pode contribuir para que haja confusão durante a resolução, que ao buscar usar todos os dados apresentados, não haja opção que contemple tal escolha. Ou seja, a formulação do item, segundo Casey (CLEMENTS, 1980 apud CURY, 2007), pode ser raiz dos erros. Segundo este mesmo autor, os erros cometidos, descartando o uso do dado irrelevante, podem ser de natureza de má compreensão e seleção de estratégias.

Como sugestão, o item deveria ser reelaborado para sanar as não conformidades com a Engenharia de Construção de Itens e retirar o dado irrelevante. 


\subsubsection{Item 11}

Todos os números de 1 a 24 devem ser escritos nas faces de um cubo, obedecendo-se às seguintes regras:

- em cada face devem ser escritos quatro números consecutivos;

- em cada par de faces opostas, a soma do maior número de uma com o menor número da outra deve ser igual a 25.

Se os números 7 e 23 estiverem escritos no cubo como na figura, qual é o menor número que pode ser escrito na face destacada em cinza?
A) 1
B) 5
C) 9
D) 11
E) 17

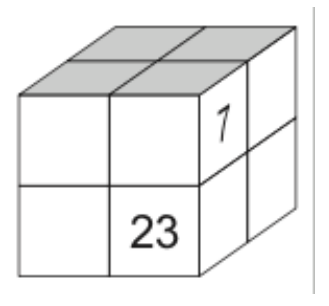

Análise do Item 11

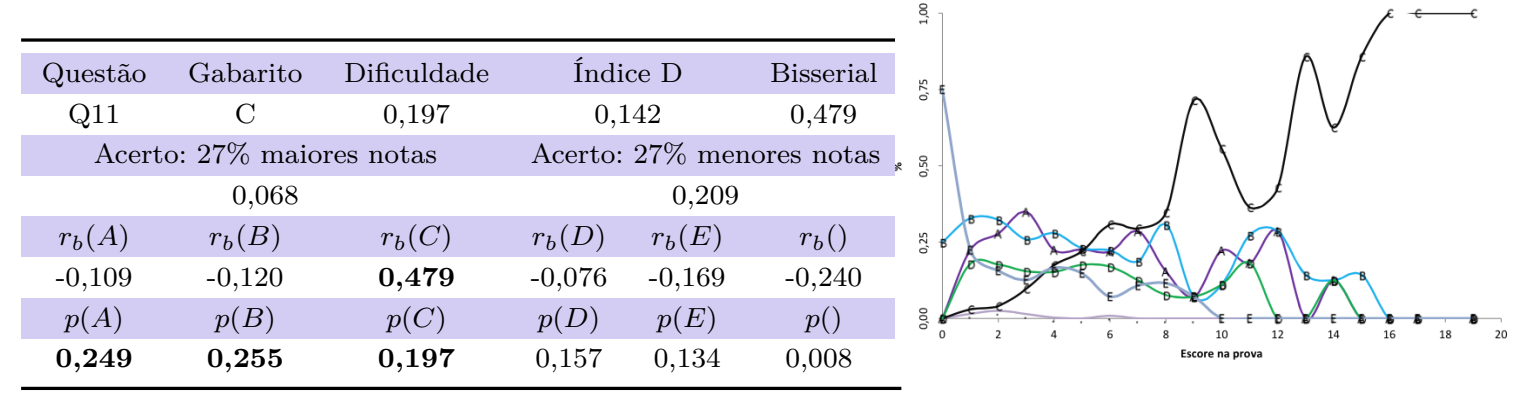

Embora o coeficiente bisserial da alternativa correta foi de 0,479, analisando o bisserial por alternativas percebe-se que este tem problemas na alternativa $\mathrm{D}$, pois alunos com maior proficiência foram atraídos também para este distrator. A AGI também denota que há grande proporção de escolha de alternativas incorretas entre os estudantes de proficiência menor, o que é esperado, mas que os alunos de maior proficiência também marcaram opções diversas ao gabarito, e até realizaram marcação em branco.

A solução proposta pelo elaborador apresenta a solução para todas as faces, ou seja:

- face da frente - 25, 24, 23 e 22

- face lateral direita - 5, 6, 7 e 8

- as outras faces seriam $(1,2,3$ e 4); ( $9,10,11$ e 12); (13, 14,15 e 16); (17,18,19 e 20). 
A habilidade inferida é resolver problemas de raciocínio lógico a partir de dedução de informações de relações de eventos fictícios dados.

O item poderia ser a reelaborado, ainda mais quanto à plausibilidade para o uso de erros que contribuem para a aprendizagem significativa. Quando se relaciona às faces opostas, a escolha da alternativa A pode ter o fator de atração relacionado ao menor número presente no conjunto de alternativas, ou seja, um erro de compreensão da situação proposta (Casey (CLEMENTS, 1980 apud CURY, 2007)) fora esta possibilidade há como caracterizar este erro de forma pedagógica.

Ao marcar a alternativa $\mathrm{B}=5$, supõe-se que o estudante pode ter escrito os antecedentes do 7 sobre a face superior, o que denota um erro de saber-fazer ou erro de lógica ou de raciocínio, segundo Bodin (1997). Ainda, segundo Radatz (1979), pode ter cometido erros devido à dificuldade de obter informação espacial e erros devido a associações incorretas ou rigidez de pensamento.

Para marcar a alternativa E, o estudante pode ter compreendido o preenchimento para as faces que apresentam números, desconsiderando a face oposta ao 7, e assumiu que as faces superior e inferior deveriam ser preenchidas com os valores de 13 até 20, como 13 não figurou entre os valos das alternativas, escolheu posicionar os números de 17 a 20 na face superior, realizando essa escolha, apresentando erros de lógica ou de raciocínio e erros devido a associações incorretas ou rigidez de pensamento, segundo Bodin (1997) e Radatz (1979) respectivamente. Acrescentando os apontamentos de Casey (CLEMENTS, 1980 apud CURY, 2007), há também erro de compreensão e apresentação da solução.

Não foi inferido um processo que justifique a escolha da alternativa D. E, novamente, há a presença de alternativas que seguem um padrão de numeração ímpar.

Logo, a situação proposta poderia ser reelaborada de forma a priorizar a elaboração de distratores que demonstrem proposições falsas plausíveis e também, ajustando o nível de dificuldade do item. 


\subsubsection{Item 12}

Começando com um quadrado de $1 \mathrm{~cm}$ de lado, formamos uma sequência de figuras, como na ilustração. Cada figura, a partir da segunda, é formada unindo-se três cópias da anterior. Os contornos destacados em vermelho das quatro primeiras figuras medem, respectivamente, $4 \mathrm{~cm}, 8 \mathrm{~cm}, 20 \mathrm{~cm}$ e $56 \mathrm{~cm}$. Quanto mede o contorno da Figura 6?
A) $88 \mathrm{~cm}$
B) $164 \mathrm{~cm}$
C) $72 \mathrm{~cm}$
D) $488 \mathrm{~cm}$
E) $492 \mathrm{~cm}$

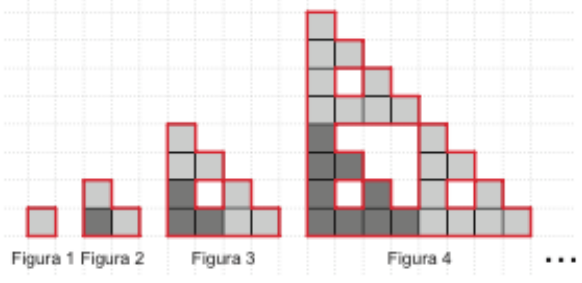

Análise do Item 12

\begin{tabular}{cccccc}
\hline Questão & Gabarito & Dificuldade & Índice D & Bisserial \\
Q12 & $\mathrm{D}$ & 0,171 & 0,108 & 0,477 \\
Acerto: & $27 \%$ maiores notas & Acerto: $27 \%$ menores notas \\
\multicolumn{5}{c}{0,073} \\
$r_{b}(A)$ & $r_{b}(B)$ & $r_{b}(C)$ & $r_{b}(D)$ & $r_{b}(E)$ & $r_{b}()$ \\
$-0,202$ & $-0,093$ & $-0,091$ & $\mathbf{0 , 4 7 7}$ & $\mathbf{0 , 0 1 8}$ & $-0,070$ \\
$p(A)$ & $p(B)$ & $p(C)$ & $p(D)$ & $p(E)$ & $p()$ \\
$\mathbf{0 , 2 5 4}$ & $\mathbf{0 , 2 6 4}$ & $\mathbf{0 , 2 2 9}$ & $\mathbf{0 , 1 7 1}$ & 0,075 & 0,007 \\
\hline
\end{tabular}

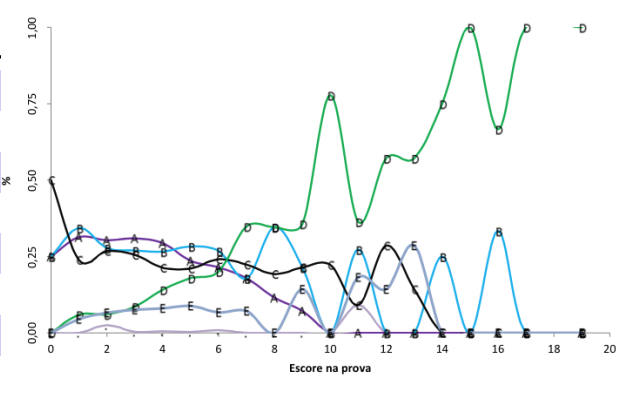

Infere-se que as habilidades necessárias para a resolução do item são: reconhecer a conservação ou modificação de medidas dos lados, do perímetro em figuras poligonais usando malha quadriculada, identificar uma expressão algébrica que expressa uma regularidade observada em sequências de números ou figuras (padrões).

Embora o coeficiente bisserial da alternativa correta seja de 0,477, analisandose o bisserial por alternativa, percebe-se que este tem problemas na alternativa E, pois alunos com com proficiência até o escore de 14 pontos foram atraídos também para este distrator, o que é confirmado pela AGI, mesmo que esta alternativa tenha apresentado uma marcação baixa de respostas.

Além disso, os bisseriais das alternativas B e C foram muito próximos de zero, evidenciando a baixa discriminação das alternativas.

No tocante à plausibilidade dos distratores, observa-se que, provavelmente, quem escolheu a alternativa:

- A, adicionou todos os números do comando que indicam os primeiros contornos, 4 $\mathrm{cm}+8 \mathrm{~cm}+20 \mathrm{~cm}+56 \mathrm{~cm}=88 \mathrm{~cm}$, presentes no texto-base, caracterizando um fator de atração. Um distrator elaborado nessa perspectiva traz pouca informação sobre a aprendizagem dos estudantes, permitindo apenas a caracterização como erro 
de compreensão.

- B, calculou o contorno da quinta figura, e não o da sexta, como era desejado. Ou seja, ao realizar o processo correto, o aluno parou numa etapa intermediária, por encontrar esse valor entre as alternativas, caracterizando-se erro levado por atração, ou de apresentação de solução, segundo Casey (CLEMENTS, 1980 apud CURY, 2007).

Pode-se afirmar também que, quem marcou a alternativa B, provavelmente interpretou, aplicou um algoritmo certo de resolução, mas, por descuido, ao encontrar um valor entre as alternativas, parou de realizar a análise da sentença. Isso pode ser considerado um "peguinha", pois o aluno realizou o processo correto mas o interrompeu. Nesse caso, houve aplicação correta, só não foi realizada o número de iterações requisitadas.

Quanto as outras alternativas, nada foi inferido pela pesquisadora.

Logo, a alternativa E poderia ser descartada por não haver uma marcação expressiva, e as alternativas A e B deveriam ser reelaboradas, ou até mesmo o texto-base, para sanar a desconformidade com a Engenharia de Construção de Itens. O nível de dificuldade foi de 0,171 , revelando-se muito difícil para os estudantes. 


\subsubsection{Item 13}

Na conta indicada a seguir, as letras $\mathrm{X}, \mathrm{Y}$ e $\mathrm{Z}$ representam algarismos distintos. Qual é o algarismo representado pela letra Z?
A) 1
B) 3
C) 5
D) 6
E) 8

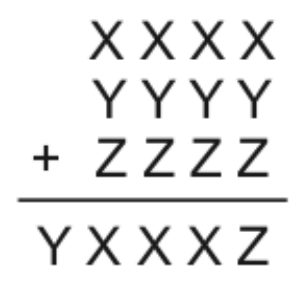

Análise do Item 13

\begin{tabular}{cccccc}
\hline \multicolumn{1}{c}{ Questão } & Gabarito & Dificuldade & Índice $\mathrm{D}$ & Bisserial \\
Q13 & $\mathrm{E}$ & 0,174 & 0,105 & 0,484 \\
Acerto: $27 \%$ maiores notas & Acerto: $27 \%$ menores notas \\
& 0,079 & & & 0,184 \\
$r_{b}(A)$ & $r_{b}(B)$ & $r_{b}(C)$ & $r_{b}(D)$ & $r_{b}(E)$ & $r_{b}()$ \\
$-0,067$ & $-0,029$ & $-0,193$ & $-0,122$ & $\mathbf{0 , 4 8 4}$ & $-0,202$ \\
$p(A)$ & $p(B)$ & $p(C)$ & $p(D)$ & $p(E)$ & $p()$ \\
0,160 & $\mathbf{0 , 1 9 7}$ & $\mathbf{0 , 2 5 9}$ & $\mathbf{0 , 2 0 4}$ & $\mathbf{0 , 1 7 4}$ & 0,006 \\
\hline
\end{tabular}

As habilidades que podem ser imputadas ao item são: resolver situação-problema com números naturais, considerando as ordens e as classes de determinada base cuja modelagem envolva conhecimentos algébricos.

Embora o coeficiente bisserial do item tenha sido de 0,484, há problemas em sua elaboração, pois os bisseriais das alternativas A e B são muito próximos de zero, o que revela a marcação dessas alternativas por alunos com escore mais alto.

No tocante à plausibilidade dos distratores, vê-se em relação à solução proposta pelo elaborador que, quem escolheu a alternativa $\mathrm{C}$, com 25,9\% de marcação, considerou o fato de, sendo $Z=5$, então $X=6$ e $Y=4$ nas parcelas. Durante o processo de adição, a soma $\mathrm{Z}$ e $\mathrm{X}$ se confirmam nesta condição, mas o $\mathrm{Y}$ seria igual a 1 , o que invalidava a situação descrita.

Nada foi inferido das outras alternativas que justifiquem processos errôneos significativos, apenas por descuido na resolução, onde os valores 1 e 6 aparecem no meio do processo resolutivo, mas não representam o algarismo procurado.

Provavelmente, o erro de quem marcou a alternativa $\mathrm{C}$ foi de lógica ou de raciocínio ou devido a associações incorretas ou rigidez de pensamento, respectivamente nas abordagens de Bodin (1997) e Radatz (1979). Para Casey (CLEMENTS, 1980 apud CURY, 2007), seria na seleção de estratégias e apresentação de solução tanto na alternativa $\mathrm{C}$ quanto para A e B.

O nível de dificuldade de 0,174 , coloca o item na categoria difícil, e, como relatado 
na análise do instrumento, o texto-base poderia ser melhor explorado para mobilizar competências para sua resolução. 


\subsubsection{Item 14}

Rosane percebeu que seu antigo relógio de parede tinha parado às 9 horas. Ela deu corda no relógio, colocando-o para funcionar sem acertar o horário, e foi imediatamente ao mercado. Chegou ao mercado às 10 horas e 10 minutos. Fez suas compras em 1 hora e voltou para casa. Entrando em casa, notou que o relógio de parede marcava 10 horas e 40 minutos. Se Rosane realizou os percursos de ida e volta ao mercado em tempos iguais, a que horas ela entrou em casa?
A) 10 horas e 50 minutos
B) 11 horas e 10 minutos
C) 11 horas e 30 minutos
D) 11 horas e 40 minutos
E) 11 horas e 50 minutos

Análise do Item 14

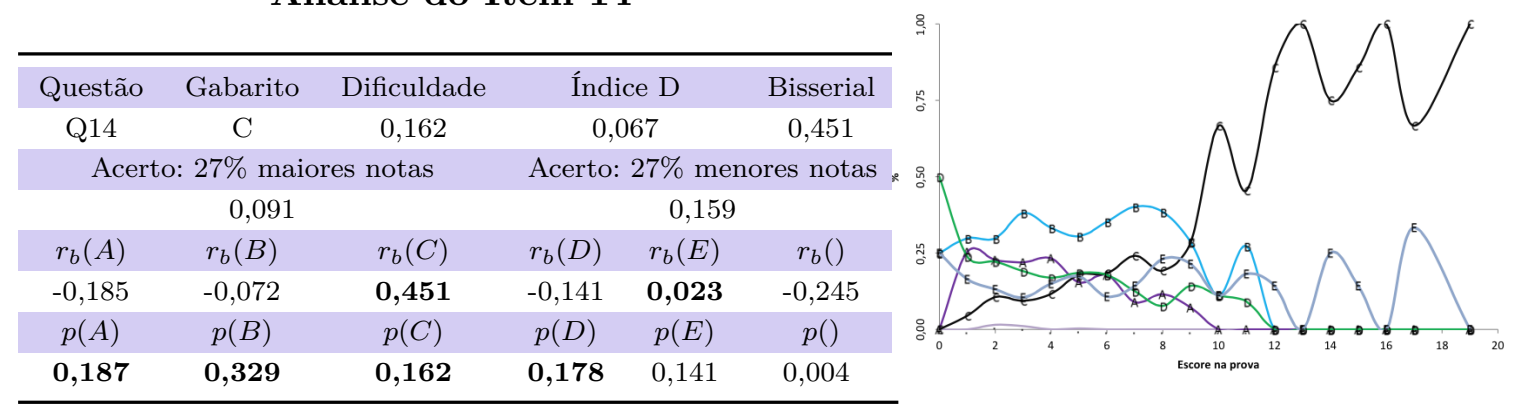

Analisando a plausibilidade dos distratores:

- a alternativa B, embora incorreta, atraiu significativa parcela dos estudantes, 32,9\%, pois possui um resultado incompleto da interpretação, com dados no texto-base "Chegou ao mercado às 10 horas e 10 minutos. Fez suas compras em 1 hora e voltou para casa", logo, o respondente adicionou esses valores, obtendo 11h10min;

- a alternativa D, da mesma forma que a B, como no texto-base tem-se que "Fez suas compras em 1 hora e voltou para casa. Entrando em casa, notou que o relógio de parede marcava 10 horas e 40 minutos", assim o aluno ao escolher esta opção adicionou os valores deste trecho e obteve 11 hora e 40 minutos;

- as alternativas A e E, com marcações de 18,7\% e 14,1\%, respectivamente, podem ser justificadas por uma leitura flutuante e sem significado do texto-base, adicionando valores nele encontrados (ver Figura 20). 


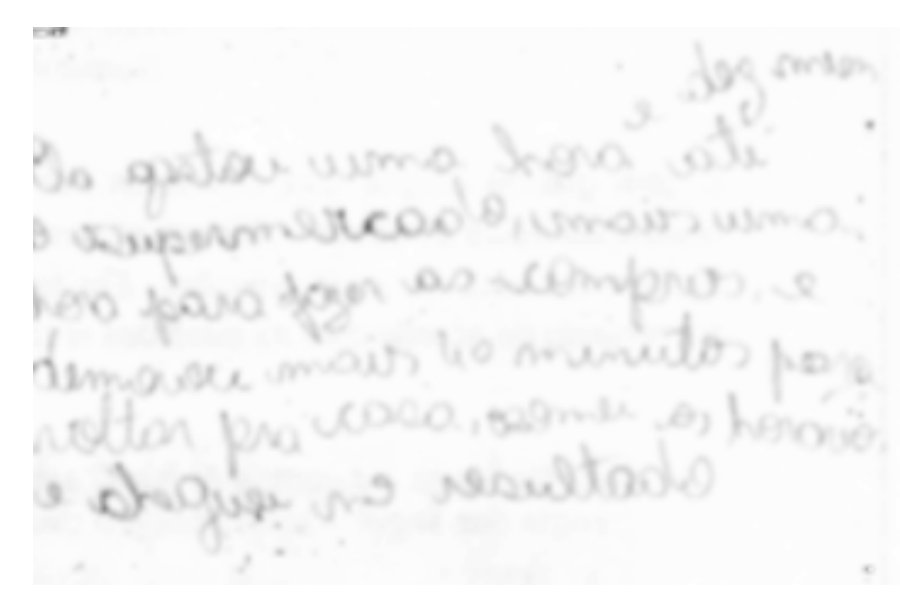

Figura 20 - Solução apresentada pelo aluno E2A10.

Associando essas escolhas às categorização dos erros temos como inferência para as alternativas $\mathrm{B}$ e $\mathrm{D}$, que há erros relacionados à utilização adequada ou não dos saberes ou do saber-fazer e erros de lógica e raciocínio, para Bodin (1997). Para Radatz (1979), há erro devido a associações incorretas ou rigidez de pensamento. E, para Casey (CLEMENTS, 1980 apud CURY, 2007), erro causado pela leitura, compreensão e seleção de estratégias, para todas as inferências.

Já para as alternativas A e E, acrescentam-se erros relacionados à aplicação de regras ou estratégias irrelevantes e erros de saber-fazer, segundo Radatz (1979) e Bodin (1997), respectivamente.

As habilidades inferidas para o desafio proposto no item dizem respeito a resolver problema envolvendo operação com sistema de medida de tempo juntamente com resolver problemas de raciocínio lógico a partir de dedução de informações de relações arbitrárias entre objetos, lugares, pessoas e/ou eventos fictícios dados.

Embora o coeficiente bisserial do item tenha sido de 0,451, analisando-se o bisserial por alternativa, percebe-se que este item tem problema na alternativa $\mathrm{E}$, pois alunos com maior proficiência foram atraídos também para este distrator, o que é confirmado pelo comportamento da AGI.

Assim, como sugestão, a alternativa E poderia ser descartada ou substituída e o texto-base poderia ser reelaborado. O nível de dificuldade de 0,162 caracteriza o item como difícil para os respondentes. 


\subsubsection{Item 15}

Télio comprou laranjas, maçãs e uvas no mercado. O preço por quilograma de cada fruta está na tabela abaixo. Metade do peso total da compra era de maçãs e o peso das uvas era o dobro do peso das laranjas. Se Télio gastou $\mathbf{R} \$ 38,00$, quantos quilogramas de frutas ele comprou?
A) 10
B) 11
C) 12
D) 13
E) 14

\begin{tabular}{|c|c|}
\hline \multicolumn{2}{|c|}{$\begin{array}{c}\text { Preços (R\$) por } \\
\text { quilograma }\end{array}$} \\
\hline Maçã & 3,00 \\
\hline Uva & 4,00 \\
\hline Laranja & 2,00 \\
\hline
\end{tabular}

Análise do Item 15

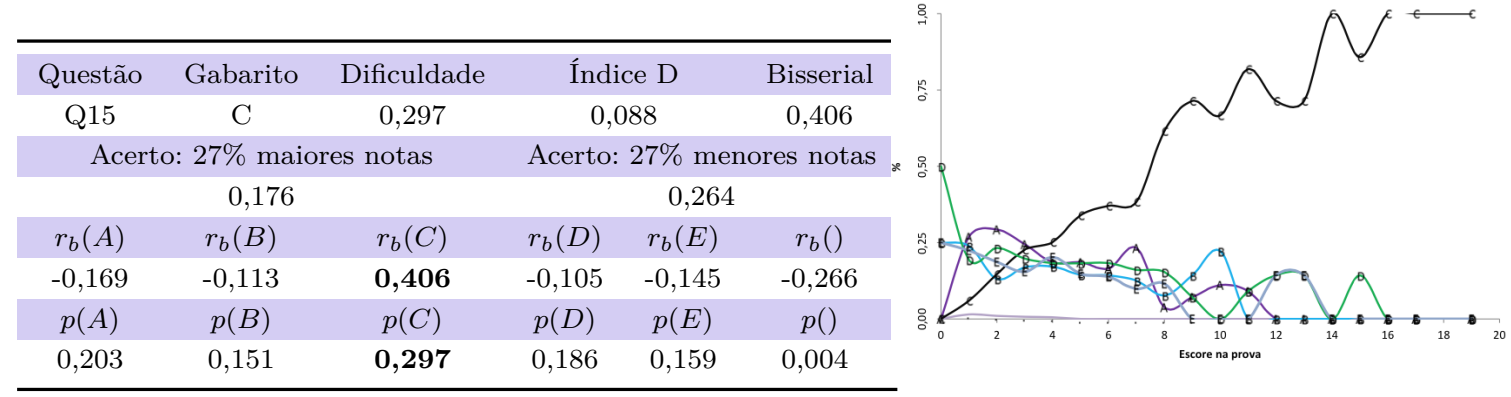

Infere-se em relação à solução proposta pelo elaborador que a habilidade necessária para se resolver o item é resolver situação-problema cuja modelagem envolva conhecimentos algébricos.

À luz da Engenharia de Construção de Itens o item, com coeficiente bisserial do item de 0,406, obteve boa distribuição de marcação de respostas entre as alternativas incorretas, sendo o gabarito o de maior escolha pelos estudantes, embora candidatos de maior proficiência, segundo a AGI, tenham optado pela alternativa D. Com coeficiente de dificuldade de 0,297, o item enquadra-se como difícil.

Com relação aos distratores, infere-se a não construção dos mesmo de forma a justificar caminhos errôneos para a resolução do item, já que são apresentados apenas como números consecutivos, sem justificativas claras de possíveis caminhos que poderiam ser seguidos pelos estudantes que desconhecem a resposta correta.

No entanto, infere-se que, ao marcar a alternativa B, o aluno apenas realizou uma testagem para encontrar algum valor entre as alternativas, ou seja, com $5 \mathrm{~kg}$ de uva e 6 $\mathrm{kg}$ de maça, obtém-se $\mathrm{R} \$ 38,00$. Assim, com $11 \mathrm{~kg}$ dessas frutas, obtém o valor procurado, mas desconsidera as condições de comprar todos os tipos de frutas e a quantidade que se relaciona entre uvas e maças. Ao escolher a opção D, possivelmente desconsiderou as condições, trabalhando com $7 \mathrm{~kg}$ de laranjas e $6 \mathrm{~kg}$ de uvas. 
De acordo com estes apontamentos, os erros inferidos são erro de saber (BODIN, 1997) e de domínio deficiente de conteúdos e aplicação de regras e estratégias irrelevantes (RADATZ, 1979). Além de erro de compreensão e seleção de estratégias (Casey (CLEMENTS, 1980 apud CURY, 2007)).

Logo, há necessidade de reelaboração dos distratores. 


\subsubsection{Item 16}

A mãe de Lúcia pediu para ela não comer mais de 10 docinhos por dia. Além disso, se em um dia ela comer mais de 7 docinhos, nos dois dias seguintes não poderá comer mais de 5 docinhos em cada dia. Qual é o maior número de docinhos que Lúcia pode comer durante um período de 29 dias seguidos, obedecendo ao pedido de sua mãe?
A) 203
B) 204
C) 206
D) 213
E) 290

Análise do Item 16

\begin{tabular}{cccccc}
\hline Questão & Gabarito & Dificuldade & Índice D & Bisserial \\
Q16 & $\mathrm{C}$ & 0,201 & 0,040 & 0,261 \\
Acerto: & $27 \%$ maiores notas & Acerto: $27 \%$ menores notas \\
\multicolumn{5}{c}{0,119} \\
$r_{b}(A)$ & $r_{b}(B)$ & $r_{b}(C)$ & $r_{b}(D)$ & $r_{b}(E)$ & $r_{b}()$ \\
$-0,019$ & $-0,028$ & $\mathbf{0 , 2 6 1}$ & $-0,088$ & $-0,135$ & $-0,103$ \\
$p(A)$ & $p(B)$ & $p(C)$ & $p(D)$ & $p(E)$ & $p()$ \\
$\mathbf{0 , 2 5 0}$ & 0,189 & $\mathbf{0 , 2 0 1}$ & 0,159 & 0,198 & 0,003 \\
\hline
\end{tabular}

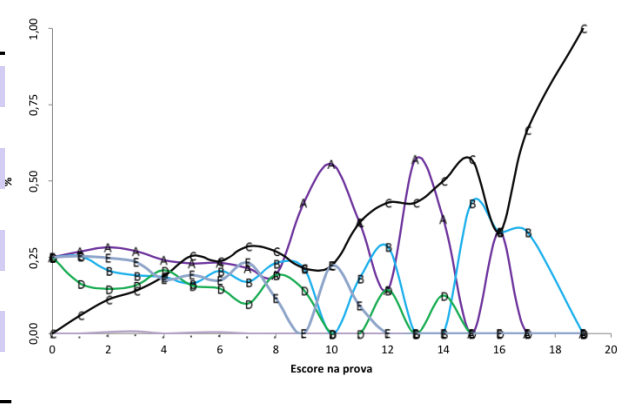

O nível de dificuldade de 0,201 o que caracteriza o item como difícil. O coeficiente bisserial da alternativa correta foi de 0,261 , pela a AGI verificamos que o item não discriminou adequadamente, fato pode ser confirmado ao tomamos os coeficientes bisseriais das alternativas incorretas. Percebe-se que os bisseriais das alternativas A, B e D são muito próximos de 0 , mesmo sendo negativos, o que indica a escolha dos distratores por uma proporção elevada de estudantes com escore mais alto.

Além disso, em várias alternativas incorretas, ocorreram percentuais de marcação muito próximas do acerto ao acaso, inclusive no gabarito a marcação foi de $20,1 \%$ o que sugere marcação ao acaso para todas as alternativas, revelando que os alunos da amostra não possuem habilidade necessária para responder o item, indicando necessidade de análise pedagógica mais acurada do item. No tocante a plausibilidade dos distratores, infere-se que as alternativas podem ser justificadas na sua maioria:

- a alternativa A foi marcada por quem interpretou que a melhor escolha seria a que indicasse que Lúcia comesse 7 docinhos por dia, desconsiderando que nos dois últimos dias poderia alterar sua dieta;

- ao escolher alternativa B, possivelmente o estudante considerou que a dieta poderia ser modificada, mas escolheu comer 10 docinhos no penúltimo dia; 
- provavelmente, a alternativa E foi escolhida por quem não considerou a penalidade de se comer menos nos dois dias que se seguem se Lúcia comesse 10 docinhos em um dia, e considerou uma dieta de 10 docinhos por dia durante todo o período;

- nada foi inferido de relevante para alternativa D.

Todas essas hipóteses de possíveis explicações para os erros cometidos são embasadas em uma mesma habilidade de validação da construção do item: resolver problemas de raciocínio lógico a partir de dedução de informações de relações arbitrárias entre objetos, lugares, pessoas e/ou eventos fictícios dados, com o objetivo de maximizar o evento.

Com relação a categorização dos erros inferidos, pode-se afirmar que:

- para a alternativa A, houve erros de lógica ou de raciocínio, segundo Bodin (1997), e erros devido a associações incorretas ou rigidez de pensamento, de acordo com Radatz (1979). Da mesma forma, pode-se explicar a escolha da opção E, mas neste caso, como o aluno escolheu o valor máximo, provavelmente não compreendeu as penalidade de seu consumo, ou seja, ocorreu erro de compreensão e seleção de estratégias, segundo Casey (CLEMENTS, 1980 apud CURY, 2007);

- para quem escolheu a opção B, houve compreensão da condição da dieta, mas o aluno cometeu erro devido a aplicação de regras ou estratégias irrelevantes, de acordo com Radatz (1979), e de seleção de estratégias, segundo Casey (CLEMENTS, 1980 apud CURY, 2007).

Sugere-se que o item seja reelaborado, devido ao coeficiente bisserial que evidenciou a não-discriminação. 


\subsubsection{Item 17}

Gustavo possui certa quantidade de moedas de 1, 10, 25 e 50 centavos, tendo pelo menos uma de cada valor. É impossível combiná-las de modo a obter exatamente 1 real. Qual é o maior valor total possível para suas moedas?
A) 86 centavos
B) 1 real e 14 centavos
C) 1 real e 19 centavos
D) 1 real e 24 centavos
E) 1 real e 79 centavos

Análise do Item 17

\begin{tabular}{cccccc}
\hline \multicolumn{1}{c}{ Questão } & Gabarito & Dificuldade & Índice $\mathrm{D}$ & Bisserial \\
Q17 & $\mathrm{C}$ & 0,106 & 0,037 & 0,293 \\
Acerto: $27 \%$ maiores notas & Acerto: $27 \%$ menores notas \\
$r_{b}(A)$ & $r_{b}(B)$ & $r_{b}(C)$ & $r_{b}(D)$ & $r_{b}(E)$ & $r_{b}()$ \\
$-0,125$ & $-0,051$ & $\mathbf{0 , 2 9 3}$ & $\mathbf{0 , 0 8 0}$ & $-0,044$ & $-0,116$ \\
$p(A)$ & $p(B)$ & $p(C)$ & $p(D)$ & $p(E)$ & $p()$ \\
$\mathbf{0 , 4 6 7}$ & 0,095 & $\mathbf{0 , 1 0 6}$ & $\mathbf{0 , 1 4 2}$ & $\mathbf{0 , 1 8 6}$ & 0,005 \\
\hline
\end{tabular}

Embora o coeficiente bisserial do item tenha sido de 0,293, analisando o bisserial por alternativa, percebe-se que este tem problemas na alternativa $\mathrm{D}$, que apresentou bisserial positivo, além das alternativas $\mathrm{B}$ e E, que evidenciaram valores próximos ao zero. A AGI também confirma esse problema generalizado, com o sobe e desce das curvas de proporção de marcação de cada alternativa.

Em relação a Engenharia de Construção Itens, a alternativa A apresenta forte atração devido a sua estrutura, pois é a única que apresenta apenas centavos em seu texto, além de ser o resultado da adição dos números do texto-base. Por conta desses desvios, a alternativa A tornou-se tão atrativa, com 46,7\% de marcação, evidenciando a necessidade de ser descartada em um processo de reelaboração do item. A alternativa E poderia ser marcada pela simples verificação de que é um valor que pode ser construído com as moedas em questão, sem respeitar a impossibilidade de se ter um real. Além disso, é o maior valor apresentado entre as alternativas.

As outras duas alternativas são semelhantes na construção, pois não respeitam a condição imposta de impossibilidade de um real, e nem são os maiores valores (ver Figura 21).

A habilidade, inferida a partir da visão do elaborador, é resolver problemas de raciocínio lógico a partir de dedução de informações de relações arbitrárias entre objetos, lugares, pessoas e/ou eventos fictícios dados. 


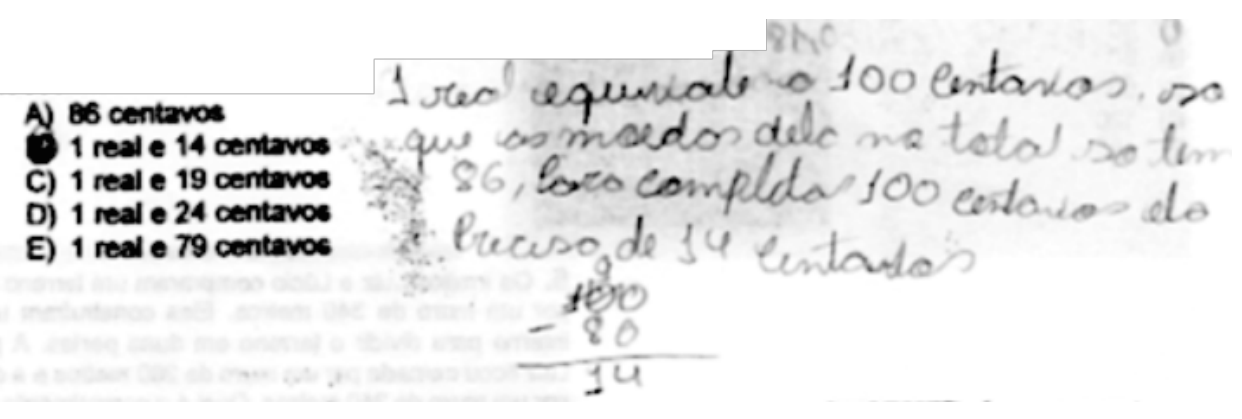

Figura 21 - Solução apresentada pelo aluno E1A10.

O nível de dificuldade de 0,106 caracteriza o item como difícil, possivelmente devido ao poder de atração da alternativa A.

Com relação a categorização dos erros, de acordo com Bodin (1997), Radatz (1979) e Casey (CLEMENTS, 1980 apud CURY, 2007):

- para a alternativa A, seria de formulação do item ou de seleção de estratégias e erro devido a associações incorretas ou de rigidez de pensamento;

- para a alternativa E, seria de de saber fazer ou devido a aplicações de regras ou estratégias irrelevantes ou de leitura, compreensão e seleção de estratégias;

- para as alternativas B e D, seria de saber fazer, de lógica e de raciocínio ou erros devido a aplicações de regras, estratégias irrelevantes, de leitura, compreensão e seleção de estratégias.

Assim, o item deveria ser reelaborado devido ao fator de atração. 


\subsubsection{Item 18}

O número 2014 tem quatro algarismos distintos, um ímpar e três pares, sendo um deles 0. Quantos números possuem exatamente essas características?
A) 60
B) 180
C) 360
D) 420
E) 540

Análise do Item 18

\begin{tabular}{cccccc}
\hline Questão & Gabarito & Dificuldade & Índice $\mathrm{D}$ & Bisserial \\
Q18 & $\mathrm{E}$ & 0,124 & 0,075 & 0,291 \\
Acerto: & $27 \%$ maiores notas & \multicolumn{1}{c}{ Acerto: $27 \%$ menores notas } \\
\multicolumn{5}{c}{0,049} \\
$r_{b}(A)$ & $r_{b}(B)$ & $r_{b}(C)$ & $r_{b}(D)$ & $r_{b}(E)$ & $r_{b}()$ \\
$-0,149$ & $\mathbf{0 , 0 0 4}$ & $\mathbf{0 , 0 2 3}$ & $-0,069$ & $\mathbf{0 , 2 9 1}$ & $-0,106$ \\
$p(A)$ & $p(B)$ & $p(C)$ & $p(D)$ & $p(E)$ & $p()$ \\
$\mathbf{0 , 2 3 0}$ & $\mathbf{0 , 2 3 5}$ & $\mathbf{0 , 2 0 0}$ & $\mathbf{0 , 2 0 3}$ & $\mathbf{0 , 1 2 4}$ & 0,009 \\
\hline
\end{tabular}

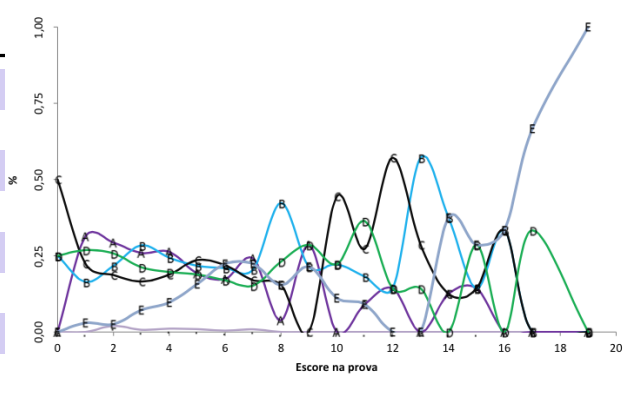

Infere-se em relação à solução proposta pelo elaborador que a habilidade verificada no item é resolver o problema de contagem utilizando o princípio multiplicativo ou noções de permutações e/ou combinações simples.

Com relação a marcação das alternativas:

- ao marcar a opção A, o aluno fixou o zero em uma posição e, pelo principio multiplicativo, preencheu as posições que restam com as possibilidades que necessitava: 5 números ímpares poderiam ocupar uma posição, 4 números pares (exceto o 0 ) ocupariam a outra e, por ultimo, um dos outros 3 números pares ocuparia a ultima posição, assim, encontrou $5 \times 4 \times 3=60$;

- para marcar o opção B, o aluno acrescentaria que o zero poderia ser colocado em três casas, ou seja, calcularia $60 \times 3=180$;

- para marcar letra C, o aluno pode ter considerado 2 formas possíveis de solução: a primeira, iniciando com um número ímpar, fixando o zero em uma das três posições e aplicando o princípio multiplicativo como a resposta dada na opção anterior; a segunda, iniciando por um número par, com o mesmo raciocínio, teríamos pelo principio multiplicativo $4 \times 3 \times 3 \times 5$. Adicionando ambas, chegaria a $180+180=$ 360. 
- para marcar a opção D, infere-se que o aluno realizou as operações justificadas para o erro na alternativa $\mathrm{A}$ e adicionou o raciocínio utilizado em $\mathrm{C}$, adicionando os valores encontrados no final.

Com relação à categorização dos erros, infere-se para as alternativas A e B, o erro de saber-fazer entrelaçado com erros de lógica ou de raciocínio; para C e D, erros relacionados à utilização adequada ou não dos saberes ou do saber-fazer entrelaçado com erros de lógica ou de raciocínio, do ponto de vista de Bodin (1997).

Para Radatz (1979), seriam erros devido a associações incorretas ou rigidez de pensamento, para as alternativas A e B, e a aplicações de regras ou estratégias irrelevantes, para marcação em C e D.

Complementando, para Casey (CLEMENTS, 1980 apud CURY, 2007), seria erro de compreensão, seleção de estratégias, manipulação das habilidade e apresentação da solução para todos os casos acima.

Embora o coeficiente bisserial da alternativa correta seja de 0,291, nota-se que este tem problemas nas alternativas B e C, pois apresentaram bisseriais positivos, e na alternativa $\mathrm{D}$, com bisserial bem próximo de zero, apesar de negativo. Há fator de atração pelo formato da alternativa A, que difere aos demais. Esses dados indicam que o item não cumpriu o seu papel no que diz respeito à discriminação, fato evidenciado também pelo sobe e desce das curvas representativas dos percentuais de marcação por alternativa ilustradas na AGI.

Do ponto de vista pedagógico, o item apresenta-se contexto apenas escolar, na própria Matemática. O resultado evidencia também o despreparo dos estudantes em relação ao que foi avaliado no item, já que o nível de dificuldade alto foi evidenciado por seu valor de 0,124 , indicando que apenas $12,4 \%$ dos respondes acertaram. 


\subsubsection{Item 19}

Um cubo de madeira foi pintado de vermelho e depois cortado em n3 cubinhos iguais, $\mathbf{n}>2$. Alguns desses cubinhos ficaram sem nenhuma face pintada e outros com uma, duas ou três faces pintadas. Se o número de cubinhos sem nenhuma face pintada é igual ao número de cubinhos com exatamente uma face pintada, qual é o valor de $n$ ?
A) 7
B) 8
C) 9
D) 10
E) 11

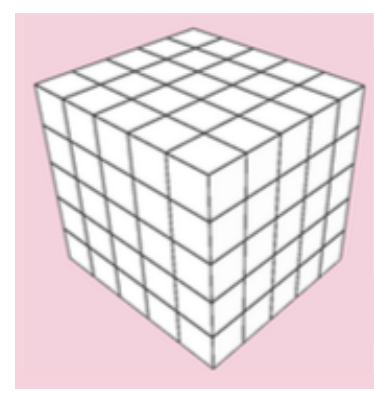

Análise do Item 19

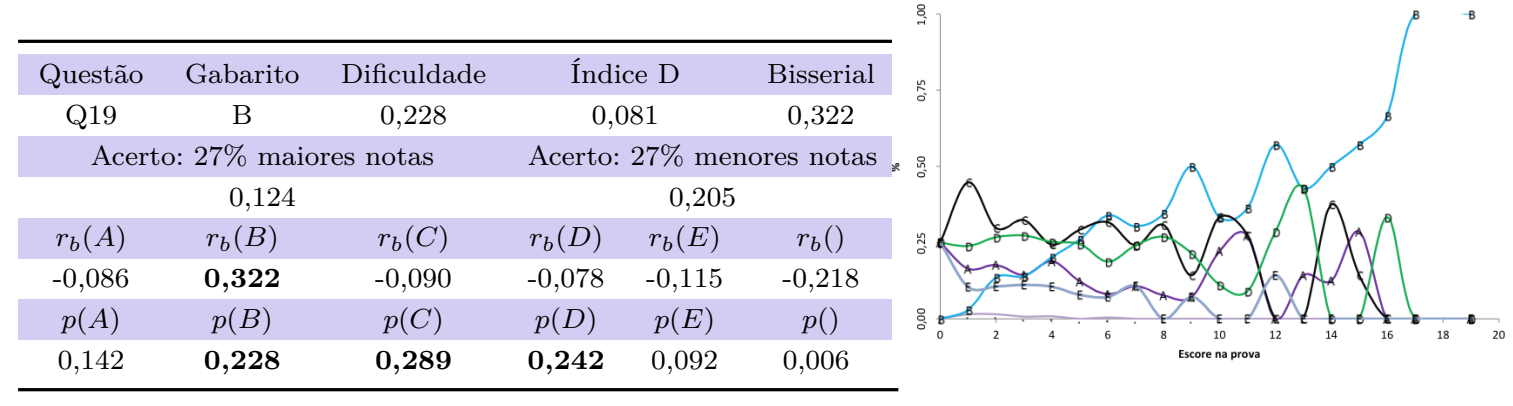

Embora o coeficiente bisserial da alternativa correta seja de 0,322, verifica-se que os bisseriais das alternativas A, C e D possuem valores próximos ao zero, apesar de negativos. Esses dados indicam que o item não cumpriu bem seu papel de discriminar, conforme evidenciado na AGI, com o sobe e desce das curvas de proporção marcação por alternativa à medida que se avança na escala de desempenho no teste

Assim como ocorreu em itens anteriores, observa-se uso de números consecutivos como possibilidade de resposta nas alternativas, o que dificulta a inferência sobre a plausibilidade de cada um deles do ponto de vista dos raciocínios possíveis dos estudantes que não compreenderam o desafio proposto ou não desenvolveram alguma das habilidades avaliada pelo item.

As alternativas C e D obtiveram proporção marcação de resposta superior à do gabarito, onde se infere apenas a contagem dos cubos da base da figura para justificar a marcação em $\mathrm{C}$, ou a contagem das faces expostas dos cubos da base da figura, para justificar a marcação em D. Fica claro, a partir desta inferência, o despreparo dos alunos em frente a esta situação-problema.

Observa-se, em relação à solução proposta pelo elaborador, que as habilidades inferidas para resolução deste item são: resolver problema envolvendo o cálculo de área 
e volume de figuras geométricas, resolver situação-problema que envolva conhecimentos geométricos de espaço e forma, utilizar conhecimentos geométricos de espaço e forma na seleção de argumentos propostos como solução de problemas, resolver situação problema cuja modelagem envolva conhecimentos algébricos.

O nível de dificuldade de 0,228 revela que o item apresentou-se difícil para os respondentes, que é verificada pelo uso de expressão algébrica de terceiro grau, o que não é trabalhado nos anos finais do ensino fundamental, logo os erros associados são devido ao saber, dificuldade de linguagem, obter informação espacial, domínio deficiente de habilidades. 


\subsubsection{Item 20}

Rodrigo brinca com uma fita de dois metros, com marcas de centímetro em centímetro. Começando pela ponta da marca $0 \mathrm{~cm}$, ele dobra a fita várias vezes em zigue-zague, como na figura, sobrepondo pedaços de fita de mesmo tamanho até dobrar um último pedaço, que pode ser menor do que os demais. Ele observa que as marcas de $49 \mathrm{~cm}$ e de $71 \mathrm{~cm}$ ficaram sobrepostas em pedaços vizinhos. Ele observa também que a marca de $139 \mathrm{~cm}$ ficou alinhada com elas. Com qual marca do penúltimo pedaço a ponta final da fita ficou sobreposta?
A) $160 \mathrm{~cm}$
B) $176 \mathrm{~cm}$
C) $184 \mathrm{~cm}$
D) $190 \mathrm{~cm}$
E) $196 \mathrm{~cm}$

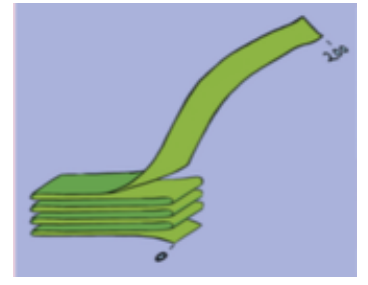

Análise do Item 20

\begin{tabular}{cccccc}
\hline \multicolumn{1}{c}{ Questão } & Gabarito & Dificuldade & Índice $\mathrm{D}$ & Bisserial \\
Q20 & $\mathrm{D}$ & 0,180 & 0,035 & 0,206 \\
Acerto: & $27 \%$ maiores notas & Acerto: $27 \%$ menores notas \\
$r_{b}(A)$ & 0,108 & & & 0,143 & $r_{b}(E)$ \\
$-0,138$ & $\mathbf{0 , 0 0 6}$ & $\mathbf{0 , 0 0 5}$ & $\mathbf{0 , 2 0 6}$ & $-0,051$ & $-0,220$ \\
$p(A)$ & $p(B)$ & $p(C)$ & $p(D)$ & $p(E)$ & $p()$ \\
$\mathbf{0 , 2 3 0}$ & $\mathbf{0 , 2 1 8}$ & $\mathbf{0 , 1 9 4}$ & $\mathbf{0 , 1 8 0}$ & 0,175 & 0,004
\end{tabular}

O item apresentou baixo coeficiente bisserial, de 0,206, além de duas das alternativas incorretas, B e C, com valores positivos, e a opção E, com valor negativo próximo do zero. Esses dados, por si só, indicam que o item não discriminou. Esse fato é corroborando pelo formato da AGI, com curvas que se misturam sem evidenciar o que se deseja em termos de escolhas dos respondentes à medida que se avança na escala de desempenho.

No tocante as habilidades necessárias para se resolver o item, infere-se as seguintes em relação a solução proposta pelo elaborador: identificar regularidade observada em sequências de números, identificar divisores e múltiplos de números naturais, interpretar e localizar a movimentação de objetos e sua representação no espaço bidimensional e utilizar conhecimentos geométricos de espaço e forma na seleção de argumentos propostos como solução de problemas do cotidiano.

O nível elevado de dificuldade é demonstrado por seu valor de 0,18. Observa-se também uma distribuição muito regular de marcação entre as alternativas, o que evidencia marcação ao acaso de respostas em todas as alternativas.

Não foi encontrada uma justificativa para a plausibilidade dos valores apresentados 
nas alternativas B e E.

Pode-se inferir que, ao escolher a alternativa A, o aluno considerou a dobra com $20 \mathrm{~cm}$, ou seja $200 \mathrm{~cm}$ está sobre $160 \mathrm{~cm}$. Essa escolha é devida à condição de todos os pedaços de dobra terem o mesmo tamanho, verificando. a sobreposição de $49 \mathrm{~cm}$ e $71 \mathrm{~cm}$, mas não a condição relacionada à medida de 139 cm.

Quanto a escolher a alternativa C, o aluno possivelmente considerou que $49 \mathrm{~cm}$ e $71 \mathrm{~cm}$ se sobrepõem e são marcas de dobra, e, como sua distância é $22 \mathrm{~cm}$, cada dobra possui $11 \mathrm{~cm}$ de comprimento. Observando a regularidade, a última dobra seria em 193 cm. Além disso, como $200 \mathrm{~cm}$ dista $7 \mathrm{~cm}$ dessa última dobra, esse pedaço estará sobreposto a $184 \mathrm{~cm}$. Desse modo, o aluno desconsiderou a posição do $139 \mathrm{~cm}$ e a posição inicial.

Os erros podem ser categorizados como devido a associação incorretas ou rigidez de pensamento para a alternativa A, considerando apenas a divisão em partes iguais; $e$ erro de lógica ou de raciocínio para a alternativa C. Para Casey (CLEMENTS, 1980 apud CURY, 2007), seria erro de compreensão, seleção de estratégias e apresentação de solução.

Se a aplicação da primeira fase da OBMEP fosse pré-testada com o grupo que respondeu o item, este não estaria adequado e precisaria ser reelaborado por apresentar problemas quanto aos bisseriais das alternativas. Além disso, o texto-base deveria ser mais claro com relação ao exemplo apresentado na figura. 



\section{Considerações Finais}

\section{Em relação ao estudo}

Ao iniciar este estudo sobre a Olimpíada Brasileira de Matemática das Escolas Públicas, havia uma hipótese de trabalho referente à aplicação de atividades pedagógicas de forma a justificar e ampliar a atividade de aplicação da OBMEP nas escolas, fazendose uma análise aprofundada da Matriz de Referência, suporte para elaboração dos itens, conjuntamente com o estudo dos distratores, construindo-se transposições didáticas que contribuíssem para o aprendizado dos estudantes brasileiros.

No entanto, ao se fazer as análises dos documentos existentes, o trabalho foi tomando a direção de revelar aos organizadores do evento a importância da Engenharia de Itens na construção de uma avaliação que mostre, com mais fidedignidade, o nível de seus participantes.

Embora o trabalho aqui desenvolvido tenha sido um estudo de caso, os resultados fornecem uma pista do desempenho dos estudantes, como um todo, neste certame. Além disso, a análise da construção do instrumento revela resultados mais robustos quando da conformidade com a Engenharia de Itens. Neste quesito, a banca elaboradora do certame encontrará parâmetros que podem contribuir para a reavaliação da metodologia de elaboração de avaliações que contemplem mais efetivamente seus objetivos, que incluem:

1. estimular e promover o estudo da Matemática entre alunos das escolas públicas, elaborando o instrumento de avaliação de primeira fase da OBMEP e contemplando itens em toda a escola de dificuldade;

2. contribuir para a melhoria da qualidade da educação básica, construindo os distratores dos itens de forma a possibilitar a análise do erro das marcações dos estudantes pelos professores;

3. identificar jovens talentos e incentivar seu ingresso nas áreas científicas e tecnológicas;

4. incentivar o aperfeiçoamento dos professores das escolas públicas, contribuindo para a sua valorização profissional, realizando estudos sobre a elaboração e uso de instrumentos de avaliação de forma a alcançar uma aprendizagem significativa;

5. contribuir para a integração das escolas públicas com as universidades públicas, os institutos de pesquisa e as sociedades científicas;

6. promover a inclusão social por meio da difusão do conhecimento. 


\section{Em relação a OBMEP}

Devido à relevância da OBMEP no ensino de Matemática no Brasil, e considerando os seus principais objetivos, cabe realizar algumas considerações em relação aos atores envolvidos nesse certame.

Aos elaboradores do certame cabe um estudo mais amplo e semelhante ao feito neste trabalho, no que tange à análise quantitativa, iniciando com o levantamento dos dados, determinando os índices da TCT e as AGIs dos itens, tomando-se como base provas futuras e uma amostra mais representativa da população. Isso deve ser feito para verificar se os instrumentos elaborados são constituídos de itens que realmente discriminam os sujeitos, já que o estudo revelou a predominância de índices de discriminação baixos, em todos os itens, de acordo com o que preceitua a literatura na área de avaliação. O mesmo ocorre com a distribuição de itens em relação à dificuldade em todo o teste.

Sugere-se também aos elaboradores, ao tomar ciência desta análise, elaborar uma matriz de referência para dar suporte ao processo de construção dos itens das provas futuras, de acordo com as orientações provenientes da teoria da medida para avaliação de larga escala e da Engenharia de Itens.

Recomenda-se a aplicação dos pressupostos da TRI na elaboração dos itens, pois isso possibilitaria a construção e interpretação de uma escala de proficiência, o que seria excelente feedback para escolas e estudantes participantes, e proporcionaria selecionar melhor os estudantes que participarão da fase seguinte. Além disso, o desempenho nessa fase da Olimpíada poderia ser uma informação complementar àquela obtida nas provas do SAEB e da Prova Brasil, no que diz respeito ao desempenho dos estudantes em Matemática.

Da mesma forma, para os gestores das escolas participantes, sugere-se que os resultados apresentados pelos alunos, no nível institucional, sejam utilizados como parâmetros de reflexão de cada instituição, de modo a inserir ações e metas no seu PPP, de forma a tornar a aprendizagem mais significativa para os estudantes, como, incluir projetos que minimizem as dificuldades inferidas a partir do desempenho dos estudantes.

Aos docentes, sugere-se que, ao criarem seus instrumentos avaliativos, utilizem este material de estudo como reflexão de sua prática pedagógica, e que utilizem a Engenharia de Itens na construção de testes e provas. Principalmente, que repensem a intencionalidade de um fazer avaliativo de qualidade, proporcionando uma reflexão ativa do seu estudante nos mais diversos instrumentos.

E ainda que, ao utilizarem um instrumento de avaliação de larga escala, explorem ao máximo os materiais propostos, não usando apenas como ferramenta de treinamento, mas como uma investigação dos erros apresentados, para que sejam realizadas atividades que deem significado aos conceitos aprendidos e reorientem as metas de aprendizagem 
individual dos alunos, contribuindo para seu auto-monitoramento.

Dessa forma, pretende-se que professores e alunos sejam atuantes no processo avaliativo, e que tornem a aplicação da prova da primeira fase da OBMEP um momento real de aprendizagem matemática na escola, atribuindo a este instrumento classificatório um caráter formativo.

Aos elaboradores de avaliação de larga escala ou não, sugere-se que estejam atentos a dar intencionalidade na construção dos distratores, para que os resultados das análises das marcações realizadas pelos estudantes contribuam de fato para o refazer pedagógico, em sala de aula, dos objetivos de aprendizagem. Isso pode ser feito descartando-se a enumeração consecutiva nas alternativas, eliminando os fatores de atração e utilizando a categorização de erros para elaborar os distratores, distribuídos nos eixos de categorização citados a seguir.

Assim, a categorização dos distratores poderá ser utilizada para traçar estratégias de intervenções pedagógicas, contribuindo para a melhoria da aprendizagem de matemática. Uma ação simples de repensar a construção do instrumento avaliativo, dando plausibilidade aos distratores e suporte aos docentes para realizar as análises dos mesmos, pode ampliar as propostas dos idealizadores da OBMEP de forma a contemplar a melhoria do ensino de Matemática nas escolas.

\section{Quanto à categorização}

Após a categorização dos erros inferidos, deve-se ter um olhar diferenciado frente aos mesmos diante das atividades tanto do elaborador quanto do docente. Assim foram construídas três tabelas-resumo com os itens, aqui estudados, enquadrados de acordo com as categorizações de Bodin (1997), Radatz (1979) e Casey (CLEMENTS, 1980 apud CURY, 2007), para melhor representar esta parte da pesquisa.

A partir dos dados apresentados nas Tabelas 14, 15 e 16, o elaborador de itens precisa considerar a categorização como um todo para construir os distratores previamente.

O item relacionado a erro devido à formulação da questão (Tabela 16) é, na verdade, uma notificação do que se deve abandonar na prática de construção de itens. Acrescenta-se a necessidade de se tomar o devido cuidado com os dados presentes no texto-base e nas alternativas.

Agora, com relação ao docente, a discussão sobre esses resultados já é mais extensa.

No tocante aos erros relacionados a saber, a dificuldade com a linguagem e ao domínio deficiente de conteúdos - Tabela 14 e 15, respectivamente - é necessário verificar a deficiência dos estudantes no que tange à modelagem algébrica, a conceitos geométricos de espaço e forma, a grandezas e medidas e à média aritmética. 
Tabela 14 - Erro diante à construção de conhecimento em uma situação didática de Matemática, segundo Bodin (1997)

\begin{tabular}{|c|c|c|c|}
\hline \multicolumn{2}{|c|}{ Erros relacionados a: } & \multirow{3}{*}{$\begin{array}{l}\text { Item } \\
\text { (Alternativa) } \\
7(\mathrm{E}) \\
8(\mathrm{E})\end{array}$} & \multirow{3}{*}{$\begin{array}{l}\text { Habilidades relacionadas a: } \\
\text { Grandezas proporcionais. } \\
\text { Medida de tendência central: média aritmé- } \\
\text { tica. }\end{array}$} \\
\hline & o aprendiz não tem & & \\
\hline Saber & $\begin{array}{l}\text { conhecimento matemático } \\
\text { sobre as definições, as regras, }\end{array}$ & & \\
\hline & os algoritmos, e outros & 15 (B e D) & Modelagem algébrica. \\
\hline & & 19 & $\begin{array}{l}\text { Conhecimentos geométricos de espaço e forma } \\
\text { e modelagem algébrica. }\end{array}$ \\
\hline \multirow{4}{*}{ Saber-fazer } & \multirow{4}{*}{$\begin{array}{l}\text { o aprendiz não tem domínio } \\
\text { da técnica de resolução, do } \\
\text { algoritmo, e outros }\end{array}$} & $3(\mathrm{C}$ e $\mathrm{E})$ & $\begin{array}{l}\text { Utilizar conhecimentos geométricos e proprie- } \\
\text { dades angulares de polígonos }\end{array}$ \\
\hline & & $11(\mathrm{~B}), 17$ & Raciocínio lógico a partir de deduções \\
\hline & & $14(\mathrm{~A}$ e $\mathrm{E})$ & $\begin{array}{l}\text { Raciocínio lógico a partir de deduções, aplica- } \\
\text { das a grandeza de tempo. }\end{array}$ \\
\hline & & $18(\mathrm{~A}$ e $\mathrm{B})$ & Contagem e principio multiplicativo. \\
\hline \multirow{7}{*}{$\begin{array}{l}\text { Utilização } \\
\text { adequada } \\
\text { ou não dos } \\
\text { saberes ou } \\
\text { do } \\
\text { saber-fazer }\end{array}$} & \multirow{7}{*}{$\begin{array}{l}\text { o aprendiz não reconhece o } \\
\text { conceito correto para aplicar } \\
\text { na resolução de uma } \\
\text { situação-problema }\end{array}$} & $3(\mathrm{C}$ e $\mathrm{E})$ & $\begin{array}{l}\text { Utilizar conhecimentos geométricos e proprie- } \\
\text { dades angulares de polígonos }\end{array}$ \\
\hline & & $4(\mathrm{~A})$ & $\begin{array}{l}\text { Identificar padrões numéricos e operações com } \\
\text { numero inteiros. }\end{array}$ \\
\hline & & $5(\mathrm{~B})$ & $\begin{array}{l}\text { Conhecimentos geométricos de grandezas e } \\
\text { medidas. }\end{array}$ \\
\hline & & $9(\mathrm{~A}$ e $\mathrm{D})$ & Razão entre áreas de figuras planas. \\
\hline & & 10 & Variações de grandezas proporcionais. \\
\hline & & 14(B e D) & $\begin{array}{l}\text { Raciocínio lógico a partir de deduções, aplica- } \\
\text { das a grandeza de tempo. }\end{array}$ \\
\hline & & $18(\mathrm{C}$ e $\mathrm{D})$ & Contagem e principio multiplicativo. \\
\hline \multirow{13}{*}{$\begin{array}{l}\text { Lógica ou } \\
\text { de } \\
\text { raciocínio }\end{array}$} & \multirow{13}{*}{$\begin{array}{l}\text { o aprendiz confunde hipótese } \\
\text { e tese, encadeia mal os } \\
\text { cálculos, não sabe lidar com } \\
\text { os dados apresentados }\end{array}$} & $1(\mathrm{~A})$ & Termo central de sequência numérica. \\
\hline & & $2(\mathrm{C})$ & $\begin{array}{l}\text { Decomposição em fatores primos. Valor posi- } \\
\text { cional. }\end{array}$ \\
\hline & & $4(\mathrm{~A}$ e $\mathrm{C})$ & $\begin{array}{l}\text { Identificar padrões numéricos e operações com } \\
\text { numero inteiros. }\end{array}$ \\
\hline & & $5(\mathrm{~B})$ & $\begin{array}{l}\text { Conhecimentos geométricos de grandezas e } \\
\text { medidas. }\end{array}$ \\
\hline & & 6 & Raciocínio lógico a partir de deduções \\
\hline & & 8 & Posição no plano cartesiano. \\
\hline & & 11(B e E), 17 (B e D) & Raciocínio lógico a partir de deduções \\
\hline & & $13(\mathrm{C})$ & $\begin{array}{l}\text { Resolver situações-problema com numero na- } \\
\text { turais, valores posicionais. }\end{array}$ \\
\hline & & $14(\mathrm{~B}$ e $\mathrm{D})$ & $\begin{array}{l}\text { Raciocínio lógico a partir de deduções, aplica- } \\
\text { das a grandeza de tempo. }\end{array}$ \\
\hline & & $15(\mathrm{~B}$ e $\mathrm{D})$ & Modelagem algébrica. \\
\hline & & $16(\mathrm{~A}$ e $\mathrm{E})$ & $\begin{array}{l}\text { Raciocínio lógico a partir de deduções e maxi- } \\
\text { mização }\end{array}$ \\
\hline & & 18 & Contagem e principio multiplicativo. \\
\hline & & $20(\mathrm{C})$ & $\begin{array}{l}\text { Identificar regularidades observada em se- } \\
\text { quencia de números naturais. }\end{array}$ \\
\hline
\end{tabular}

Neste eixo, o conteúdo é o foco da intervenção do professor. Conceitos que devem ser retomados com uma postura de ressignificar o que no foi aprendido. Até mesmo, retomando seu estudo durante todo o processo de aprendizagem, após a realização do certame, pois são conceitos que embasam todo o ensino de Matemática após o nono ano. Este eixo poderia ser chamado de eixo de erros conceituais, quando cabe ao professor uma interferência no currículo de forma a trabalhar novamente os conceitos aqui especificados.

Quanto aos erros relacionados a saber-fazer, a utilização adequada dos saberes ou do saber-fazer (Tabela 14); as associações incorretas ou rigidez de pensamento, a aplicação de regras ou estratégias irrelevantes (Tabela 15), a seleção de estratégias, a manipulação das habilidades e a apresentação da solução (Tabela 16), o qual poderia ser chamado 
Tabela 15 - Erros de acordo com um modelo embasado nos mecanismos do processamento de informação, segundo Radatz (1979)

\begin{tabular}{|c|c|c|c|}
\hline \multicolumn{2}{|c|}{ Erros relacionados a: } & \multirow{2}{*}{$\begin{array}{l}\begin{array}{l}\text { Item } \\
\text { (Alternativa) }\end{array} \\
19\end{array}$} & \multirow{2}{*}{$\begin{array}{l}\text { Habilidades relacionadas aos itens } \\
\text { Conhecimentos geométricos de espaço e forma e } \\
\text { modelagem algébrica. }\end{array}$} \\
\hline $\begin{array}{l}\text { a dificuldade de } \\
\text { linguagem }\end{array}$ & $\begin{array}{l}\text { relacionado ao formalismo sim- } \\
\text { bólico }\end{array}$ & & \\
\hline \multirow{4}{*}{$\begin{array}{l}\text { a dificuldade } \\
\text { de obter } \\
\text { informação } \\
\text { espacial }\end{array}$} & \multirow{4}{*}{$\begin{array}{l}\text { relacionado à falta de } \\
\text { capacidade de visualização de } \\
\text { diagramas, figuras, "instruções } \\
\text { icônicas" }\end{array}$} & $5(\mathrm{~B})$ & $\begin{array}{l}\text { Conhecimentos geométricos de grandezas e me- } \\
\text { didas. }\end{array}$ \\
\hline & & 8 & Posição no plano cartesiano. \\
\hline & & 11(B) & Raciocínio lógico a partir de deduções \\
\hline & & 19 & $\begin{array}{l}\text { Conhecimentos geométricos de espaço e forma e } \\
\text { modelagem algébrica. }\end{array}$ \\
\hline \multirow{4}{*}{$\begin{array}{l}\text { ao domínio } \\
\text { deficiente de } \\
\text { conteúdos, } \\
\text { fatos e } \\
\text { habilidades }\end{array}$} & \multirow{4}{*}{$\begin{array}{l}\text { consideradas como } \\
\text { pré-requisitos }\end{array}$} & $9(\mathrm{~A}$ e $\mathrm{D})$ & Razão entre áreas de figuras planas. \\
\hline & & $15(\mathrm{~B}$ e $\mathrm{D})$ & Modelagem algébrica. \\
\hline & & 19 & $\begin{array}{l}\text { Conhecimentos geométricos de espaço e forma e } \\
\text { modelagem algébrica. }\end{array}$ \\
\hline & & $2(\mathrm{C})$ & $\begin{array}{l}\text { Decomposição em fatores primos. Valor posicio- } \\
\text { nal. }\end{array}$ \\
\hline \multirow{8}{*}{$\begin{array}{l}\text { a associações } \\
\text { incorretas ou } \\
\text { rigidez de } \\
\text { pensamento }\end{array}$} & \multirow{8}{*}{$\begin{array}{l}\text { tanto conceitual anterior } \\
\text { quanto no uso de uma regra a } \\
\text { caso específico }\end{array}$} & $3(\mathrm{C}$ e $\mathrm{E})$ & $\begin{array}{l}\text { Utilizar conhecimentos geométricos e proprieda- } \\
\text { des angulares de polígonos }\end{array}$ \\
\hline & & $9(\mathrm{~A}$ e $\mathrm{D})$ & Razão entre áreas de figuras planas. \\
\hline & & 11(B e E), 17 & Raciocínio lógico a partir de deduções \\
\hline & & $13(\mathrm{C})$ & $\begin{array}{l}\text { Resolver situações-problema com numero natu- } \\
\text { rais, valores posicionais. }\end{array}$ \\
\hline & & $14(\mathrm{~B}$ e $\mathrm{D})$ & $\begin{array}{l}\text { Raciocínio lógico a partir de deduções, aplicadas } \\
\text { a grandeza de tempo. }\end{array}$ \\
\hline & & $16(\mathrm{~A}$ e $\mathrm{E})$ & $\begin{array}{l}\text { Raciocínio lógico a partir de deduções e maximi- } \\
\text { zação }\end{array}$ \\
\hline & & $18(\mathrm{~A}$ e $\mathrm{B})$ & Contagem e principio multiplicativo. \\
\hline & & $20(\mathrm{~A})$ & $\begin{array}{l}\text { Identificar regularidades observada em sequencia } \\
\text { de números naturais. }\end{array}$ \\
\hline \multirow{11}{*}{$\begin{array}{l}\text { a aplicações de } \\
\text { regras ou } \\
\text { estratégias } \\
\text { irrelevantes }\end{array}$} & \multirow{11}{*}{$\begin{array}{l}\text { o uso inadequado de } \\
\text { estratégias de solução }\end{array}$} & $1(\mathrm{~A})$ & Termo central de sequência numérica. \\
\hline & & $3(\mathrm{C}$ e $\mathrm{E})$ & $\begin{array}{l}\text { Utilizar conhecimentos geométricos e proprieda- } \\
\text { des angulares de polígonos }\end{array}$ \\
\hline & & $4(\mathrm{~A}$ e $\mathrm{C})$ & $\begin{array}{l}\text { Identificar padrões numéricos e operações com } \\
\text { numero inteiros. }\end{array}$ \\
\hline & & $5(\mathrm{~B})$ & $\begin{array}{l}\text { Utilizar conhecimentos geométricos e proprieda- } \\
\text { des angulares de polígonos }\end{array}$ \\
\hline & & 8 & Posição no plano cartesiano. \\
\hline & & $9(\mathrm{~A}$ e $\mathrm{D})$ & Razão entre áreas de figuras planas. \\
\hline & & 10 & Variações de grandezas proporcionais. \\
\hline & & $14(\mathrm{~A}$ e $\mathrm{E})$ & $\begin{array}{l}\text { Raciocínio lógico a partir de deduções, aplicadas } \\
\text { a grandeza de tempo. }\end{array}$ \\
\hline & & 15 (B e D) & Modelagem algébrica. \\
\hline & & $16(\mathrm{~B})$ & $\begin{array}{l}\text { Raciocínio lógico a partir de deduções e maximi- } \\
\text { zação }\end{array}$ \\
\hline & & $18(\mathrm{C}$ e $\mathrm{D})$ & Contagem e principio multiplicativo. \\
\hline
\end{tabular}

de eixo prático-teórico. São erros relacionados à atitude do aluno diante da resolução de situações proposta. Neste eixo prático-teórico, houve erros relacionados a todas as habilidades inferidas no estudo, mostrando a fragilidade frente à tomada de decisão em usar os conhecimentos aprendidos por parte dos estudantes.

O aluno é foco de trabalho neste eixo, no qual recomendado-se ao professor uma intervenção individualizada, apresentando o que se esperava do aluno frente aos itens e motivar a tomada de iniciativa do aluno em sanar tais erros. O professor pode distribuir os alunos em grupo e sugerir um trabalho de correção pelos pares, discutindo abertamente quais os erros apresentados ou até mesmo numa conversa individualizada. Pode também realizar atividades após a tomada de consciência do erro, para verificar se após 
Tabela 16 - As causas dos erros, segundo Casey (CLEMENTS, 1980 apud CURY, 2007)

\begin{tabular}{|c|c|c|}
\hline Erros relacionados a: & Item (Alternativa) & Observações \\
\hline \multirow{7}{*}{$\begin{array}{l}\text { formulação da } \\
\text { questão }\end{array}$} & $2(\mathrm{E})$ & Exemplo apresentado no texto-base. \\
\hline & $4(\mathrm{E})$ & Fator de atração: número presente no comando do item. \\
\hline & $5(\mathrm{C})$ & $\begin{array}{l}\text { Fator de atração: resultado aparece no meio do processo de } \\
\text { resolução. }\end{array}$ \\
\hline & $5(\mathrm{~A}), 7(\mathrm{~A})$ & $\begin{array}{l}\text { Resultado correto obtido por processo errôneo de interpre- } \\
\text { tação }\end{array}$ \\
\hline & $\begin{array}{l}9(\mathrm{C}), 10(\mathrm{~A} \text { e } \mathrm{B}), 17(\mathrm{~A}) \\
18(\mathrm{~A})\end{array}$ & Fator de atração: formato diferenciado das alternativas \\
\hline & 10 & Apresentação de dado irrelevante. \\
\hline & $12(\mathrm{~A}), 17(\mathrm{~A})$ & Fator de atração: soma de dados do texto-base. \\
\hline leitura & $1(\mathrm{~A}), 4(\mathrm{~A}$ e $\mathrm{C}), 5(\mathrm{D}), 17$ & \\
\hline compreensão & $\begin{array}{l}1(\mathrm{~A}), 4(\mathrm{~A} \text { e } \mathrm{C}), \quad 5(\mathrm{D}), \\
10,11(\mathrm{~A} \text { e } \mathrm{E}), 12(\mathrm{~A}), 15, \\
16(\mathrm{E}), 17,18,20(\mathrm{~A} \text { e } \mathrm{C})\end{array}$ & \\
\hline seleção de estratégias & $\begin{array}{l}\text { 1(A), } 3(\mathrm{C} \text { e } \mathrm{E}), 5(\mathrm{D}), 10 \\
13,15,16(\mathrm{~B} \text { e } \mathrm{E}), 17,18 \\
20(\mathrm{~A} \text { e C) }\end{array}$ & \\
\hline $\begin{array}{l}\text { manipulação das habilida- } \\
\text { des }\end{array}$ & $1(\mathrm{~A}), 2(\mathrm{C}), 3(\mathrm{C}$ e $\mathrm{E})$ & \\
\hline apresentação da solução & $\begin{array}{l}1(\mathrm{~A}), 5(\mathrm{C}), 11(\mathrm{E}), 12(\mathrm{~B}) \\
13,18,20(\mathrm{~A} \mathrm{e} \mathrm{C})\end{array}$ & \\
\hline
\end{tabular}

o enfrentamento houveram melhoras.

Os erros relacionados com a dificuldade de obter informação espacial (Tabela 15), leitura e compreensão (Tabela 16), podem ser resumidos em um eixo intitulado textobase, no qual a ação do professor com relação a interpretação de textos e figuras ligadas a conceitos matemáticos presentes em situações-problema, avaliativas ou não. Este eixo não é apenas matemático, mas ligado a linguagem escrita e sua compreensão.

É necessário apresentar estas dificuldades na realização dos itens para toda a equipe escolar, objetivando uma intervenção com projetos interdisciplinares, para dar mais amplitude na visão e na interpretação do aluno dos mais diferentes conceitos, a partir da linguagem escrita. Dando significado ao dia de aplicação da OBMEP na escola.

Por fim, o eixo de aprendizagem a partir dos erros em lógica ou de raciocínio, que denota a maturidade do raciocínio lógico dedutivo do aluno. Para se ter uma intervenção significativa, pressupõe-se que os eixos anteriores devam ser bem trabalhados, para depois se montar atividades que evidenciem questionamentos lógicos aos alunos.

E finalmente, aos estudantes, sugere-se que tomem seus resultados nesta olimpíada como o início de uma caminhada em busca da aprendizagem matemática de forma permanente, contribuindo para desenvolver suas capacidades de crítica, argumentação e raciocínio. 


\section{Trabalhos futuros}

Frente a essas considerações, vê-se a relevância deste estudo e de sua continuidade no sentido de embasar a formação de docentes, em todas as esferas de ensino. Da mesma forma, objetiva-se contribuir para a formação dos elaboradores de avaliação de larga escala.

No entanto este estudo não se finaliza aqui, ainda há outro material de estudo desta amostra. Os resultados de desempenho a partir da TRI, que podem ajudar a desenviesar os resultados apresentados, serão usados a posteriori como continuação desta pesquisa. Falta ainda realizar o feedback deste estudo para as escolas investigadas, e acompanhamento de resultados futuros a partir da mobilização dos profissionais de tais instituições, de forma a sanar os obstáculos apresentados pelos estudantes na realização desta edição da OBMEP, ampliando-se o que está explícito no slogan da Olimpíada: SOMAR TALENTOS E RESSIGNIFICAR APRENDIZAGENS. 


\section{Referências}

ABRANTES, P. Avaliação e Educação Matemática. Rio de Janeiro: GEPEM, 1995. Citado na página 52.

BARBOSA, J. L. M. Olimpíadas de Matemática: uma experiência de sucesso em educação no Ceará. 2014. < http://www.sbpcnet.org.br/livro/57ra/programas/CONF_SIMP/ textos/joaolucasbarbosa-simp.htm>. Acesso: 04/12/2014. Citado na página 37.

BARDIN, L. Análise de conteúdo. Lisboa: Edições 70, 2011. Citado 5 vezes nas páginas 83, 84, 85, 107 e 108.

BARICHELlO, L. Análise de Resolução de Problemas de Cálculo Diferencial em um Ambiente de Interação Escrita. Dissertação (Mestrado) — Universidade Estadual Paulista/IGCE, São Paulo, 2008. Citado 2 vezes nas páginas 89 e 90.

BELLOS, A. Educação Crítica: incerteza, matemática, responsabilidade. São Paulo: Cortez, 2007. Citado na página 37.

BELlOS, A. Alex no País dos Números - Uma viagem ao mundo maravilhoso da Matemática. São Paulo: Companhia das Letras, 2011. Citado 2 vezes nas páginas 31 e 32.

BODIN, A. L'evaluation du savoir mathématique. Paris: mimeo, 1997. Citado 19 vezes nas páginas 17, 96, 119, 121, 130, 131, 133, 134, 137, 139, 141, 144, 147, 149, 151, 153, 155,163 e 164.

BORASI, R. Reconceiving mathematics Instruction: a Focus on Erros. Norwood, NJ: Ablex Publishing Corporation, 1996. Citado 2 vezes nas páginas 88 e 99.

BRASIL. Parâmetros Curriculares Nacionais. Matemática: ensino de quinta à oitava série. Brasília: Secretaria de Educação Fundamental, 2000. Citado 5 vezes nas páginas 49, $51,52,55$ e 96.

BRASIL. Caderno AVA 2000 - Matemática: Uma Análise Pedagógica. Curitiba: Secretaria de Estado de Educação, 2001. Citado na página 101.

BURIASCO, L. C. Sobre a avaliação em matemática: Uma reflexão. Educação em Revista, Belo Horizonte, v. 36, p. 255 - 263, dez. 2002. Citado na página 53.

BURIASCO, L. C.; SOARES, M. T. C. Avaliação de sistemas escolares: da classificação dos alunos à perspectiva de análise de sua produção matemática. In: (ORG), W. R. V. (Ed.). Avaliação em Matemática: História e Perspectivas Atuais. [S.l.]: Papirus, 2012. p. 101 - 140. Citado na página 53.

BURIASCO, R. L. C. Algumas considerações sobre avaliação educacional. In: Estudos em Avaliação Educacional. São Paulo: [s.n.], 2000. v. 1, n. 22, p. 175 - 178. Citado 2 vezes nas páginas 96 e 100.

BURIASCO, R. L. C. de; FERREIRA, P. E. A.; CIANI, A. B. Avaliação como prática de investigação. BOLEMA, v. 22, n. 33, p. 69 - 96, 2009. Citado 2 vezes nas páginas 23 e 25 . 
CLEMENTS, M. A. K. Analyzing children's errors on written mathematical tasks. In: Educational Studies in Mathematics. [S.l.: s.n.], 1980. v. 11, n. 1, p. $1-21$. Citado 17 vezes nas páginas 17, 98, 119, 121, 137, 139, 141, 143, 144, 147, 149, 151, 153, 155, 159, 163 e 166.

CONDé, F. N. Análise empírica de itens. [S.l.], 2001. Citado na página 62.

CONDé, F. N. Relação entre Características do Teste Educacional e Estimativa de Habilidade do Estudante. Brasília: UnB, 2008. Citado 2 vezes nas páginas 61 e 64.

CORREIA, C. E. F. Matemática, Análise de Erros e Formação Continuada de Professores Polivalentes. São Paulo: Porto de Ideias, 2010. Citado na página 55.

CORREIA, C. E. F. Matemática, análise de erros e formação continuada de professores polivalentes. São Paulo: Porto de ideais, 2010. Citado 6 vezes nas páginas 89, 90, 91, 92, 93 e 94.

CURY, H. N. Análise de erros e análise de conteúdo: subsídios para uma proposta metodológica. In: Seminário Internacional de Pesquisa em Educação Matemática. [S.l.: s.n.], 2003. v. 2. Citado 3 vezes nas páginas 83, 85 e 90.

CURY, H. N. Análise de erros: o que podemos aprender com as respostas dos alunos. Belo Horizonte: Editora Autência, 2007. Citado 21 vezes nas páginas 17, 88, 94, 97, 98, 99, 119, 121, 137, 139, 141, 143, 144, 147, 149, 151, 153, 155, 159, 163 e 166.

ESTEBAN, M. T. Ser professora: avaliar e ser avaliada. In: ESTEBAN, M. T. (Ed.). Escola, currículo e avaliação. São Paulo: Cortez, 2003. p. 13 - 37. Citado na página 25.

FLETCHER, P. R. Da Teoria Clássica dos Testes para os Modelos de Resposta ao Item. Rio de Janeiro: Escola Nacional de Ciências, 2010. Citado na página 61.

FREITAS, L. C. Crítica e Organização do Trabalho Pedagógico e da Didática. São Paulo: Papirus, 1995. Citado 2 vezes nas páginas 46 e 47.

FREITAS, L. C. Avalição Educacional: Caminhando Pela Contramão. Rio de Janeiro: Ed. Petrópolis, 2014. Citado 3 vezes nas páginas 49, 50 e 102.

FREITAS, L. C. de. A internalização da exclusão. Educação $\&$ Sociedade, v. 23, n. 80, p. $301-327$, set. 2002. Citado na página 48.

HADJI, C. Avaliação Desmistificada. Porto Alegre: Artmed, 2001. Citado na página 48.

IMO. 2014. <http://www.imo-official.org>. Acesso: 14/12/2014. Citado 2 vezes nas páginas 32 e 33.

IMPA; SBM. OBMEP Regulamento. 2014. < http://www.obmep.org.br/regulamento. html>. Acesso: 14/12/2014. Citado na página 38.

IMPA; SBM. OBMEP. Sítio Oficial. 2014. <http://www.obmep.org.br>. Acesso: 14/12/2014. Citado na página 41.

MACEDO, L. de. Ensaios Construtivistas. São Paulo: Casa do Psicólogo, 1994. Citado na página 92. 
MACIEL, M. V. M. Olimpíada brasileira de matemática das escolas públicas (obmep): as origens de um projeto de qualificação do ensino de matemática na educação básica. In: Anais do Encontro Gaúcho de Educação Matemática. Ijuí, RS: [s.n.], 2009. Citado 3 vezes nas páginas 32, 37 e 42.

MARANHãO, T. de P. A. Avaliação do Impacto da Olimpíada Brasileira de Matemática nas Escolas Públicas 2010. Brasília: Centro de Gestão e Estudos Estratégicos, 2011. Citado na página 31.

MINAYO, M. C. de S. O desafio do conhecimento: pesquisa qualitativa em saúde. São Paulo: Hucitec, 2000. Citado 2 vezes nas páginas 83 e 84.

MORAES, R. Análise de conteúdo. In: Educação. Porto Alegre: [s.n.], 1999. v. 22, n. 37. Citado na página 85.

OBM. Sítio Oficial. 2014. <http://obm.org>. Acesso: 14/12/2014. Citado 2 vezes nas páginas 17 e 35.

OBM. Sítio Oficial. Brasileiro Ganha Medalha Fields. 2014. <http://obm.org/opencms/ fique_por_dentro/novidades/novidade_0038.hmtl>. Acesso: 14/12/2014. Citado na página 36 .

OBMEP. OBMEP na Escola. 2015. < http://www.obmep.org.br/OBMEP_na_escola. html>. Acesso: 24/03/2015. Citado na página 41.

OCED. Relatório Nacional PISA 2012. 2014. < http://download.inep.gov.br/acoes_ internacionais/pisa/resultados/2014/relatorio_nacional_pisa_2012_resultados_ brasileiros.pdf>. Acesso: 05/12/2014. Citado na página 42.

PASQUALI, L. Psicometria: Teoria e Aplicações. Brasília: Editora UnB, 1997. Citado na página 63.

PERRENOUD, P. A prática reflexiva no ofício de professor: profissionalização e razão pedagógica. Porto Alegre: Artmed, 2002. Citado na página 72.

PIAGET, J. Seis estudos de psicologia. São Paulo: Forense Universitária, 1991. Citado na página 93.

PINTO, N. B. O erro como estratégia didática: Estudo do erro no ensino da matemática elementar. Campinas: Papirus, 2000. Citado 3 vezes nas páginas 89, 92 e 101.

QEDU. Sítio Oficial. 2014. <http://www.qedu.org.br>. Acesso: 14/12/2014. Citado na página 43.

RABELO, M. Avaliação educacional: fundamentos, metodologia e aplicações no contexto brasileiro. Rio de Janeiro: SBM, 2013. Citado 23 vezes nas páginas 15, 17, 25, 59, 60, 62, 63, 64, 67, 68, 69, 72, 73, 74, 77, 78, 81, 87, 112, 113, 114, 121 e 123.

RADATZ, H. Errors analysis in mathematics education. In: Journal for Research in Mathematics Education. [S.l.: s.n.], 1979. v. 10, n. 3, p. 163 - 72 . Citado 18 vezes nas páginas 17, 97, 99, 119, 121, 130, 134, 137, 139, 141, 144, 147, 149, 151, 153, 155, 163 e 165. 
RICO, L. Errores y dificuldades em el aprendizaje de lãs matemática. In: KIPRATICK, J.; GOMES, P.; RICO, L. (Ed.). Educación matemática. Colômbia: Grupo editorial iberoamérica, 1995. p. 69 - 108. Citado 2 vezes nas páginas 90 e 91.

RODRIGUES, M. M. Proposta de análise de itens das provas do saeb sob a perspetiva pedagógica e a psicométrica. In: Estudos em Avaliação Educacional. [S.l.: s.n.], 2006. v. 17, n. 34. Citado 7 vezes nas páginas 15, 61, 62, 64, 65, 66 e 116.

ROSSO, A. J.; BERTI, N. M. O erro e o ensino-aprendizagem de matemática na perspectiva do desenvolvimento da autonomia do aluno. In: Boletim de Educação Matemática UNESP. [S.l.: s.n.], 2010. v. 23, p. 1005 - 1035. Citado 2 vezes nas páginas 94 e 100.

SADLER, R. Formative assessment and the design of instructional systems. Instructional Science, v. 18, p. 119 - 144, jun. 1989. Citado 2 vezes nas páginas 46 e 47.

SANTOS, J. R. V. dos. O que alunos da escola básica mostram saber por meio de sua produção escrita em matemática. Dissertação (Mestrado) — Universidade Estadual de Londrina, 2007. Citado na página 25.

SCHIRLO, A. C.; MEZA, E. dos S. Obmep: Projeto de política pública para a inclusão social de estudantes com talento em matemática. In: Anais do XI Encontro Nacional de Educação Matemática.XI Encontro Nacional de Educação Matemática. Curitiba, PR: [s.n.], 2013. Citado 2 vezes nas páginas 37 e 38.

SILVA, M. C. N.; BURIASCO, R. L. C. Análise da produção escrita em matemática: Algumas considerações. In: Ciência e Educação. [S.l.: s.n.], 2005. v. 11, n. 3, p. 499 - 512. Citado 5 vezes nas páginas 87, 88, 89, 92 e 101.

SKOVSMOSE, O. Educação Matemática Crítica: a questão da democracia. 2. ed. Campinas: Papirus, 2004. Citado na página 42.

TAILLE, Y. de L. O erro na perspectiva piagetiana. In: AQUINO, J. G. (Ed.). Erro e fracasso na escola: alternativas teóricas e práticas. São Paulo: Summus, 1997. p. 25 - 44. Citado na página 94.

TEIXEIRA, L. R. Análise de erros: Uma perspectiva cognitiva para compreender o processo de aprendizagem de conteúdos matemáticos. In: Nuances. [S.l.: s.n.], 1997. v. 2. Citado 3 vezes nas páginas 92, 95 e 96.

TRIVIñOS, A. N. S. Introdução à pesquisa em ciências sociais: a pesquisa qualitativa em educação. São Paulo: Atlas, 1987. Citado na página 85.

VASCONCELLOS, C. Avaliação: concepção dialética libertadora do processo de avaliação escolar. 17. ed. São Paulo: Libertad, 2005. Citado na página 105.

VASCONCELLOS, C. do S. Avaliação da aprendizagem: práticas de mudança. São Paulo: Libertad, 1998. Citado 2 vezes nas páginas 53 e 54.

VILLAS-BOAS, B. M. de F. Avaliação formativa e formação de professores: Ainda um desafio. In: . Linhas Críticas. Brasília: [s.n.], 2006. v. 12, n. 22, p. 75 - 90. Citado 4 vezes nas páginas 24, 25, 46 e 47 .

VILLAS-BOAS, B. M. de F. Virando a Escola ao Avesso por Meio da Avaliação. São Paulo: Papirus, 2014. Citado 7 vezes nas páginas 46, 47, 48, 49, 51, 56 e 57. 
Apêndices 

APÊNDICE A - Termo de Consentimento 


\section{TERMO DE CONSENTIMENTO LIVRE E ESCLARECIDO}

Prezado(a) participante:

Sou estudante do curso de pós-graduação do programa PROFMAT - Mestrado Profissional em Matemática, do Departamento de Matemática da Universidade de Brasília. Estou realizando uma pesquisa sob supervisão do professor Mauro Luiz Rabelo, cujo objetivo é: Analisar os itens e as respostas dos estudantes do $8^{\circ}$ e $9^{\circ}$ ano do ensino fundamental às provas da OBMEP como meio para oferecer subsídios para a prática docente de professores de matemática. .

Sua participação envolve ceder o uso dos gabaritos respondidos pelos estudantes do $\underline{8^{\circ} \text { e } 9^{\circ} \text { ano do ensino fundamental às provas da OBMEP de } 2014 \text { e possibilitar a divulgação do }}$ resultado da pesquisa e as propostas de ação ao grupo de docentes.

A participação nesse estudo é voluntária e se você decidir não participar ou quiser desistir de continuar em qualquer momento, tem absoluta liberdade de fazê-lo.

Na publicação dos resultados desta pesquisa, sua identidade será mantida no mais rigoroso sigilo. Serão omitidas todas as informações que permitam identificá-lo, identificar a escola e/ou identificar os estudantes em estudo.

Mesmo não tendo benefícios diretos em participar, indiretamente você estará contribuindo para a compreensão do fenômeno estudado e para a produção de conhecimento científico.

Quaisquer dúvidas relativas à pesquisa poderão ser esclarecidas pelo pesquisador Regiane Quezia Gomes da Costa por telefone 92685976 ou por e-mail regianegomez@gmail.com.

\section{Atenciosamente}

Nome e assinatura do(a) estudante

Local e data

Nome e assinatura do professor orientador

Consinto em participar deste estudo e declaro ter recebido uma cópia deste termo de consentimento. 
APÊNDICE B - Requerimento CEBRASPE 


\section{Requerimento}

Somos estudantes do curso de pós-graduação do programa PROFMAT - Mestrado Profissional em Matemática, do Departamento de Matemática da Universidade de Brasília. Estamos realizando dois estudos sob supervisão do professor Mauro Luiz Rabelo. O material de estudo são as avaliações da primeira fase da OBMEP 2014, nível 2, de escolas do Distrito Federal .

Viemos requerer junto a Centro Brasileiro de Pesquisa em Avaliação e Seleção e de Promoção de Eventos - CEBRASPE para que elabore, a partir dos dados em anexo, os seguintes documentos:

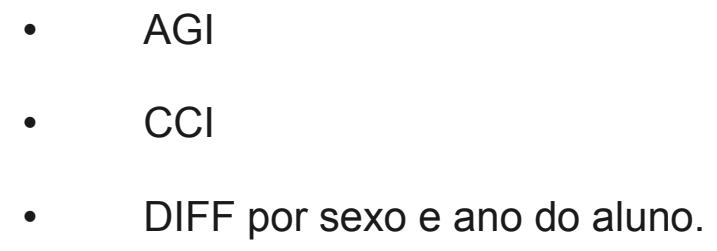

Desde já agradecemos pela contribuição.

Quaisquer dúvidas relativas à pesquisa poderão ser esclarecidas pelas pesquisadoras:

Ana Paula Lima Vilarinho, e-mail: anaplvilarinho@gmail.com ou Regiane Quezia Gomes da Costa, e-mail regianegomez@gmail.com. autoras dos respectivos estudos.

Atenciosamente

Ana Paula Lima Vilarinho

Regiane Quezia Gomes da Costa

Professor orientador

Local e data 
APÊNDICE C - Atividade Extra 
Não é necessário se identificar.

Professor(a):

Aluno(a):

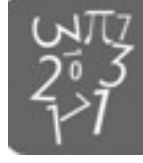

Olimpíada Brasileira de Matemática

Das escolas públicas

OBMEP 2014

$N^{\circ}$ :

Turma:

Data:

\section{Preparação para Olimpíada Brasileira de Matemática 2014 Somando Novos Talentos para o Brasil.}

É com grande alegria que contamos com sua participação, de seus professores e de sua escola na realização desta atividade. Encare as questões desta prova como quebra-cabeças interessantes e divirta-se com a busca de suas soluções. Em folha em anexo coloque as suas soluções de forma organizada numerando de acordo com as questões respondidas.

Grata pela sua participação.

3. Na figura, os pontos $A, B$ e $C$ estão alinhados. Qual é a soma dos ângulos marcados em cinza?
A) $120^{\circ}$
B) $180^{\circ}$
C) $270^{\circ}$
D) $360^{\circ}$
E) $540^{\circ}$

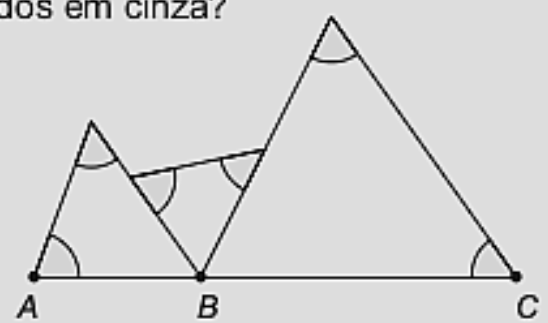

4. A sequência $-6,12,-18,24,-30,36, \ldots$ é obtida a partir dos múltiplos positivos de 6 , multiplicando-se os termos nas posições ímpares por -1 . Observe na figura que a soma dos dois primeiros termos da sequência é igual a 6 e a soma dos três primeiros termos é igual a -12 . Quantos termos consecutivos dessa sequência devemos somar, a partir do primeiro, para obter 180 como resultado?
A) 30
B) 60
C) 90
D) 120
E) 180

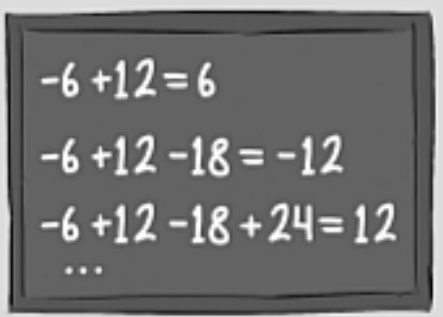

5. Os irmãos Luiz e Lúcio compraram um terreno cercado por um muro de 340 metros. Eles construíram um muro interno para dividir o terreno em duas partes. A parte de Luiz ficou cercada por um muro de 260 metros e a de Lúcio, por um muro de 240 metros. Qual é o comprimento do muro interno?
A) $80 \mathrm{~m}$
B) $100 \mathrm{~m}$
C) $160 \mathrm{~m}$
D) $180 \mathrm{~m}$
E) $200 \mathrm{~m}$

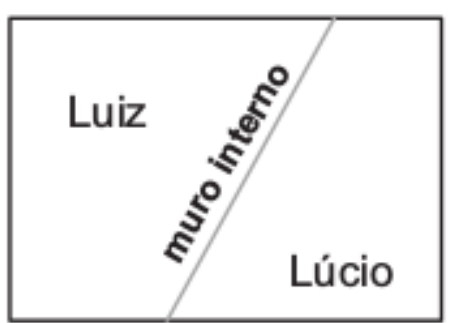


10. Sempre que Yurika abastece seu carro, ela enche o tanque e anota a data, a quilometragem marcada no painel e a quantidade de litros de combustível colocada. $\mathrm{Na}$ tabela estão os dados registrados por Yurika em dois abastecimentos consecutivos. Quantos quilômetros por litro, aproximadamente, fez o carro de Yurika nesse período?
A) 5,6
B) 9,8
C) 11,1
D) 12,9
E) 40,1

\begin{tabular}{|c|c|c|}
\hline data & $\mathrm{km}$ & litros \\
\hline$\vdots$ & $\vdots$ & $\vdots$ \\
\hline $01 / 02$ & 35723 & 32,5 \\
\hline $07 / 02$ & 36144 & 43,0 \\
\hline$\vdots$ & $\vdots$ & $\vdots$ \\
\hline
\end{tabular}

14. Rosane percebeu que seu antigo relógio de parede tinha parado às 9 horas. Ela deu corda no relógio, colocando-o para funcionar sem acertar o horário, e foi imediatamente ao mercado. Chegou ao mercado às 10 horas e 10 minutos. Fez suas compras em 1 hora e voltou para casa. Entrando em casa, notou que o relógio de parede marcava 10 horas e 40 minutos. Se Rosane realizou os percursos de ida e volta ao mercado em tempos iguais, a que horas ela entrou em casa?
A) 10 horas e 50 minutos
B) 11 horas e 10 minutos
C) 11 horas e 30 minutos
D) 11 horas e 40 minutos
E) 11 horas e 50 minutos

17. Gustavo possui certa quantidade de moedas de 1, 10, 25 e 50 centavos, tendo pelo menos uma de cada valor. É impossível combiná-las de modo a obter exatamente 1 real. Qual é o maior valor total possível para suas moedas?
A) 86 centavos
B) 1 real e 14 centavos
C) 1 real e 19 centavos
D) 1 real e 24 centavos
E) 1 real e 79 centavos

Atividade realizada para estudo de itens e resoluções da OBMEP para estudo pós-graduação do programa PROFMAT - Mestrado Profissional em Matemática, do Departamento de Matemática da Universidade de Brasília. Estudo sob supervisão do professor Mauro Luiz Rabelo, cujo objetivo é: Analisar os itens e as respostas dos estudantes do $8^{\circ}$ e $9^{\circ}$ ano do ensino fundamental às provas da OBMEP como meio para oferecer subsídios para a prática docente de professores de matemática.

Questões retiradas da prova da primeira fase da OBMEP de $2014 \mathrm{com}$ intuito verificar as resoluções dos participantes. 

APÊNDICE D - Questionário de Entrevista 


\section{Questionamentos para Estudo da Primeira Fase da OBMEP}

Prezado(a) participante:

Somos estudantes do curso de pós-graduação do programa PROFMAT - Mestrado Profissional em Matemática, do Departamento de Matemática da Universidade de Brasília. Estamos realizando dois estudos sob supervisão do professor Mauro Luiz Rabelo. O material de estudo é o mesmo - as avaliações da primeira fase da OBMEP de escolas do Distrito Federal - mas com enfoques diferentes.

O objetivo do primeiro estudo é : analisar os itens e as respostas dos estudantes do $8^{\circ}$ e $9^{\circ}$ ano do Ensino Fundamental às provas da primeira fase da OBMEP como meio para oferecer um feedback ao aluno e promover a valorização dessa avaliação

O objetivo do segundo estudo é : analisar os itens e as respostas dos estudantes do $8^{\circ}$ e $9^{\circ}$ ano do ensino fundamental às provas da OBMEP como meio para oferecer subsídios para a prática docente de professores de matemática.

Mas para dar continuidade aos nossos estudos precisamos saber mais sobre a elaboração dos itens da prova de primeira fase e sobre os resultados obtidos na RAIG das escolas que enviaram este documento para o IMPA.

Temos alguns questionamentos:

1- Se há uma matriz de referência para elaboração das questões?

2- Se é possível termos acesso a essa matriz de referência?

3- Como são utilizados os itens de ligação que estão presentes nos três níveis da OBMEP?

4- Como são caracterizados os itens pelo nível de dificuldade? E qual a sua distribuição na avaliação?

5- Se já foram computados os dados da RAIG? Se é possível disponibilizá-los?

6- Como são construídos os distratores de cada item?

7- Se há incentivo de uso de itens inéditos?

8- Se há normas de construção dos itens?

9- Se os itens são apenas desafiadores ou há pré-estabelecimento de avaliação de competências ou habilidades em cada item?

$\mathrm{Na}$ publicação dos resultados desta pesquisa, sua identidade será mantida no mais rigoroso sigilo. Serão omitidas todas as informações que permitam identificá-lo, identificar a escola e/ou identificar os estudantes em estudo. 
Mesmo não tendo benefícios diretos em participar, indiretamente você estará contribuindo para a compreensão do fenômeno estudado e para a produção de conhecimento científico.

Desde já agradecemos pela contribuição.

Quaisquer dúvidas relativas à pesquisa poderão ser esclarecidas pelas pesquisadoras:

Ana Paula Lima Vilarinho, e-mail: anaplvilarinho@gmail.com ou Regiane Quezia Gomes da Costa, e-mail regianegomez@gmail.com. autoras dos respectivos estudos. 

Anexos 

ANEXO A - RAIG 


\section{RELATÓRIO DE ACERTOS E INFORMAÇÕES GERAIS - RAIG}

Prezado(a) Diretor(a) e/ou Professor(a) Responsável,

Solicitamos a sua preciosa colaboração preenchendo os dados a seguir. Esse relatório não tem por objetivo avaliar as escolas, e dele não consta qualquer informação que permita identificá-las. Mais uma vez agradecemos a sua colaboração!

I. Do total de alunos de sua Escola que fizeram as provas da 1a Fase da OBMEP, quantos são, em cada nível, do sexo masculino e do sexo feminino?
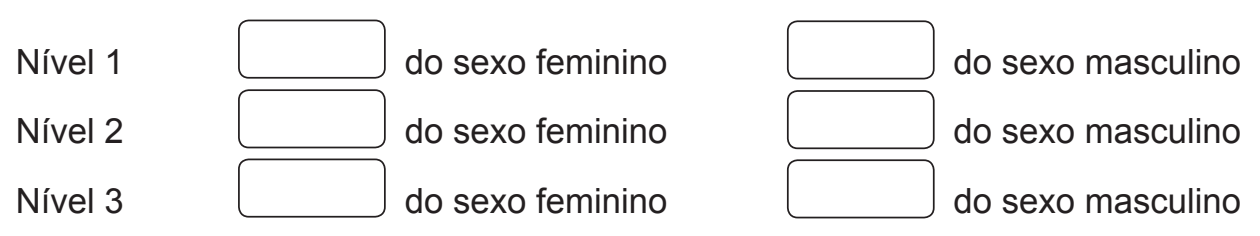

II. Preencha nos quadros abaixo o total de alunos que obtiveram a nota indicada, em cada nível.

Nível 1

\begin{tabular}{|c|c|c|c|c|c|c|c|c|c|c|c|c|c|c|c|c|c|c|c|c|c|c|}
\hline Nota & 0 & 1 & 2 & 3 & 4 & 5 & 6 & 7 & 8 & 9 & 10 & 11 & 12 & 13 & 14 & 15 & 16 & 17 & 18 & 19 & 20 & $\begin{array}{c}\text { Total de alunos } \\
\text { observados }\end{array}$ \\
\hline $\begin{array}{c}\text { Número de alunos que } \\
\text { obtiveram a nota indicada }\end{array}$ & & & & & & & & & & & & & & & & & & & & & \\
\hline
\end{tabular}

\section{Nível 2}

\begin{tabular}{|c|c|c|c|c|c|c|c|c|c|c|c|c|c|c|c|c|c|c|c|c|c|c|}
\hline Nota & 0 & 1 & 2 & 3 & 4 & 5 & 6 & 7 & 8 & 9 & 10 & 11 & 12 & 13 & 14 & 15 & 16 & 17 & 18 & 19 & 20 & $\begin{array}{c}\text { Total de alunos } \\
\text { observados }\end{array}$ \\
\hline $\begin{array}{c}\text { Número de alunos que } \\
\text { obtiveram a nota indicada }\end{array}$ & & & & & & & & & & & & & & & & & & & & & \\
\hline
\end{tabular}

\section{Nível 3}

\begin{tabular}{|c|c|c|c|c|c|c|c|c|c|c|c|c|c|c|c|c|c|c|c|c|c|c|}
\hline Nota & 0 & 1 & 2 & 3 & 4 & 5 & 6 & 7 & 8 & 9 & 10 & 11 & 12 & 13 & 14 & 15 & 16 & 17 & 18 & 19 & 20 & $\begin{array}{c}\text { Total de alunos } \\
\text { observados }\end{array}$ \\
\hline $\begin{array}{c}\text { Número de alunos que } \\
\text { obtiveram a nota indicada }\end{array}$ & & & & & & & & & & & & & & & & & & & & & \\
\hline
\end{tabular}


III. Informações Gerais:

1) A sua escola desenvolve atividades extracurriculares de Matemática?

$\square$ Sim Quais? $\square$ Clubes de Matemática

$\square$ Gincanas e competições internas

Grupos de estudo

Outras

Informe o material utilizado nas atividades

Não

2) Sobre o material preparado pela OBMEP:

a. Os professores de Matemática de sua escola conhecem o

Banco de Questões?

$\square \operatorname{Sim}$

Ele é trabalhado pelos professores em sala de aula?

$\square$ Não

b. Sobre o Banco de Questões, assinale quantas alternativas julgar conveniente:

$\square$ É difícil ou muito difícil para os alunos

$\square$ É adequado para a preparação dos alunos

$\square$ Deveria apresentar número maior de questões

$\square$ As soluções das questões propostas são bem explicadas

$\square$ As soluções das questões propostas deveriam ser mais detalhadas

$\square$ Deveria ser distribuído em maior quantidade em cada escola

$\square$ Muitos alunos o utilizam $\square$ Poucos alunos o utilizam

$\square$ Serve de inspiração aos professores para elaborar as provas da escola

c. Os professores de Matemática da sua escola trabalham em sala de aula as provas e as soluções da OBMEP?

$\square$ Sim, apenas da $1^{\text {a }}$ Fase $\square$ Sim, apenas da $2^{\text {a }}$ Fase
$\square$ Sim, das duas Fases

$\square$ Não Por quê?

d. Coloque aqui observações e comentários sobre as provas da $1^{\text {a }}$ Fase: e. Os professores de Matemática de sua escola conhecem os vídeos com as soluções das provas da Obmep?

$\square$ Sim

$\square$ Não

f. Os vídeos com as soluções das provas da Obmep são utilizados

- em sala de aula com alunos?

- para discussão entre professores?

- para planejamento de aulas e/ou atividades?

$\square \operatorname{Sim} \square$ Não

$\square \operatorname{Sim} \square$ Não

$\square \operatorname{Sim} \square$ Não

3) Com que frequência você e os professores de Matemática de sua escola acessam o site da OBMEP (www.obmep.org.br)?

$\square$ Nunca

$\square$ Raramente

$\square$ Frequentemente

4) O que você e os professores de sua escola procuram no site da OBMEP? (escolha até 2 opções)

$\square$ Notícias gerais sobre eventos

$\square$ Material didático

$\square$ Informações sobre as fases da OBMEP

Regulamento e outras instruções

Outros

5) Sobre o Programa de Iniciação Científica (PIC) para os medalhistas da OBMEP:

a. Os professores de sua escola conhecem o PIC?
$\square \operatorname{Sim}$
$\square$ Não
$\square$ Não, mas gostariam de conhecer

b. E o material (apostilas, etc.) do PIC?

$\square$ Conhecem

$\square$ Não conhecem

$\square$ Não, mas gostariam de receber

6) A OBMEP vem sendo realizada há dez anos. No decorrer desse tempo, você e seus colegas professores notaram em sua escola:

a. que os alunos em geral se interessam mais pela OBMEP, seus prêmios e programas?

$\square$ Sim

$\square$ Não

b. que aqueles alunos que participam da OBMEP apresentam progressos em Matemática?

$\square$ Sim

$\square$ Não 

ANEXO B - Prova OBMEP 2014 


\section{WT77 $10^{a}$ OLIMPIADA BRASILEIRA DE MATEMÁTICA DAS ESCOLAS PÚBLICAS | OBMEP 2014}

Nome completo do(a) aluno(a):

\section{INSTRUÇÕES}

1. Preencha o cartão-resposta com seu nome completo, sexo, telefone, endereço eletrônico, data de nascimento, ano e turno em que estuda, e lembre-se de assiná-lo.

2. A duração da prova é de 2 horas e 30 minutos.

3. Cada questão tem cinco alternativas de resposta: $(A),(B),(C),(D)$ e $(E)$ e apenas uma delas é correta.

4. Para cada questão marque a alternativa escolhida no cartão-resposta, preenchendo todo o espaço dentro do círculo correspondente a lápis ou a caneta esferográfica azul ou preta (é preferível a caneta).

\section{(A) (C) (D) (E)}

5. Marque apenas uma alternativa para cada questão. Atenção: se você marcar mais de uma alternativa, perderá os pontos da questão, mesmo que uma das alternativas marcadas seja correta.

6. Não é permitido o uso de instrumentos de desenho, calculadoras ou quaisquer fontes de consulta.

7. Os espaços em branco na prova podem ser usados para rascunho.

8. Ao final da prova, entregue-a ao professor junto com o cartão-resposta.

Visite nossas
páginas na Internet:

1. Paula numerou todas as casas do tabuleiro quadrado abaixo, da esquerda para a direita e de cima para baixo, começando com o número 1 . A casa central recebeu o número 5 . Se ela fizer o mesmo com outro tabuleiro quadrado com 49 casas, qual número será escrito em sua casa central?
A) 23
B) 25
C) 27
D) 29
E) 31

\begin{tabular}{|l|l|l|}
\hline 1 & 2 & 3 \\
\hline 4 & 5 & 6 \\
\hline 7 & 8 & 9 \\
\hline
\end{tabular}

2. Ana Maria apertou as teclas $1,9, x, 0,6]$ de sua calculadora e o resultado 2014 apareceu no visor. Em seguida, ela limpou o visor e fez aparecer novamente 2014 com uma multiplicação de dois números naturais, mas, desta vez, apertando seis teclas em vez de sete. Nesta segunda multiplicação, qual foi o maior algarismo cuja tecla ela apertou?
A) 5
B) 6
C) 7
D) 8
E) 9

3. Na figura, os pontos $A, B$ e $C$ estão alinhados. Qual é a soma dos ângulos marcados em cinza?
A) $120^{\circ}$
B) $180^{\circ}$
C) $270^{\circ}$
D) $360^{\circ}$
E) $540^{\circ}$

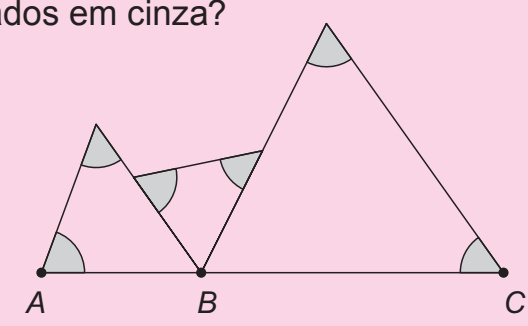

4. A sequência $-6,12,-18,24,-30,36, \ldots$ é obtida a partir dos múltiplos positivos de 6 , multiplicando-se os termos nas posições ímpares por -1 . Observe na figura que a soma dos dois primeiros termos da sequência é igual a 6 e a soma dos três primeiros termos é igual a -12 . Quantos termos consecutivos dessa sequência devemos somar, a partir do primeiro, para obter 180 como resultado?
A) 30
B) 60
C) 90
D) 120
E) 180 
5. Os irmãos Luiz e Lúcio compraram um terreno cercado por um muro de 340 metros. Eles construíram um muro interno para dividir o terreno em duas partes. A parte de Luiz ficou cercada por um muro de 260 metros e a de Lúcio, por um muro de 240 metros. Qual é o comprimento do muro interno?
A) $80 \mathrm{~m}$
B) $100 \mathrm{~m}$
C) $160 \mathrm{~m}$
D) $180 \mathrm{~m}$
E) $200 \mathrm{~m}$

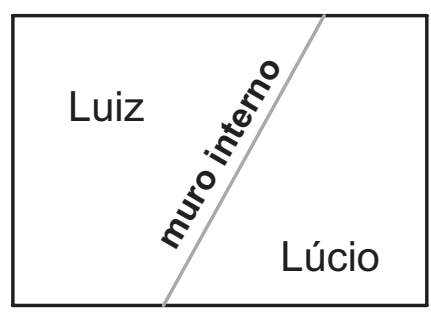

6. Cinco meninas não estão totalmente de acordo sobre a data da prova de Matemática.

- Andrea diz que será em agosto, dia 16, segundafeira;

- Daniela diz que será em agosto, dia 16, terça-feira;

- Fernanda diz que será em setembro, dia 17, terçafeira;

- Patrícia diz que será em agosto, dia 17, segundafeira;

- Tatiane diz que será em setembro, dia 17, segundafeira.

Somente uma está certa, e as outras acertaram pelo menos uma das informações: o mês, o dia do mês ou o dia da semana. Quem está certa?
A) Andrea
B) Daniela
C) Fernanda
D) Patrícia
E) Tatiane

7. Rodrigo comprou três cadernos iguais em uma promoção na qual o segundo e o terceiro cadernos eram vendidos, respectivamente, com $20 \%$ e $40 \%$ de desconto sobre o preço do primeiro. No dia seguinte, terminada a promoção, Gustavo comprou três cadernos iguais aos de Rodrigo, todos sem desconto. Percentualmente, quanto Rodrigo pagou a menos que Gustavo?
A) $20 \%$
B) $22 \%$
C) $25 \%$
D) $28 \%$
E) $30 \%$

8. O professor Michel aplicou duas provas a seus dez alunos e divulgou as notas por meio do gráfico mostrado abaixo. Por exemplo, o aluno A obteve notas 9 e 8 nas provas 1 e 2, respectivamente; já o aluno $B$ obteve notas 3 e 5 . Para um aluno ser aprovado, a média aritmética de suas notas deve ser igual a 6 ou maior do que 6. Quantos alunos foram aprovados?
A) 6
B) 7
C) 8
D) 9
E) 10

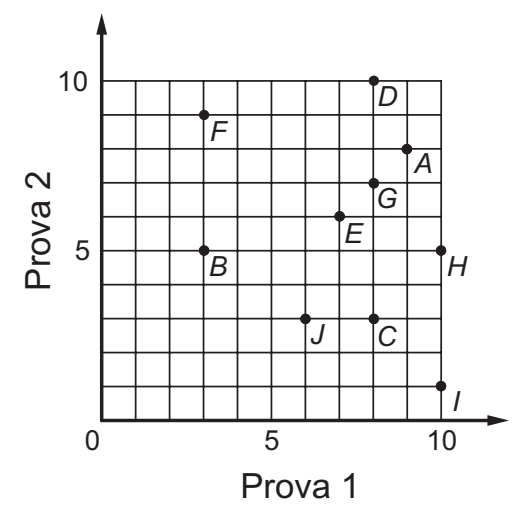

9. $O$ polígono $A B C D E F$ é um hexágono regular. Os pontos $M$ e $N$ são pontos médios dos lados $A F$ e $B C$, respectivamente. O hexágono $A B N G H M$ é simétrico em relação à reta que passa por $M$ e $N$. Qual é a razão entre as áreas dos hexágonos $A B N G H M$ e $A B C D E F ?$
A) $\frac{3}{10}$
B) $\frac{4}{11}$
C) $\frac{3}{7}$
D) $\frac{7}{15}$
E) $\frac{5}{12}$

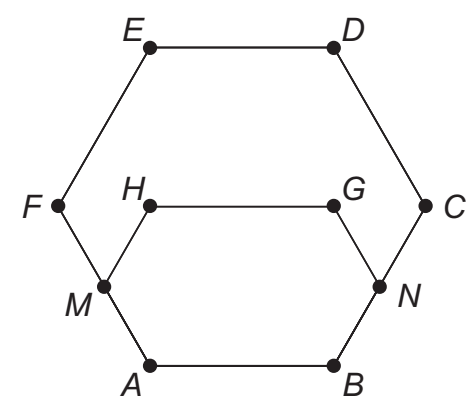

10. Sempre que Yurika abastece seu carro, ela enche o tanque e anota a data, a quilometragem marcada no painel e a quantidade de litros de combustível colocada. $\mathrm{Na}$ tabela estão os dados registrados por Yurika em dois abastecimentos consecutivos. Quantos quilômetros por litro, aproximadamente, fez o carro de Yurika nesse período?
A) 5,6
B) 9,8
C) 11,1
D) 12,9
E) 40,1

\begin{tabular}{|c|c|c|}
\hline data & $\mathrm{km}$ & litros \\
\hline$\vdots$ & $\vdots$ & $\vdots$ \\
\hline $01 / 02$ & 35723 & 32,5 \\
\hline $07 / 02$ & 36144 & 43,0 \\
\hline$\vdots$ & $\vdots$ & $\vdots$ \\
\hline
\end{tabular}


11. Todos os números de 1 a 24 devem ser escritos nas faces de um cubo, obedecendo-se às seguintes regras:

- em cada face devem ser escritos quatro números consecutivos;

- em cada par de faces opostas, a soma do maior número de uma com o menor número da outra deve ser igual a 25 .

Se os números 7 e 23 estiverem escritos no cubo como na figura, qual é o menor número que pode ser escrito na face destacada em cinza?
A) 1
B) 5
C) 9
D) 11
E) 17

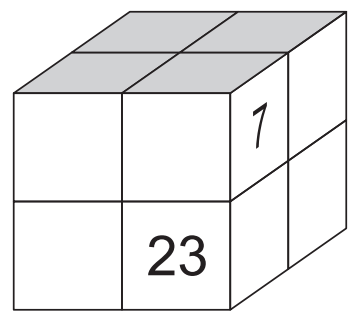

12. Começando com um quadrado de $1 \mathrm{~cm}$ de lado, formamos uma sequência de figuras, como na ilustração. Cada figura, a partir da segunda, é formada unindo-se três cópias da anterior. Os contornos destacados em vermelho das quatro primeiras figuras medem, respectivamente, $4 \mathrm{~cm}, 8 \mathrm{~cm}, 20 \mathrm{~cm}$ e $56 \mathrm{~cm}$. Quanto mede o contorno da Figura 6?
A) $88 \mathrm{~cm}$
B) $164 \mathrm{~cm}$
C) $172 \mathrm{~cm}$
D) $488 \mathrm{~cm}$
E) $492 \mathrm{~cm}$

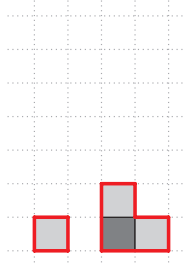

Figura 1 Figura 2

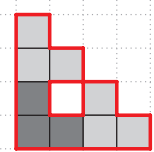

Figura 3

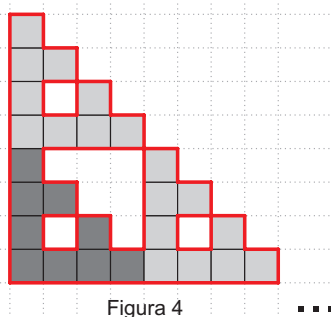

13. $\mathrm{Na}$ conta indicada a seguir, as letras $\mathrm{X}, \mathrm{Y}$ e $\mathrm{Z}$ representam algarismos distintos. Qual é o algarismo representado pela letra $Z$ ?
A) 1
B) 3
C) 5
D) 6
E) 8

14. Rosane percebeu que seu antigo relógio de parede tinha parado às 9 horas. Ela deu corda no relógio, colocando-o para funcionar sem acertar o horário, e foi imediatamente ao mercado. Chegou ao mercado às 10 horas e 10 minutos. Fez suas compras em 1 hora e voltou para casa. Entrando em casa, notou que o relógio de parede marcava 10 horas e 40 minutos. Se Rosane realizou os percursos de ida e volta ao mercado em tempos iguais, a que horas ela entrou em casa?

A) 10 horas e 50 minutos

B) 11 horas e 10 minutos

C) 11 horas e 30 minutos

D) 11 horas e 40 minutos

E) 11 horas e 50 minutos

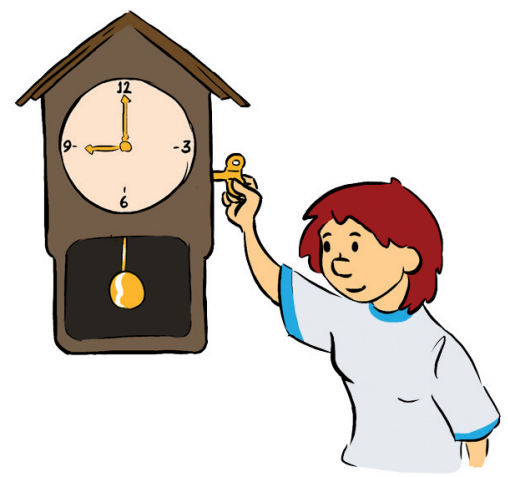

15. Télio comprou laranjas, maçãs e uvas no mercado. O preço por quilograma de cada fruta está na tabela abaixo. Metade do peso total da compra era de maçãs e o peso das uvas era o dobro do peso das laranjas. Se Télio gastou $\mathrm{R} \$ 38,00$, quantos quilogramas de frutas ele comprou?
A) 10
B) 11
C) 12
D) 13
E) 14

\begin{tabular}{|c|c|}
\hline \multicolumn{2}{|c|}{$\begin{array}{c}\text { Preços (R\$) por } \\
\text { quilograma }\end{array}$} \\
\hline Maçã & 3,00 \\
\hline Uva & 4,00 \\
\hline Laranja & 2,00 \\
\hline
\end{tabular}

16. A mãe de Lúcia pediu para ela não comer mais de 10 docinhos por dia. Além disso, se em um dia ela comer mais de 7 docinhos, nos dois dias seguintes não poderá comer mais de 5 docinhos em cada dia. Qual é o maior número de docinhos que Lúcia pode comer durante um período de 29 dias seguidos, obedecendo ao pedido de sua mãe?
A) 203
B) 204
C) 206
D) 213
E) 290 
17. Gustavo possui certa quantidade de moedas de 1,10 , 25 e 50 centavos, tendo pelo menos uma de cada valor. É impossível combiná-las de modo a obter exatamente 1 real. Qual é o maior valor total possível para suas moedas?
A) 86 centavos
B) 1 real e 14 centavos
C) 1 real e 19 centavos
D) 1 real e 24 centavos
E) 1 real e 79 centavos

19. Um cubo de madeira foi pintado de vermelho e depois cortado em $n^{3}$ cubinhos iguais, $n>2$. Alguns desses cubinhos ficaram sem nenhuma face pintada e outros com uma, duas ou três faces pintadas. Se o número de cubinhos sem nenhuma face pintada é igual ao número de cubinhos com exatamente uma face pintada, qual é o valor de $n$ ?
A) 7
B) 8
C) 9
D) 10
E) 11

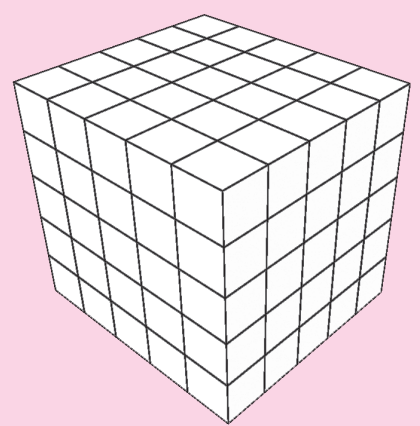

20. Rodrigo brinca com uma fita de dois metros, com marcas de centímetro em centímetro. Começando pela ponta de marca $0 \mathrm{~cm}$, ele dobra a fita várias vezes em zigue-zague, como na figura, sobrepondo pedaços de fita de mesmo tamanho até dobrar um último pedaço, que pode ser menor do que os demais. Ele observa que as marcas de $49 \mathrm{~cm}$ e de $71 \mathrm{~cm}$ ficaram sobrepostas em pedaços vizinhos. Ele observa também que a marca de $139 \mathrm{~cm}$ ficou alinhada com elas. Com qual marca do penúltimo pedaço a ponta final da fita ficou sobreposta?
A) $160 \mathrm{~cm}$
B) $176 \mathrm{~cm}$
C) $184 \mathrm{~cm}$
D) $190 \mathrm{~cm}$
E) $196 \mathrm{~cm}$

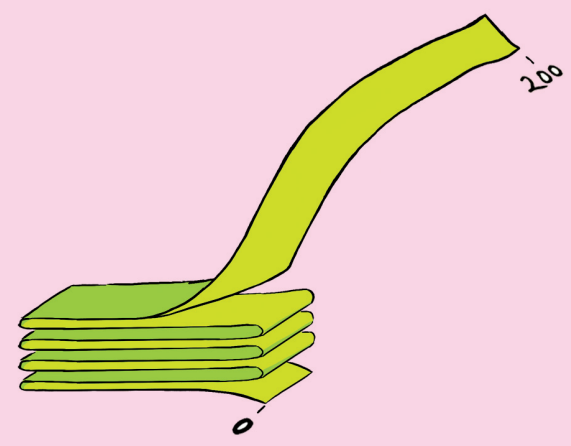



ANEXO C - Solução da Prova da OBMEP 2014 


\section{QUESTÃO 1 \\ ALTERNATIVA B}

O tabuleiro $7 \times 7$ pode ser facilmente preenchido e constata-se que na casa central deve aparecer o número 25, mas existe uma maneira melhor de fazer isto: no tabuleiro quadrado de 49 casas, a quantidade de números antes da casa central é igual à quantidade de números distribuídos depois da casa central. Logo, chamando de $x$ o número que ocupa a casa central temos $x-1$ números antes dele e $49-x$ depois dele. Portanto, $x-1=49-x$, donde $2 x=50$. Portanto, $x=25$. De modo geral, para qualquer tabuleiro quadrado de $2 n+1$ casas (um número ímpar), o número $x$ que aparece na casa central satisfaz a igualdade $x-1=(2 n+1)-x$. Logo, $2 x=2 n+2$ e, portanto, $x=n+1$.

\section{QUESTÃO 2}

\section{ALTERNATIVA D}

Observe que $2014=19 \times 106=2 \times 19 \times 53$. Assim, a menos da ordem dos fatores, existem somente quatro formas possíveis de se fazer aparecer 2014 na calculadora como uma multiplicação de dois números naturais:

- Apertando sete teclas: $1 \times 2014=$

- Apertando sete teclas: $2 \times 1007=$

- Apertando sete teclas: $19 \times 106=$

- Apertando seis teclas: $38 \times 53=$

(Este fato se deve à decomposição única de um número inteiro positivo em fatores primos, a menos da ordem dos fatores. Os fatores primos de 2014 são 2, 19 e 53).

Dentre as quatro possibilidades, em só uma delas seis teclas são pressionadas; concluímos então que as seis teclas que Ana Maria apertou foram 3, 8, x, 5, $3 \mathrm{e}=$. Portanto, o maior algarismo cuja tecla ela apertou foi 8.

\section{QUESTÃO 3}

\section{ALTERNATIVA D}

A soma dos ângulos internos de um triângulo é $180^{\circ}$. Observe que os três ângulos não marcados dos triângulos (com vértices em $B$ ) somam $180^{\circ}$, já que $A, B$ e $C$ estão alinhados. Assim, a soma dos ângulos marcados é $\left(180^{\circ} \times 3\right)-180^{\circ}=360^{\circ}$.

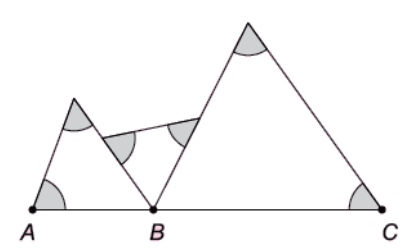

\section{QUESTÃO 4}

\section{ALTERNATIVA B}

Podemos organizar as somas dos termos da sequência aos pares:

$$
(-6+12)+(-18+24)+(-30+36)+(-42+48)+\cdots
$$

Observamos que, para cada par de termos consecutivos, arranjados como acima, a soma é 6 . Assim, para obter 180 devemos somar os $180 \div 6=30$ primeiros pares, ou seja, os $30 \times 2=60$ primeiros termos da sequência.

\section{QUESTÃO 5}

\section{ALTERNATIVA A}

Somando as metragens dos muros de Luiz e de Lúcio, obtemos $240+260=500 \mathrm{~m}$. Neste total estão computados o comprimento do muro original (de $340 \mathrm{~m}$ ) mais duas vezes o comprimento do muro interno. Logo, o comprimento do muro interno é igual a $[500-340] / 2=80$ metros.

Podemos também resolver algebricamente: como o muro interno pertence ao cercado dos terrenos de Luiz e de Lúcio, se $x$ é a medida do muro interno, temos:

$$
\begin{gathered}
340+2 x=240+260 \\
\text { Portanto } x=80 \mathrm{~m} .
\end{gathered}
$$




\section{QUESTÃO 6}

\section{ALTERNATIVA D}

Podemos organizar as informações numa tabela:

\begin{tabular}{|l|l|c|c|}
\hline & \multicolumn{1}{|c|}{ mês } & dia do mês & dia da semana \\
\hline Andrea & agosto & 16 & segunda \\
\hline Daniela & agosto & 16 & terça \\
\hline Fernanda & setembro & 17 & terça \\
\hline Patrícia & agosto & 17 & segunda \\
\hline Tatiane & setembro & 17 & segunda \\
\hline
\end{tabular}

Se Andrea estivesse certa, então Fernanda não acertaria nenhuma das informações. Logo, não é ela que está certa, nem Fernanda (pelo mesmo motivo). Se Daniela estivesse certa, então Tatiane também nada acertaria. Logo Daniele e Tatiane não estão certas. Se Patrícia acertar tudo, as demais também acertarão alguma informação e, portanto, Patrícia é a única que está certa.

\section{QUESTÃO 7}

\section{ALTERNATIVA A}

Se P é o preço de um caderno, Rodrigo pagou pela sua compra

$$
P+\frac{80}{100} P+\frac{60}{100} P=P+0,8 P+0,6 P=2,4 P,
$$

enquanto que Gustavo, no dia seguinte, pagou 3P. Portanto, Rodrigo pagou

$$
3 \cdot P-2,4 P=0,6 P
$$

a menos que Gustavo. Assim, para saber percentualmente quanto Rodrigo pagou a menos do que Gustavo, fazemos

$$
\begin{aligned}
3 P & -100 \% \\
0,6 P & =x
\end{aligned}
$$

Logo, $x=\frac{0,6 P}{3 P}=0,2=\frac{20}{100}$, ou seja, Rodrigo pagou $20 \%$ a menos que Gustavo.

\section{QUESTÃO 8}

\section{ALTERNATIVA A}

De acordo com o gráfico, os alunos obtiveram as seguintes notas e médias:

\begin{tabular}{|c|c|c|c|}
\hline & Prova 1 & Prova 2 & Média Aritmética \\
\hline$A$ & 9 & 8 & 8,5 \\
\hline$B$ & 3 & 5 & 4 \\
\hline$C$ & 8 & 3 & 5,5 \\
\hline$D$ & 8 & 10 & 9 \\
\hline$E$ & 7 & 6 & 6,5 \\
\hline$F$ & 3 & 9 & 6 \\
\hline$G$ & 8 & 7 & 7,5 \\
\hline$H$ & 10 & 5 & 7,5 \\
\hline$I$ & 10 & 1 & 5,5 \\
\hline$J$ & 6 & 3 & 4,5 \\
\hline
\end{tabular}

Assim, somente os alunos $A, D, E, F, G$ e $H$ ficaram com média aritmética maior do que ou igual a 6 e, dos dez alunos, somente seis foram aprovados. 


\section{QUESTÃO 9}

\section{ALTERNATIVA E}

As diagonais que ligam vértices opostos dividem o hexágono regular em seis triângulos equiláteros congruentes, com lado igual ao do hexágono. Por outro lado, os segmentos $M H$ e GN determinam triângulos equiláteros $F H M$ e $C G N$ com lado igual à metade do lado do hexágono. Logo, a área de cada um destes dois triângulos é igual a $\frac{S}{4}$, sendo $S$ a área dos triângulos equiláteros maiores. Assim, a razão entre as áreas dos hexágonos $A B N G H M$ e $A B C D E F$ é

$$
\frac{3 S-2 \frac{S}{4}}{6 S}=\frac{5}{12}
$$

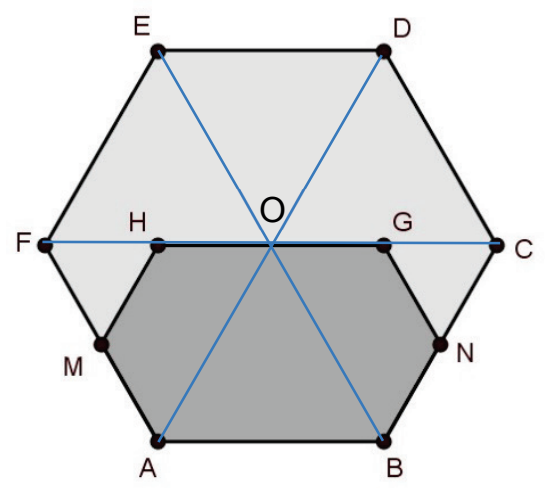

Uma outra solução consiste em decompor o hexágono regular em 24 pequenos triângulos equiláteros congruentes e verificar que o hexágono cinza é formado por 10 de tais triângulos pequenos. Assim, a razão entre as áreas é $\frac{10}{24}=\frac{5}{12}$.

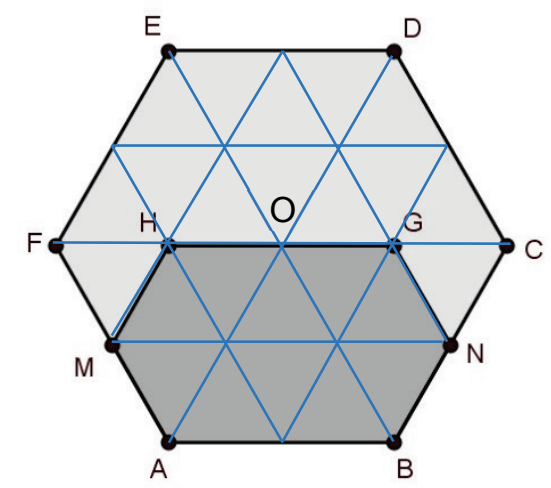

\section{QUESTÃO 10}

\section{ALTERNATIVA B}

Yurika andou $36144-35723=421 \mathrm{~km}$. Ela gastou 43 litros para andar esta quilometragem; portanto, o rendimento de seu carro foi de $421 \div 43 \mathrm{~km} / \mathrm{l}$, ou seja, aproximadamente $9,8 \mathrm{~km} / \mathrm{l}$. O dado 32,5 é irrelevante para resolver o problema, já que ela sempre enche o tanque quando abastece.

\section{QUESTÃO 11}

\section{ALTERNATIVA C}

Como em cada face aparecem quatro números consecutivos, então na face onde estiver o número 1, obrigatoriamente estarão os números 1, 2, 3 e 4 . Logo, na face onde estiver o número 5 estarão os números $5,6,7$ e 8 , e assim, sucessivamente, até chegarmos à face com os números 21, 22, 23 e 24.

Sendo assim, no cubo apresentado a face com o número 23 também apresenta os números 21, 22 e 24. Como o enunciado diz que a soma do maior número de uma face com o menor da face oposta é igual a 25, podemos concluir que na face oposta à que contém o 23 estão os números $1,2,3$ e 4 . Na face em que aparece o

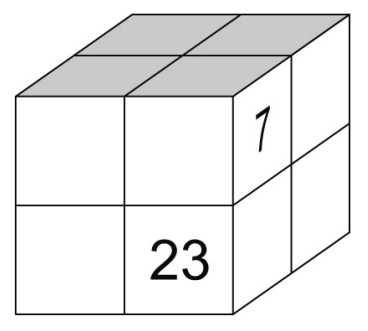
número 7 aparecem os números 5,6 e 8 , e na face oposta a esta estão os números $17,18,19$ e 20. Logo, na face destacada (em cinza) pode estar qualquer número de 9 até 16.

Como a pergunta é qual é o menor número que pode aparecer na face cinza, a resposta é 9. 


\section{QUESTÃO 12}

\section{ALTERNATIVA D}

Cada figura é formada por 3 cópias da figura anterior, posicionadas de modo a colocar em contato apenas dois pares de quadradinhos das cópias das figuras. Em consequência, o comprimento do contorno da nova figura é igual a 3 vezes o comprimento do contorno da anterior, menos $4 \mathrm{~cm}$ (correspondentes aos lados em contato).

A tabela abaixo dá o comprimento do contorno das sucessivas figuras.

\begin{tabular}{|l|l|}
\hline Figura & Contorno (cm) \\
\hline 1 & 4 \\
\hline 2 & $3 \times 4-4=8$ \\
\hline 3 & $3 \times 8-4=20$ \\
\hline 4 & $3 \times 20-4=56$ \\
\hline 5 & $3 \times 56-4=164$ \\
\hline 6 & $3 \times 164-4=488$ \\
\hline
\end{tabular}

Portanto, o contorno da Figura 6 mede $488 \mathrm{~cm}$.

\section{QUESTÃO 13}

\section{ALTERNATIVA E}

Observe a soma das unidades. Como $0<X+Y \leq 18$, temos que $X+Y=10$, pois $X+Y+Z$ e $Z$ devem ter o mesmo algarismo na casa das unidades. Segue também que somando-se os números na casa das unidades, "vai um" para a casa das dezenas. A partir da soma das dezenas temos que $1+X+Y+Z=11+Z$ e $X$ devem ter o mesmo algarismo na casa das unidades, isto só é possível se $X=Z+1$. Observando a casa do milhar, vemos que a soma $1+X+Y+Z=11+Z$ deve ser igual ao número com dezena $Y$ e unidade $X$. Logo, $Y=1$ e como $X+Y=10, X=9$. Mas $X=Z+1$, o que fornece $Z=8$. Assim, a conta apresentada é, de fato,

\section{9 \\ 1111 \\ $+8888$

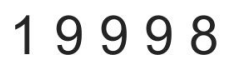

Uma outra solução é a seguinte:

Olhando a casa das unidades, concluímos, como antes, que $X+Y=10$, pois $X+Y+Z$ e $Z$ devem ter o mesmo algarismo na casa das unidades. Devido à posição da letra $Y$ no resultado, podemos concluir que $Y=2$ ou $Y=1$, pois $X, Y$ e $Z$ sendo algarismos, são, no máximo, iguais a 9. Vejamos o que ocorre em cada caso:

Se $Y=2$, então $X=8$ e, olhando a casa dos milhares, vemos que $1+8+2+Z=28$, donde $Z=17$, o que é impossível, pois $Z$ é um algarismo $(Z<10)$.

Se $Y=1$, como $X+Y=10$, então $X=9$ e, olhando novamente a casa dos milhares, vemos que $1+9+1+Z=19$, donde $Z=8$.

\section{QUESTÃO 14}

\section{ALTERNATIVA C}

Supondo que o relógio de parede começou a funcionar normalmente quando marcava $9 \mathrm{~h}$, ao mostrar $10 \mathrm{~h}$ $40 \mathrm{~min}$ o tempo que passou foi de $1 \mathrm{~h}$ e $40 \mathrm{~min}$. Como Rosane ficou exatamente uma hora fazendo compras, conclui-se que ela levou 40 min para ir e voltar e, como esses tempos são iguais, levou 20 min para voltar. Admitindo-se que o relógio do mercado que marcava 10h 10min estava correto, então ela chegou em casa $1 \mathrm{~h}$ e $20 \mathrm{~min}$ depois das $10 \mathrm{~h}$ e $10 \mathrm{~min}$, ou seja, ela chegou em casa às 11 horas e 30 minutos. 


\section{QUESTÃO 15 \\ ALTERNATIVA C}

Chamando de $T$ o peso total das frutas, $m$ o peso (massa) das maçãs, $u$ o peso das uvas e $I$ o peso das laranjas, os dados do problema nos fornecem

$$
m=T / 2, u+l=T / 2 \text { e } u=2 I
$$

donde concluímos que $m=T / 2, u=T / 3$ e $I=T / 6$. Portanto, de acordo com a tabela de preços, teremos:

$$
3 \cdot \frac{\mathrm{T}}{2}+4 \cdot \frac{\mathrm{T}}{3}+2 \cdot \frac{\mathrm{T}}{6}=38 \therefore \mathrm{T}=12
$$

Logo, Télio comprou $12 \mathrm{~kg}$ de frutas.

\section{QUESTÃO 16 \\ ALTERNATIVA C}

A cada grupo de 3 dias Lúcia pode comer $\left\{\begin{array}{c}7+7+7=21 \text { docinhos } \\ \text { ou } \\ 10+5+5=20 \text { docinhos }\end{array}\right.$.

Portanto, para maximizar a quantidade de docinhos ela deverá sempre fazer a primeira escolha a cada grupo de 3 dias. Como $29=9 \times 3+2$, já podemos concluir que nos 9 períodos de 3 dias ela comerá 9x21 = 189 docinhos.

Resta analisar de que maneiras ela pode tentar maximizar a quantidade de docinhos nos dois últimos dias.

Opções: $\left\{\begin{array}{l}7+7=14 \text { docinhos } \\ 10+5=15 \text { docinhos } \\ 7+10=17 \text { docinhos }\end{array}\right.$

A terceira possibilidade é a maior de todas. Logo, a maior quantidade de docinhos que ela pode comer é $189+17=206$.

\section{QUESTÃO 17 \\ ALTERNATIVA C}

Como José possui pelo menos uma moeda de cada tipo, ele não pode ter 2 moedas de 50 centavos, senão formaria 1 real. Ele também não pode ter 2 moedas de 25 centavos. Com a moeda de 50 centavos e com uma moeda de 25 centavos ele também não pode formar 1 real. Concluímos assim, que José possui uma moeda de 50 centavos e uma moeda de 25 centavos. José não pode ter 5 moedas de 10 centavos, senão junto com a moeda de 50 centavos ele formaria 1 real. Para maximizar, podemos supor que ele tem, então, quatro moedas de 10 centavos. Com elas e com as moedas de 50 e 25 centavos ele não consegue formar 1 real. Por fim, ele não pode ter cinco moedas de 1 centavo, pois se tivesse, formaria 1 real juntando a elas a moeda de 50 centavos com a de 25 centavos e mais duas de 10 centavos. Assim, José deve ter, no máximo, quatro moedas de 1 centavo. Logo, o maior valor total possível que José pode ter é $50+25+4 \cdot 10+4 \cdot 1=119$ centavos, ou seja, $R \$ 1,19$.

\section{QUESTÃO 18}

\section{ALTERNATIVA E}

Vamos fazer essa contagem pensando em colocar os algarismos na unidade, dezena, centena e unidade de milhar do número.

Como se trata de um número de quatro algarismos, o algarismo 0 não pode ser colocado na unidade de milhar. Temos então 3 possibilidades para se colocar o algarismo 0.

Colocado o zero sobram então três posições para se colocar o algarismo ímpar, e como há cinco algarismos ímpares, temos um total de 15 possibilidades para se colocar o algarismo ímpar no número.

Colocado o algarismo 0 e o algarismo ímpar, sobram duas posições para se colocar os dois algarismos pares não nulos e distintos. Fazemos a escolha do primeiro algarismo par não nulo e o colocamos na primeira posição ainda não preenchida do número (há apenas 4 possibilidades de escolha: 2, 4, 6 e 8). Finalmente, preenchemos a última posição com outro número par não nulo, diferente daquele anteriormente colocado ( 3 possibilidades). Temos assim 12 possibilidades de se colocar os dois algarismos pares não nulos e distintos no número.

Pelo Princípio Multiplicativo, o total de possibilidades é $3 \times 15 \times 12=540$. 


\section{QUESTÃO 19}

\section{ALTERNATIVA B}

Os cubinhos que não têm nenhuma face pintada são os que ficam internos ao cubo maior. Eles fazem parte de um cubo de dimensões $(n-2) \times(n-2) \times(n-2)$, o que dá um total de $(n-2)^{3}$ tais cubinhos. Os que têm exatamente uma face pintada são os cubinhos das faces do cubo maior que não tocam suas arestas. Em cada face há $(n-2)^{2}$ desses cubinhos, o que dá um total de $6(n-2)^{2}$ cubinhos com exatamente uma face pintada. Logo, deve-se ter

$$
(n-2)^{3}=6 \cdot(n-2)^{2}
$$

Como $n>2$, esta equação é equivalente a $n-2=6$, cuja solução é $n=8$.

\section{QUESTÃO 20}

\section{ALTERNATIVA D}

Como as marcas 49 e 71 ficaram sobrepostas em pedaços que são vizinhos, houve uma dobra exatamente no ponto médio, isto é, em $(49+71) / 2=60$. Como o processo iniciou-se com a marca 0 , o tamanho de cada pedaço, isto é, a distância entre duas dobras sucessivas, deve ser um divisor de 60 . Os divisores de 60 são $1,2,3,4,5,6,10,12,15,20,30$ e o próprio 60. Mas, estando 49 e 71 em pedaços vizinhos, descartamos os divisores 1, 2, 3, 4, 5, 6 e 10 pois a distância de 49 (ou 71) até a dobra 60 é 11, maior do que todos eles. Resta decidir qual é o tamanho de cada pedaço dentre as possibilidades $12,15,20,30$ ou 60 e, para isto, usaremos a informação de que a marca 139 ficou alinhada com 49 e 71.

As distâncias da marca de 139 aos dois pontos anteriores são, respectivamente, 90 e 68. Como a marcação de 139 coincide com as anteriores, uma dessas distâncias deve ser um múltiplo do dobro do tamanho da dobra, ou seja, deve ser um múltiplo de 24, 30, 40, 60 ou 120. Mas 68 não é um múltiplo de nenhum desses números, enquanto 90 é múltiplo apenas de 30 . Portanto, o tamanho de cada pedaço é 15 , o que faz com que a última dobra ocorra na marca de $195 \mathrm{~cm}$ e, daí, ao dobrar-se o último pedaço, a marca de 200 $\mathrm{cm}$ fica sobre $195-(200-195)=190 \mathrm{~cm}$.

As figuras a seguir ilustram o que acontece para os cinco possíveis valores das medidas dos pedaços.

Se o tamanho de cada pedaço fosse igual a 12, teríamos a situação descrita pela figura ao lado e a marca 139 não estaria alinhada com 71 e 49. Logo, este caso não ocorre.

Se o tamanho de cada pedaço fosse igual a 15 , teríamos a seguinte situação:
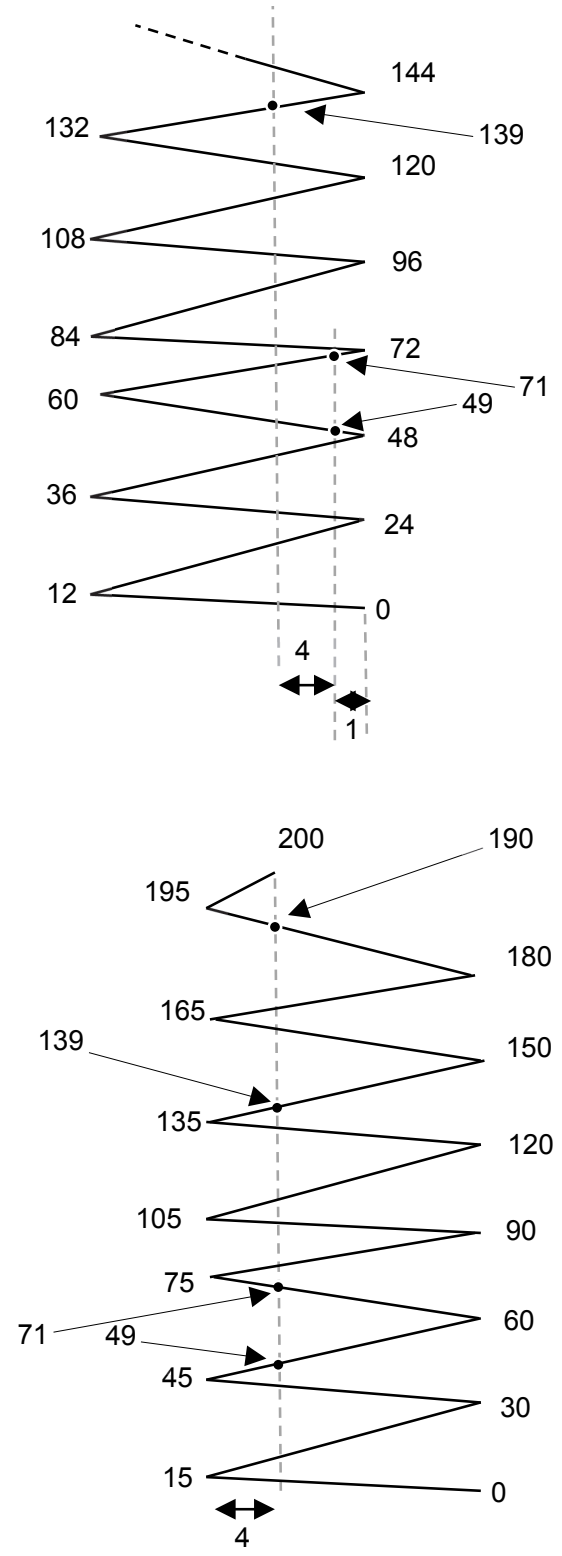
Este é o único caso correto. De fato, veremos a seguir que os demais casos não podem ocorrer:

Se o tamanho de cada pedaço fosse igual a 20 , teríamos a seguinte situação:

Este caso também não pode ocorrer pois 139 não se alinha com 49 e 71 .

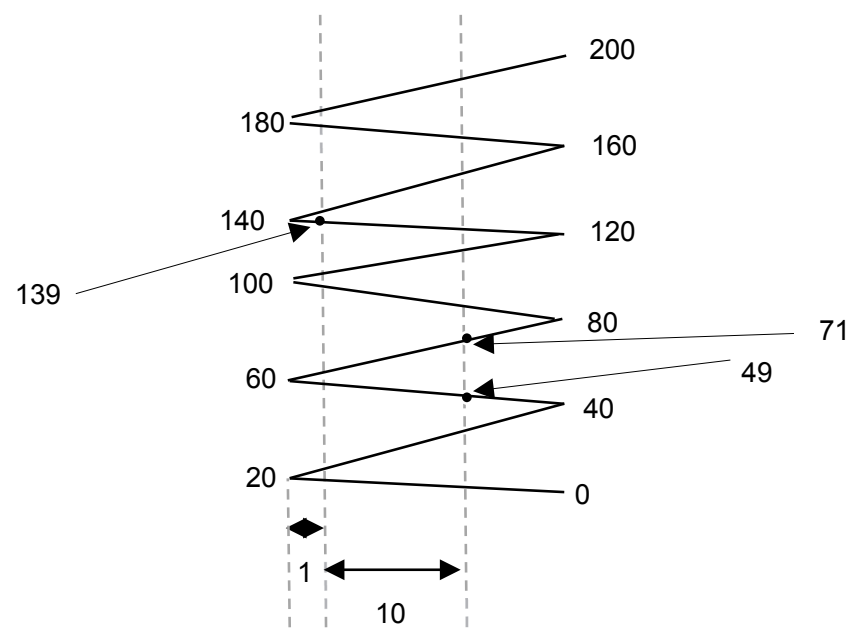

Se o tamanho de cada pedaço fosse igual a 30 , teríamos a seguinte situação:

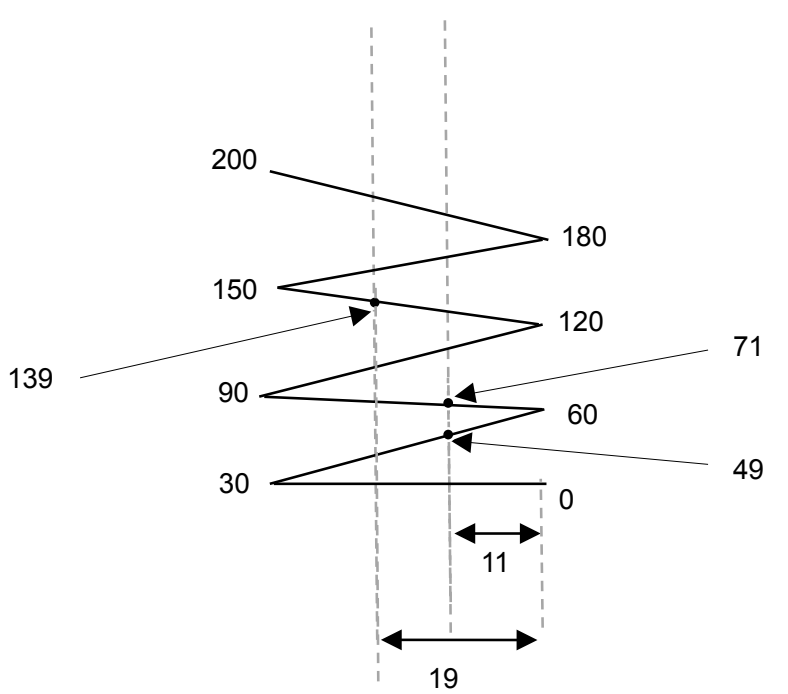

$E$ vemos que também este caso também não ocorre.

Finalmente, se o tamanho de cada pedaço fosse igual a 60, teríamos a seguinte situação:

Este último caso também não ocorre.

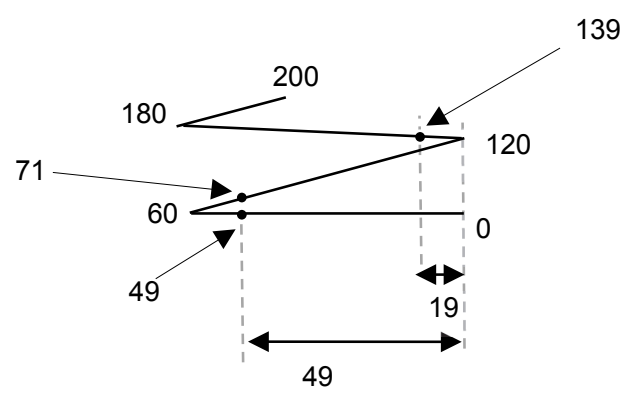

Logo o comprimento de cada pedaço é $15 \mathrm{~cm}$ e a última dobra é feita na marca 195; assim a marca 200 alinha-se com a marca 190, a qual está no penúltimo pedaço. 
ANEXO D - Respostas ao Questionário 


\section{Respostas para o questionário encaminhado à coordenação de elaboração dos itens da prova da primeira fase daOBMEP 2014.}

\section{1- Se há uma matriz de referência para elaboração das questões?}

Inicialmente vale lembrar que a OBMEP é bem mais do que uma olimpíada feita por desafios apresentados na forma de questões para a posterior seleção de medalhistas. Trata-se de um programa arquitetado em rede, com o sério intuito de melhorar o ensino da Matemática nas escolas públicas brasileiras. Destacam-se a enorme capilaridade -feita por meio de uma logística ímpar talvez nunca antes conseguida, mesmo em países mais desenvolvidos que o Brasil - e o impacto na formação de alunos e professores.(sugiro consultar as atividades presentes no site da OBMEP).

Como devem saber, os objetivos da OBMEP são os seguintes:

- Estimular e promover o estudo da Matemática entre alunos das escolas públicas.

- Contribuir para a melhoria da qualidade da Educação Básica.

- Identificar jovens talentos e incentivar seu ingresso nas áreas científicas e tecnológicas.

- Incentivar o aperfeiçoamento dos professores das escolas públicas, contribuindo para a sua valorização profissional.

- Contribuir para a integração das escolas públicas com as universidades públicas, os institutos de pesquisa e as sociedades científicas.

- Promover a inclusão social por meio da difusão do conhecimento.

Quanto ao trabalho do Comitê de Provas, apresento, a seguir, algumas informações que podem ser de interesse na dissertação que estão realizando.

A metodologia de trabalho do Comitê de Provas da OBMEP é bastante diferente de outras avaliações em larga escala realizadas no Brasil. Em uma visão macro, a OBMEP segue rigorosamente os Parâmetros Curriculares Nacionais, segundo a seguinte divisão:

Nível 1: as questões referem-se aos conteúdos tradicionais do Ensino Fundamental I ( $1^{\circ}$. ao $5^{\circ}$. anos). Esta prova é feita por alunos dos $6^{\circ}$.. e $7^{\circ}$. anos

Nível 2: as questões referem-se aos conteúdos tradicionais do Ensino Fundamental I e também dos $6^{\circ}$. . Esta prova é feita por alunos dos $8^{\circ} .$. e $9^{\circ}$. anos

Nível 3: as questões referem-se aos conteúdos tradicionais do Ensino Fundamental I e II ( $1^{\circ}$. ao 9.0 anos). Esta prova é feita por alunos do Ensino Médio.

A OBMEP é dividida em duas fases, a primeira com questões de múltipla escolha aplicadas nas escolas pelos professores, como instrumento de seleção para os alunos que realizarão a segunda fase e a segunda fase é feita em centros de aplicação com provas formadas por seis questões discursivas.

Mais especificamente, no que se refere aos conteúdos específicos são consultados os Guias Curriculares dos Estados Brasileiros, atentando para não levar em consideração as diferenças regionais, mas sim o corpo de conhecimentos adequados ao exercício consciente da cidadania, correspondentes a cada faixa etária. Em outras palavras, os conhecimentos avaliados nas provas da OBMEP são os mesmos que constam nos livros didáticos aprovados pelo PNLD; entretanto as questões das provas intencionalmente não são livrescas, exigindo criatividade e inovação, com ênfase no raciocínio e na capacidade de entender e tratar situações, e não na repetição mecânica de procedimentos.

\section{2- Se é possível termos acesso a essa matriz de referência?}

Sim, basta consultar os documentos oficiais que regem a Educação Brasileira (PCN's e Guias Curriculares oficiais dos estados)

\section{3- Como são utilizados os itens de ligação que estão presentes nos três níveis da OBMEP?}

A confecção da prova é feita por um grupo de 10 pessoas, o qual, trabalhando a distância, constroem, ano a ano, um banco de questões sobre os variados conteúdos de Matemática (Geometria, Álgebra, Aritmética, Funções, Contagem, Probabilidade, Tratamento da Informação) e com os mais variados níveis de dificuldade. O grupo se reúne periodicamente para depurar este banco, classificar as questões por nível e dificuldade e apresentar propostas de provas que são discutidas por todos e também por membros externos para que, artesanalmente sejam apresentadas as versões finais para o envio às escolas ou aos centros de aplicação. O processo todo é contínuo e demora em torno de 8 a 10 meses para ser concluído.

Este trabalho todo deixa muito claro ao final quais são os itens de ligação entre os vários níveis. Evidentemente certos conteúdos não podem ser usados pois são específicos de um determinado nível. 
Os membros do Comitê de Provas são profissionais experientes que trabalham ha muitos anos com alunos e professores da escola básica. Os níveis de dificuldade são apontados pelos participantes e discutidos coletivamente. Muitas vezes não há concordâncias plenas; quando isto ocorre a questão é novamente avaliada, levando-se em conta os pré-requisitos e as dificuldades comumente apresentadas pelos alunos na resolução de problemas. Por exemplo, é fato conhecido que a área de Geometria é pouquíssima trabalhada nas escolas, o que faz com que questões aparentemente simples apresentem-se aos alunos como extremamente difíceis.

\section{5- Se já foram computados os dados da RAIG? Se é possível disponibilizá-los?}

Sim, a coordenação está providenciando as informações.

\section{6- Como são construídos os distratores de cada item?}

A metodologia utilizada na OBMEP é diferente da do ENEM ou de outros testes TRI. Intencionalmente não são colocados distratores nas questões de múltipla escolha da primeira fase. $O$ comitê de provas é atento para evitar distratores, exceto em ocasiões muito raras e especiais. Evita-se, a todo custo, canalizar o aluno a respostas que não sejam as corretas ou que sejam atraídos por interpretações não presentes nos enunciados

\section{7- Se há incentivo de uso de itens inéditos?}

Total. Partimos sempre com a expectativa de fazer uma prova com questões inéditas, ou mesmo com situações inovadoras construídas a partir de situações já conhecidas. Uma análise feita nas provas anteriores deve mostrar a grande variedade de situações novas presentes nas questões.

\section{8- Se há normas de construção dos itens?}

Inicialmente não. Mas há padrão que vem sendo construído ao logo dos anos, que posso chamar orgulhosamente de padrão OBMEP. São questões com enunciado claro e curto, inspiradoras. Acreditamos que as questões da OBMEP constituem um instrumento precioso para incentivar os alunos com gosto pela matemática, aflorando suas aptidões, inclusive para aqueles que não se destacam nas tradicionais avaliações escolares.

\section{9- Se os itens são apenas desafiadores ou há pré-estabelecimento de avaliação de competências ou habilidades em cada item?}

Não há pré-estabelecimentos, exceto os impostos pelos pré-requisitos que o aluno deve ter nas suas diferentes faixas etárias. Há bastante preocupação em não confeccionar provas concentradas em uma única área da Matemática, mas sim a tentativa de contemplar todas elas. As questões não são avaliadas apenas individualmente, elas também devem coexistir de maneira coerente com as demais. 



\section{Índice}

$P_{I N F}, 61$

$P_{I N T}, 61$

$P_{S U P}, 61$

ação errônea, 91

acerto ao acaso, 58

AGI, 63

ambiente construtivista, 66

Análise de Conteúdo, 81

análise de erros, 87

auto-monitoramento, 45

autonomia, 88

avaliação

classificatória, 44

em larga escala, 48

formal, 46

formativa, 45

informal, 46

institucional, 48

para aprendizagem, 47

somativa, 44

categorização, 83

classificação de erros, 95

coeficientes bisseriais, 62

comando, 73

competências, 70

conflito cognitivo, 90

constituição do corpus, 82

construção do conhecimento, 90

construtivismo, 90

contextualização, 65

correlação bisserial, 62

dado construto, 59

DCN, 65

dificuldade dos itens, 60 discriminação, 58

discriminação dos itens, 60

distratores, 75

Educação Matemática Crítica, 40

ENEM, 57

enfoque

epistemológico, 98

pedagógico, 98

psicológico, 98

enfoques do erro, 98

erro, 87

erros

de adequação, 95

de aplicações de regras, 95

de associações incorretas, 95

de deficiência de conteúdo, 95

de dificuldade de linguagem, 95

de informação espacial, 95

de lógica, 95

de saber, 95

de saber-fazer, 95

escore bruto, 60

exploração do material, 82

formatos de itens

certo ou errado, 68

dissertativo, 68

múltipla escolha, 67

resposta curta aberta, 68

resposta fechada, 68

formulação de hipóteses, 82

gabarito, 76

habilidade, 70

IMO, 30 
IMPA, 32

IMU, 34

independência local, 57

inferência, 81

item, 67

itens convencionais, 65

LDB, 47

leitura flutuante, 82

medir, 49

níveis de resposta, 91

NUMERATIZAR, 35

OBM, 32

OBMEP, 34

obstáculo, 93

obstáculos

de origem didática, 93

de origem ontogenética, 93

epistemológicos, 93

OIAM, 30

patamares do erro, 95

PCN, 47

peguinha, 75

percentual de acerto, 61

PISA, 40

plausibilidade, 85

PPP, 47

pré-análise, 82

pré-testagem, 78

proficiência, 58

prova, 67

Prova Brasil, 48

prova escrita, 52

referenciação dos índices, 82

Saeb, 48

SBM, 32

SINAES, 48 situações-problema, 53

TCT, 59

Teoria Clássica dos Testes, 59

Teoria de Resposta ao Item, 57

texto-base, 72

textualização, 65

tratamento dos resultados, 83

TRI, 57

unidimensionalidade, 57 